\title{
Characterization and Simulation of Flow in the Lower Arkansas River Alluvial Aquifer, South-Central Kansas
}

By Xiaodong Jian, Lanna J. Combs, and Cristi V. Hansen

Prepared in cooperation with the

KANSAS DEPARTMENT OFAGRICULTURE,

DIVISION OFWATER RESOURCES

Scientific Investigations Report 2004-5204

U.S. Department of the Interior

U.S. Geological Survey 


\title{
U.S. Department of the Interior Gale A. Norton, Secretary
}

\author{
U.S. Geological Survey \\ Charles G. Groat, Director
}

\section{U.S. Geological Survey, Reston, Virginia: 2004}

\author{
For sale by U.S. Geological Survey, Information Services \\ Box 25286, Denver Federal Center \\ Denver, CO 80225 \\ For more information about the USGS and its products: \\ Telephone: 1-888-ASK-USGS \\ World Wide Web: http://www.usgs.gov/
}

Any use of trade, product, or firm names in this publication is for descriptive purposes only and does not imply endorsement by the U.S. Government.

Although this report is in the public domain, permission must be secured from the individual copyright owners to reproduce any copyrighted materials contained within this report.

Suggested citation:

Jian, Xiaodong, Combs, L.J., and Hansen, C.V., 2004, Characterization and simulation of flow in the lower Kansas River alluvial aquifer, south-central Kansas: U.S. Geological Survey Scientific Investigations Report 2004-5204, 82 p. 


\section{Contents}

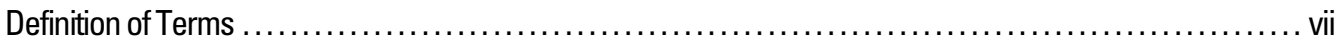

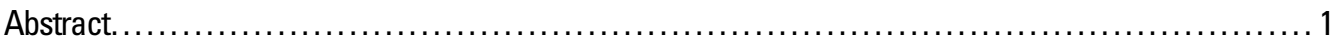

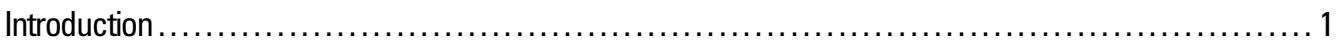

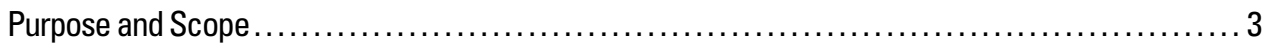

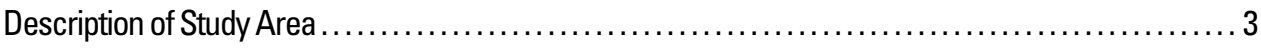

Well and Surface-Water Site-Identification Systems. ................................. 3

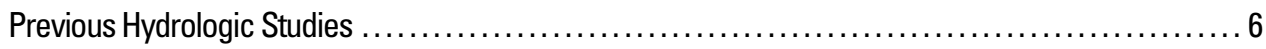

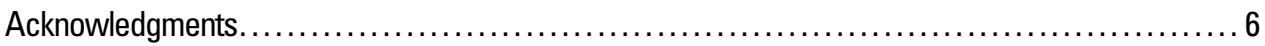

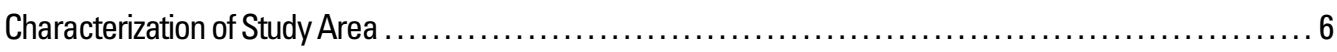

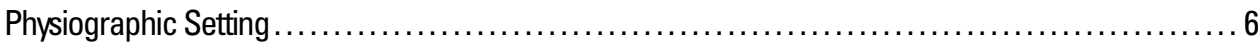

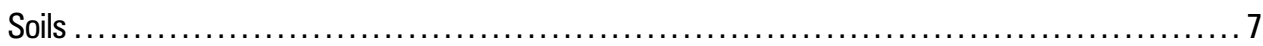

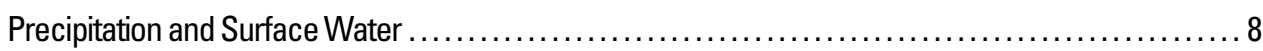

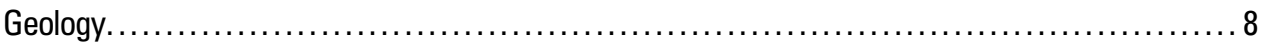

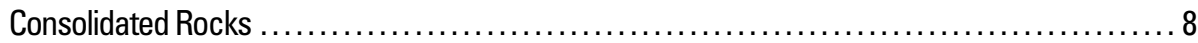

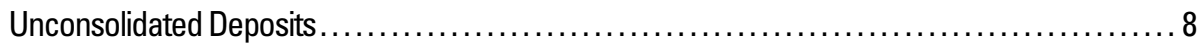

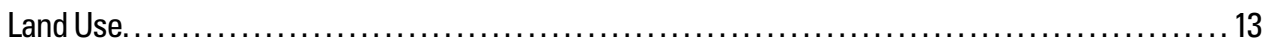

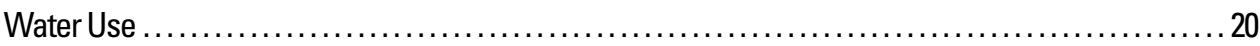

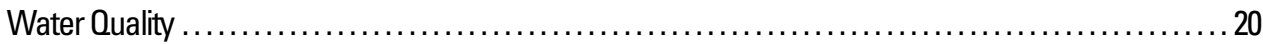

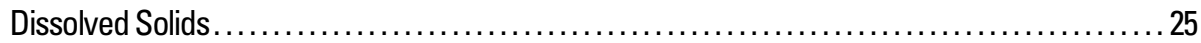

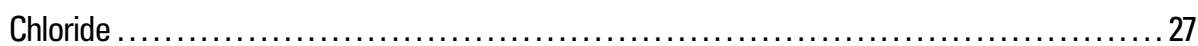

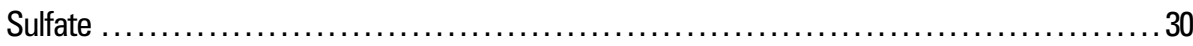

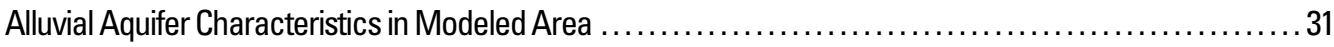

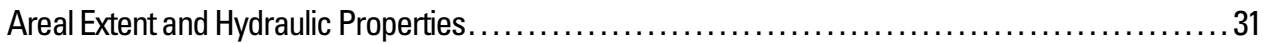

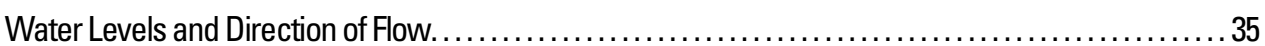

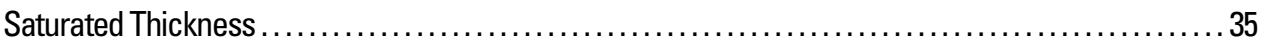

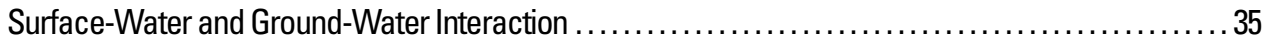

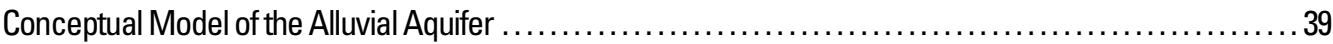

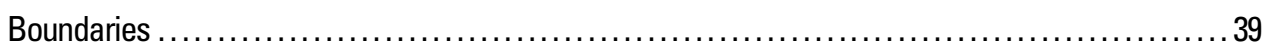

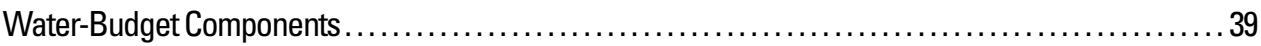

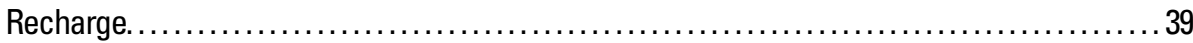

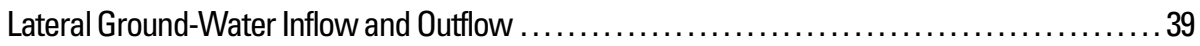

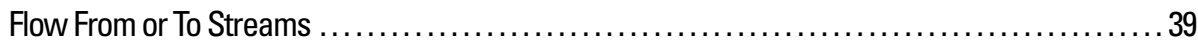

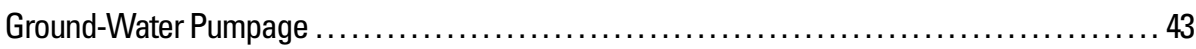

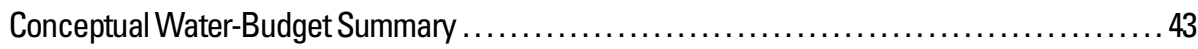

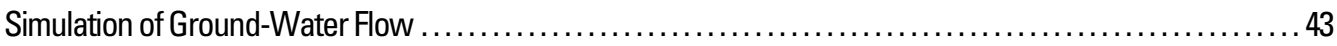

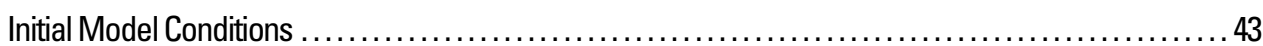

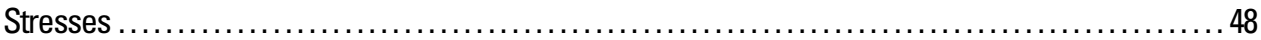

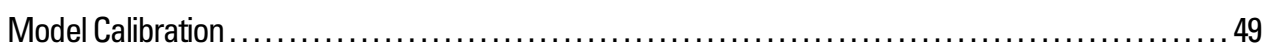

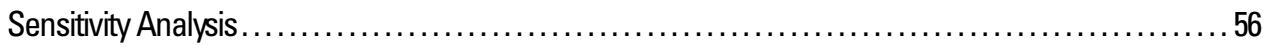

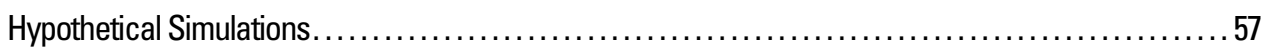

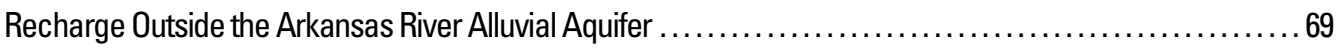

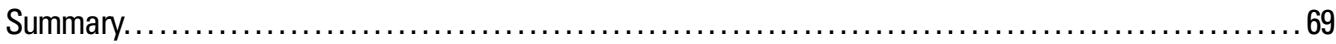

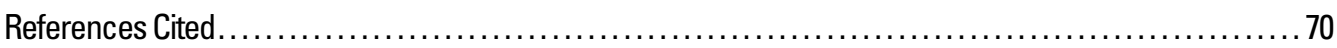


Supplemental Information

\section{Figures}

1. Maps showing location of study area and lower Arkansas, Ninnescah, and Walnut River Basins

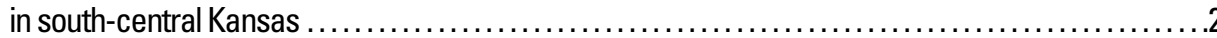

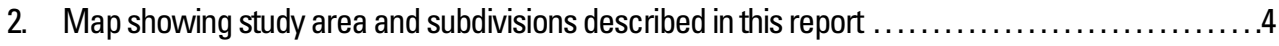

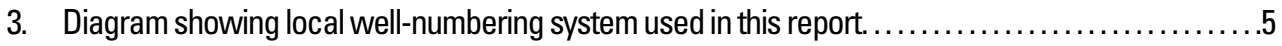

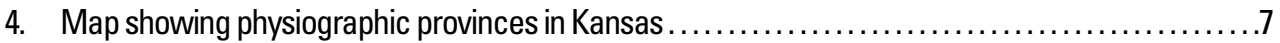

5. Map showing areas of equal mean soil permeability in study area $\ldots \ldots \ldots \ldots \ldots \ldots \ldots \ldots \ldots \ldots$

6. Graphs showing average minimum and maximum monthly temperatures and average monthly precipitation at Arkansas City, El Dorado, Wellington, Wichita, and Winfield.................. 10

7. Graphs showing total annual and normal precipitation at Arkansas City, El Dorado,

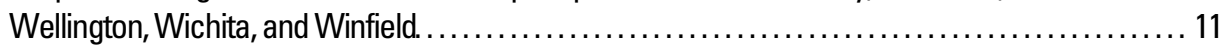

8-10. Maps showing:

8. Location of currently active U.S. Geological Survey gaging stations in study area and sites where miscellaneous streamflow measurements were made, $2001-03 \ldots \ldots \ldots \ldots \ldots \ldots \ldots \ldots$

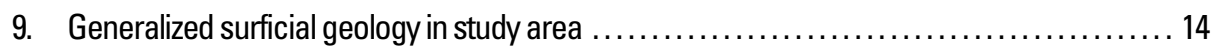

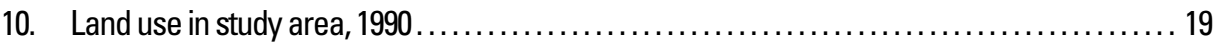

11. Pie diagrams showing percentages of water withdrawn from study area, 1990, 1995, and $2000 \ldots 24$

12-18. Maps showing:

12. Location of ground- and surface-water sites where water-quality samples were collected during August 2003 in and near modeled area ............................... 26

13. Historical dissolved-solids concentrations in water from wells in the four-county study area and dissolved-solids concentrations in ground- and surface-water samples collected from modeled area, August 2003.

14. Historical chloride concentrations in water from wells in the four-county study area and chloride concentrations in ground- and surface-water samples collected from modeled area, August 2003

15. Location of past and present oil and gas fields in the four-county study area and wells with chloride concentrations in water samples equal to or greater than 500 milligrams per

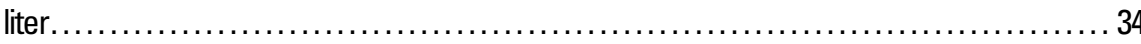

16. Historical sulfate concentrations in water from wells in the four-county study area and sulfate concentrations in ground- and surface-water samples collected from modeled

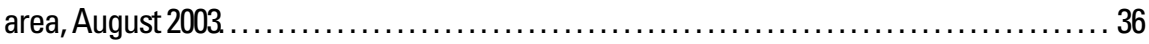

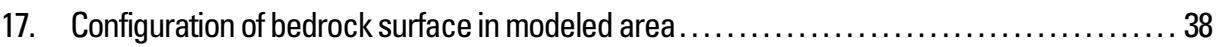

18. Water-level altitudes and approximate direction of ground-water flow in alluvial aquifer in modeled area, March 2001 and February 2002

19. Graphs showing ground-water levels in representative observation well in study area and annual precipitation at nearby Wichita, 1962-2003

20. Maps showing approximate saturated thickness of the alluvial aquifer in the modeled area, March 2001 and February 2002

21-23. Graphs showing:

21. Daily mean river-stage altitude of Little Arkansas River at Valley Center, daily mean water-level altitude in nearby well, and daily precipitation at streamflow-gaging station, August 2002-

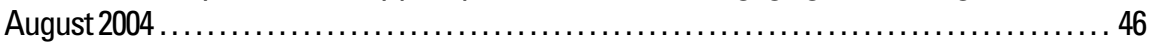

22. Monthly instantaneous ground-water levels in wells EB-216-AA, EB-216-A, EB-216-B, EB-216-C and the mean daily river stage of the Arkansas River near Hutchinson, April 1988May 1990. 
23. Duration curve of estimated streamflow gains for Arkansas River between Wichita and

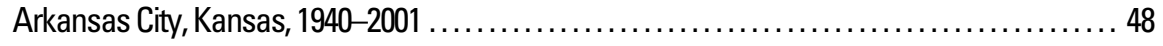

24-29. Maps showing:

24. Finite-difference grid and boundary conditions used in model analyses............... 50

25. Distribution of average volume of ground-water withdrawals from modeled area reported

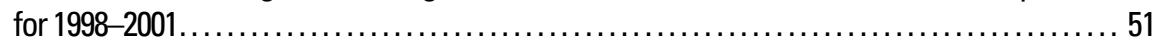

26. Calibrated ground-water recharge rates for modeled area ....................... 52

27. Distribution of horizontal hydraulic conductivity in modeled area .................... 53

28. Simulated saturated thickness of alluvial aquifer in modeled area with average reported

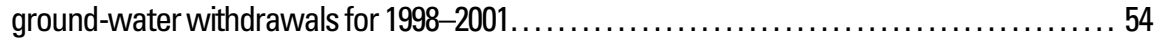

29. Comparison of measured water-level altitudes for March 2001 and simulated water-level altitudes with average reported ground-water withdrawals for $1998-2001 \ldots \ldots \ldots \ldots \ldots 55$

30. Graph showing differences between measured and simulated water-level altitudes,

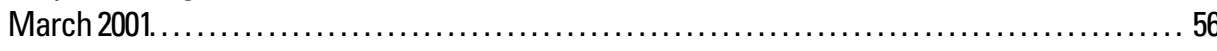

31. Graphs showing mean deviations of simulated hydraulic heads from accepted modelcalibration heads for changes in streambed conductance, recharge, and hydraulic conductivity. . 57

32. Maps showing simulated saturated thickness of alluvial aquifer in modeled area using different pumping scenarios 59

\section{Tables}

1. Drainage area, period of record, and annual median and maximum peak discharge for period of record at 14 currently active U.S. Geological Survey gaging stations in Butler, Cowley, Sedgwick, and Sumner Counties, south-central Kansas...................................... 13

2. Generalized geohydrologic section for Butler, Cowley, Sedgwick, and Sumner Counties, south-

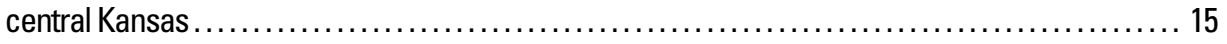

3. Land use in Butler, Cowley, Sedgwick, and Sumner Counties, south-central Kansas, 1990 . ...... 20

4. Estimated water use in Butler, Cowley, Sedgwick, and Sumner Counties, south-central Kansas,

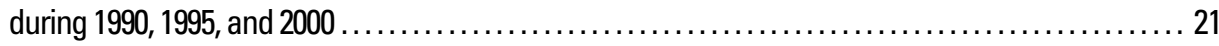

5. Reported ground-water use in modeled area of lower Arkansas River Basin in south-central

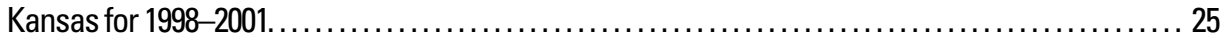

6. Estimated net streamflow gain in modeled area of lower Arkansas River Basin, south-central

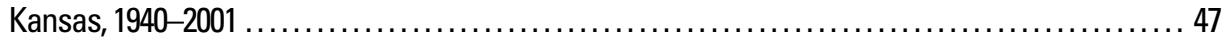

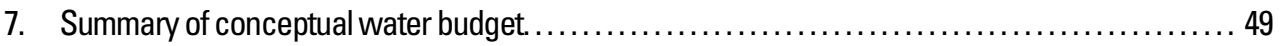

8. Simulated steady-state water budget for Arkansas River alluvial aquifer in modeled area, Cowley, Sedgwick, and Sumner Counties, south-central Kansas ....................... 56

9. Simulated steady-state water budgets used in hypothetical simulations of alluvial aquifer in

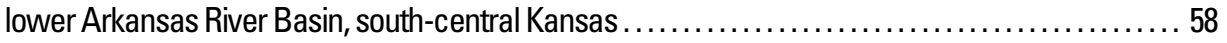

10. Estimated recharge rates in upland contributing-drainage areas, Butler, Harvey, Marion, Sedgwick, and Sumner Counties, south-central Kansas.

11. Results of water-quality analyses of samples collected during August 2003 from ground- and surface-water sites in Cowley, Sedgwick, and Sumner Counties, south-central Kansas.

12. Records of wells where water levels were measured during March 2001 and February 2002 in alluvial deposits in modeled area of Cowley, Sedgwick, and Sumner Counties, south-central Kansas. . . . 78

13. Results of miscellaneous streamflow measurements made in March 2001, February 2002, and August 2003 in modeled area of lower Arkansas River Basin, south-central Kansas. 


\section{Conversion Factors, Abbreviations, and Datums}

\begin{tabular}{|c|c|c|}
\hline Multiply & By & To obtain \\
\hline acre & 4,047 & square meter $\left(\mathrm{m}^{2}\right)$ \\
\hline acre-foot (acre-ft) & 1,233 & cubic meter $\left(\mathrm{m}^{3}\right)$ \\
\hline acre-foot per year (acre-ft/yr) & 1,233 & cubic meter per year $\left(\mathrm{m}^{3} / \mathrm{yr}\right)$ \\
\hline cubic foot per second $\left(\mathrm{ft}^{3} / \mathrm{s}\right)$ & 0.02832 & cubic meter per second $\left(\mathrm{m}^{3} / \mathrm{s}\right)$ \\
\hline cubic foot per second $\left(\mathrm{ft}^{3} / \mathrm{s}\right)$ & 0.6463 & million gallons per day (Mgal/d) \\
\hline cubic foot per second per year & & cubic meter per second per year \\
\hline$\left[\left(\mathrm{ft}^{3} / \mathrm{s}\right) / \mathrm{yr}\right]$ & 0.02832 & {$\left[\left(\mathrm{~m}^{3} / \mathrm{s}\right) / \mathrm{yr}\right]$} \\
\hline $\begin{array}{l}\text { cubic foot per second per year } \\
{\left[\left(\mathrm{ft}^{3} / \mathrm{s}\right) / \mathrm{yr}\right]}\end{array}$ & 724 & $\begin{array}{l}\text { acre-foot per year per year } \\
{[(\text { acre-ft/yr }) / \mathrm{yr}]}\end{array}$ \\
\hline degree Fahrenheit $\left({ }^{\circ} \mathrm{F}\right)$ & (1) & degree Celsius $\left({ }^{\circ} \mathrm{C}\right)$ \\
\hline foot $(\mathrm{ft})$ & 0.3048 & meter $(\mathrm{m})$ \\
\hline foot per day (ft/d) & 0.3048 & meter per day $(\mathrm{m} / \mathrm{d})$ \\
\hline foot squared per day $\left(\mathrm{ft}^{2} / \mathrm{d}\right)$ & 0.09290 & meter squared per day $\left(\mathrm{m}^{2} / \mathrm{d}\right)$ \\
\hline gallon per day (gal/d)) & 3.785 & liter per day $(\mathrm{L} / \mathrm{d})$ \\
\hline gallon per minute (gal/min) & 0.06309 & liter per second $(\mathrm{L} / \mathrm{s})$ \\
\hline inch (in.) & 2.54 & centimeter $(\mathrm{cm})$ \\
\hline inch per day (in/d) & 2.54 & centimeter per day $(\mathrm{cm} / \mathrm{d})$ \\
\hline inch per hour (in/hr) & 2.54 & centimeter per hour $(\mathrm{cm} / \mathrm{hr})$ \\
\hline inch per year (in/yr) & 2.54 & centimeter per year $(\mathrm{cm} / \mathrm{yr})$ \\
\hline microgram per liter $(\mu \mathrm{g} / \mathrm{L})$ & 1.0 & part per billion (ppb) \\
\hline mile (mi) & 1.609 & kilometer $(\mathrm{km})$ \\
\hline milligram per liter (mg/L) & (2) & part per million (ppm) \\
\hline million gallons per day $(\mathrm{Mgal} / \mathrm{d})$ & 0.04381 & cubic meter per second $\left(\mathrm{m}^{3} / \mathrm{s}\right)$ \\
\hline million gallons per day (Mgal/d) & 1,120 & acre-foot per year $[($ acre-ft $) / y r]$ \\
\hline square foot $\left(\mathrm{ft}^{2}\right)$ & 0.09290 & square meter $\left(\mathrm{m}^{2}\right)$ \\
\hline square mile $\left(\mathrm{mi}^{2}\right)$ & 2.590 & square kilometer $\left(\mathrm{km}^{2}\right)$ \\
\hline
\end{tabular}

${ }^{1}$ Temperature can be converted to degrees Celsius $\left({ }^{\circ} \mathrm{C}\right)$ or degrees Fahrenheit $\left({ }^{0} \mathrm{~F}\right)$ by the equations:

$$
\begin{aligned}
& { }^{0} \mathrm{C}=5 / 9\left({ }^{\circ} \mathrm{F}-32\right) \\
& { }^{0} \mathrm{~F}=9 / 5\left({ }^{\circ} \mathrm{C}\right)+32 .
\end{aligned}
$$

${ }^{2}$ For concentrations less than $7,000 \mathrm{mg} / \mathrm{L}$, the numerical value is the same as for concentrations in parts per million.

Abbreviated water-quality units used in this report: Chemical concentrations are given in metric units. Chemical concentration is given in milligrams per liter $(\mathrm{mg} / \mathrm{L})$, in micrograms per liter $(\mu \mathrm{g} / \mathrm{L})$, or microsiemens per centimeter at 25 degrees Celsius $(\mu \mathrm{S} / \mathrm{cm})$. Milligrams per liter is a unit expressing the concentration of chemical constituents in solution as weight (milligrams) of solute per unit volume (liter) of water. Micrograms per liter is a unit expressing the concentration of chemical constituents in solution as weight (micrograms) of solute per unit volume (liter) of water.

Datums: Horizontal coordinate information is referenced to the North American Datum of 1983 (NAD 83). Vertical coordinate information is referenced to the North American Vertical Datum of 1988 (NAVD 88). 


\section{Definition of Terms}

\section{alluvium (alluvial sediment deposits)}

Deposits of clay, silt, sand, gravel, or other particular rock material left by a river in a streambed, on a flood plain, delta, or at the base of a mountain.

aquifer A geologic formation, group of formations, or part of a formation that contains sufficient saturated permeable material to yield significant quantities of water to wells or springs.

arkosic Having wholly or in part the character of arkose-sandstone of granular texture, composed primarily of angular to subangular grains of quartz and feldspar.

base flow Sustained or fair weather flow in a stream. Base flow is composed largely of ground-water discharge to the stream.

colluvium A general term applied to any loose, heterogeneous, and incoherent mass of soil material or rock fragments deposited by unconcentrated surface runoff, usually at the base of a slope.

discharge As a surface-water term refers to the volume of water that passes through a cross section of a stream channel per unit of time as measured in cubic feet per second. As a ground-water term refers to the process involved in the outflow of water from the saturated part of an aquifer as measured in inches or acre-feet.

gage height Is the water-surface elevation above the gage datum. Gage datum is a horizontal surface used as a zero point for measurement of stream stage. This surface usually is located slightly below the lowest point of the stream bottom. If the elevation of the gage datum relative to the national datum (NAVD 88) has been determined, then the gage readings can be converted to elevations above the national datum by adding the elevation of the gage datum to the gageheight reading. hydraulic conductivity The volume of water at the existing kinematic viscosity that will move in unit time under a unit hydraulic gradient through a unit area measured at right angles to the direction of flow. The standard unit for hydraulic conductivity is cubic foot per day per square foot $\left[\left(\mathrm{ft}^{3} / \mathrm{d}\right) / \mathrm{ft}^{2}\right]$. This mathematical expression reduces to foot per day $(\mathrm{ft} / \mathrm{d})$.

hydraulic gradient [dimensionless] Change in total hydraulic head per unit of distance in a given direction.

hydraulic head Height above a standard datum (such as NAVD 88) of the surface of a water column that can be supported by the static water pressure at a given point in an aquifer.

permeability A measure of the relative ease with which a porous medium can transmit a liquid under a potential gradient. It is a property of the medium that is dependent upon the number, shape, and size of the pores (void spaces).

porosity [dimensionless] The ratio of the volume of void spaces in sediment or rock to the total volume of the sediment or rock.

potentiometric divide A ridge in the water table (potentiometric surface) from which the ground water represented by that surface moves away in both directions.

recharge The process involved in the addition of water to the saturated part of an aquifer.

saturated thickness The thickness of the zone in an aquifer that is saturated with water.

soil permeability The quality of the soil to transmit water as measured in inches per hour.

specific capacity The rate of discharge of water from a well divided by the drawdown of the water level in the well.

specific storage Volume of water that an aquifer releases from or takes into aquifer storage per unit volume of saturated aquifer material per unit change in hydraulic head. 
specific yield The ratio of the volume of water that sediment or rock, after being saturated, will yield by gravity to the total volume of the rock or sediment.

steady state Condition under which there are no changes in aquifer storage, the magnitude and direction of ground-water flow velocities are constant with time, and water inflow to and outflow from the aquifer are equal and constant.

storage coefficient Volume of water that an aquifer releases from or takes into aquifer storage per unit surface area per unit change in hydraulic head.

streambed conductance A measure of the ability of a streambed to transmit water, reported in feet squared per day.

stream stage The height of water surface in the stream above an established datum. transmissivity The capacity of an aquifer to transmit water of the prevailing kinematic viscosity is referred to as its transmissivity. The transmissivity $(T)$ of an aquifer is equal to the hydraulic conductivity of the aquifer multiplied by the saturated thickness of the aquifer, generally expressed in feet squared per day $\left(\mathrm{ft}^{2} / \mathrm{d}\right)$ (Heath, 1987, p. 26).

water table The surface in an unconfined ground-water body where water pressure is equal to atmospheric pressure. It is defined by the levels at which water stands in wells that penetrate the water body just far enough to hold standing water.

water year Water year is the 12-month period beginning October 1 and ending September 30 . Water years are designated by the year in which they end; for example, the 12-month period beginning October 1, 2001, and ending September 30, 2002, is called the " 2002 water year." 


\title{
Characterization and Simulation of Flow in the Lower Arkansas River Alluvial Aquifer, South-Central Kansas
}

\author{
By Xiaodong Jian, Lanna J. Combs, and Cristi V. Hansen
}

\section{Abstract}

Large parts of the lower Arkansas, Ninnescah, and Walnut River Basins in south-central Kansas - an area that includes Wichita, the largest city in Kansas_-are experiencing rapid population growth and, consequently, increasing demands on surface- and ground-water resources in addition to agricultural irrigation in the area. The quantity and quality of water available in the lower Arkansas, Ninnescah, and Walnut River Basins in Butler, Cowley, Sedgwick, and Sumner Counties are crucial as population and water use continue to increase in the region.

A steady-state model was constructed to simulate flow in the Arkansas River alluvial aquifer between Wichita and Arkansas City. Calibration was achieved using March 2001 measured water levels and streamflow gain using long-term (1940-2001) streamflow records. Average recharge about 5 inches per year; average aquifer hydraulic conductivity was about 500 feet per day; well pumpage (average of reported 1998-2001 use) was 56 cubic feet per second; and net flow from the alluvial aquifer to streams in the modeled area was computed by hydrograph separation to be 157 cubic feet per second.

Nine hypothetical simulations were conducted with ground-water pumpage varying from zero to double authorized pumpage (206 cubic feet per second). Net remaining aquifer thickness declined for the largest simulated pumpage increases in comparison to 1998-2001 average pumping, as did flow from the aquifer to the Arkansas River. Simulated aquifer thickness decreases were more pronounced in areas where pumpage is currently (2004) greatest.

\section{Introduction}

Parts of the lower Arkansas, Ninnescah, and Walnut River Basins in south-central Kansas - an area that includes Wichita, the largest city in Kansas (fig. 1)-are experiencing rapid population growth and, consequently, increasing demands on surface- and ground-water resources for public-supply water use. The quantity and quality of water available in the lower Arkansas, Ninnescah, and Walnut River Basins in the four-county area of Butler, Cowley, Sedgwick, and Sumner Counties are crucial as population and water use continue to increase.
Population and public-supply water use in the four-county area increased by about 11 and 24 percent, respectively, between 1990 and 2000. The population was about 517,000 in 1990 (U.S. Census Bureau, 1995) and 575,000 in 2000 (Institute for Public Policy and Business Research, 2002). Total public-supply water use was $57.88 \mathrm{Mgal} / \mathrm{d}$ in 1990 and $71.53 \mathrm{Mgal} / \mathrm{d}$ in 2000 (U.S. Geological Survey, 2003). The Institute for Public Policy and Business Research (2003) projects another 6-percent increase in population between 2000 and 2010 (projection of 612,000 people), with much of this increase occurring in Sedgwick County. Growth concerns and associated stress on water resources are of particular concern south of Wichita.

The Kansas Department of Agriculture, Division of Water Resources (DWR), is charged with the beneficial allocation of water resources in Kansas and is concerned about the increase and projected demands on the limited water resources available in the lower Arkansas, Ninnescah, and Walnut River Basins. Important ongoing concerns include (Kansas Water Office, 2002):

- Sufficient water supplies to meet projected 2040 public water-supply needs - outside of the river valleys, there are no widespread, large-yielding sources of fresh ground water in the four-county area. Groundwater resources, while not adequate in most areas for large users such as public water supplies, typically have been adequate during most climatic conditions for the demands of domestic-supply wells. However, during a severe drought the ground-water resources will likely be inadequate in some parts of the area even for these small demands. Shortages also may occur if water demands increase due to increases in population or in other sources of demand such as crop watering and new industries.

- Water quality unsuitable for some uses limits the supply of surface water from most streams in the four-county area, especially during periods of low flow_-ground-water supplies are limited locally by large chloride and sulfate concentrations, the sources of which include natural discharge of water from dissolution of salt or gypsum deposits in the underlying bedrock, surface-water transport from areas upstream and within the lower Arkansas, Ninnescah, and Walnut River Basins, and past oilfield-brine disposal practices. 


\section{Characterization and Simulation of Flow in the Lower Arkansas River Alluvial Aquifer, South-Central Kansas}
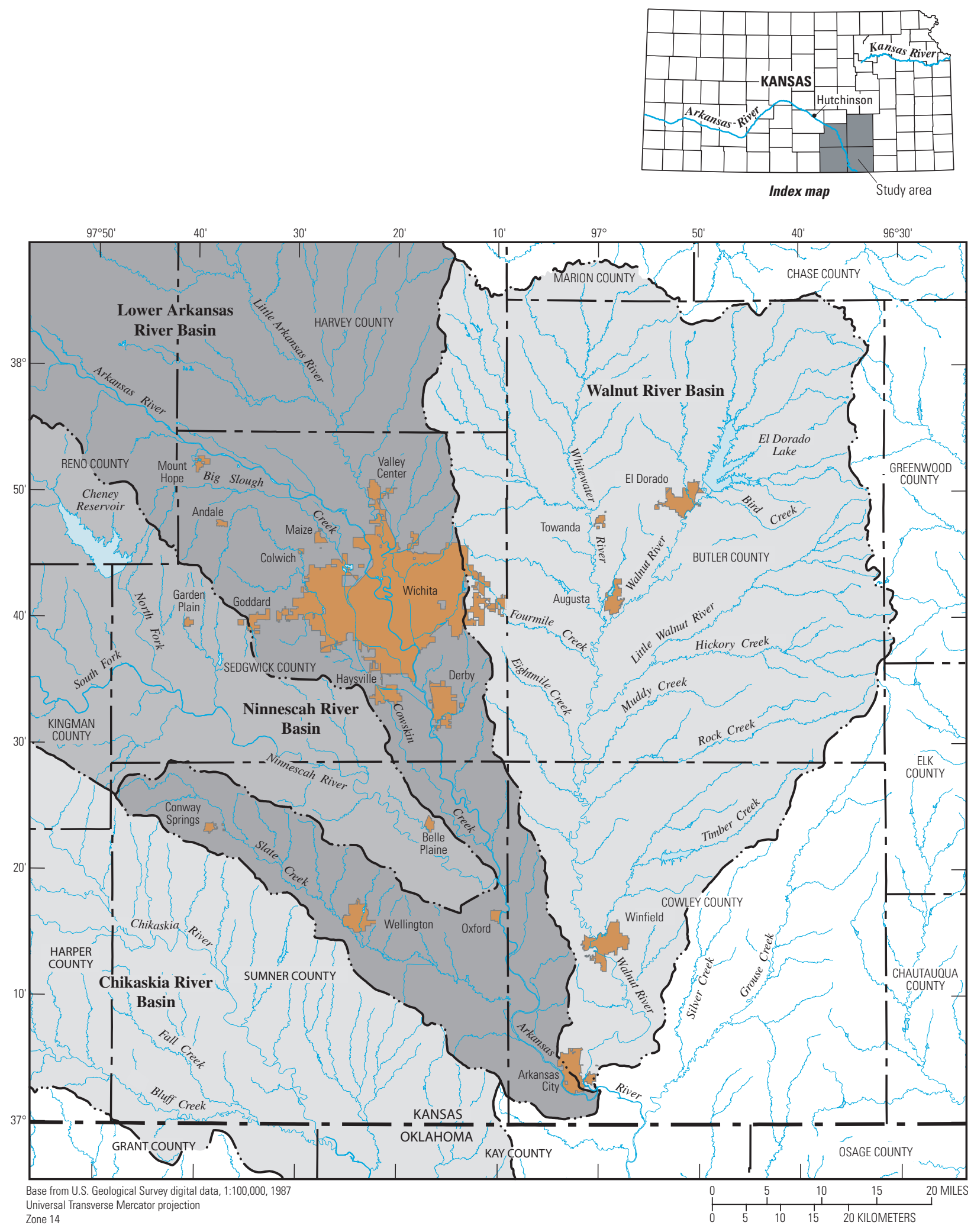

Horizontal coordinate information is referenced to the North American Datum of 1983 (NAD 83)

\section{EXPLANATION}

\section{- - B - Boundary of river basin}

Figure 1. Location of study area and lower Arkansas, Ninnescah, and Walnut River Basins in south-central Kansas. 
- Interaction of surface and ground water can affect the quantity and quality of water available for usefor example, increases in ground-water withdrawals may reduce the amount of surface water available for use or may induce poorer quality water to flow into an aquifer from either overlying surface-water sources or underlying rocks. Gravel pits and other areas where the water table has been exposed may act as both areas of recharge and discharge, depending on the hydrologic and climatic conditions.

- Development pressures in the lower Arkansas River Valley south of Wichita are raising a host of watersupply and water-quality concerns in an area for which there is insufficient hydrologic information with which to effectively manage the available surface- and ground-water resources.

DWR recognized that the hydrologic information available for the area was not sufficient for it to effectively apply existing water-management and regulatory measures to protect and allocate the limited water resources in the lower Arkansas, Ninnescah, and Walnut River Basins, especially during periods of drought. Therefore, in 2000 DWR entered into a cooperative agreement with the U.S. Geological Survey (USGS) (supported in part by the Kansas State Water Plan Fund) to conduct a study to provide an improved understanding of: (1) ground-water flow conditions, (2) surface-water and ground-water interaction, and (3) the effect of varying hydrologic conditions on the availability and quality of surface and ground water in the fourcounty area.

This information will help DWR meet the second of 15 long-range objectives of the Kansas Water Plan approved by the Kansas Water Authority in October 1998 (Kansas Water Authority, 1998) by careful management of existing water resources in the four-county area. The second objective states that "by 2010, less than five percent of public water suppliers will be drought vulnerable." The methods and results of this study also will be applicable to similar study areas nationwide.

\section{Purpose and Scope}

The purposes of this report are to describe:

- the quantity and quality of surface- and ground-water resources in Butler, Cowley, Sedgwick, and Sumner Counties in south-central Kansas with particular emphasis on the Arkansas River Valley from Wichita to just north of Arkansas City;

- areas of poor ground-water quality;

- the development and results of a steady-state numerical model of ground-water flow that DWR will be able to use as a tool to aid in management of the lower Arkansas River alluvial aquifer;

- the effects of various hypothetical well pumping scenarios on surface- and ground-water availability; and
- estimates of recharge from computations of streamflow gain from ground water in two upland areas.

The descriptions and discussions in this report are limited to Butler, Cowley, Sedgwick, and Sumner Counties (study area in fig. 1) and to upland contributing-drainage areas of the Whitewater River that extend into Harvey and Marion Counties.

\section{Description of Study Area}

To meet study objectives and for the purposes of this report, the four-county study area was divided into the modeled area of the Arkansas River Valley and two distinct upland contributing-drainage areas (fig. 2). The modeled area includes only the alluvial deposits in the Arkansas River Valley from the USGS streamflow-gaging station on the Arkansas River near Maize (station 07143375 in Sedgwick County) to the USGS gaging station at Arkansas City (station 07146500 in Cowley County). The two upland contributing-drainage areas are upstream from the USGS gaging station on the Whitewater River at Towanda (station 07147070) in Butler County, extending outside the four-county study area into parts of Harvey and Marion Counties, and upstream from the USGS gaging station on Slate Creek at Wellington (station 07145700) (fig. 2). The upland areas in this report are that part of the four-county study area outside of the alluvial boundary as shown in figure 2 .

\section{Well and Surface-Water Site-Identification Systems}

Each data-collection site in this report, whether a well or stream site, has been assigned a unique identification number. This number is unique in that it applies specifically to a given site indefinitely. The systems used by USGS to assign identification numbers for well and surface-water sites differ, but both are based on geographic location.

Local well numbers are assigned according to a modification of the Bureau of Land Management's system of land subdivision. In this system (fig. 3), the first set of digits in the well number refers to the township north $(\mathrm{N})$ or south $(\mathrm{S})$ of the Kansas-Nebraska State line; the second set refers to the range east (E) or west (W) of the Sixth Principal Meridian; and the third set refers to the section in which the well is located. The terminal letters refer to the 160-acre, 40-acre, 10-acre, and 2.5-acre tracts within the section. The letters A, B, C, or D are assigned in a counterclockwise direction beginning in the northeast quadrant. The final two digits are sequence numbers beginning with 01 . For example, local well number 26S-01W-14CBB-03 indicates the third well inventoried in the northwest quarter of the northwest quarter of the southwest quarter of section 14, township 26 south (S), range 01 west (W) (fig. 3).

Since October 1, 1950, USGS streamflow-gaging stations are assigned an eight-digit number according to downstream order. The first two digits of each station in Kansas are either "06" or " 07, ," which designates the major river basin. 


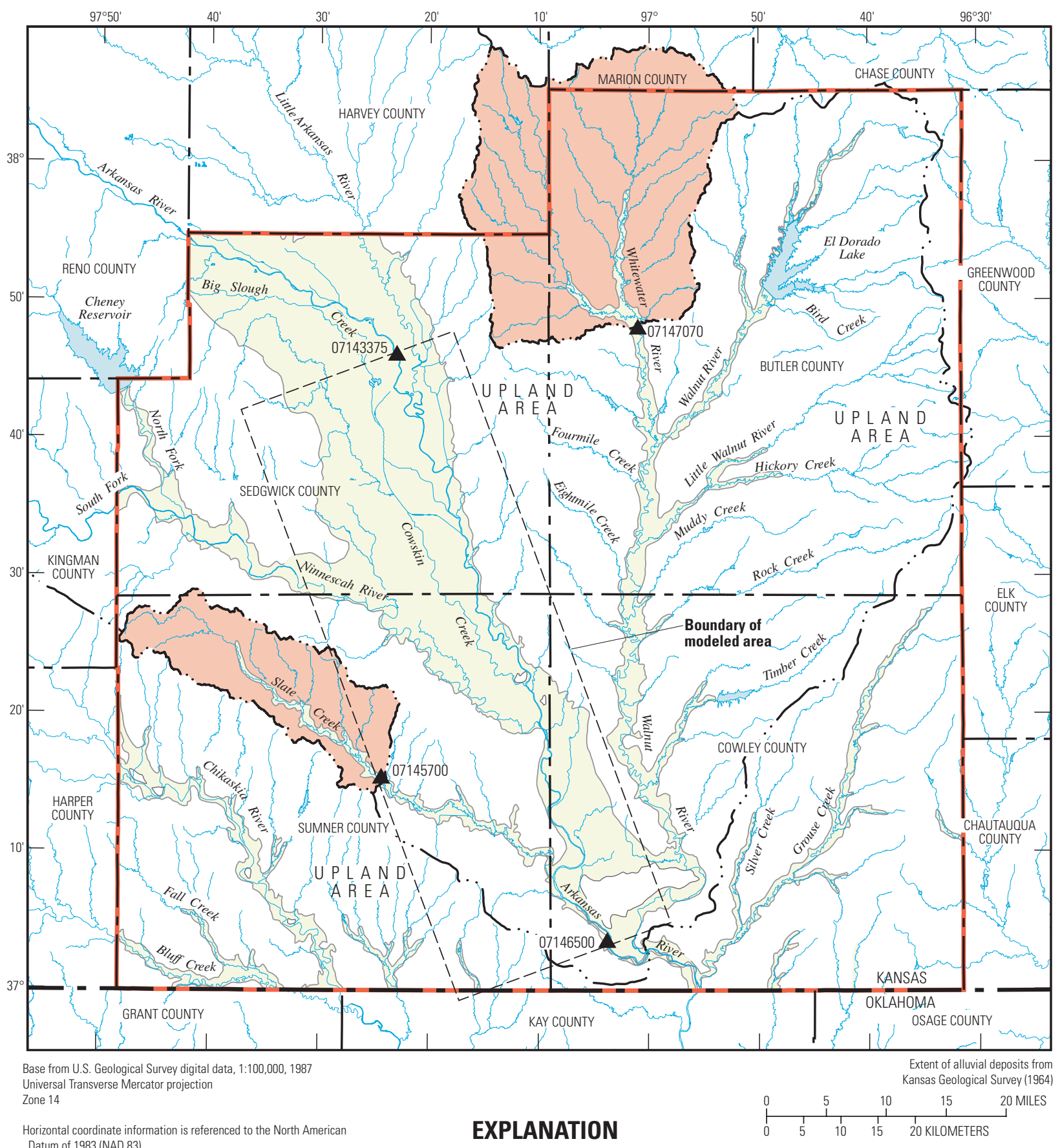

Datum of 1983 (NAD 83)

Alluvial deposits

Upland contributing-drainage area

Boundary of drainage area
Boundary of four-county study area

07146500 U U.S. Geological Survey streamflowgaging station and number

Figure 2. Study area and subdivisions described in this report. 


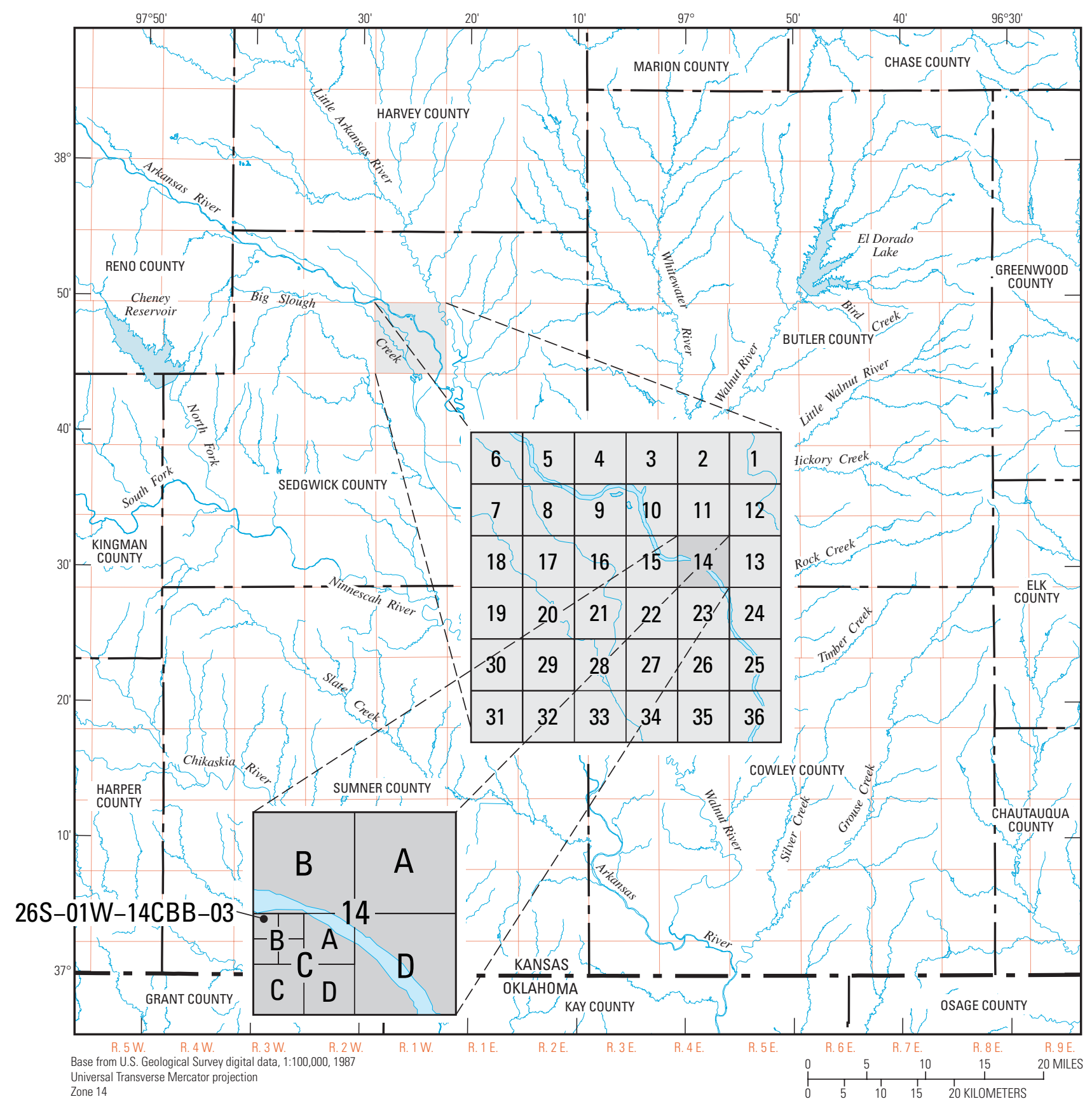

Horizontal coordinate information is referenced to the North American Datum of 1983 (NAD 83)

Figure 3. Local well-numbering system used in this report. 


\section{Characterization and Simulation of Flow in the Lower Arkansas River Alluvial Aquifer, South-Central Kansas}

Identification numbers for gaging stations in the Missouri River Basin begin with "06," and identification numbers for gaging stations in the lower Mississippi River Basin begin with "07." The other six digits are downstream-order numbers.

The identification numbers for miscellaneous wells and surface-water sites are a 15-digit number. The first six digits generally denote the latitude in degrees, minutes, and seconds. The next seven digits generally denote the longitude in degrees, minutes, and seconds, and the last two digits (assigned sequentially) identify the well or surface-water site within a 1-second grid. The miscellaneous site identification number, once assigned, is a pure number and is not changed if for example the original latitude and longitude are found to be in error.

\section{Previous Hydrologic Studies}

The importance of and concern about water resources in the four-county study area are evident from the numerous reports that have been published during the past 90 years covering a variety of hydrologic topics. Early studies were based on few data and provided only brief descriptions of ground- and surface-water quality (Parker, 1911) and well yields and quality of water available for irrigation supplies (Meinzer, 1914).

The Equus Beds aquifer north and west of Wichita has received the most attention as it is a major source of water supply for Wichita, the area's largest and fastest growing metropolitan area. Emergency water supplies in the Wichita area were evaluated by Lane and others (1962). Lawrence and Hess (1963) described Wichita's past, present, and future water supplies. Petri and others (1964) described the ground- and surfacewater resources of the Wichita area with respect to industrial supplies. The continuing multi-year Equus Beds Ground-Water Recharge Demonstration Project, that began in 1995, is a cooperative effort among the city of Wichita, Bureau of Reclamation, and USGS. The project has resulted in numerous published reports that can be viewed on the World Wide Web at URL: http://ks.water.usgs.gov/Kansas/studies/equus/

Williams and Lohman (1949) authored a comprehensive report on the geology and ground-water resources of southcentral Kansas with a special reference to the Wichita water supply. Dugan and Peckenpaugh (1985) described the effects of climate, vegetation, and soils on consumptive water use and ground-water recharge to the Central Midwest regional aquifer system that underlies the four-county study area. A geologic map of Butler County was published by the Kansas Geological Survey (Aber, 1993). Individual reports on the geology and water resources were written for Cowley County (Bayne, 1962), Sedgwick County (Lane and Miller, 1965a,b; Bevans, 1988,1989), and Sumner County (Walters, 1961).

Several studies have dealt with saline-water problems in the four-county study area (Leonard and Kleinschmidt, 1976; Gogel, 1981; Engineering Enterprises, Inc., 1982; Spinazola and others, 1985; Myers and others, 1996). Ground-water quality at potential or identified hazardous-waste sites in the area has been studied by Hart and Spruill (1988), Spruill (1988,
1990), and Myers and others (1993). Surface-water quality in the Walnut and South Fork Ninnescah River Basins were discussed by Diaz (1962, 1965).

The application of ground-water flow models in the study area (Sophocleous, 1983; Gogel, 1981; Spinazola and other, 1985; Myers and others 1996) underscore the need for accurate estimates of aquifer characteristics. Richards and Dunaway (1972) published geohydrologic data for numerical modeling of ground-water withdrawals in the Little Arkansas River Basin. Reed and Burnett (1985) compiled the results of aquifer performance tests, and Hansen (1991) provided estimates of freshwater storage and potential natural recharge.

\section{Acknowledgments}

The authors wish to thank the landowners of Butler, Cowley, Sedgwick, and Sumner Counties who allowed access to their lands and wells for water-level and streamflow measurements and water-quality sampling during this study.

\section{Characterization of Study Area}

\section{Physiographic Setting}

The four-county study area consisting of Butler, Cowley, Sedgwick, and Sumner Counties in south-central Kansas is located at the western edge of the Central Lowland physiographic province (Schoewe, 1949) (fig. 4). That part of the study area drained by the Arkansas River and its tributaries, including the Ninnescah River, is part of the Arkansas River Lowlands section of the Central Lowland.

The Arkansas River Lowlands section is divided into the Finney Lowland, the Great Bend Lowland, the McPherson Lowland, and the Wellington Lowland. The Great Bend Lowland includes that part of the study area that is drained by the Arkansas and Little Arkansas Rivers and is described as a flat, smooth plain, with local relief ranging from 0 to $300 \mathrm{ft}$ (Hammond, 1964). Agriculture; the production of oil; milling, storage, and shipment of grain; and manufacturing are the important industries in this part of the study area. Along with Wichita, cities in the Great Bend Lowland in the study area include Andale, Arkansas City, Haysville, Mount Hope, and Valley Center (fig. 1). The Wellington Lowland includes that part of the study area drained by the Ninnescah River and is described by Hammond (1964) as an irregular plain with local relief ranging from 100 to $300 \mathrm{ft}$. Agriculture and the production of oil and gas are the two outstanding industries in this part of the study area. Cities in the Wellington Lowland include Belle Plaine, Garden Plain, Goddard, and Wellington (fig. 1).

Nearly all of Butler County, a large part of Cowley County, and northeastern Sedgwick County, are part of the Flint Hills Upland, which is the western subdivision of the Osage Plains physiographic province. The surface of the Flint Hills 


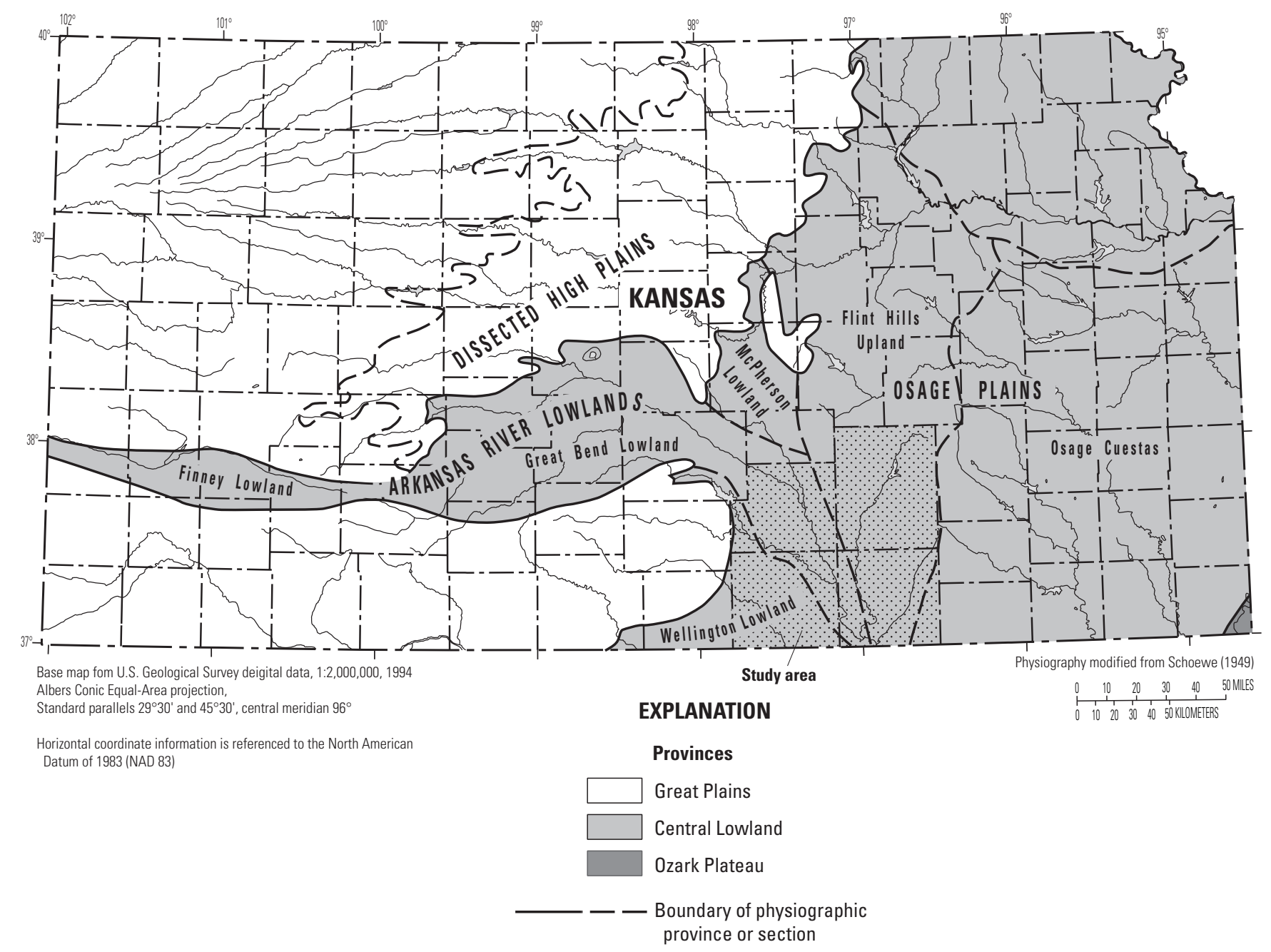

Figure 4. Physiographic provinces in Kansas (modified from Schoewe, 1949).

Upland is gently rolling (local relief of about $350 \mathrm{ft}$ ) and merges on the west with a smooth and gentle slope that trends toward the Arkansas River Valley. The Flint Hills are strewn with a large amount of flint and chert from which they derive their name. South of the Kansas River, the Flint Hill Upland comprises about $16,000 \mathrm{mi}^{2}$ of one of the finest grazing areas in the State if not elsewhere in the United States because of the bluestem grass that flourishes there. The Flint Hills Upland is also the location of some of the more important oil and gas fields in eastern Kansas (Schoewe, 1949). Cities in the Flint Hills Upland section of the study area include Augusta, El Dorado, and Winfield (fig. 1).

\section{Soils}

Soils in the four-county study area belong to the soil order Mollisol (U.S. Soil Conservation Service, 1967). Mollisols are some of the most productive agricultural soils in the world and are characterized by a surface horizon that is thick, dark, and rich in organic materials. Mollisoils have a granular or crumb structure and are not hard when dry (Brady, 1974). Soils in the
Arkansas River Valley belong to the suborder Udoll, which is usually moist and has no horizons in which either gypsum or calcium carbonate has accumulated. Upland soils belong to the suborder Ustoll, which is intermittently dry during the warm part of the year or has subsurface horizons in which salt or carbonate has accumulated.

Individual soil surveys for Butler (Penner and others, 1975), Cowley (Horsch, 1980), Sedgwick (Penner and Wehmueller, 1979), and Sumner (Fenwick and Ratcliff, 1979) Counties were published by the U.S. Department of Agriculture. These county surveys contain detailed soil maps, information about the use and management of soil, and information on engineering properties, physical and chemical properties, and soil and water features.

With all other factors being equal, watersheds with soils of low permeability exhibit less infiltration to ground water than watersheds with highly permeable soils, which tend to allow greater infiltration and a greater ground-water contribution to base flow of streams. Soil permeability in Butler County ranges from less than 0.06 to $2.0 \mathrm{in} / \mathrm{hr}$ (Penner and others, 1975) and in Cowley County from less than 0.06 to $6.0 \mathrm{in} / \mathrm{hr}$ (Horsch, 1980). 


\section{Characterization and Simulation of Flow in the Lower Arkansas River Alluvial Aquifer, South-Central Kansas}

Soil permeability in Sedgwick and Sumner Counties ranges from less than 0.06 to $20.0 \mathrm{in} / \mathrm{hr}$ (Penner and Wehmueller, 1979; Fenwick and Ratcliff, 1979) with soil permeability generally greatest in the alluvial valleys. A map of equal mean soil permeability from county soil maps for the study area is shown in figure 5 (U.S. Department of Agriculture, 1996).

\section{Precipitation and Surface Water}

Climate in the four-county area is affected by the movement of various air masses of tropical and continental origin over the open, inland plains, and seasonal precipitation extremes are common. About 70 percent of the mean annual precipitation falls from April through September. Precipitation during early spring and late fall occurs in association with frontal air masses that produce low-intensity rainfall of regional coverage. During the summer months, the weather is dominated by warm, moist air from the Gulf of Mexico or by hot, dry air from the Southwest. Summer precipitation generally occurs as high-intensity thunderstorms.

The study area is characterized by large variations in seasonal temperatures, moderate precipitation, and windy conditions. Average maximum monthly temperatures in the fourcounty study area range from $40.6{ }^{\circ} \mathrm{F}$ in January at Wichita to $93.5^{\circ} \mathrm{F}$ in July at Wellington. Average minimum temperatures range from $20.2{ }^{\circ} \mathrm{F}$ in January to $69.9^{\circ} \mathrm{F}$ in July at Wichita (High Plains Regional Climate Center, 2003) (fig. 6).

Average total monthly precipitation in the study area ranges from 0.73 in. in January at Wichita to 4.91 in. in May at Arkansas City (High Plains Regional Climate Center, 2003). Normal annual precipitation for 1961-90 ranged from 30.14 in. in Sedgwick County to 34.42 in. in Butler County (Kansas State University, 2003). Total annual and normal (1961-90) precipitation for Arkansas City, El Dorado, Wellington, Wichita, and Winfield are shown in figure 7.

Major streams draining the four-county study area are the Arkansas, Chikaskia, Ninnescah, and Walnut Rivers and Cowskin Creek. There are currently (2004) 13 USGS continuous-record streamflow-gaging stations operating in the fourcounty study area (fig. 8, table 1) that measure water levels (gage height) to determine streamflow discharge of area streams. In addition, one gaging station (07144790, Cheney Reservoir near Cheney) measures the water elevation to determine the contents of Cheney Reservoir, a major water-supply source for the city of Wichita. Data from these 14 gaging stations are available in near real time on the World Wide Web at URL http://ks.water.usgs.gov/

\section{Geology}

\section{Consolidated Rocks}

The oldest surficial rocks in the study area are Late Pennsylvanian in age and crop out in southeastern Cowley County
(Wabaunsee Group; Bayne, 1962) (fig. 9 and table 2). Consolidated rocks of Early Permian age (Admire, Council Grove, and Chase Groups) underlie much of the upland areas in the eastern two-thirds of Butler (Aber, 1993) and Cowley (Bayne, 1962) Counties. The Wellington Formation and Ninnescah Shale (Sumner Group) of Early Permian age occupy upland areas in Sedgwick (Lane and Miller, 1965a) and Sumner (Walters, 1961) Counties and the western one-third of Butler and Cowley Counties (fig. 9).

The Wellington Formation of Early Permian age forms the bedrock surface in much of Sedgwick County and the eastern two-thirds of Sumner County. The Ninnescah Shale, also of Early Permian age, constitutes the bedrock surface in the western one-third of Sumner County, rocks of the Early Permian form the bedrock surface in much of the eastern two-thirds of Butler and Cowley Counties, and rocks of Late Pennsylvanian age create the bedrock surface in extreme southeastern Cowley County.

\section{Unconsolidated Deposits}

The surficial unconsolidated deposits in the study area are not marine in origin but fluvial sediment deposited by flowing streams across the continental interior (Frye and Leonard, 1952). Unconsolidated deposits in Kansas are assigned mostly to the Quaternary System (Pleistocene and Holocene Series). Pleistocene deposits are composed of silt, clay, sand, and gravel. The Pleistocene Series in Kansas has been divided into the pre-Illinoisan and Wisconsinan glacial stages, and the Aftonian, Yarmouthian, and Sangamonian interglacial stages. It was during Illinoisan time that most of the present-day large streams in the State, including the Arkansas River, were established. Throughout Pleistocene time the major streams draining the upland areas of the study area were cutting their channels near their present courses. Sediments deposited by these streams were composed of locally derived material, chiefly pebbles of limestone and chert, whereas sediments deposited by the Arkansas River contained large grains of quartz or feldspar derived mainly from the Pliocene Ogallala Formation in the western part of the State (Bayne, 1962).

Alluvium occupies the valleys of all the major streams in the four-county study area, but all streams except the Arkansas River are deepening their channels over much of their courses and, consequently, alluvium is present only in the narrow active channels of these streams. In the Arkansas River Valley, however, the alluvium deposited after the pre-Illinoisan glacial period that lies adjacent to the stream is as much as 16-mi wide in northern Sedgwick County (fig. 9) and nearly 1-mi wide in Cowley County and as much as $50 \mathrm{ft}$ thick (Bayne, 1962).

Unconsolidated deposits occur over the consolidated bedrock in much of Sedgwick County, with undifferentiated Pliocene and lower Pleistocene deposits as much as $160 \mathrm{ft}$ thick occupying much of the basal part of the Arkansas River Valley north of Wichita, and lower Pleistocene deposits occupying the basal part of the Arkansas River Valley south of Wichita at 


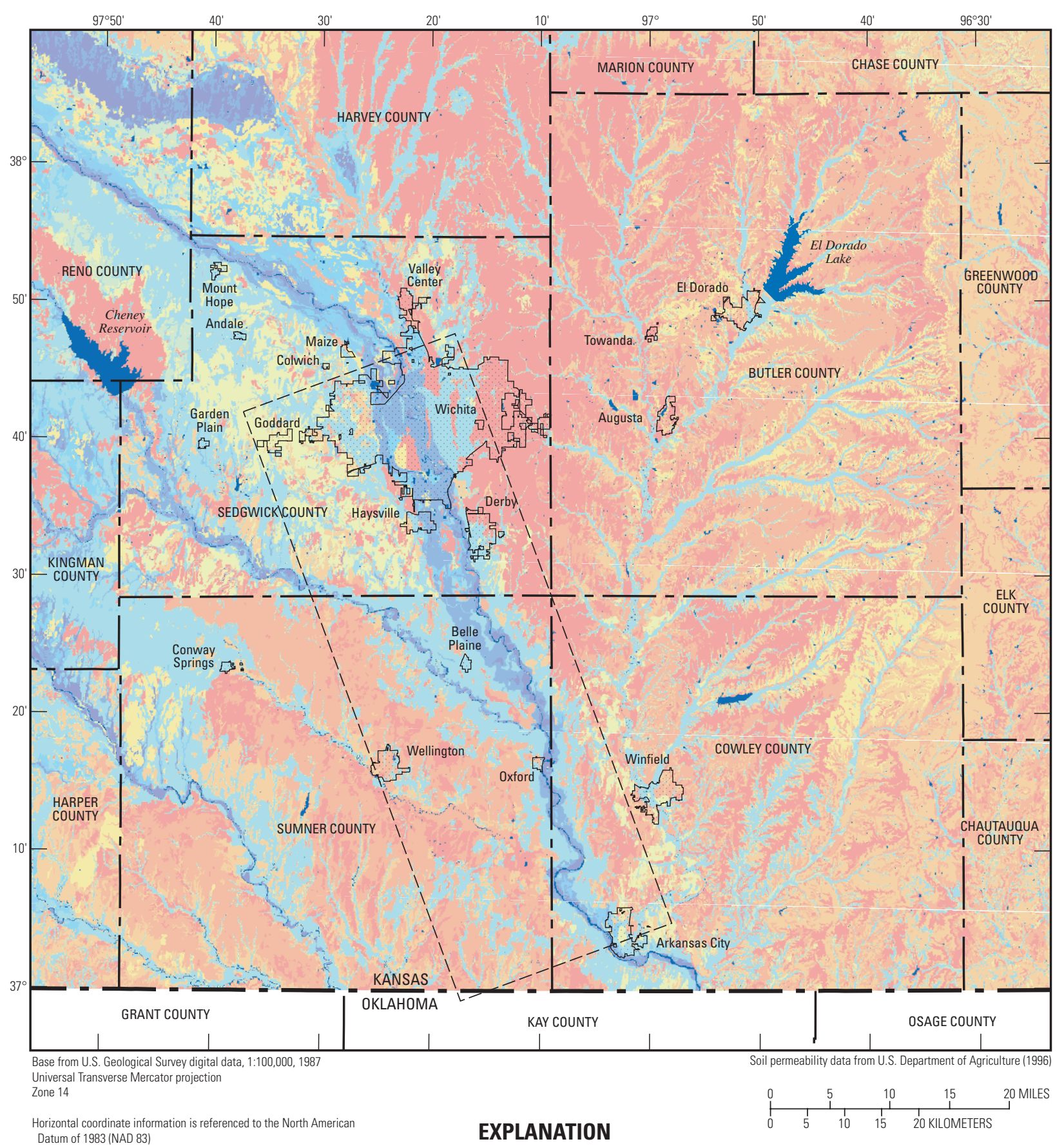

Areas of equal mean soil permeability, in inches per hour

\begin{tabular}{|c|c|c|c|}
\hline $0.01-0.18$ & $0.64-0.87$ & $1.28-1.29$ & $6.23-12.99$ \\
\hline $0.18-0.34$ & $0.87-1.09$ & $1.29-2.75$ & $12.99-17.60$ \\
\hline $0.34-0.64$ & $1.09-1.28$ & $2.75-6.23$ & Water \\
\hline
\end{tabular}

---- Boundary of modeled area

Figure 5. Areas of equal mean soil permeability in study area (data from U.S. Department of Agriculture, 1996). 

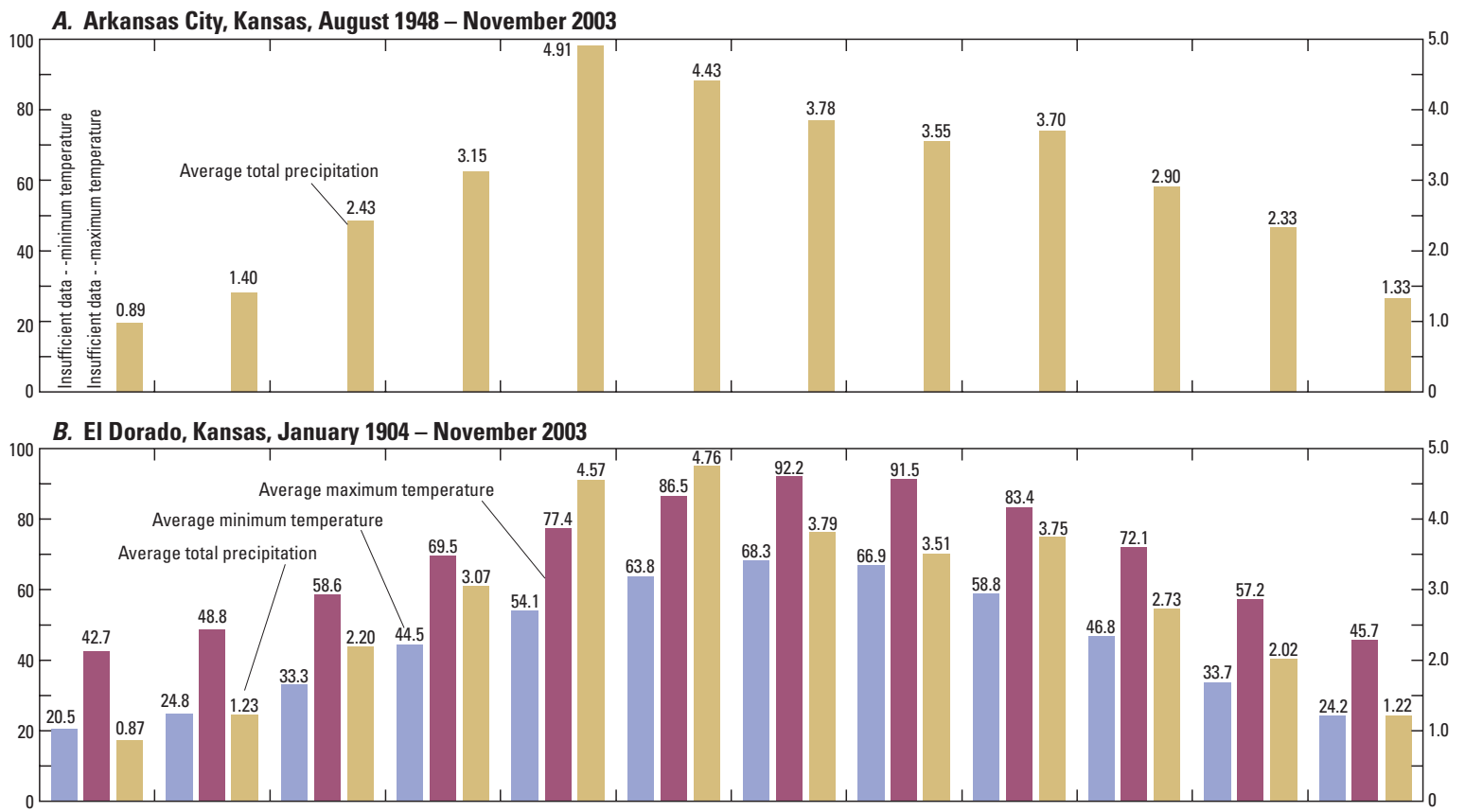

C. Wellington, Kansas, August 1948 - November 2003
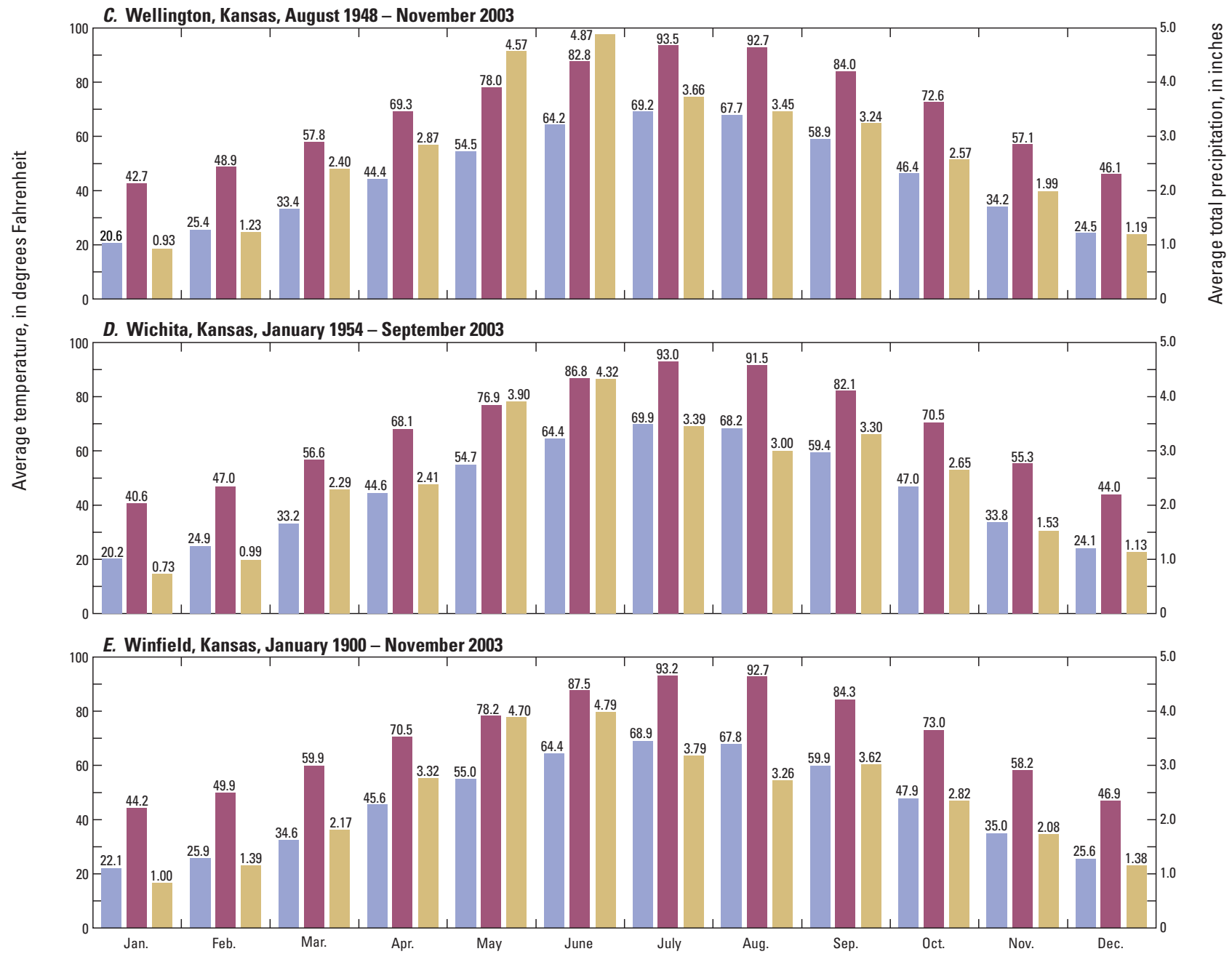

Figure 6. Average minimum and maximum monthly temperatures and average monthly precipitation at (A) Arkansas City, (B) El Dorado, (C) Wellington, (D)Wichita, and (E) Winfield. Data from High Plains Regional Climate Center (2003). 
A. Arkansas City, Kansas, August 1948 - December 2003

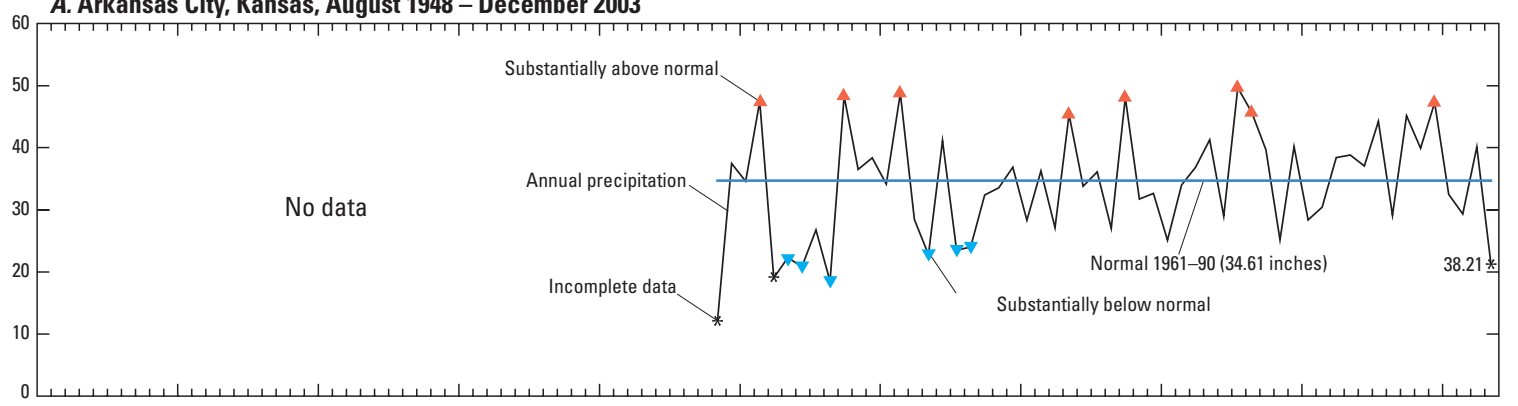

B. El Dorado, Kansas, January 1904 - December 2003

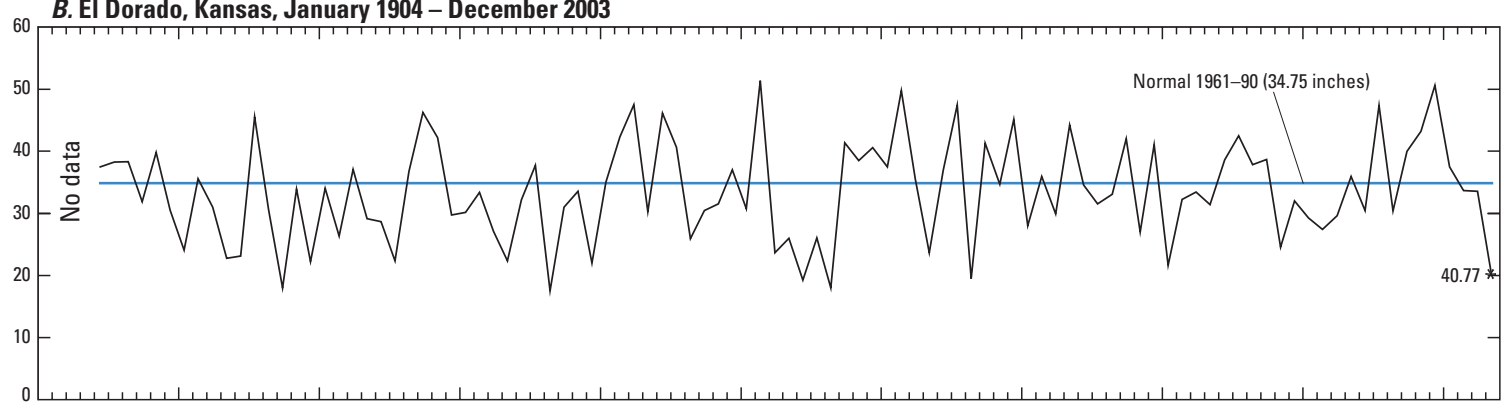

C. Wellington, Kansas, August 1948 - December 2003

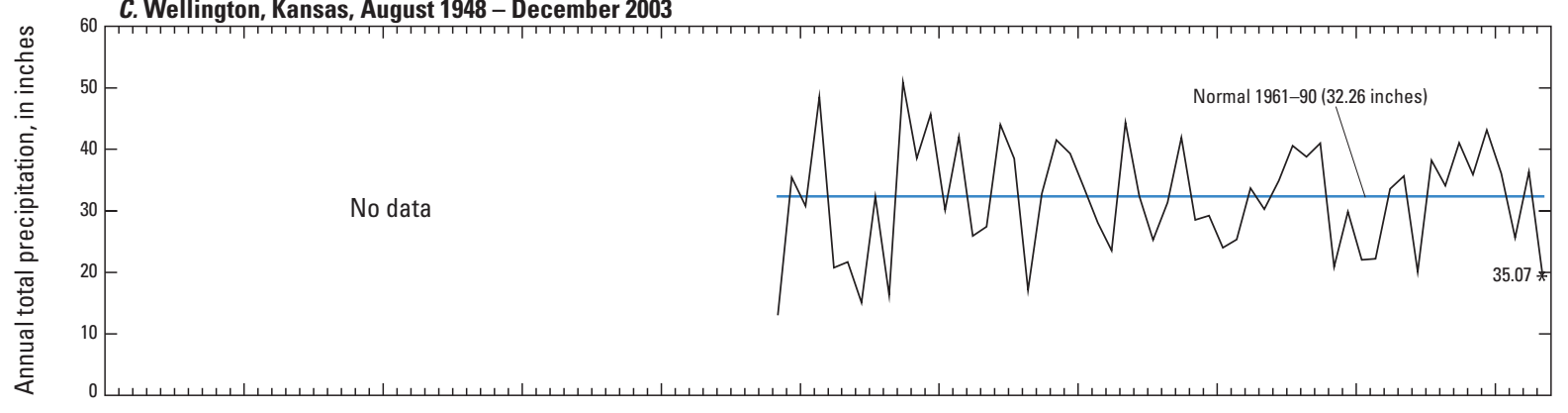

D. Wichita, Kansas, January 1954 - December 2003
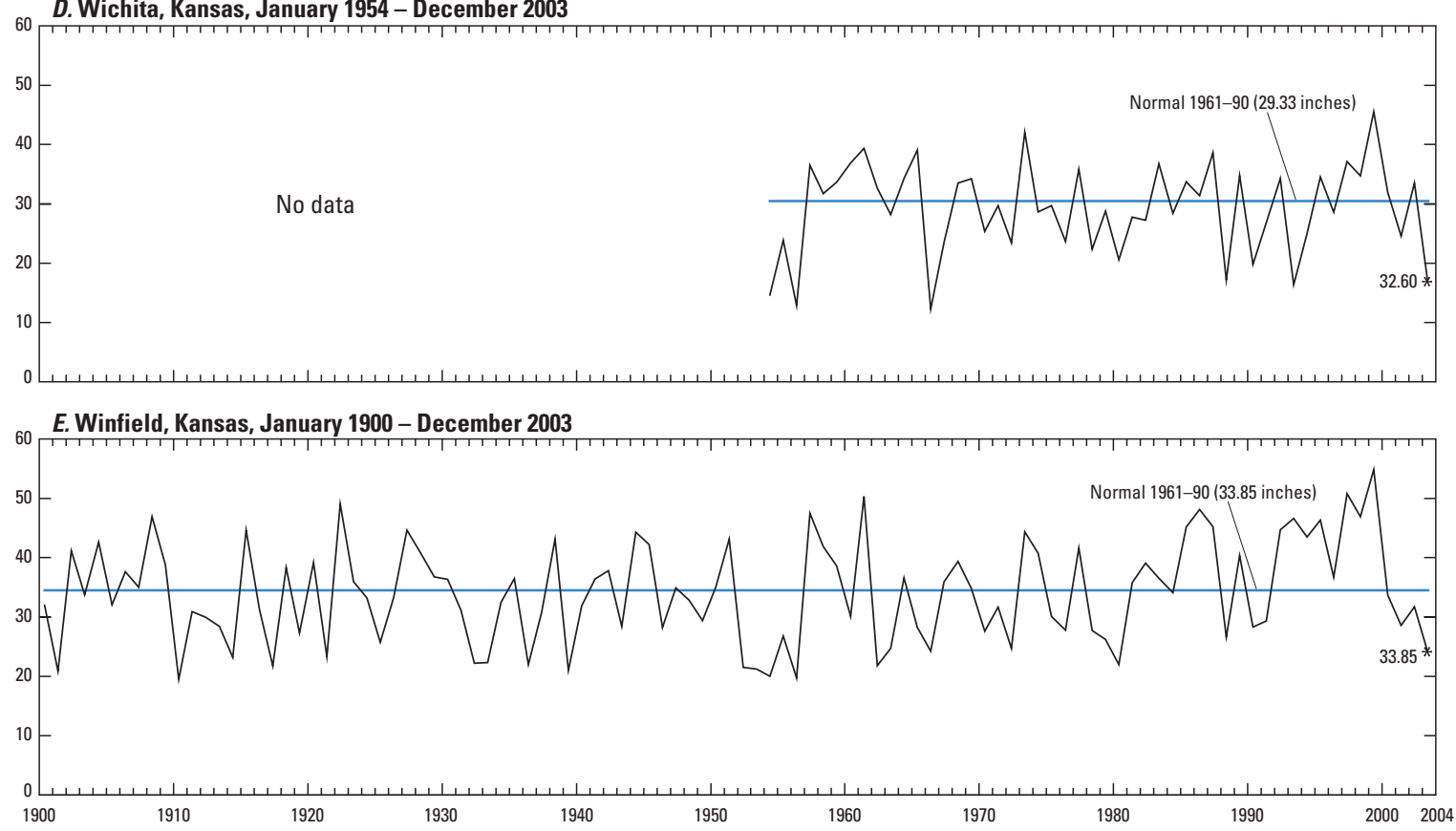

Figure 7. Total annual and normal (1961-90) precipitation at (A) Arkansas City, $(B)$ El Dorado, (C) Wellington, (D)Wichita, and (E) Winfield. Data from High Plains Regional Climate Center (2003) and Kansas State University (2003). 


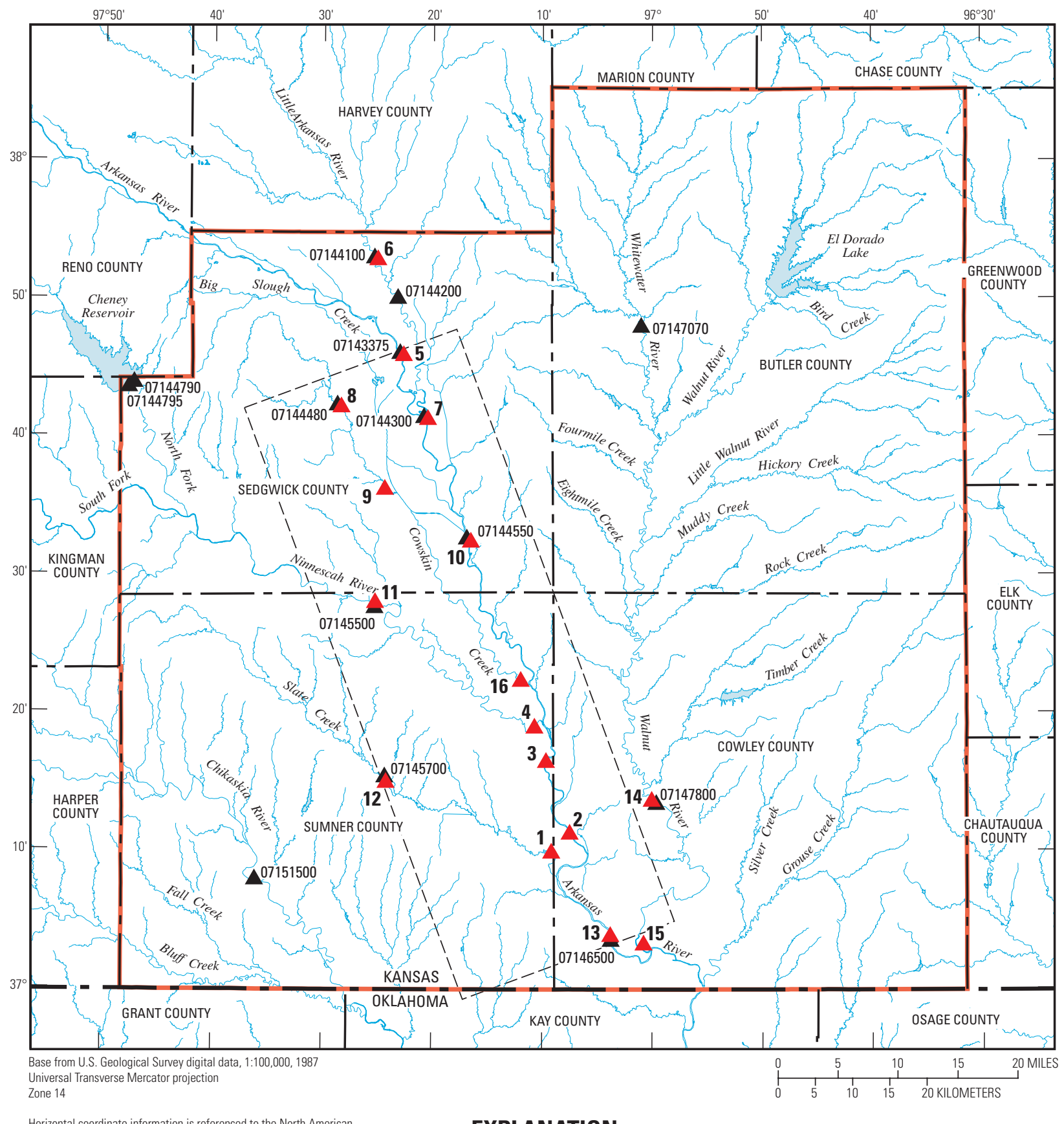

Horizontal coordinate information is referenced to the North American Datum of 1983 (NAD 83)

\section{EXPLANATION}

\section{Boundary of modeled area}

Boundary of four-county study area
07146500 Current U.S. Geological Survey streamflow-gaging station and site identification number

13 Miscellaneous streamflow measurement site-Number is map number given in table 13

Figure 8. Location of currently (2004) active U.S. Geological Survey gaging stations in study area and sites where miscellaneous streamflow measurements were made, 2001-03. 
Table 1. Drainage area, period of record, and annual median and maximum peak discharge for period of record at 14 currently (2004) active U.S. Geological Survey gaging stations in Butler, Cowley, Sedgwick, and Sumner Counties, south-central Kansas.

[Data from Putnam and Schneider, 2004. NA, not applicable]

\begin{tabular}{|c|c|c|c|c|c|}
\hline \multirow{2}{*}{$\begin{array}{l}\text { U.S. Geological } \\
\text { Survey } \\
\text { identification } \\
\text { number } \\
\text { (fig. 8) }\end{array}$} & \multirow[b]{2}{*}{ Station name } & \multirow{2}{*}{$\begin{array}{l}\text { Drainage area } \\
\text { (square miles) }\end{array}$} & \multirow{2}{*}{$\begin{array}{c}\text { Period of } \\
\text { record } \\
\text { (water years) }\end{array}$} & \multicolumn{2}{|c|}{$\begin{array}{c}\text { Discharge } \\
\text { (cubic feet per second) }\end{array}$} \\
\hline & & & & $\begin{array}{l}\text { Annual median } \\
\text { for period of } \\
\text { record }\end{array}$ & $\begin{array}{l}\text { Maximum peak } \\
\text { for period of } \\
\text { record }\end{array}$ \\
\hline 07143375 & Arkansas River near Maize, Kansas & 39,110 & $1988-2003$ & 276 & 45,900 \\
\hline 07144100 & Little Arkansas River near Sedgwick, Kansas & 1,239 & 1994-2003 & 61 & 17,600 \\
\hline 07144200 & Little Arkansas River at Valley Center, Kansas & 1,327 & $1923-2003$ & 59 & 32,000 \\
\hline 07144300 & Arkansas River at Wichita, Kansas & 40,490 & $1935-2003$ & 435 & 48,400 \\
\hline 07144480 & Cowskin Creek at 119th Street at Wichita, Kansas & 86.0 & $2001-03$ & 3.8 & 1,420 \\
\hline 07144550 & Arkansas River at Derby, Kansas & 40,830 & $1969-2003$ & 526 & 58,300 \\
\hline 07144790 & Cheney Reservoir near Cheney, Kansas ${ }^{1}$ & ${ }^{2} 901$ & $1965-2003$ & NA & NA \\
\hline 07144795 & North Fork Ninnescah River at Cheney Dam, Kansas & ${ }^{2} 901$ & $1965-2003$ & .48 & 2,070 \\
\hline 07145500 & Ninnescah River near Peck, Kansas & 2,129 & $1938-2003$ & 240 & 38,200 \\
\hline 07145700 & Slate Creek at Wellington, Kansas & 154 & $1970-2003$ & 8.2 & 28,500 \\
\hline 07146500 & Arkansas River at Arkansas City, Kansas & ${ }^{3} 43,713$ & $1903-2003$ & 907 & 103,000 \\
\hline 07147070 & Whitewater River at Towanda, Kansas & 426 & $1962-2003$ & 35 & 80,600 \\
\hline 07147800 & Walnut River at Winfield, Kansas & 1,880 & $1922-2003$ & 168 & 105,000 \\
\hline 07151500 & Chikaskia River near Corbin, Kansas & 794 & $1951-2003$ & 97 & 39,300 \\
\hline
\end{tabular}

${ }^{1}$ Conservation pool elevation is between 1,329.2 and 1,421.6 feet above NAVD 88 with a content of 151,800 acre-feet. Maximum elevation was $1,429.4$ feet on June 11,1995 , with a content of 252,980 acre-feet.

${ }^{2}$ Drainage area is 901 square miles of which 237 square miles are probably noncontributing.

${ }^{3}$ Drainage area is 43,713 square miles of which 7,607 square miles are probably noncontributing.

thicknesses of as much as $70 \mathrm{ft}$. Loess deposits of Illinoisan to Holocene age occur over bedrock and lower Pleistocene deposits in most of the upland areas at thicknesses of as much as $74 \mathrm{ft}$. Alluvium and terrace deposits of Wisconsinan to Holocene age overlie the basal part of Arkansas River Valley (as much as $60 \mathrm{ft}$ thick) and the Ninnescah River Valley in Sedgwick County (as much as $50 \mathrm{ft}$ thick) (Bevans, 1989).

Unconsolidated deposits of Quaternary age consisting of alluvium, loess, and terrace deposits (Pleistocene and Holocene age) occur only along major streams in Butler County, principally the Little Walnut, Walnut, and Whitewater Rivers and Eightmile, Fourmile, Hickory, Muddy, and Rock Creeks (Aber, 1993).

In northwestern Sumner County, unconsolidated terrace deposits (pre-Illinoisan glacial stage of the Lower Pleistocene) underlie the surface near Conway Springs (northwestern part of county). Illinoisan and Wisconsinan terrace deposits border most of the major streams, and Holocene deposits form the flood plains (alluvium) and also occur as dune sand (Walters, 1961).

In Cowley County, Pleistocene deposits of the preIllinoisan and Illinoisan glacial stages occur only along the
Arkansas and Walnut Rivers; later Wisconsinan terrace deposits also are found along the major rivers and Grouse and Silver Creeks. Alluvium deposited after the pre-Illinoisan glacial stage occupies the valleys of all the major streams in Cowley County (Bayne, 1962).

\section{Land Use}

Activities associated with land use often affect the quantity and quality of water resources. Land use in the four-county study area is primarily agricultural (fig. 10, table 3). In 1990, the mean percentage of agricultural land use in the four-county area was about 95 percent. Grassland was dominant in Butler and Cowley Counties, whereas cropland dominated agricultural land use in Sedgwick and Sumner Counties. Urban land use made up only about 3.3 percent of the total land use for the study area in 1990, with Sedgwick County having the largest total urban land-use percentage (about 12 percent) (table 3). Population growth and the resulting land-use change are occurring southeast of Wichita. 


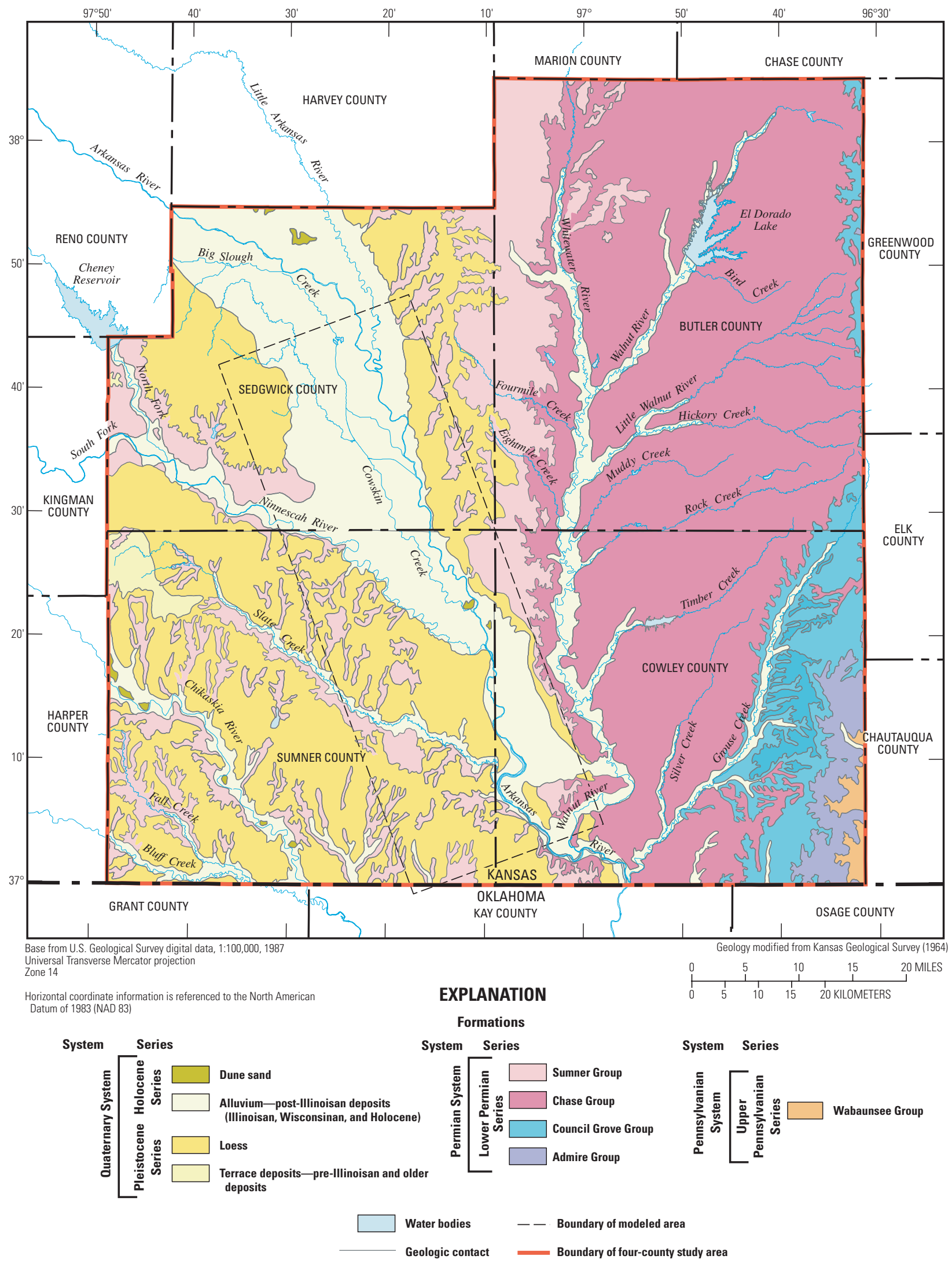

Figure 9. Generalized surficial geology in study area. 
Table 2. Generalized geohydrologic section for Butler, Cowley, Sedgwick, and Sumner Counties, south-central Kansas.

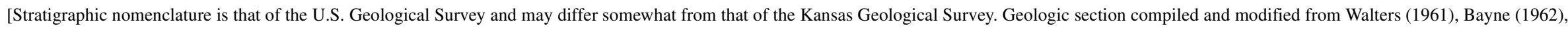
Lane and Miller (1965a), and Aber (1993). Shading indicates those units included in the alluvial aquifer as described in this report. gal/min, gallons per minute; \pm , plus or minus]

\begin{tabular}{|c|c|c|c|c|c|c|c|c|}
\hline System & Series & Subseries & $\begin{array}{l}\text { Stage or } \\
\text { group }\end{array}$ & Stratigraphic unit & $\begin{array}{l}\text { Thickness } \\
\text { (feet) }\end{array}$ & Physical characteristics & Water-supply characteristics & County \\
\hline \multirow{8}{*}{ Quaternary } & \multirow[b]{2}{*}{ Holocene } & & & Dune sand & $0-30$ & Sand, medium and fine, some silt. & $\begin{array}{l}\text { Generally above the water table. Does } \\
\text { not yield water to wells. }\end{array}$ & $\begin{array}{l}\text { Sedgwick, } \\
\text { Sumner }\end{array}$ \\
\hline & & & & Alluvium & $0-75$ & $\begin{array}{l}\text { Silt, clay, and arkosic sand and gravel } \\
\text { in Arkansas River Valley. Silt, } \\
\text { clay, sand, and gravel in other } \\
\text { stream valleys. }\end{array}$ & $\begin{array}{l}\text { Yields large quantities of water to } \\
\text { wells in Arkansas River Valley; } \\
\text { small to moderate quantities in } \\
\text { other stream valleys. }\end{array}$ & $\begin{array}{l}\text { Butler, } \\
\text { Cowley, } \\
\text { Sedgwick, } \\
\text { Sumner }\end{array}$ \\
\hline & \multirow{6}{*}{ Pleistocene } & \multirow{4}{*}{$\begin{array}{c}\text { Upper } \\
\text { Pleistocene }\end{array}$} & \multirow[b]{3}{*}{$\begin{array}{l}\text { Wiscon- } \\
\text { sinan } \\
\text { Stage }\end{array}$} & Colluvium & $0-30$ & $\begin{array}{l}\text { Silt and clay, minor amounts of sand } \\
\text { and gravel, resembling the } \\
\text { underlying bedrock material. }\end{array}$ & $\begin{array}{l}\text { Generally above water table; locally, } \\
\text { does not yield appreciable quanti- } \\
\text { ties of water to wells. }\end{array}$ & $\begin{array}{l}\text { Sedgwick, } \\
\text { Sumner }\end{array}$ \\
\hline & & & & Loess & $0-74$ & $\begin{array}{l}\text { Wind-deposited silt, generally in } \\
\text { upland position. Locally may } \\
\text { contain silt older than } \\
\text { Wisconsinan age. }\end{array}$ & $\begin{array}{l}\text { Lies above water table and yields no } \\
\text { water to wells. }\end{array}$ & $\begin{array}{l}\text { Butler, } \\
\text { Cowley, } \\
\text { Sedgwick }\end{array}$ \\
\hline & & & & Terrace deposits & $0-75$ & $\begin{array}{l}\text { Silt, clay, and arkosic sand and gravel } \\
\text { in Arkansas River Valley. Locally } \\
\text { in Walnut River Valley, these } \\
\text { deposits contain chert gravel. Can } \\
\text { be differentiated from alluvium } \\
\text { only by topographic position. }\end{array}$ & $\begin{array}{l}\text { Large quantities of water of good to } \\
\text { poor quality available in Arkansas } \\
\text { River Valley. Small to moderate } \\
\text { supplies of hard water available in } \\
\text { other major stream valleys. }\end{array}$ & $\begin{array}{l}\text { Butler, } \\
\text { Cowley, } \\
\text { Sedgwick, } \\
\text { Sumner }\end{array}$ \\
\hline & & & $\begin{array}{l}\text { Illinoisan } \\
\text { Stage }\end{array}$ & $\begin{array}{l}\text { Crete and } \\
\text { Loveland } \\
\text { Formations }\end{array}$ & $0-65$ & $\begin{array}{l}\text { Poorly sorted sand and gravel; contain } \\
\text { considerable red-brown silt and } \\
\text { locally derived limestone and shale } \\
\text { fragments. }\end{array}$ & $\begin{array}{l}\text { In Walnut River Valley, these deposits } \\
\text { are above the water table and yield } \\
\text { no water. In Arkansas River Val- } \\
\text { ley, yield small to moderate quanti- } \\
\text { ties of water to wells. }\end{array}$ & $\begin{array}{l}\text { Cowley, } \\
\text { Sumner }\end{array}$ \\
\hline & & \multirow{2}{*}{$\begin{array}{l}\text { Lower } \\
\text { Pleistocene }\end{array}$} & \multirow{2}{*}{$\begin{array}{l}\text { Pre- } \\
\text { Illinoisan } \\
\text { Stage }\end{array}$} & $\begin{array}{l}\text { Sappa and Grand } \\
\text { Island Formations }\end{array}$ & 0-90 & $\begin{array}{l}\text { Poorly sorted sand and gravel; locally } \\
\text { contains much silt and clay. }\end{array}$ & $\begin{array}{l}\text { Yield small to moderate }(50 \mathrm{gal} / \mathrm{min}) \\
\text { quantities of water to wells. }\end{array}$ & $\begin{array}{l}\text { Cowley, } \\
\text { Sedgwick, } \\
\text { Sumner }\end{array}$ \\
\hline & & & & Terrace deposits & $0-90$ & $\begin{array}{l}\text { Chiefly, medium to coarse sand; } \\
\text { contain some silt and clay. }\end{array}$ & $\begin{array}{l}\text { Yield moderate quantities of water to } \\
\text { wells. }\end{array}$ & $\begin{array}{l}\text { Butler, } \\
\text { Sedgwick, } \\
\text { Sumner }\end{array}$ \\
\hline Tertiary & Pliocene & & & $\begin{array}{l}\text { Undifferentiated } \\
\text { deposits }\end{array}$ & $150 \pm$ & $\begin{array}{l}\text { Composed of lenticular beds of } \\
\text { calcareous silt and clay, fine to } \\
\text { coarse sand, and fine to coarse } \\
\text { gravel. In subsurface only, these } \\
\text { unconsolidated deposits and the } \\
\text { overlying Pleistocene units are } \\
\text { known locally as the Equus Beds } \\
\text { aquifer north of Wichita. }\end{array}$ & $\begin{array}{l}\text { Contributes large supplies of good } \\
\text { quality water to many municipal, } \\
\text { irrigation, and industrial wells } \\
\text { screened in multiple porous zones } \\
\text { that penetrate the complete section } \\
\text { of unconsolidated deposits. }\end{array}$ & Sedgwick \\
\hline
\end{tabular}


Table 2. Generalized geohydrologic section for Butler, Cowley, Sedgwick, and Sumner Counties, south-central Kansas.-Continued

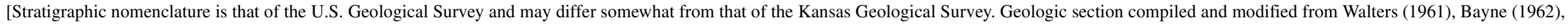
Lane and Miller (1965a), and Aber (1993). Shading indicates those units included in the alluvial aquifer as described in this report. gal/min, gallons per minute; \pm , plus or minus]

\begin{tabular}{|c|c|c|c|c|c|c|c|c|}
\hline System & Series & Subseries & $\begin{array}{l}\text { Stage or } \\
\text { group }\end{array}$ & Stratigraphic unit & $\begin{array}{l}\text { Thickness } \\
\text { (feet) }\end{array}$ & Physical characteristics & Water-supply characteristics & County \\
\hline \multirow{8}{*}{ Permian } & \multirow{8}{*}{$\begin{array}{l}\text { Lower } \\
\text { Permian }\end{array}$} & & \multirow{2}{*}{$\begin{array}{l}\text { Sumner } \\
\text { Group }\end{array}$} & Ninnescah Shale & $0-250$ & $\begin{array}{l}\text { Predominantly silty shale; contains } \\
\text { beds of dolomite, calcareous } \\
\text { siltstone, and fine-grained } \\
\text { sandstone. }\end{array}$ & $\begin{array}{l}\text { Yields small quantities of hard water } \\
\text { to wells. }\end{array}$ & $\begin{array}{l}\text { Sedgwick, } \\
\text { Sumner }\end{array}$ \\
\hline & & & & $\begin{array}{l}\text { Wellington } \\
\text { Formation }\end{array}$ & $0-650$ & $\begin{array}{l}\text { Chiefly shale and silty shale; contains } \\
\text { lenticular beds of gypsum, silty } \\
\text { limestone, dolomite, and the thick } \\
\text { Hutchinson Salt Member. }\end{array}$ & $\begin{array}{l}\text { Yields small to moderate quantities of } \\
\text { hard water to wells east of the } \\
\text { Arkansas River Valley. }\end{array}$ & $\begin{array}{l}\text { Butler, } \\
\text { Cowley } \\
\text { Sedgwick, } \\
\text { Sumner }\end{array}$ \\
\hline & & & \multirow{6}{*}{$\begin{array}{l}\text { Chase } \\
\text { Group }\end{array}$} & Nolans Limestone & $20-55$ & $\begin{array}{l}\text { Limestone and dolomite in upper part. } \\
\text { Calcareous shale in middle part; } \\
\text { contains some impure limestone. } \\
\text { Lower part, thinner and more dense } \\
\text { limestone separated by calcareous } \\
\text { shale. }\end{array}$ & $\begin{array}{l}\text { Locally yields small to large quantities } \\
\text { of water of good to poor quality } \\
\text { from the upper part, which contains } \\
\text { solution channels. Little, if any } \\
\text { water is obtained from the middle } \\
\text { and lower parts. }\end{array}$ & $\begin{array}{l}\text { Butler, } \\
\text { Cowley }\end{array}$ \\
\hline & & & & Odell Shale & $30-40$ & $\begin{array}{l}\text { Chiefly calcareous shale. Locally } \\
\text { dolomitic zones occur in upper and } \\
\text { middle parts. }\end{array}$ & Yields little water to wells in the area. & $\begin{array}{l}\text { Butler, } \\
\text { Cowley }\end{array}$ \\
\hline & & & & $\begin{array}{l}\text { Winfield } \\
\text { Limestone }\end{array}$ & $30_{ \pm}$ & $\begin{array}{l}\text { Limestone; locally may contain some } \\
\text { chert. }\end{array}$ & $\begin{array}{l}\text { Locally yields small to moderate quan- } \\
\text { tities of water to wells from weath- } \\
\text { ered upper part. }\end{array}$ & $\begin{array}{l}\text { Butler, } \\
\text { Cowley }\end{array}$ \\
\hline & & & & Doyle Shale & $65-100$ & Shale, separated by limestone. & $\begin{array}{l}\text { Locally, in subsurface, large to moder- } \\
\text { ate supplies of water of good to } \\
\text { poor quality are available from } \\
\text { solution channels in uppermost few } \\
\text { feet. Some water is available from } \\
\text { limestone beds near base. Quality } \\
\text { of water ranges from good to poor. }\end{array}$ & $\begin{array}{l}\text { Butler, } \\
\text { Cowley }\end{array}$ \\
\hline & & & & $\begin{array}{l}\text { Barneston } \\
\text { Limestone }\end{array}$ & $55-90$ & $\begin{array}{l}\text { Limestone in upper part; lower part } \\
\text { interbedded with chert. Chert } \\
\text { occurs in bands separated by } \\
\text { limestone. }\end{array}$ & $\begin{array}{l}\text { Upper weathered zone yields small to } \\
\text { moderate supplies of hard water to } \\
\text { wells. Middle and lower zones } \\
\text { yield small to large quantities of } \\
\text { water to wells and springs from } \\
\text { solution channels in local areas. }\end{array}$ & $\begin{array}{l}\text { Butler, } \\
\text { Cowley }\end{array}$ \\
\hline & & & & Matfield Shale & $30-65$ & $\begin{array}{l}\text { Shale, limy in part, separated by } \\
\text { limestone. }\end{array}$ & $\begin{array}{l}\text { Locally, yields small supplies of water } \\
\text { to wells from limestone part. }\end{array}$ & $\begin{array}{l}\text { Butler, } \\
\text { Cowley }\end{array}$ \\
\hline
\end{tabular}


Table 2. Generalized geohydrologic section for Butler, Cowley, Sedgwick, and Sumner Counties, south-central Kansas.—Continued

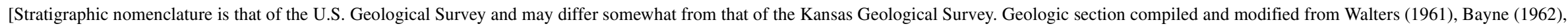
Lane and Miller (1965a), and Aber (1993). Shading indicates those units included in the alluvial aquifer as described in this report. gal/min, gallons per minute; \pm , plus or minus]

\begin{tabular}{|c|c|c|c|c|c|c|c|c|}
\hline System & Series & Subseries & $\begin{array}{l}\text { Stage or } \\
\text { group }\end{array}$ & Stratigraphic unit & $\begin{array}{l}\text { Thickness } \\
\text { (feet) }\end{array}$ & Physical characteristics & Water-supply characteristics & County \\
\hline \multirow{12}{*}{ Permian } & \multirow{12}{*}{$\begin{array}{l}\text { Lower } \\
\text { Permian }\end{array}$} & & $\begin{array}{l}\text { Chase } \\
\text { Group }\end{array}$ & $\begin{array}{l}\text { Wreford } \\
\text { Limestone }\end{array}$ & $25-35$ & $\begin{array}{l}\text { An upper algal limestone, which } \\
\text { weathers to a pitted surface, a shaly } \\
\text { limestone zone, and a lower cherty } \\
\text { limestone-all separated by limy } \\
\text { shale in middle. }\end{array}$ & $\begin{array}{l}\text { Yields small to moderate quantities of } \\
\text { hard water to wells, principally } \\
\text { from weathered and fractured } \\
\text { zones. }\end{array}$ & $\begin{array}{l}\text { Butler, } \\
\quad \text { Cowley }\end{array}$ \\
\hline & & & \multirow{11}{*}{$\begin{array}{l}\text { Council } \\
\text { Grove } \\
\text { Group }\end{array}$} & Speiser Shale & $25-35$ & $\begin{array}{l}\text { Shale; locally, a sandstone is present in } \\
\text { the lower middle part. }\end{array}$ & $\begin{array}{l}\text { Sandstone may yield small quantities } \\
\text { of water to wells locally. Little or } \\
\text { no water is obtained from shale. }\end{array}$ & $\begin{array}{l}\text { Butler, } \\
\quad \text { Cowley }\end{array}$ \\
\hline & & & & $\begin{array}{l}\text { Funston } \\
\text { Limestone }\end{array}$ & $9-12$ & $\begin{array}{l}\text { Limestone at top; shale and limestone } \\
\text { in middle part; and dense limestone } \\
\text { at base. }\end{array}$ & Yields little or no water to wells. & $\begin{array}{l}\text { Butler, } \\
\quad \text { Cowley }\end{array}$ \\
\hline & & & & Blue Rapids Shale & $17-22$ & $\begin{array}{l}\text { Shale in upper part; a thin limestone in } \\
\text { the middle part; shale in lower part. }\end{array}$ & Yields little or no water to wells. & $\begin{array}{l}\text { Butler, } \\
\text { Cowley }\end{array}$ \\
\hline & & & & Crouse Limestone & $8-12$ & $\begin{array}{l}\text { An upper and a lower limestone bed } \\
\text { separated by a thin shaly limestone } \\
\text { bed. Upper and lower beds contain } \\
\text { some chert. }\end{array}$ & $\begin{array}{l}\text { Not a good aquifer but locally yields } \\
\text { small quantities of hard water to } \\
\text { wells. }\end{array}$ & $\begin{array}{l}\text { Butler, } \\
\text { Cowley }\end{array}$ \\
\hline & & & & Easly Creek Shale & $10-15$ & Mostly shale. & Yields no water to wells in the area. & $\begin{array}{l}\text { Butler, } \\
\text { Cowley }\end{array}$ \\
\hline & & & & Bader Limestone & $15-30$ & Limestone, separated by shale. & $\begin{array}{l}\text { Locally yields small quantities of hard } \\
\text { water to wells and springs. }\end{array}$ & $\begin{array}{l}\text { Butler, } \\
\text { Cowley }\end{array}$ \\
\hline & & & & Stearns Shale & $6-10$ & Shale, limy in parts. & Yields no water to wells. & $\begin{array}{l}\text { Butler, } \\
\text { Cowley }\end{array}$ \\
\hline & & & & Beattie Limestone & $10-25$ & $\begin{array}{l}\text { Limestone, separated by limy shale } \\
\text { that contains numerous fossils. }\end{array}$ & $\begin{array}{l}\text { Yields very small quantities of hard } \\
\text { water to a few wells and springs. } \\
\text { Supplies are generally inadequate. }\end{array}$ & $\begin{array}{l}\text { Butler, } \\
\quad \text { Cowley }\end{array}$ \\
\hline & & & & Eskridge Shale & $20-35$ & Shale; contains numerous fossils. & Yields little or no water to wells. & $\begin{array}{l}\text { Butler, } \\
\text { Cowley }\end{array}$ \\
\hline & & & & $\begin{array}{l}\text { Grenola } \\
\text { Limestone }\end{array}$ & $35-55$ & Limestone separated by limy shale. & $\begin{array}{l}\text { Yields small to moderate quantities of } \\
\text { hard water to wells and springs } \\
\text { locally. }\end{array}$ & $\begin{array}{l}\text { Butler, } \\
\text { Cowley }\end{array}$ \\
\hline & & & & Roca Shale & $10-15$ & Shale, limy in part. & Yields no water to wells. & $\begin{array}{l}\text { Butler, } \\
\quad \text { Cowley }\end{array}$ \\
\hline
\end{tabular}


Table 2. Generalized geohydrologic section for Butler, Cowley, Sedgwick, and Sumner Counties, south-central Kansas.-Continued

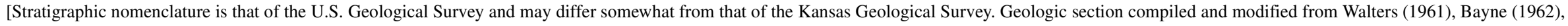
Lane and Miller (1965a), and Aber (1993). Shading indicates those units included in the alluvial aquifer as described in this report. gal/min, gallons per minute; \pm , plus or minus]

\begin{tabular}{|c|c|c|c|c|c|c|c|c|}
\hline System & Series & Subseries & $\begin{array}{l}\text { Stage or } \\
\text { group }\end{array}$ & Stratigraphic unit & $\begin{array}{l}\text { Thickness } \\
\text { (feet) }\end{array}$ & Physical characteristics & Water-supply characteristics & County \\
\hline \multirow{6}{*}{ Permian } & \multirow{6}{*}{$\begin{array}{l}\text { Lower } \\
\text { Permian }\end{array}$} & & \multirow{3}{*}{$\begin{array}{l}\text { Council } \\
\text { Grove } \\
\text { Group }\end{array}$} & $\begin{array}{l}\text { Red Eagle } \\
\text { Limestone }\end{array}$ & 20 & $\begin{array}{l}\text { Limestone, upper part massive; middle } \\
\text { part, thin-bedded limestone layers } \\
\text { separated by very thin shale part- } \\
\text { ings; lower part very thin lime- } \\
\text { stone, which may be absent locally. }\end{array}$ & $\begin{array}{l}\text { Locally may yield small quantities of } \\
\text { hard water to wells from weathered } \\
\text { upper part of unit near the outcrop. }\end{array}$ & $\begin{array}{l}\text { Butler, } \\
\text { Cowley }\end{array}$ \\
\hline & & & & Johnson Shale & $20-30$ & $\begin{array}{l}\text { Varicolored shale, limy to very limy in } \\
\text { lower part. }\end{array}$ & Yields no water to wells. & Cowley \\
\hline & & & & Foraker Limestone & $40-55$ & $\begin{array}{l}\text { Limestone in upper part. Lower part } \\
\text { contains dense cherty limestone } \\
\text { separated by shale. }\end{array}$ & $\begin{array}{l}\text { Locally, yields small to moderate } \\
\text { quantities of hard water to wells } \\
\text { and springs. }\end{array}$ & Cowley \\
\hline & & & \multirow{3}{*}{$\begin{array}{l}\text { Admire } \\
\text { Group }\end{array}$} & Janesville Shale & $55-65$ & $\begin{array}{l}\text { Two shale units separated by lime- } \\
\text { stone. }\end{array}$ & \multirow{3}{*}{$\begin{array}{l}\text { Generally a poor aquifer; locally may } \\
\text { yield small quantities of hard water } \\
\text { from channel sandstone and from } \\
\text { limestone. Locally, seeps may } \\
\text { occur in shale. }\end{array}$} & Cowley \\
\hline & & & & $\begin{array}{l}\text { Falls City } \\
\text { Limestone }\end{array}$ & $3-5$ & Dense limestone. & & Cowley \\
\hline & & & & Onaga Shale & $50-65$ & Shale, separated by limestone. & & Cowley \\
\hline \multirow{6}{*}{$\begin{array}{l}\text { Pennsyl- } \\
\text { vanian }\end{array}$} & \multirow{6}{*}{$\begin{array}{l}\text { Upper Penn- } \\
\text { sylvanian }\end{array}$} & & \multirow{6}{*}{$\begin{array}{l}\text { Wabaunsee } \\
\text { Group }\end{array}$} & $\begin{array}{l}\text { Wood Siding } \\
\text { Formation }\end{array}$ & $40-50$ & $\begin{array}{l}\text { Three limestone beds separated by } \\
\text { shale that is locally sandy. }\end{array}$ & $\begin{array}{l}\text { Generally a poor aquifer, but locally } \\
\text { may yield small quantities of water } \\
\text { of poor quality from sandy shale. }\end{array}$ & Cowley \\
\hline & & & & Root Shale & $50-70$ & $\begin{array}{l}\text { Shale separated by dense limestone. } \\
\text { Locally contains sandstone in } \\
\text { upper part. }\end{array}$ & $\begin{array}{l}\text { Generally a poor aquifer. Locally } \\
\text { small quantities of water of poor } \\
\text { quality are obtained from sandstone } \\
\text { in upper part. }\end{array}$ & Cowley \\
\hline & & & & Stotler Limestone & $15-25$ & Limestone separated by shale. & $\begin{array}{l}\text { Generally a poor aquifer, but in places } \\
\text { small quantities of water of poor } \\
\text { quality may be obtained from } \\
\text { weathered part of lower unit. }\end{array}$ & Cowley \\
\hline & & & & $\begin{array}{l}\text { Pillsbury and } \\
\text { Willard Shales }\end{array}$ & $10-15$ & $\begin{array}{l}\text { Varicolored shale. A persistent impure } \\
\text { limestone occurs below the middle } \\
\text { part; coal commonly occurs near } \\
\text { top and bottom of the formation. }\end{array}$ & $\begin{array}{l}\text { Locally yield small quantities of water } \\
\text { of poor quality to shallow wells. }\end{array}$ & Cowley \\
\hline & & & & $\begin{array}{l}\text { Emporia } \\
\text { Limestone }\end{array}$ & $20-30$ & $\begin{array}{l}\text { Limestone separated by shale. Shale } \\
\text { commonly contains coal in upper } \\
\text { part and sandstone in middle part. }\end{array}$ & $\begin{array}{l}\text { Small quantities of water of good to } \\
\text { poor quality available, principally } \\
\text { from the sandstone in the shale. }\end{array}$ & Cowley \\
\hline & & & & Auburn Shale & $5-10$ & $\begin{array}{l}\text { Shale, locally contains thin limestone } \\
\text { beds. }\end{array}$ & Yields little or no water to wells. & Cowley \\
\hline
\end{tabular}




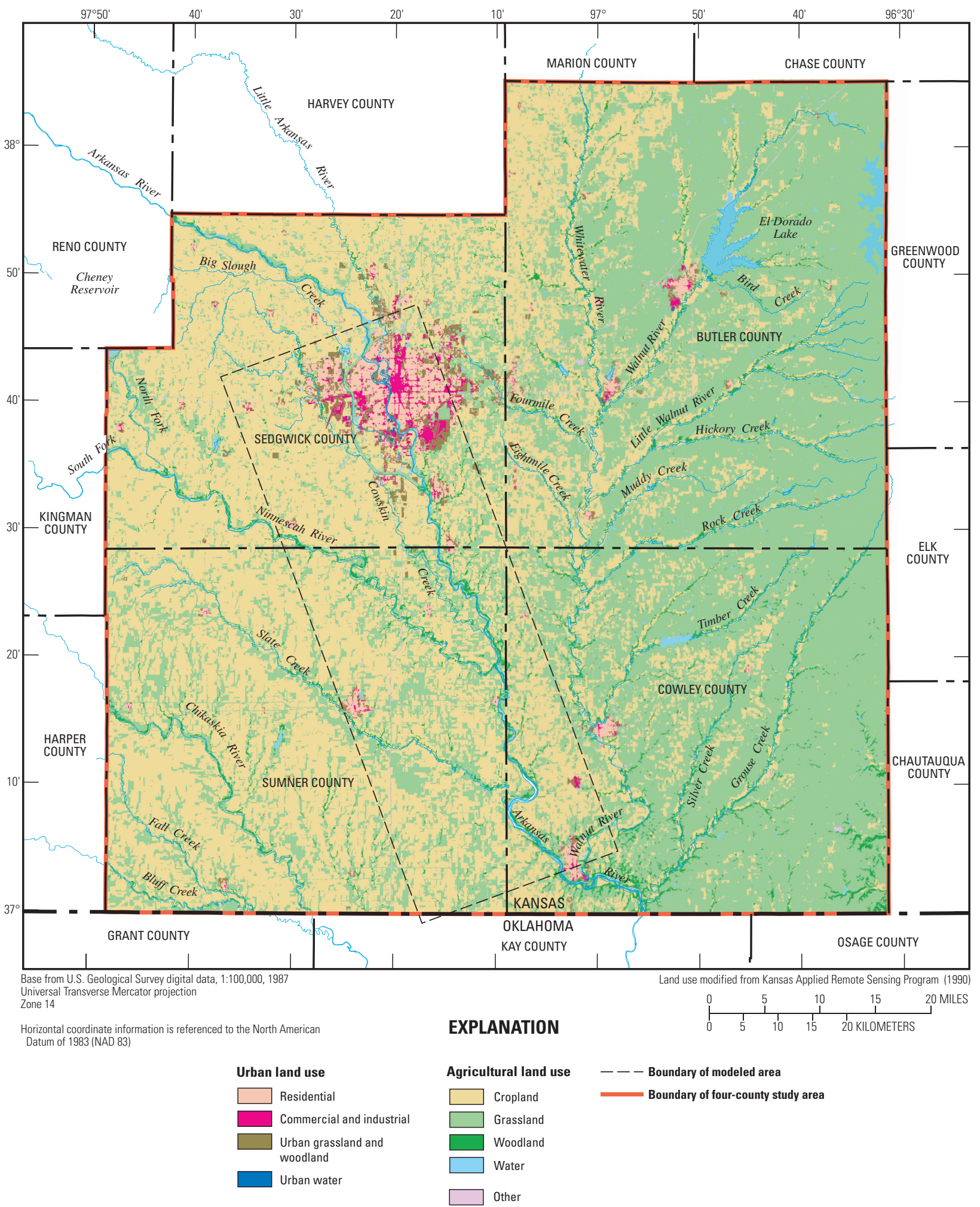

Figure 10. Land use in study area, 1990 (from Kansas Applied Remote Sensing Program, 1990). 
Table 3. Land use in Butler, Cowley, Sedgwick, and Sumner Counties, south-central Kansas, 1990.

[Land-use data from Kansas Applied Remote Sensing Program, 1990]

\begin{tabular}{|c|c|c|c|c|}
\hline $\begin{array}{l}\text { Land-use classification } \\
\text { (fig. 10) }\end{array}$ & $\begin{array}{l}\text { Butler } \\
\text { County }\end{array}$ & Cowley County & $\begin{array}{l}\text { Sedgwick } \\
\text { County }\end{array}$ & Sumner County \\
\hline Land area (square miles) & 1,428 & 1,126 & 999 & 1,182 \\
\hline \multicolumn{5}{|c|}{ Percentage of urban land use } \\
\hline Residential & .52 & .48 & 5.90 & .33 \\
\hline Commercial and (or) industrial & .16 & .17 & 2.71 & .06 \\
\hline Urban grassland & .36 & .16 & 3.61 & .18 \\
\hline Urban woodland & 0 & 0 & .09 & 0 \\
\hline Urban water & .01 & .01 & .13 & 0 \\
\hline Total urban land-use percentage & $\mathbf{1 . 0 5}$ & .82 & 12.44 & .57 \\
\hline Percentage of urban land use for study area & 3.28 & & & \\
\hline
\end{tabular}

Percentage of agricultural land use

$\begin{array}{lrrrr}\text { Cropland } & 30.43 & 25.96 & 69.22 & 67.89 \\ \text { Grassland } & 65.18 & 67.94 & 15.67 & 29.12 \\ \text { Woodland } & 1.64 & 4.07 & 1.38 & 2.02 \\ \text { Total agricultural land-use percentage } & \mathbf{9 7 . 2 5} & \mathbf{9 7 . 9 7} & \mathbf{8 6 . 2 7} & \mathbf{9 9 . 0 3} \\ \text { Percentage of agricultural land use for study area } & \mathbf{9 5 . 5 5} & & & \end{array}$

Percentage of other land use

\begin{tabular}{lrrrr} 
Water & 1.44 & 1.03 & 1.03 & .25 \\
Other & .26 & .18 & .27 & .15 \\
\cline { 2 - 6 } Total other land-use percentage & $\mathbf{1 . 7 0}$ & $\mathbf{1 . 2 1}$ & $\mathbf{1 . 3 0}$ & $\mathbf{. 4 0}$ \\
Percentage of other land use for study area & $\mathbf{1 . 1 7}$ & & & \\
\hline
\end{tabular}

\section{Water Use}

Water resources in Butler, Cowley, Sedgwick, and Sumner Counties are used for public, irrigation, thermoelectric power generation, industrial, and self-supplied domestic supplies. Estimated water use for 1990, 1995, and 2000 (U.S. Geological Survey, 2003) is presented in table 4.

Public supply used 43 percent of the water withdrawn in the four-county area in 1990 and that percentage increased to 53 percent in 2000 (fig. 11). Sumner County was the only county in the study area that consistently used more of its water for irrigation than for public supply (table 4). The majority of the water used in the four-county area came from ground-water supplies, with ground water providing 68 percent of the water used in 1990, 67 percent in 1995, and 58 percent in 2000

(fig. 11). The apparent decreasing reliance on ground water as a source of supply in the study area most likely is due to increasing reliance by Sedgwick County and, Wichita in particular, on Cheney Reservoir as a source of public supply (Hansen and Aucott, 2004). Approximately 76 percent of the water withdrawn from the four-county study area during 1990-2000 was withdrawn from Sedgwick County. Water use varies from year to year as a result of many factors including changes in precipitation, population, and especially irrigation pumpage.
Ground-water use reported to the Kansas Department of Agriculture, Division of Water Resources (DWR) (written commun., 2003), for 1998-2001 was summarized for the modeled area (table 5). Irrigation and municipal uses accounted for an average of 36 and 28 percent, respectively, of the total ground-water use in the modeled area during 1998-2001. Much of this water use is concentrated in Sedgwick County. Water use that is authorized or permitted by DWR (about $68 \mathrm{Mgal} / \mathrm{d}$ ) is almost twice the 1998-2001 average reported use (about $36 \mathrm{Mgal} / \mathrm{d})$.

\section{Water Quality}

Unsuitable water quality can restrict some uses of a water resource. Ground- and surface-water-quality issues, especially elevated chloride concentrations, have been identified in the study area by previous investigators (Gogel, 1981). An inventory of historic ground- and surface-water-quality analyses for the four-county study area was compiled from the USGS QWDATA database, and water-quality samples were collected during August 2003 from 30 wells and 10 surface-water sites in and near the modeled area (fig. 12) to help further define water quality in the alluvial aquifer. 
Table 4. Estimated water use in Butler, Cowley, Sedgwick, and Sumner Counties, south-central Kansas, during 1990, 1995, and 2000.

[Water-use data and population served from U.S. Geological Survey (2003). Mgal/d; million gallons per day]

\begin{tabular}{|c|c|c|c|}
\hline \multirow{2}{*}{$\begin{array}{c}\text { Use } \\
\text { (population served) }\end{array}$} & \multicolumn{3}{|c|}{ Estimated water use (Mgal/d) } \\
\hline & $\begin{array}{l}\text { Ground } \\
\text { water }\end{array}$ & $\begin{array}{c}\text { Surface } \\
\text { water }\end{array}$ & Total \\
\hline \multicolumn{4}{|c|}{ Butler County } \\
\hline \multicolumn{4}{|l|}{1990} \\
\hline Public supplies $(37,020)$ & 0.08 & 7.63 & 7.71 \\
\hline Irrigation & .13 & 1.14 & 1.27 \\
\hline Thermoelectric power generation & 0 & 0 & 0 \\
\hline Industrial & .07 & .17 & .24 \\
\hline Domestic, self supplied $(13,560)$ & 1.22 & 0 & 1.22 \\
\hline All other uses & .86 & 1.66 & 2.52 \\
\hline Total for 1990 & 2.36 & 10.60 & 12.96 \\
\hline \multicolumn{4}{|l|}{1995} \\
\hline Public supplies $(41,440)$ & .12 & 8.42 & 8.54 \\
\hline Irrigation & .04 & .61 & .65 \\
\hline Thermoelectric power generation & 0 & 0 & 0 \\
\hline Industrial & 0 & .22 & .22 \\
\hline Domestic, self supplied $(16,310)$ & 1.35 & 0 & 1.35 \\
\hline All other uses & 1.70 & .36 & 2.06 \\
\hline Total for 1995 & 3.21 & 9.61 & 12.82 \\
\hline \multicolumn{4}{|l|}{2000} \\
\hline Public supplies $(44,380)$ & .14 & 10.07 & 10.21 \\
\hline Irrigation & .12 & 1.06 & 1.18 \\
\hline Thermoelectric power generation & 0 & 0 & 0 \\
\hline Industrial & .01 & .03 & .04 \\
\hline Domestic, self supplied $(15,100)$ & 1.07 & 0 & 1.07 \\
\hline All other uses & .37 & 1.70 & 2.07 \\
\hline Total for 2000 & 1.71 & 12.86 & 14.57 \\
\hline \multicolumn{4}{|c|}{ Cowley County } \\
\hline \multicolumn{4}{|l|}{1990} \\
\hline Public supplies $(33,400)$ & 4.10 & 2.33 & 6.43 \\
\hline Irrigation & .75 & .55 & 1.30 \\
\hline Thermoelectric power generation & 0 & 0 & 0 \\
\hline Industrial & 1.08 & 0 & 1.08 \\
\hline Domestic, self supplied $(3,520)$ & .34 & 0 & .34 \\
\hline All other uses & 1.78 & .40 & 2.18 \\
\hline Total for 1990 & 8.05 & 3.28 & 11.33 \\
\hline \multicolumn{4}{|l|}{1995} \\
\hline Public supplies $(32,740)$ & 3.37 & 2.00 & 5.37 \\
\hline Irrigation & .46 & .32 & .78 \\
\hline Thermoelectric power generation & 0 & 0 & 0 \\
\hline Industrial & .96 & 0 & .96 \\
\hline Domestic, self supplied $(4,370)$ & .38 & 0 & .38 \\
\hline All other uses & 1.54 & .56 & 2.10 \\
\hline Total for 1995 & 6.71 & 2.88 & 9.59 \\
\hline
\end{tabular}


Table 4. Estimated water use in Butler, Cowley, Sedgwick, and Sumner Counties, south-central Kansas, during 1990, 1995, and 2000.-Continued

[Water-use data and population served from U.S. Geological Survey (2003). Mgal/d; million gallons per day]

\begin{tabular}{|c|c|c|c|}
\hline \multirow{2}{*}{$\begin{array}{c}\text { Use } \\
\text { (population served) }\end{array}$} & \multicolumn{3}{|c|}{ Estimated water use (Mgal/d) } \\
\hline & $\begin{array}{l}\text { Ground } \\
\text { water }\end{array}$ & $\begin{array}{c}\text { Surface } \\
\text { water }\end{array}$ & Total \\
\hline \multicolumn{4}{|c|}{ Cowley County-Continued } \\
\hline \multicolumn{4}{|l|}{2000} \\
\hline Public supplies $(33,560)$ & 2.53 & 2.37 & 4.90 \\
\hline Irrigation & .44 & .79 & 1.23 \\
\hline Thermoelectric power generation & 0 & 0 & 0 \\
\hline Industrial & 0 & 0 & 0 \\
\hline Domestic, self supplied $(2,730)$ & .23 & 0 & .23 \\
\hline All other uses & .76 & .90 & 1.66 \\
\hline Total for 2000 & 3.96 & 4.06 & 8.02 \\
\hline \multicolumn{4}{|c|}{ Sedgwick County } \\
\hline \multicolumn{4}{|l|}{1990} \\
\hline Public supplies $(360,400)$ & 14.28 & 25.99 & 40.27 \\
\hline Irrigation & 36.33 & .94 & 37.27 \\
\hline Thermoelectric power generation & 4.35 & 0 & 4.35 \\
\hline Industrial & 7.02 & 0 & 7.02 \\
\hline Domestic, self supplied $(43,260)$ & 3.63 & 0 & 3.63 \\
\hline All other uses & 7.53 & .21 & 7.74 \\
\hline Total for 1990 & 73.14 & 27.14 & 100.28 \\
\hline \multicolumn{4}{|l|}{1995} \\
\hline Public supplies $(375,470)$ & 18.95 & 25.49 & 44.44 \\
\hline Irrigation & 27.01 & .32 & 27.33 \\
\hline Thermoelectric power generation & 4.46 & 0 & 4.46 \\
\hline Industrial & 4.27 & 0 & 4.27 \\
\hline Domestic, self supplied $(43,860)$ & 3.17 & 0 & 3.17 \\
\hline All other uses & 5.46 & .17 & 5.63 \\
\hline Total for 1995 & 63.32 & 25.98 & 89.30 \\
\hline \multicolumn{4}{|l|}{2000} \\
\hline Public supplies $(432,790)$ & 16.81 & 36.93 & 53.74 \\
\hline Irrigation & 32.85 & 1.04 & 33.89 \\
\hline Thermoelectric power generation & 5.86 & 0 & 5.86 \\
\hline Industrial & 4.56 & 0 & 4.56 \\
\hline Domestic, self supplied $(20,080)$ & 1.75 & 0 & 1.75 \\
\hline All other uses & 2.84 & .27 & 3.11 \\
\hline Total for 2000 & 64.67 & 38.24 & 102.91 \\
\hline \multicolumn{4}{|c|}{ Sumner County } \\
\hline \multicolumn{4}{|l|}{1990} \\
\hline Public supplies $(23,700)$ & 2.10 & 1.37 & 3.47 \\
\hline Irrigation & 4.97 & 0 & 4.97 \\
\hline Thermoelectric power generation & 0 & 0 & 0 \\
\hline Industrial & 0 & 0 & 0 \\
\hline Domestic, self supplied $(2,140)$ & .20 & 0 & .20 \\
\hline All other uses & .82 & .19 & 1.01 \\
\hline Total for 1990 & 8.09 & 1.56 & 9.65 \\
\hline
\end{tabular}


Table 4. Estimated water use in Butler, Cowley, Sedgwick, and Sumner Counties, south-central Kansas, during 1990, 1995, and 2000.-Continued

[Water-use data and population served from U.S. Geological Survey (2003). Mgal/d; million gallons per day]

\begin{tabular}{|c|c|c|c|}
\hline \multirow{2}{*}{$\begin{array}{c}\text { Use } \\
\text { (population served) }\end{array}$} & \multicolumn{3}{|c|}{ Estimated water use (Mgal/d) } \\
\hline & $\begin{array}{l}\text { Ground } \\
\text { water }\end{array}$ & $\begin{array}{c}\text { Surface } \\
\text { water }\end{array}$ & Total \\
\hline \multicolumn{4}{|c|}{ Sumner County-Continued } \\
\hline \multicolumn{4}{|l|}{1995} \\
\hline Public supplies $(23,310)$ & 1.77 & 0.74 & 2.51 \\
\hline Irrigation & 3.29 & .01 & 3.30 \\
\hline Thermoelectric power generation & 0 & 0 & 0 \\
\hline Industrial & .01 & 0 & .01 \\
\hline Domestic, self supplied $(3,210)$ & .24 & 0 & .24 \\
\hline All other uses & .80 & .03 & .83 \\
\hline Total for 1995 & 6.11 & .78 & 6.89 \\
\hline \multicolumn{4}{|l|}{2000} \\
\hline Public supplies $(23,910)$ & 1.73 & .95 & 2.68 \\
\hline Irrigation & 5.52 & 0 & 5.52 \\
\hline Thermoelectric power generation & 0 & 0 & 0 \\
\hline Industrial & 0 & 0 & 0 \\
\hline Domestic, self supplied $(2,040)$ & .18 & 0 & .18 \\
\hline All other use & .57 & .06 & .63 \\
\hline Total for 2000 & 8.00 & 1.01 & 9.01 \\
\hline \multicolumn{4}{|c|}{ Totals for study area } \\
\hline \multicolumn{4}{|l|}{1990} \\
\hline Public supplies $(454,520)$ & 20.56 & 37.32 & 57.88 \\
\hline Irrigation & 42.18 & 2.63 & 44.81 \\
\hline Thermoelectric power generation & 4.35 & 0 & 4.35 \\
\hline Industrial & 8.17 & .17 & 8.34 \\
\hline Domestic, self supplied $(62,480)$ & 5.39 & 0 & 5.39 \\
\hline All other uses & 10.99 & 2.46 & 13.45 \\
\hline Total for 1990 & 91.64 & 42.58 & 134.22 \\
\hline \multicolumn{4}{|l|}{1995} \\
\hline Public supplies $(472,960)$ & 24.21 & 36.65 & 60.86 \\
\hline Irrigation & 30.80 & 1.26 & 32.06 \\
\hline Thermoelectric power generation & 4.46 & 0 & 4.46 \\
\hline Industrial & 5.24 & .22 & 5.46 \\
\hline Domestic, self supplied $(67,750)$ & 5.14 & 0 & 5.14 \\
\hline All other uses & 9.50 & 1.12 & 10.62 \\
\hline Total for 1995 & 79.35 & 39.25 & 118.60 \\
\hline \multicolumn{4}{|l|}{2000} \\
\hline Public supplies $(534,640)$ & 21.21 & 50.32 & 71.53 \\
\hline Irrigation & 38.93 & 2.89 & 41.82 \\
\hline Thermoelectric power generation & 5.86 & 0 & 5.86 \\
\hline Industrial & 4.57 & .03 & 4.60 \\
\hline Domestic, self supplied $(39,950)$ & 3.23 & 0 & 3.23 \\
\hline All other uses & 4.54 & 2.93 & 7.47 \\
\hline Total for 2000 & 78.34 & 56.17 & 134.51 \\
\hline
\end{tabular}



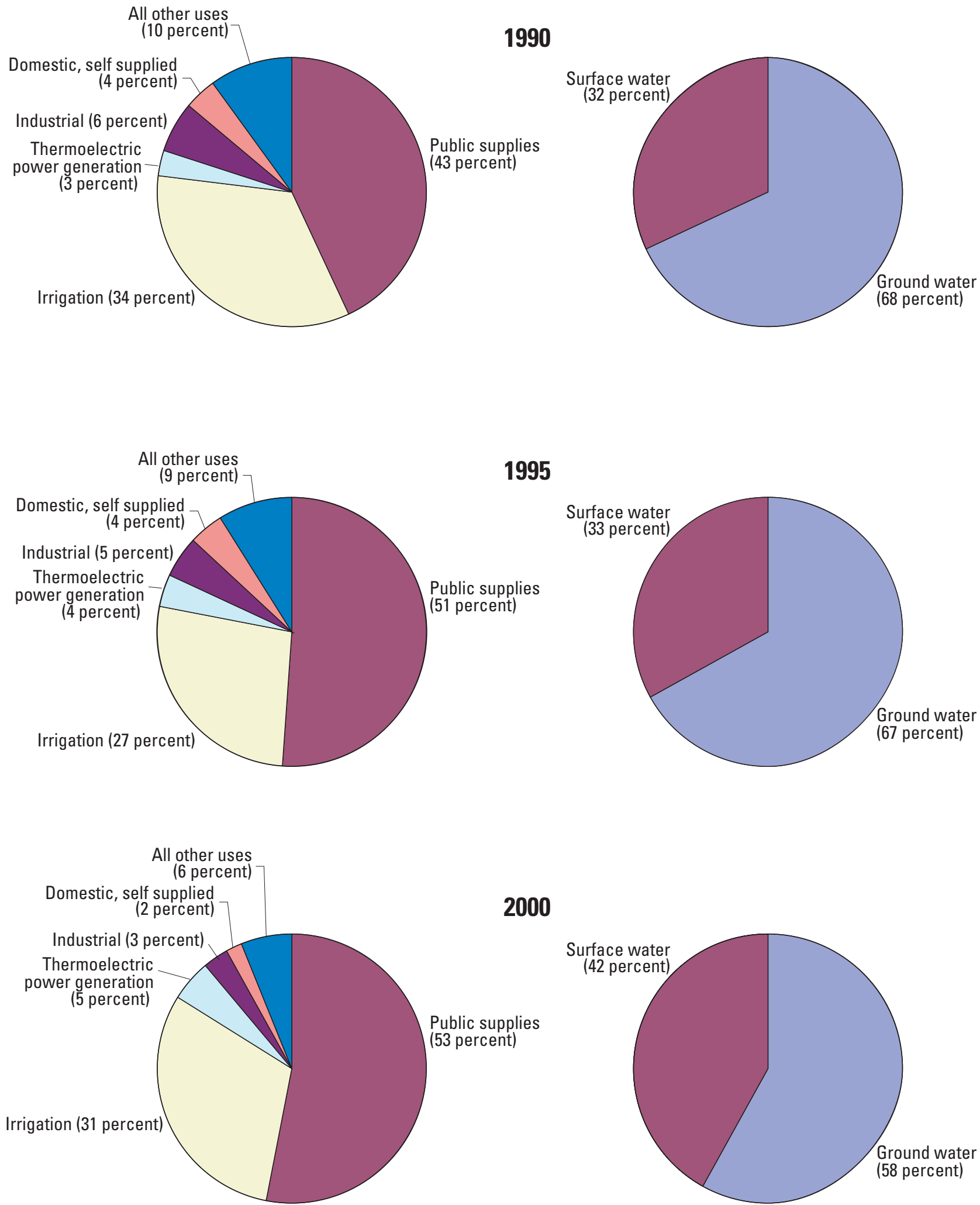

Figure 11. Percentages of water withdrawn from study area, 1990, 1995, and 2000 (data from U.S. Geological Survey, 2003). 
Table 5. Reported ground-water use in modeled area of lower Arkansas River Basin in south-central Kansas for 1998-2001.

[Water-use values reported to Kansas Department of Agriculture, Division of Water Resources, Topeka, Kansas. All values are in million gallons per day; --, not reported]

\begin{tabular}{|c|c|c|c|c|c|}
\hline Water use & 1998 & 1999 & 2000 & 2001 & $\begin{array}{c}\text { Average for } \\
\text { 1998-2001 }\end{array}$ \\
\hline Contamination remediation & 3.39 & 2.99 & 3.92 & 3.01 & 3.33 \\
\hline Dewatering & -- & -- & -- & .17 & .04 \\
\hline Hydraulic dredging & .36 & .45 & .18 & .26 & .31 \\
\hline Industrial uses & 6.62 & 7.89 & 7.13 & 6.24 & 6.97 \\
\hline Irrigation & 13.54 & 10.77 & 12.73 & 15.31 & 13.09 \\
\hline Municipal uses & 11.52 & 9.61 & 11.36 & 8.79 & 10.32 \\
\hline Recreational uses & .75 & 1.28 & 3.71 & 1.44 & 1.79 \\
\hline Thermal exchange & -- & -- & -- & 1.41 & .35 \\
\hline Total & 36.18 & 32.99 & 39.02 & 36.62 & 36.20 \\
\hline
\end{tabular}

Ground-water-quality samples were collected using approved USGS techniques (Wood, 1976). All wells that were sampled were less than $100 \mathrm{ft}$ deep and were completed in unconsolidated deposits. Surface-water quality samples were collected using either a width-integrated approach in the case of a stream or a depth-integrated approach in the case of a surfacewater body (Wilde and others, 1999). The surface-water sampling sites included four sites on the Arkansas River, two sites on the Ninnescah River, one site on Slate Creek, two sand quarries, and one oxbow lake.

All samples were measured onsite for physical properties, including specific conductance, $\mathrm{pH}$, temperature, and alkalinity, using methods described in Wilde and Radtke (1998). Major-ion concentrations (including calcium, magnesium, sodium, sulfate, and chloride) were analyzed at the USGS National Water-Quality Laboratory (NWQL) in Denver, Colorado, using analytical methods described in Fishman and Friedman (1989). Results of the August 2003 water-quality analyses are presented in table 11 in the "Supplemental Information" section at the back of this report.

The natural water-quality characteristics of ground water generally are functions of the mineralogy of the geologic formations containing the water and of the duration of contact between the water and minerals (Bevans, 1989). The natural water-quality characteristics of surface water generally are a function of water volume, water velocity, surface runoff, ground-water contributions, and point- and nonpoint-source contributions. Data obtained through a search of the USGS QWDATA database for results of ground- and surface-waterquality analyses were used to give an overall picture of the historical quality of water in the four-county area. Of specific interest were dissolved solids, chloride, and sulfate concentrations as these water-quality constituents have been identified in previous studies as being particularly problematic (see references cited in "Previous Studies" section) for the study area.

\section{Dissolved Solids}

In general, water from consolidated bedrock formations in the four-county area (specifically the Wellington Formation and Ninnescah Shale) is more mineralized than water from the shallower unconsolidated deposits (specifically alluvial and terrace deposits), and concentrations of dissolved solids generally increase with depth as the duration of contact between the water and the minerals increases (Bevans, 1989, p. 82). Unconsolidated deposits generally have few readily soluble minerals; they are recharged rapidly by precipitation and transmit ground water at a faster rate than bedrock. However, water from unconsolidated deposits generally is more susceptible to larger concentrations of dissolved solids.

The U.S. Environmental Protection Agency (2003) has established a nonenforceable guideline (Secondary Drinking Water Regulation, SDWR) of $500 \mathrm{mg} / \mathrm{L}$ for dissolved solids in drinking water. SDWRs regulate contaminants that may cause cosmetic effects (such as skin or tooth discoloration) or aesthetic effects (such as taste, odor, or color) in drinking water. Water containing more than $500 \mathrm{mg} / \mathrm{L}$ dissolved solids is likely to contain enough of certain constituents to cause noticeable taste or odor issues or otherwise make the water undesirable or unsuitable for some uses.

A map showing historical dissolved-solids concentrations in water from wells in the four-county study area is shown in figure 13A. The map is based on results of analyses from 926 ground-water samples with historical concentrations ranging from 7.0 to $31,600 \mathrm{mg} / \mathrm{L}$ and a median dissolved-solids concentration of $825 \mathrm{mg} / \mathrm{L}$. Twenty-nine percent of the samples contained dissolved-solids concentrations that were $500 \mathrm{mg} / \mathrm{L}$ or less.

Historical dissolved-solids concentrations in water from wells in Butler County were generally larger in water from the unconsolidated deposits along the Whitewater and Walnut Rivers than in water from upland areas of the county (fig. 13A). In Cowley County, Bayne (1962, table 6) reported dissolved solids in 57 ground-water samples in concentrations ranging from 


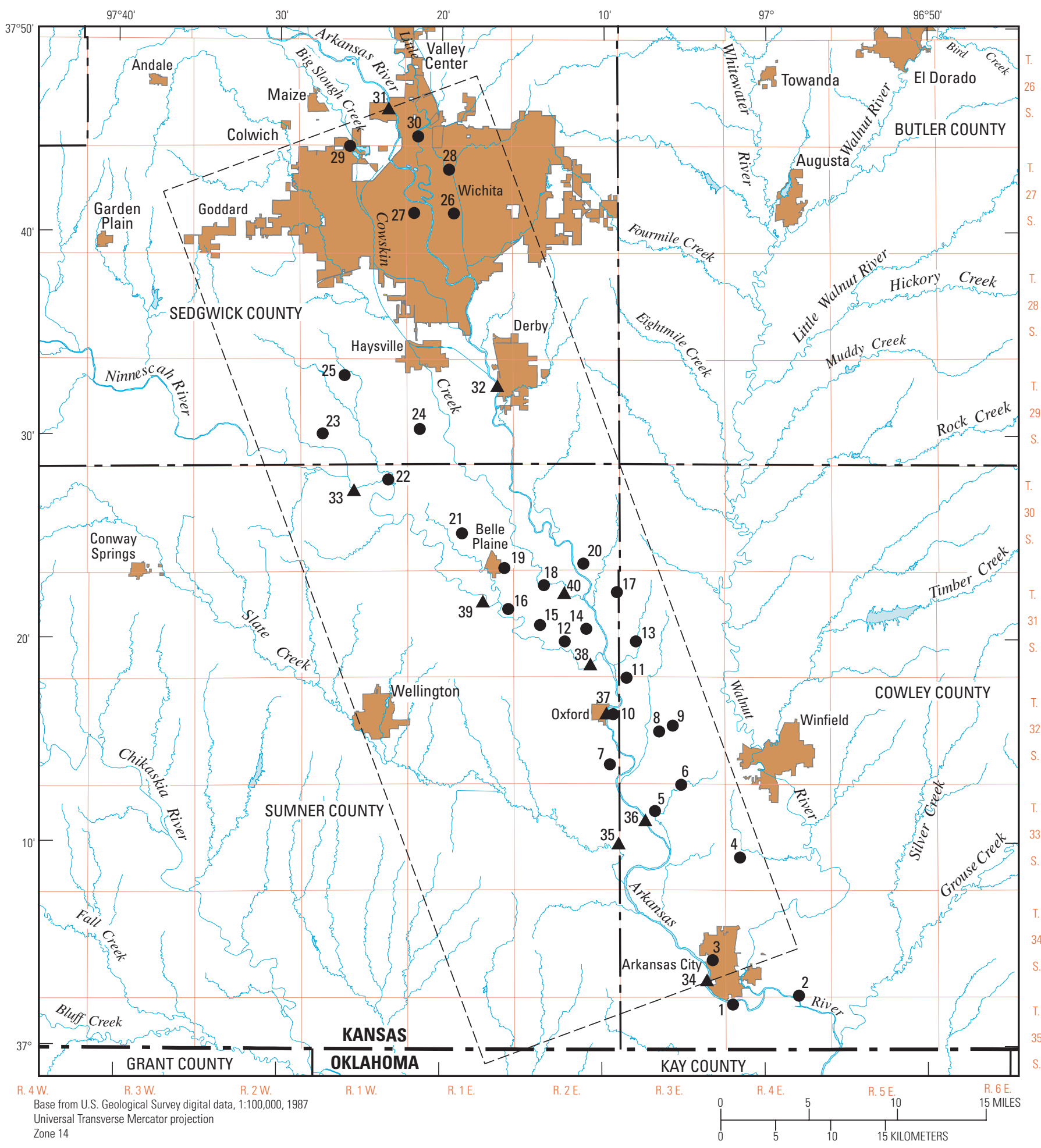

Horizontal coordinate information is referenced to the North American Datum of 1983 (NAD 83)

EXPLANATION

Ground-water-quality sampling site and map number

${ }^{34} \Delta$ Surface-water-quality sampling site and map number

Boundary of modeled area

Figure 12. Location of ground- and surface-water sites where water-quality samples were collected during August 2003 in and near modeled area. 
269 to $28,000 \mathrm{mg} / \mathrm{L}$. Dissolved-solids concentrations in water from consolidated bedrock formations ranged from 290 to $2,670 \mathrm{mg} / \mathrm{L}$, and in water from unconsolidated deposits, dissolved-solids concentrations ranged from 269 to $28,000 \mathrm{mg} / \mathrm{L}$. Figure $13 \mathrm{~A}$ shows larger historical dissolved-solids concentrations in water from wells in the unconsolidated deposits along the Arkansas River in Cowley County than in upland areas.

In Sedgwick County, water from the Wellington Formation is generally either a calcium sulfate, a calcium bicarbonate sulfate, or a calcium bicarbonate type. Calcium and bicarbonate are derived from the dissolution of impure limestone beds that occur in this formation. Calcium and sulfate are derived from the dissolution of gypsum and anhydrite beds. The calcium sulfate type water from the Wellington Formation generally contains dissolved-solids concentrations that exceed 1,000 mg/L; the calcium bicarbonate sulfate type water has dissolved-solids concentrations ranging from 500 to $1,000 \mathrm{mg} / \mathrm{L}$; and calcium bicarbonate type water has concentrations of dissolved solids that are generally less than $500 \mathrm{mg} / \mathrm{L}$ (Bevans, 1989).

Water from the Ninnescah Shale in Sedgwick County is generally less mineralized than water from the Wellington Formation because the Ninnescah Shale does not contain as many readily soluble minerals and because the occurrence of unconsolidated deposits overlying the Ninnescah Shale improves recharge conditions and probably allows dilution of water in the bedrock (Lane and Miller, 1965a). Shallow wells in the upper weathered part of the Ninnescah Shale yield calcium bicarbonate water, with dissolved-solids concentrations less than $1,000 \mathrm{mg} / \mathrm{L}$. Mineralization of water increases with depth in the Ninnescah Shale, and where thin beds of gypsum are encountered, the water is a calcium sulfate type, with concentrations of dissolved solids often exceeding 1,000 mg/L (Bevans, 1989).

Lower Pleistocene (undifferentiated pre-Illinoisan age) deposits that occur in upland areas north of the Ninnescah River yield calcium bicarbonate type water, with less than $500 \mathrm{mg} / \mathrm{L}$ dissolved solids. Alluvium and terrace deposits of Wisconsin to Holocene age also occur in the Ninnescah River Valley, but water-quality data are sparse. The Ninnescah River is a gaining stream throughout its reach, and water in the alluvium may be similar to that in adjacent bedrock, probably calcium sulfate or calcium bicarbonate type water with less than $1,000 \mathrm{mg} / \mathrm{L}$ dissolved solids. Large-capacity wells could induce infiltration of stream water into the alluvium and yield sodium chloride type water with less than 1,000 mg/L (Bevans, 1989).

Water in alluvium and terrace deposits of Wisconsinan to Holocene age in the Little Arkansas River valley north of Wichita generally is a calcium bicarbonate type, with generally less than $500 \mathrm{mg} / \mathrm{L}$ dissolved solids. In northern Wichita, these same deposits contain sodium calcium chloride bicarbonate type water, with concentrations of dissolved solids exceeding $500 \mathrm{mg} / \mathrm{L}$ or sodium chloride type water, with concentrations of dissolved solids exceeding 1,000 mg/L (fig. 13A). South of Wichita, alluvium and terrace deposits contain calcium bicarbonate water, with concentrations of dissolved solids less than 1,000 mg/L and locally less than $500 \mathrm{mg} / \mathrm{L}$ (Bevans, 1989).
In Sumner County, historical dissolved-solids concentrations were generally larger in the unconsolidated deposits along the major streams than in upland areas (fig. 13A). Walters (1961, table 6) reported dissolved solids in 67 ground-water samples in concentrations ranging from 146 to about $158,400 \mathrm{mg} / \mathrm{L}$. Dissolved-solids concentrations in water from consolidated bedrock formations ranged from 573 to $3,360 \mathrm{mg} / \mathrm{L}$ for the Wellington Formation and from 295 to 2,670 $\mathrm{mg} / \mathrm{L}$ for the Ninnescah Shale (Walters, 1961, table 6). Dissolved-solids concentrations in water from unconsolidated deposits ranged from 146 to $158,400 \mathrm{mg} / \mathrm{L}$. Walters (1961) attributed the larger concentrations of dissolved solids in unconsolidated deposits of Sumner County to oilfield-brine contamination.

The results of analyses for dissolved solids in the August 2003 water-quality samples from 30 ground-water sites and 10 surface-water sites are shown in figure $13 B$ and listed in table 11 at the back of this report. Forty percent of the samples collected from the ground-water sites contained dissolvedsolids concentrations that exceeded the SDWR, and 80 percent of the surface-water samples had dissolved-solids concentrations that exceeded the SDWR. Dissolved-solids concentrations in the August 2003 ground-water samples ranged from 216 to $1,100 \mathrm{mg} / \mathrm{L}$ and are larger in the Wichita area and near and downstream from the confluence of the Ninnescah and Arkansas Rivers (fig. 13B). Dissolved-solids concentrations in the August 2003 surface-water samples ranged from 318 (sand quarry near Oxford, map number 37) to 4,340 mg/L (Slate Creek, map number 35) and were largest in samples from the upstream end of the modeled area, the downstream reach of Slate Creek, and the oxbow lake near Belle Plaine (map number 39, fig. 13B). Dissolved-solids concentrations were smallest (318 and $368 \mathrm{mg} / \mathrm{L}$ ) in samples from the two sand quarries (map numbers 37 and 40, respectively, fig. 13B). The two sandquarry dissolved-solids concentrations probably reflect the ground-water contribution to the quarries.

\section{Chloride}

Chloride ions are very abundant in nature. They are found in quantity in sea water (19,000 mg/L; Hem, 1992) and oilfield brines and are dissolved in small quantities as sodium chloride from many rock materials. Two natural sources of chloride and one artificial source (resulting from human activities) affect ground-water quality in the four-county study area. The two natural sources of chloride are the Arkansas River and saline ground water from the Wellington Formation (Gogel, 1981). The artificial source of chloride is brine from oilfield activities. Chloride has little effect on the suitability of water for ordinary use unless present in sufficient quantity to make the water unpotable or corrosive. Chloride concentrations less than $250 \mathrm{mg} / \mathrm{L}$ cannot be detected by taste; water containing between 250 and $500 \mathrm{mg} / \mathrm{L}$ chloride may have a slightly salty taste but can be used for drinking and household uses; and water containing more than $500 \mathrm{mg} / \mathrm{L}$ has a disagreeable taste but 


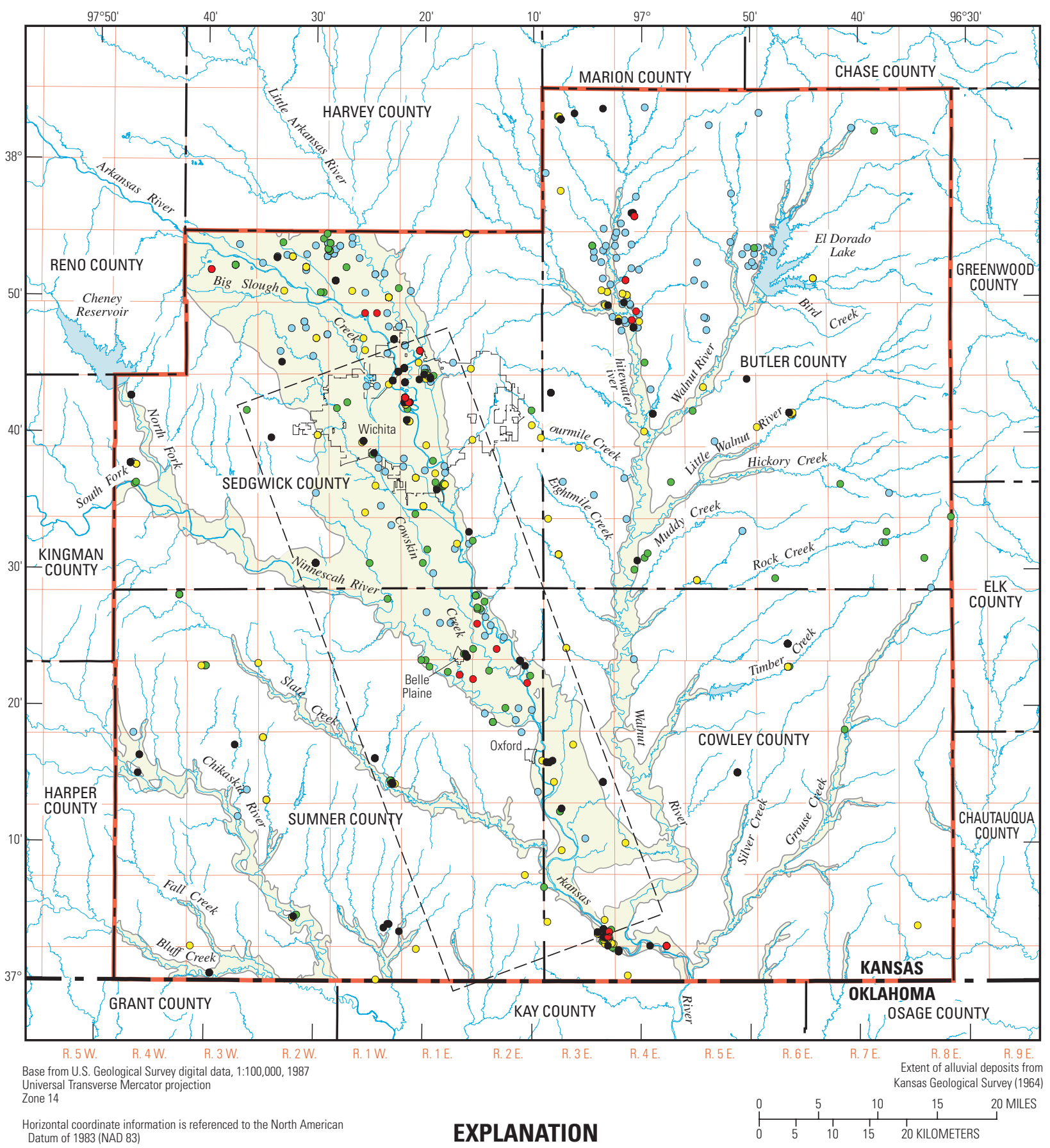

Alluvial deposits

\begin{tabular}{|c|c|}
\hline $0-250$ & - 1,001-2,000 \\
\hline 251-500 & - Greater than 2,000 \\
\hline $501-1,000$ & Not determined \\
\hline
\end{tabular}

Boundary of modeled area

Boundary of four-county study area

Figure 13. (A) Historical dissolved-solids concentrations in water from wells in the four-county study area (data from U.S. Geological Survey OWDATA database). 


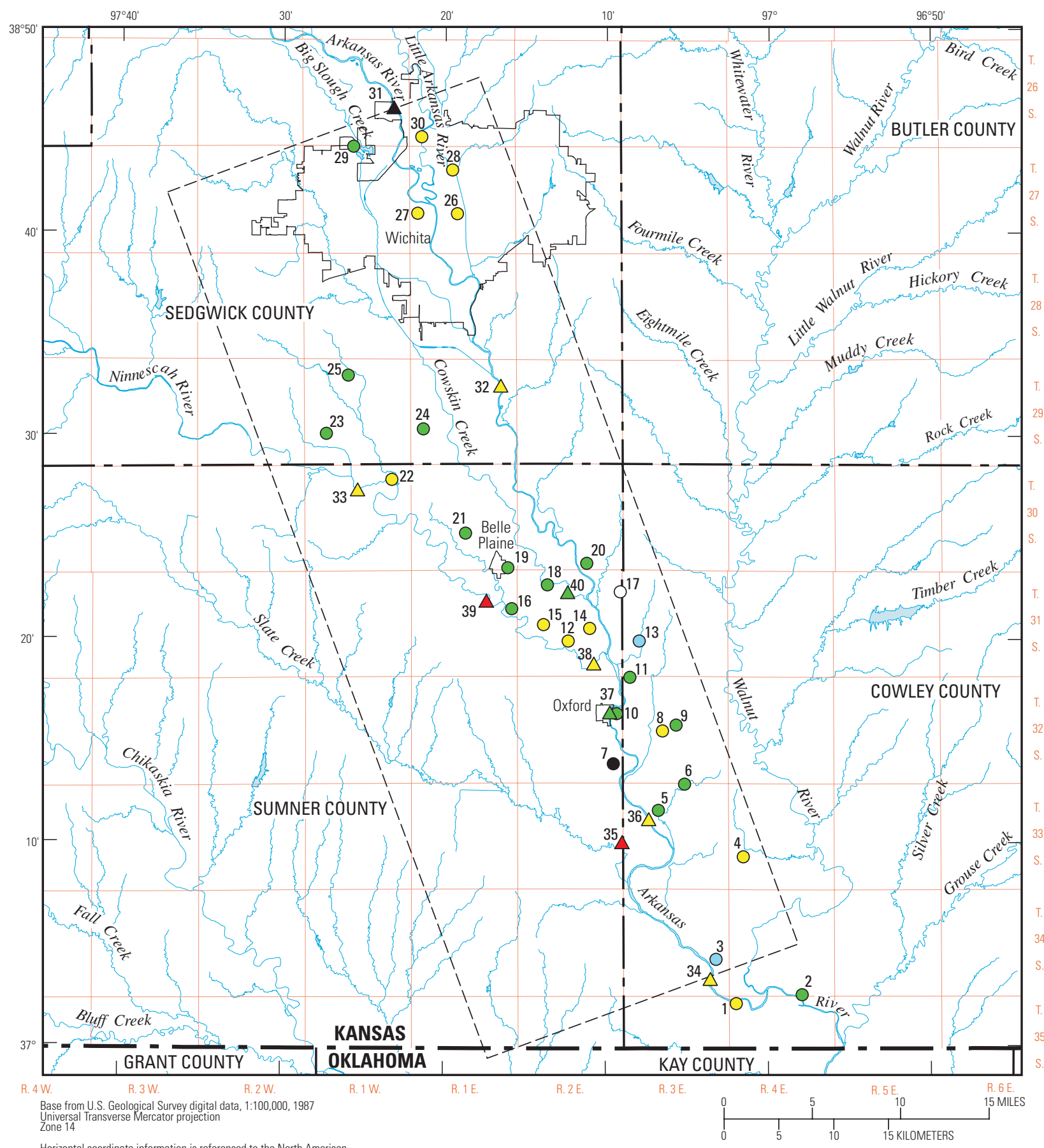

Horizontal coordinate information is referenced to the North American
Datum of 1983 (NAD 83)

EXPLANATION

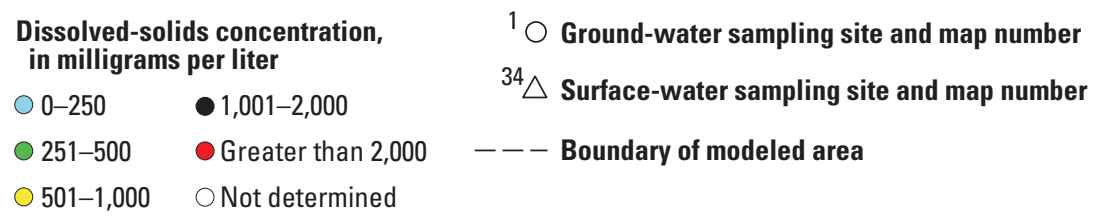

Figure 13. (B) Dissolved-solids concentrations in ground- and surface-water samples collected from modeled area, August 2003. 
ordinarily causes no health effects until much larger concentrations are present. Chloride concentrations greater than $350 \mathrm{mg} / \mathrm{L}$ can be harmful to crops (Bauder, 2000). Because of the salty taste and corrosive potential, the U.S. Environmental Protection Agency (2003) has established a nonenforceable SDWR of $250 \mathrm{mg} / \mathrm{L}$ for drinking water.

A map of historical chloride concentrations in ground water in the four-county study area is shown in figure $14 A$. The map is based on results of analyses from 3,413 ground-water samples with historical concentrations ranging from 1.1 to $160,000 \mathrm{mg} / \mathrm{L}$ and a median chloride concentration of $67 \mathrm{mg} / \mathrm{L}$. Ninety-one percent of the samples contained chloride concentrations that were $500 \mathrm{mg} / \mathrm{L}$ or less.

In Butler County, historical chloride concentrations of $500 \mathrm{mg} / \mathrm{L}$ or greater may be associated with the extensive past or present oilfield activities in the county (fig. 15). In Cowley County, Bayne (1962, table 6 and p. 100) reported chloride concentrations in 215 ground-water samples ranging from 11 to $17,300 \mathrm{mg} / \mathrm{L}$, with the largest concentrations in a ground-water sample from terrace deposits adjacent to the Arkansas River and in association with a still active oilfield. Of the 215 samples, 87 (40 percent) contained chloride in excess of $250 \mathrm{mg} / \mathrm{L}$, all but one of which were collected from alluvium or terrace deposits in the Arkansas River Valley and adjacent areas (Bayne, 1962).

In Sedgwick County, Lane and Miller (1965a) reported chloride concentrations in 297 ground-water samples ranging from 4 to $1,695 \mathrm{mg} / \mathrm{L}$, and 24 years later, Bevans (1989) reported chloride concentrations in 101 ground-water samples ranging from 7.5 to $630 \mathrm{mg} / \mathrm{L}$. Ground-water contamination from oilfield brine was indicated in 16 of the samples from the study by Bevans (1989, p. 115).

In Sumner County, Walters (1961) reported chloride concentrations in 219 ground-water samples ranging from 60 to $160,000 \mathrm{mg} / \mathrm{L}$. Of these samples, 170 had chloride concentrations less than $500 \mathrm{mg} / \mathrm{L}, 20$ contained 500 to $2,000 \mathrm{mg} / \mathrm{L}$, 11 contained 2,001 to $10,000 \mathrm{mg} / \mathrm{L}$, and 18 contained more than $10,000 \mathrm{mg} / \mathrm{L}$. Walters (1961, p. 49) and Gogel (1981) thought that the large chloride concentrations west of Belle Plaine along the Ninnescah River were due to natural contamination upwelling from the Wellington Formation, whereas the large chloride concentrations in the Oxford area were due to contamination from oilfield brine (see also fig. 15). Figure $14 A$ shows historical chloride concentrations ranging from less than 250 to more than 2,000 mg/L in water from Sumner County wells.

The results of analyses for chloride in the August 2003 water-quality samples from 30 ground-water sites and 10 surface-water sites are shown in figure $14 B$ and listed in table 11 at the back of this report. Only one sample collected from the ground-water sites contained a chloride concentration that exceeded the SDWR, and seven surface-water samples had chloride concentrations that exceeded the SDWR. Chloride concentrations in the August 2003 ground-water samples ranged from 5.2 to $380 \mathrm{mg} / \mathrm{L}$ and do not appear to be of major concern in the areas sampled (fig. 14B). Chloride concentrations in the August 2003 surface-water samples ranged from
41 to $1,990 \mathrm{mg} / \mathrm{L}$ and were largest in surface-water samples from the downstream reach of Slate Creek (map number 35, fig. 14B) and the oxbow lake (map number 39). Chloride concentrations were smallest ( 41 and $46 \mathrm{mg} / \mathrm{L}$ ) in samples from the two sand quarries (map numbers 40 and 37, respectively, fig. 14B). The two sand-quarry chloride concentrations probably reflect the predominant ground-water contribution to the quarries.

\section{Sulfate}

Sulfur is widely distributed in reduced form in both igneous and sedimentary rock as metallic sulfides. When sulfide minerals undergo weathering in contact with aerated water, the sulfur is oxidized to yield sulfate ions that go into solution in water. Pyrite crystals occur in many sedimentary rocks and constitute a source of ferrous iron and sulfate in ground water. Oxidation of pyrite and other forms of sulfur also is promoted by humans through the combustion of fuels and the smelting of ores, which contribute sulfate to natural water. Sulfate also is a common constituent in seawater $(2,700 \mathrm{mg} / \mathrm{L})$ and brines $(\mathrm{Hem}$, 1992, p. 112-113).

Sulfate when combined with calcium or magnesium contributes most of the permanent hardness to natural water, and the removal of these constituents is both difficult and expensive. Sulfate in excessive amounts (more than $500 \mathrm{mg} / \mathrm{L}$ ) in water used for drinking or livestock watering is undesirable because of the laxative effect when the water is first used. A concentration of less than $250 \mathrm{mg} / \mathrm{L}$ is recommended for human consumption, although a concentration as great as $2,000 \mathrm{mg} / \mathrm{L}$ may be tolerated. Because of its potential laxative effect, the U.S. Environmental Protection Agency (2003) has recommended a nonenforceable SDWR of $250 \mathrm{mg} / \mathrm{L}$ in drinking water.

A map showing historical sulfate concentrations in water from wells in the four-county study area is shown in figure $16 \mathrm{~A}$. The map is based on results of analyses from 2,902 groundwater samples with historical concentrations ranging from 0.40 to $7,800 \mathrm{mg} / \mathrm{L}$ and a median sulfate concentration of $74 \mathrm{mg} / \mathrm{L}$. Seventy-two percent of the samples contained sulfate concentrations that were $250 \mathrm{mg} / \mathrm{L}$ or less.

Historical sulfate concentrations in water from wells in Butler County were generally larger in water from the unconsolidated deposits along the Whitewater River than in other areas of the county (fig. 16A). In Cowley County, Bayne (1962, p. 100) reported sulfate in 138 ground-water samples in concentrations ranging from 5.3 to $1,490 \mathrm{mg} / \mathrm{L} ; 11$ samples contained concentrations of more than $250 \mathrm{mg} / \mathrm{L}$. Figure $16 \mathrm{~A}$ shows historical sulfate concentrations that were generally $250 \mathrm{mg} / \mathrm{L}$ or less in water from Cowley County wells.

Lane and Miller (1965a, table 5) reported sulfate concentrations in 81 ground-water samples from Sedgwick County that ranged from 11 to $1,550 \mathrm{mg} / \mathrm{L}$, whereas Bevans (1989, table 15) reported sulfate concentrations in 101 ground-water samples that ranged from 15 to $1,700 \mathrm{mg} / \mathrm{L}$. Figure $16 \mathrm{~A}$ generally shows larger historical sulfate concentrations in water from 
upland wells in Sedgwick County than in wells located in the unconsolidated deposits adjacent to major streams.

In Sumner County, Walters (1961, p. 51) reported sulfate concentrations in 95 ground-water samples ranging from 3.7 to $7,800 \mathrm{mg} / \mathrm{L}$. Of these samples, 30 had sulfate concentrations less than $50 \mathrm{mg} / \mathrm{L}, 36$ contained 50 to $250 \mathrm{mg} / \mathrm{L}, 8$ contained 251 to $1,000 \mathrm{mg} / \mathrm{L}$, and 21 contained more than $1,000 \mathrm{mg} / \mathrm{L}$. Figure $16 \mathrm{~A}$ also shows generally larger historical sulfate concentrations in water from upland wells in Sumner County than in water from wells located adjacent to major streams.

The results of analyses for sulfate in the August 2003 water-quality samples from 30 ground-water sites and 10 surface-water sites are shown in figure $14 B$ and listed in table 11 at the back of this report. Only one water-quality sample collected from the modeled area contained a sulfate concentration that exceeded the SDWR. The surface-water sample from Slate Creek (map number 35, fig. 16B) had a sulfate concentration of $480 \mathrm{mg} / \mathrm{L}$. Sulfate concentrations in the August 2003 groundwater samples ranged from 16 to $210 \mathrm{mg} / \mathrm{L}$. Sulfate concentrations in the August 2003 surface-water samples ranged from 64 to $480 \mathrm{mg} / \mathrm{L}$ and were smallest $(64 \mathrm{mg} / \mathrm{L})$ in samples from the Ninnescah River near Peck (map number 33, fig. 16B) and in the sand quarry near Oxford (map number 37). Overall, sulfate concentrations in the water-quality samples collected during August 2003 do not exceed standards.

\section{Alluvial Aquifer Characteristics in Modeled Area}

Although ground water is found in the subsurface throughout the study area, the hydrogeologic properties of the rock and unconsolidated subsurface deposits determine the availability of water. Most of the bedrock consists of fine-grained shale, silty shale, and siltstone, with some instances of limestone. The fine-grained consolidated nature of the shale and siltstone hinders the movement of water and limits recharge and yields to wells. In areas where the consolidated limestone has weathered or developed solution openings, yields of generally hard water may range from less than 10 to as much as $350 \mathrm{gal} / \mathrm{min}$ in localized areas (Lane and Miller, 1965a; Bevans, 1989).

In general, saturated unconsolidated deposits yield much larger quantities of water to wells than saturated bedrock in the study area. The saturated unconsolidated deposits in the Arkansas River Valley can yield as much as $2,000 \mathrm{gal} / \mathrm{min}$ (Bevans, 1989) and from 50 to about $300 \mathrm{gal} / \mathrm{min}$ in the Ninnescah River Valley where they are thinner and generally less permeable (Lane and Miller, 1965a). The saturated portion of the post-Illinoisan unconsolidated deposits shown in figure 9 is referred to as the "alluvial aquifer" in this report and will be the only aquifer discussed in the rest of this report.

\section{Areal Extent and Hydraulic Properties}

The Arkansas River alluvial aquifer extends laterally between the alluvial valley walls where bedrock crops out (fig. 9) and vertically from the land surface to the top of the bedrock. A map showing the configuration of the bedrock in the modeled area is shown in figure 17. This map is based on information from driller's logs on file with the Kansas Geological Survey (KGS) (well driller's log WWWC-5 database, Lawrence, Kansas) and published well logs, maps, and (or) geologic sections found in Walters (1961), Bayne (1962), Lane and Miller (1965a,b), and Gogel (1981). The altitude of the bedrock surface ranges from a low of about $1,050 \mathrm{ft}$ in Cowley County to a high of greater than 1,300 ft in Sedgwick County (fig. 17).

Hydraulic properties of an aquifer provide important information in the evaluation of ground-water problems by giving an indication of well yield in a particular aquifer and by providing the necessary data for ground-water modeling. Hydraulic properties include estimates of hydraulic conductivity, transmissivity, storage coefficient, and specific yield. Under unconfined conditions, as is the case in the alluvial aquifer in the modeled area, the storage coefficient and the specific yield are virtually equal.

A general review of lithologic logs of wells in the modeled area does not indicate the presence of widespread or laterally extensive confining units (such as clay and shale) within the unconfined alluvial aquifer. This absence of widespread confining units and the generally sand-and-gravel nature of the alluvial sediment result in relatively uniform hydraulic conductivity from top to bottom in the aquifer. In the northern part of the modeled area, Myers and others (1996), using aquifer-test data (Reed and Burnett (1985), pumping tests, and lithologic logs from eight observation wells southeast of Maize (Maize section, plate 2), estimated hydraulic conductivity in the upper unit of the Equus Beds aquifer (alluvial deposits that ranged from 2 to about $110 \mathrm{ft}$ below land surface). Myers' estimates for hydraulic conductivity ranged from 50 to $750 \mathrm{ft} / \mathrm{d}$, with $750 \mathrm{ft} / \mathrm{d}$ most common in the alluvial deposits near the Arkansas River (Myers and others, 1996, fig. 21A). Near the southern end of the modeled area, Spruill (1993, p. 10-11), using information from Lohman (1979, table 17) and lithologic information from selected wells and test holes, estimated hydraulic conductivity of the alluvial aquifer at an abandoned oil refinery located just southeast of the modeled area on the western edge of Arkansas City. Spruill's estimates ranged from about $15 \mathrm{ft} / \mathrm{d}$ for fine sand found in the upper part of the aquifer to about $800 \mathrm{ft} / \mathrm{d}$ for coarse sand and gravel found in the lower 5 to $10 \mathrm{ft}$ of the alluvial aquifer. Average hydraulic-conductivity values from eight wells at the abandoned refinery ranged from 25 to about $375 \mathrm{ft} / \mathrm{d}$ (Spruill, 1993, table 1).

Specific capacities, computed from drillers' logs, varied widely in the modeled area and were not considered reliable estimates of hydraulic conductivity or aquifer transmissivity. Hansen (1985, p. 13, plate 3) estimated specific yield of the alluvial aquifer in the modeled area at 0.15 on the basis of values reported in Fader and Morton (1975). 


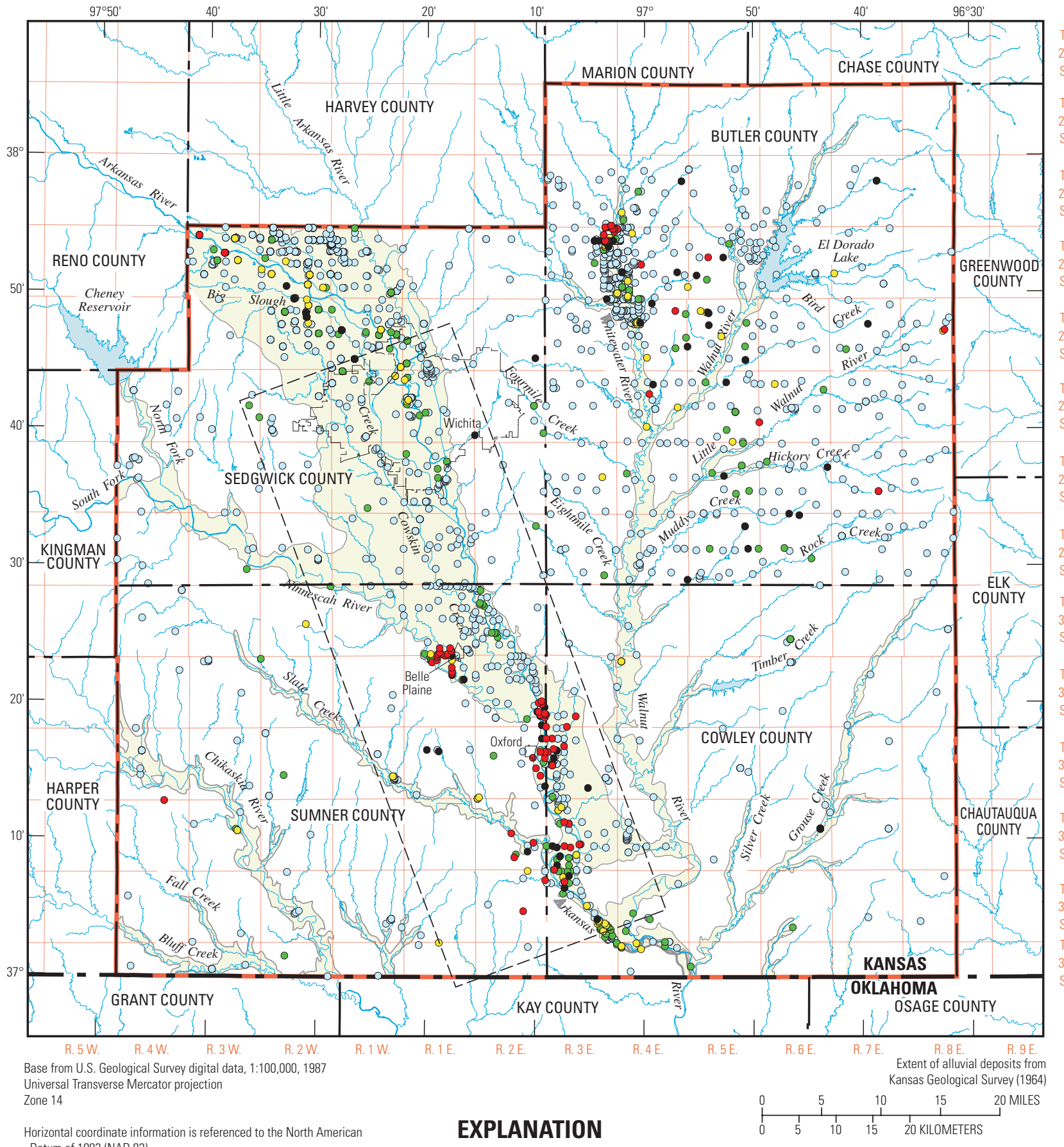
Datum of 1983 (NAD 83)

Chloride concentration, in
milligrams per liter
$\circ 0-250 \quad$ • $861-2,000$
$\circ 251-500 \quad \bullet$ Greater than 2,000
$\circ 501-860 \quad \circ$ Not determined

Alluvial deposits

- - - Boundary of modeled area

Boundary of four-county study area

Figure 14. (A) Historical chloride concentrations in water from wells in the four-county study area (data from U.S. Geological Survey OWDATA database). 


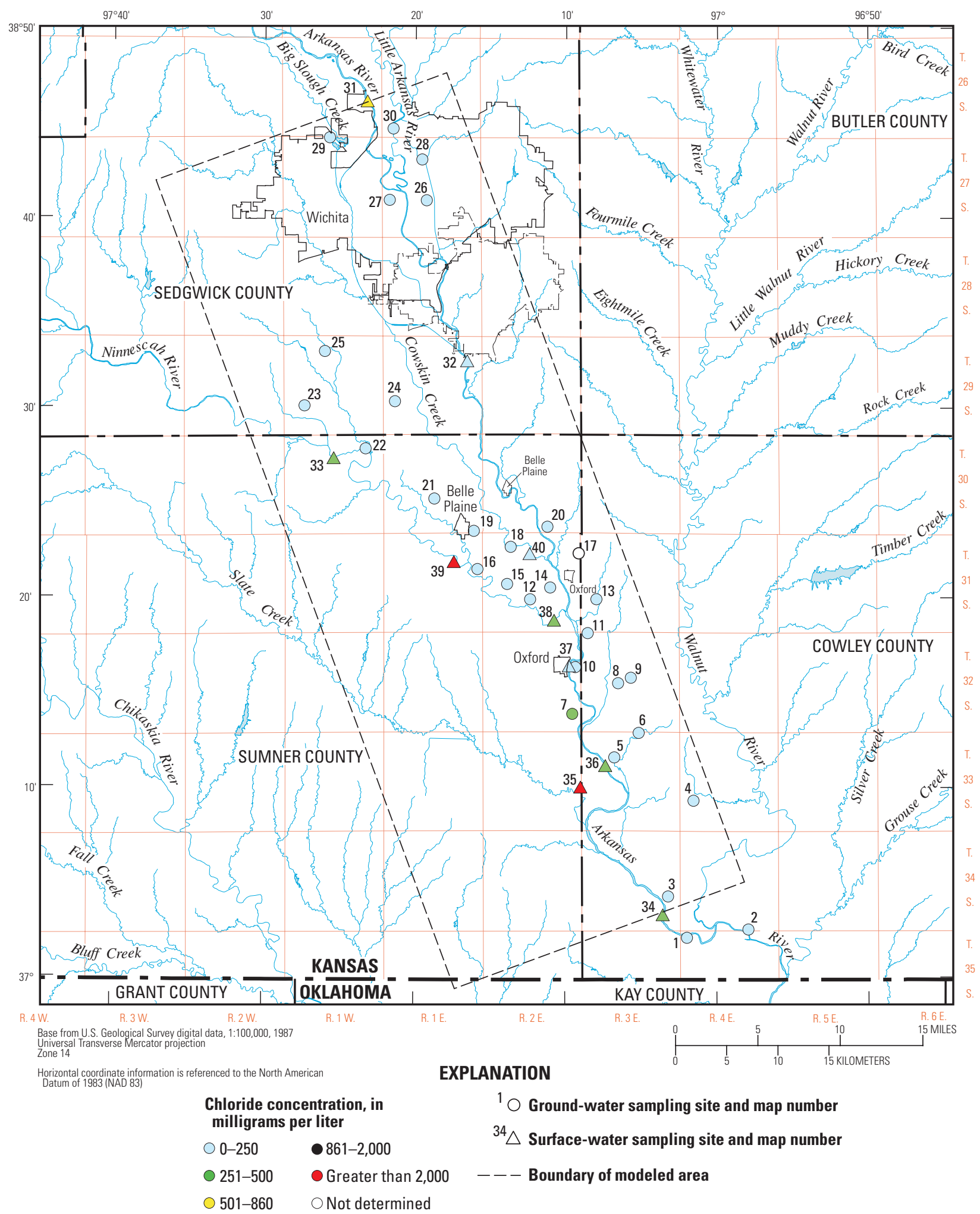

Figure 14. (B) Chloride concentrations in ground- and surface-water samples collected from modeled area, August 2003. 


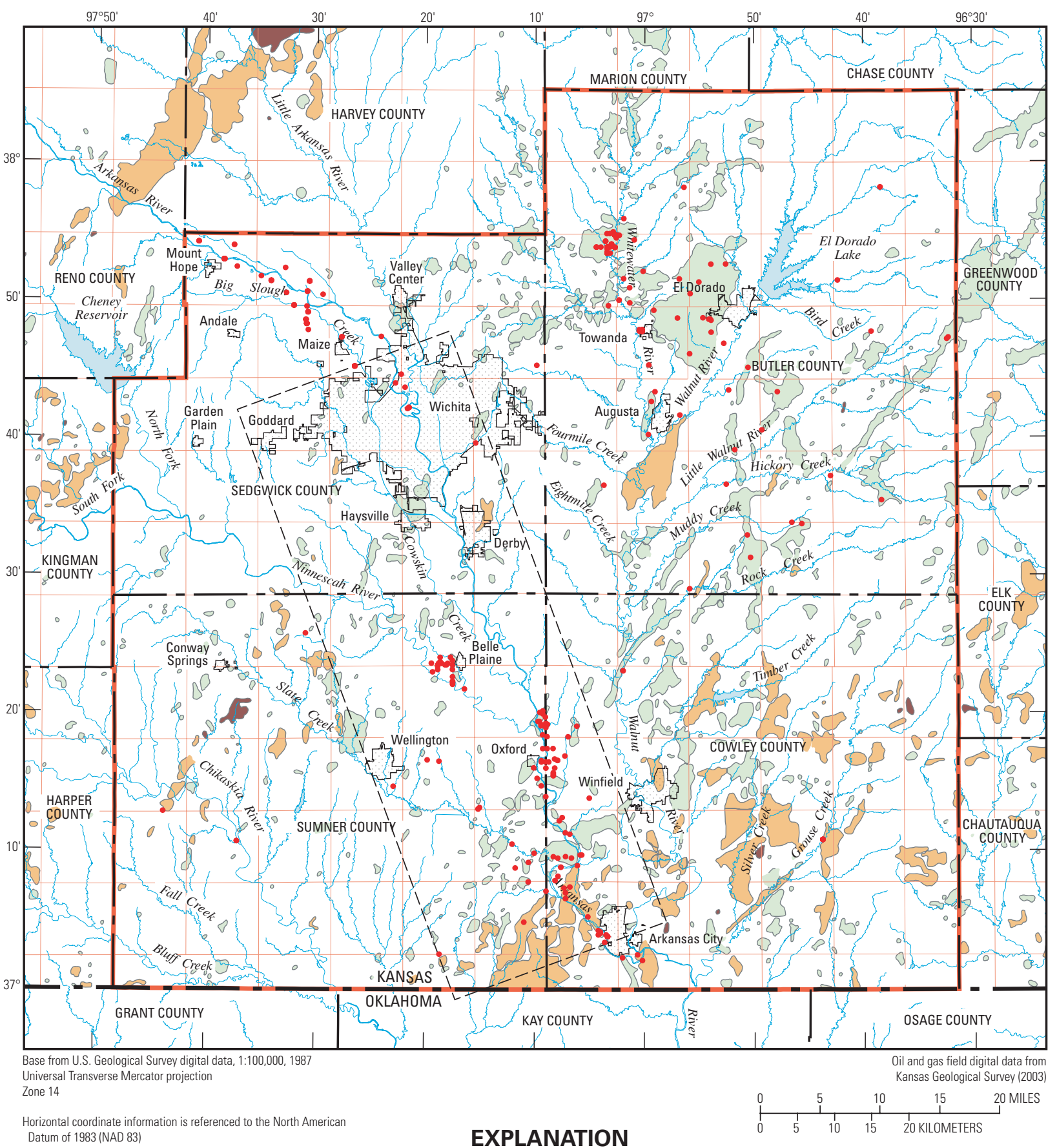

Oilfield

Boundary of modeled area

Oil and gas field

Boundary of four-county study area

Gas field

- Well with chloride concentration equal to or greater than $\mathbf{5 0 0}$ milligrams per liter

Figure 15. Location of past and present (2003) oil and gas fields in the four-county study area (from Kansas Geological Survey, 2003) and wells with chloride concentrations in water samples equal to or greater than 500 milligrams per liter. 


\section{Water Levels and Direction of Flow}

An inventory of existing water wells in the four-county study area was done to identify potential ground-water-level measurement data-collection sites. Seventy-five wells from either the USGS National Water Information System groundwater (GWSI) or the KGS WWWC-5 database were selected using a 2- by 3-mi grid overlain on a map of the extent of the alluvial deposits in the lower Arkansas River Basin (Kansas Geological Survey, 1964) in the modeled area. The wells were selected to give the widest, most evenly distributed picture of ground-water conditions in the alluvial aquifer as possible. Water levels in the 75 wells were measured twice, in March 2001 and February 2002. Water levels were measured to the nearest $0.01 \mathrm{ft}$ using an electric tape. The ground-water-level data were used to draw maps of the altitude of the water-level surface and direction of ground-water flow in the alluvial aquifer at specific points in time (fig. 18A and 18B). Some of the measured wells were not used in the water-level maps because they were located outside of the modeled area and are not included in the data compilation in table 12. The ground-waterlevel data also provided a set of water levels to establish initial conditions as well as calibration target for the numerical model. The location, depth to water, land-surface altitude, groundwater altitude, and supporting information (water use and depth of well) for the 68 wells used in water-level-map compilation are given in table 12 in the "Supplemental Information" section at the back of this report. In March 2001 and February 2002, water-level altitudes in the alluvial aquifer in the modeled area ranged from about 1,090 ft in southeastern Cowley County to about 1,340 ft in Sedgwick County north of Wichita (fig. 18, table 12).

Depths to water in wells measured in March 2001 ranged from about $3.0 \mathrm{ft}$ below land surface in a lawn and garden well north of Wichita to about $45 \mathrm{ft}$ below land surface in an irrigation well southwest of Wichita. Depths to water in wells measured in February 2002 ranged from about $6.6 \mathrm{ft}$ below land surface in a domestic well in Sumner County south of Derby to about $46 \mathrm{ft}$ below land surface in an irrigation well southwest of Wichita (table 12). In all but two wells, water levels measured in February 2002 were lower than those measured in March 2001; they were lower an average of $2.38 \mathrm{ft}$. Streamflow in the Arkansas River at Derby was well below the long-term median $\left(526 \mathrm{ft}^{3} / \mathrm{s}\right.$, table 1$)$ in February $2002\left(255 \mathrm{ft}^{3} / \mathrm{s}\right)$ and above the median in March $2001\left(938 \mathrm{ft}^{3} / \mathrm{s}\right.$ ) (table 13 in the "Supplemental Information" section at the back of the report). Larger streamflows occur at higher stream stages.

Long-term historical water levels in the study area are available for only a few wells. An example is observation well 26S-02W-29AAA01 northwest of Wichita where water levels have been measured periodically. Water levels since 1962 in this well are plotted in figure 19. In general, ground-water levels in and adjacent to the modeled area are strongly affected by precipitation and, if near a perennial stream, by the stream. Water levels fluctuate seasonally. Historic measurements show that water levels in this part of the alluvial aquifer have remained relatively stable since the 1960s, indicating a system in relative balance and near steady-state conditions (fig. 19).

Unconfined ground water flows from higher to lower altitudes in the direction that is perpendicular (in isotropic aquifers) to the water-level contours (fig. 18). In the modeled area, the direction of ground-water flow in March 2001 and February 2002 is primarily down the valley parallel to the Arkansas River and toward the major streams.

\section{Saturated Thickness}

Saturated thickness of the alluvial aquifer in the modeled area is the difference between the water-level altitude (figs. $18 \mathrm{~A}$ and $18 B$ ) and the bedrock-surface altitude (fig. 17) and in the modeled area ranged from less than $25 \mathrm{ft}$ along the aquifer boundary and in some of the southern parts of the area to almost $150 \mathrm{ft}$ in the thickest part of the aquifer in the northwestern part of the modeled area (figs. $20 \mathrm{~A}$ and $20 \mathrm{~B}$ ) and averaged $38 \mathrm{ft}$ for March 2001 and February 2002. Hansen (1985, plate 1) mapped estimated saturated thickness of the alluvial aquifer statewide. Hansen's estimates of saturated thickness in the study area ranged from less than $40 \mathrm{ft}$ in most of Butler, Cowley, and Sumner Counties to more than $120 \mathrm{ft}$ in north-central Sedgwick County (Hansen, 1985, plate 1). The width of the river valley in the modeled area generally ranges from 5 to $10 \mathrm{mi}$.

\section{Surface-Water and Ground-Water Interaction}

A hydrograph of a stream gage (Little Arkansas River at Valley Center) and a nearby well in the northern part of the study area show a good hydraulic connection between the river and the alluvial aquifer (fig. 21). Water-level changes in the river are transmitted rapidly to the aquifer and nearby well. Hydrographs at a nest of wells at different depths near a stream gage on the Arkansas River northwest of the study area near Hutchinson (fig. 22) indicate a similar good connection between the river and all depths in the aquifer (Myers and others, 1996). Given that the source of alluvial aquifer material is similar for these two areas as it is for the study area and the minimal aquifer thickness in the modeled area (average of $38 \mathrm{ft}$ ), it is likely that the connection between the Arkansas River and the entire alluvial aquifer thickness is very good in the modeled area.

The relation of the water-level altitude in the alluvial aquifer to the Arkansas River is indicative of the hydraulic conductivity of the unconsolidated deposits near the river. Water-level contours cross the Arkansas River nearly perpendicular to the channel (fig. 18). River stage and ground-water levels are very nearly the same because nearby aquifer sediment consists of coarse sand and gravel that transmit water-level changes rapidly (Myers and others, 1996). 


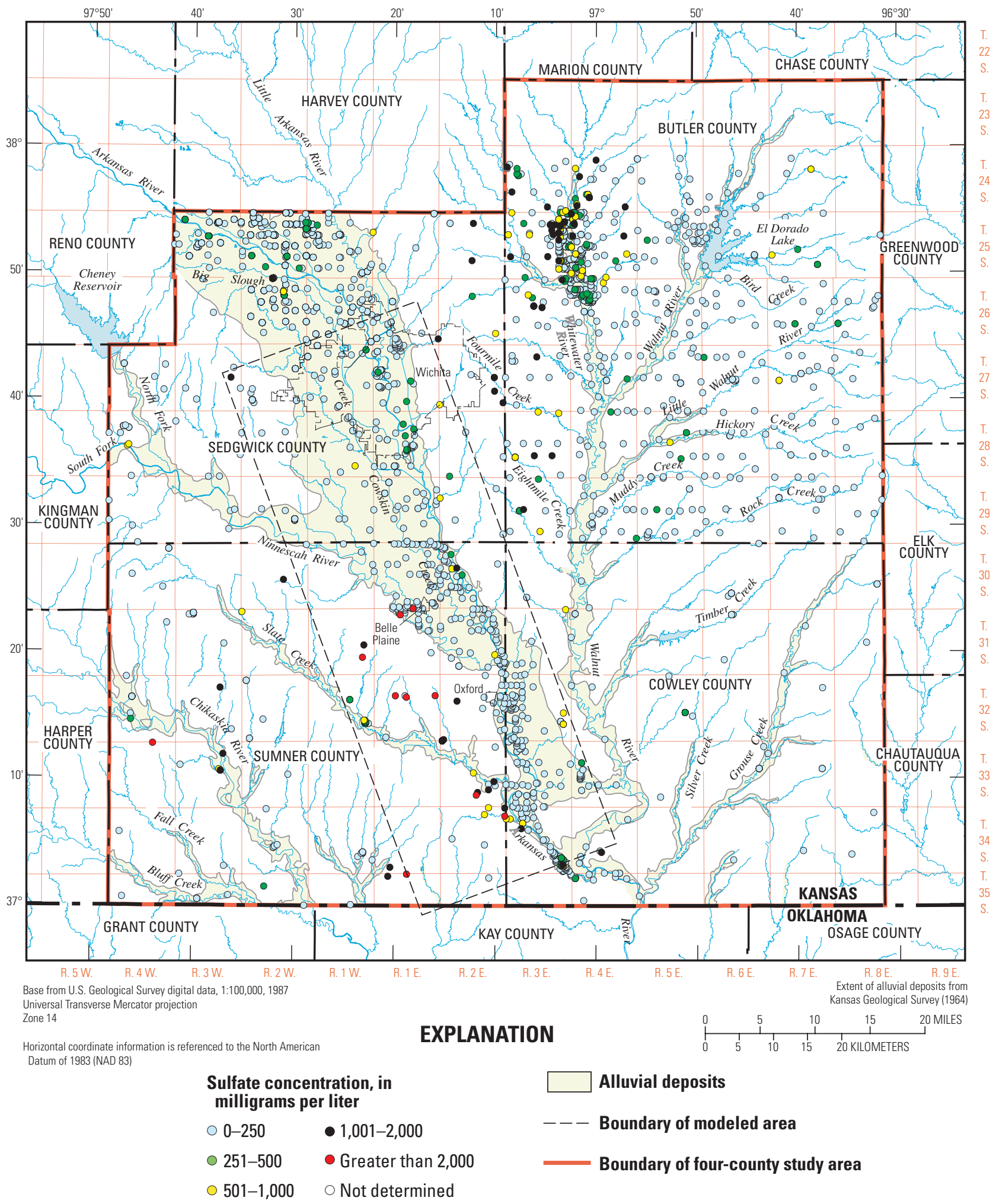

Figure 16. (A) Historical sulfate concentrations in water from wells in the four-county study area (data from U.S. Geological Survey OWDATA database). 


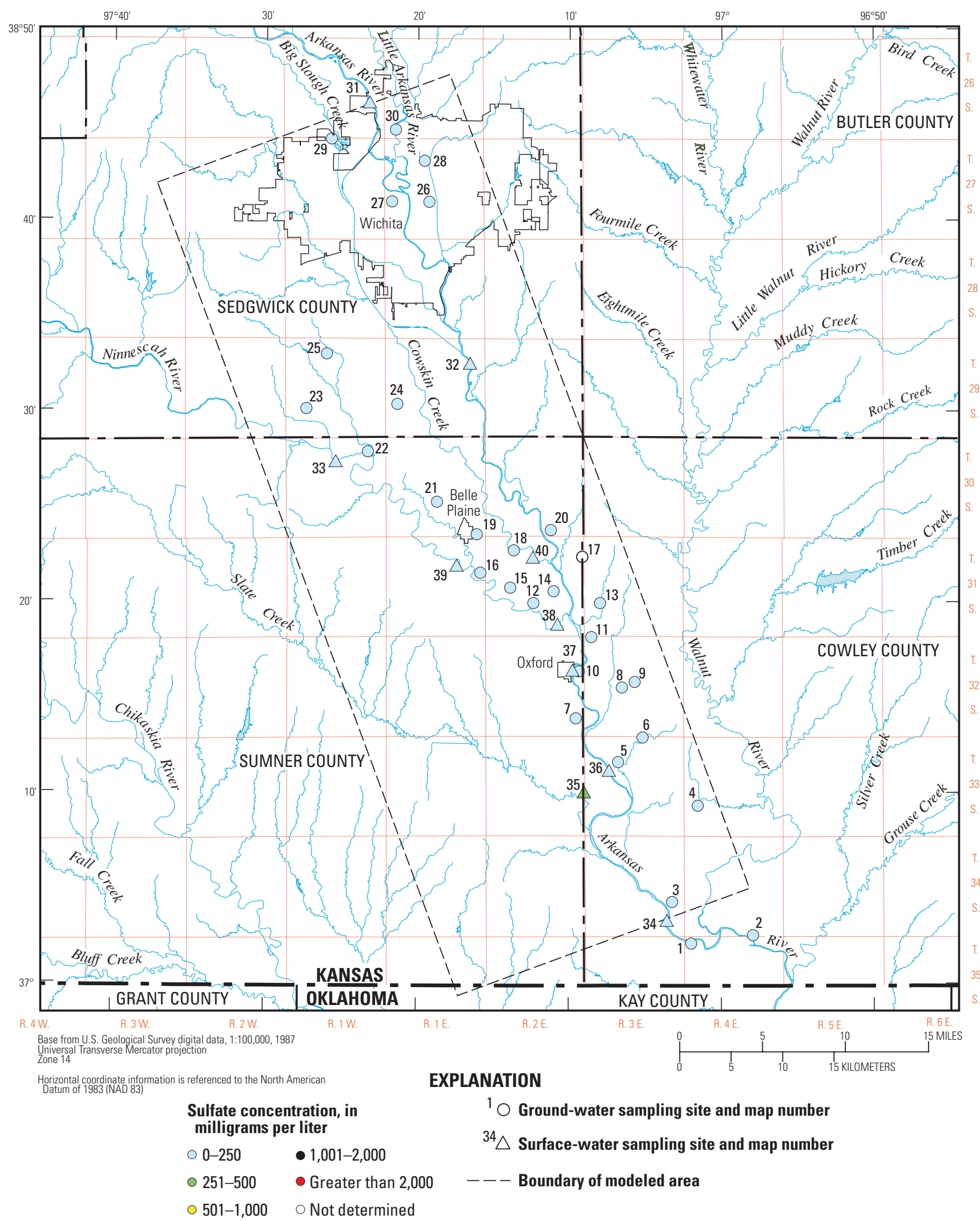

Figure 16. (B) Sulfate concentrations in ground- and surface-water samples collected from modeled area, August 2003. 


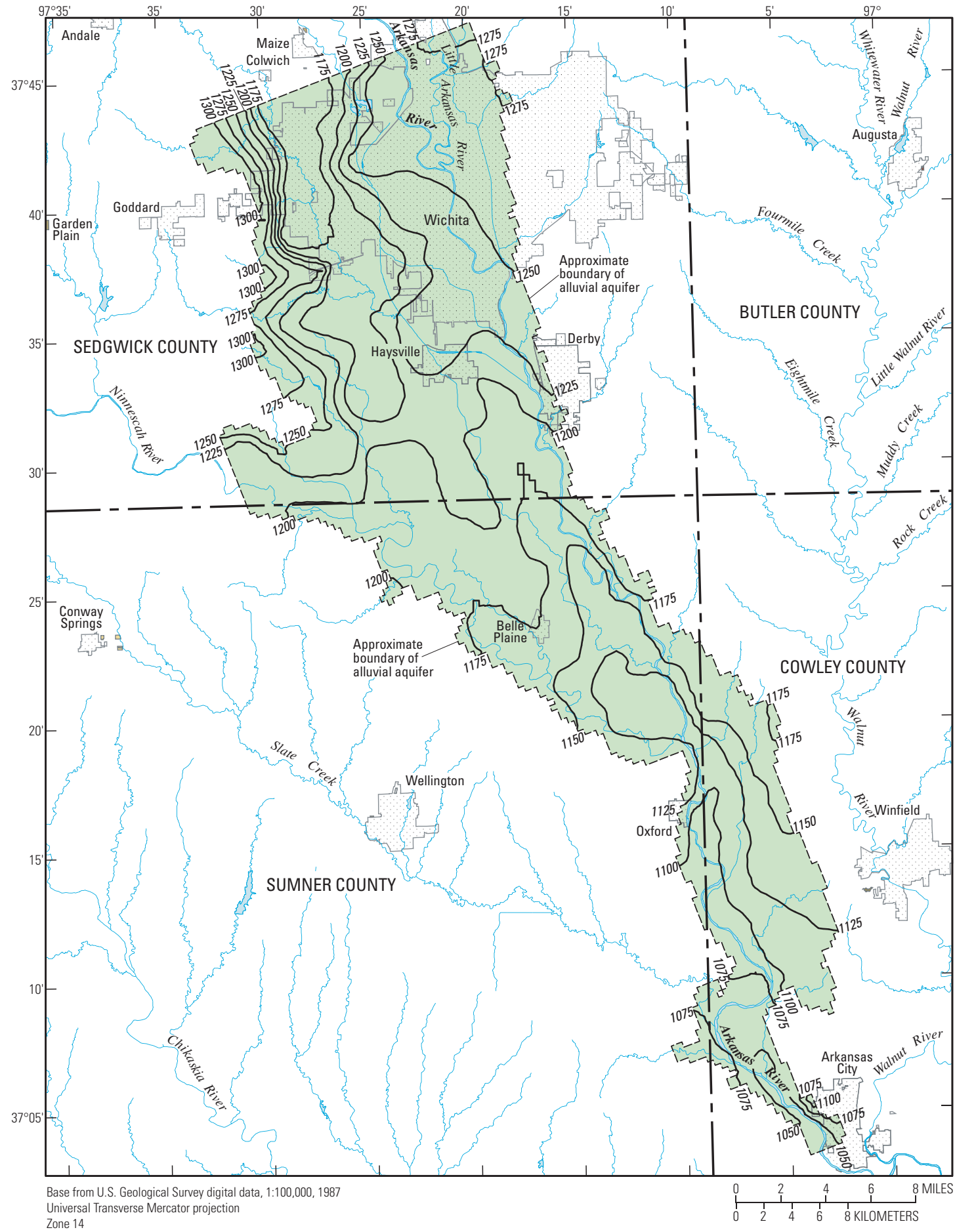

Horizontal coordinate information is referenced to the North American Datum of 1983 (NAD 83)

\section{EXPLANATION}

Approximate extent of alluvial deposits in modeled area

- 1075- Bedrock contour-Shows altitude of bedrock surface. Contour interval 25 feet. Datum is North American Vertical Datum of 1988

Figure 17. Configuration of bedrock surface in modeled area. Geology based on driller's logs on file with the Kansas Geological Survey (WWWC-5 database, Lawrence, Kansas) and published well logs, maps, and (or) geologic sections found in Walters (1961), Bayne (1962), Lane and Miller (1965a,b), and Gogel (1981). 


\section{Conceptual Model of the Alluvial Aquifer}

A conceptual model of the alluvial aquifer, including boundaries and ground-water recharge and discharge, is useful to aid in understanding the ground-water flow system, in formulating the ground-water flow model, and for evaluation of results from the model.

\section{Boundaries}

Within the modeled area (fig. 9), the upper shale member of the Wellington Formation forms a low-permeability barrier to ground-water flow. This shale member occurs beneath the alluvial aquifer where it exists throughout all of the modeled area. The alluvial aquifer extends generally east and west to the valley-wall interface between the alluvial deposits and the Wellington Formation. The unconsolidated deposits that comprise the alluvial aquifer extend north and south beyond the modeled area along the Arkansas River in Sedgwick and Cowley Counties, west along the Ninnescah River in Sedgwick County and along Slate Creek in Sumner County, and north along the Walnut River in Butler and Cowley Counties.

\section{Water-Budget Components}

Inflow to the alluvial aquifer in the modeled area is from recharge, ground-water inflow from adjacent areas, and seepage from the Arkansas and Ninnescah Rivers to the aquifer. Major components of outflow from the alluvial aquifer in the modeled area consist of ground-water flow out of the valley, seepage from the alluvial aquifer to the Arkansas and Ninnescah Rivers, and ground-water pumpage.

\section{Recharge}

The quantity of recharge from precipitation in any area is a function of the quantity and intensity of precipitation, types of vegetation, topography, soil permeability and antecedent soil moisture, and aquifer characteristics (permeability, porosity, depth to water, and capacity to store the recharge) (Bevans, 1989, p. 80). The Arkansas River Valley in the modeled area is readily recharged by precipitation. The valley receives moderate precipitation (about $32.5 \mathrm{in} / \mathrm{yr}$, average of 1961-90 mean annual precipitation at Arkansas City and Wichita), and land cover is primarily grassland and cropland. The valley is relatively flat, which allows for less runoff and more infiltration through the highly permeable sandy soil. The underlying alluvial deposits provide excellent aquifer storage as characterized by the thick deposits of unconsolidated sand and gravel especially in the northern part of the modeled area.

Recharge from precipitation occurs over all of the model area except where shale crops out (Sumner and Chase Groups, fig. 9). The amount of water reaching the saturated zone of the aquifer over the long term would be the total amount of precipitation minus the sum of surface runoff and evapotranspiration from the unsaturated zone, assuming no net change in subsurface storage. Results of previous investigations (Williams and Lohman, 1949; Stramel, 1956; Sophocleous, 1983; Dugan and Peckenpaugh, 1985; Sophocleous and Perry, 1985; Spinazola and others, 1985; Hansen, 1991; Myers and others, 1996) indicate that annual recharge in the Arkansas River Valley in the vicinity of the study area ranges from 0.44 to $8.80 \mathrm{in}$. (about 1.4 to 27 percent of the 1961-90 mean annual precipitation for the modeled area). The median value of this range is $4.6 \mathrm{in} / \mathrm{yr}$, which applied over the entire $430-\mathrm{mi}^{2}$ modeled area would yield $146 \mathrm{ft}^{3} / \mathrm{s}$.

\section{Lateral Ground-Water Inflow and Outflow}

Given the small permeability beneath and along the valleywall sides of the alluvial aquifer, it is assumed that relatively little or no flow into or out of the alluvial aquifer occurs there. Lateral ground-water inflow and outflow to the alluvial aquifer in the modeled area can occur from the alluvial aquifer outside the modeled area across a broad area along the northwestern boundary, across a small area along the Arkansas River on the southern boundary, and across two small areas on the western side where alluvial deposits along the Ninnescah River and Slate Creek enter the modeled area.

Estimated inflow across the northwestern boundary is about $51 \mathrm{ft}^{3} / \mathrm{s}$, assuming a hydraulic gradient of 0.001 (an average value throughout much of the modeled area, fig. 18A,B), a hydraulic conductivity of $750 \mathrm{ft} / \mathrm{d}$, and an inflow area of $5,911,000 \mathrm{ft}^{2}$. Estimated inflow on the western side of the modeled area along the Ninnescah River is about $7 \mathrm{ft}^{3} / \mathrm{s}$, assuming a hydraulic gradient of 0.001 , a hydraulic conductivity of $750 \mathrm{ft} / \mathrm{d}$, and an inflow area of 769,000 $\mathrm{ft}^{2}$. Estimated outflow on the southern side of the modeled area along the Arkansas River is about $2 \mathrm{ft}^{3} / \mathrm{s}$, assuming a hydraulic gradient of 0.001 , a hydraulic conductivity of $750 \mathrm{ft} / \mathrm{d}$, and an outflow area of $216,000 \mathrm{ft}^{2}$. Total estimated net subsurface inflow is $56 \mathrm{ft}^{3} / \mathrm{s}$.

\section{Flow From or To Streams}

Inflow to the alluvial aquifer as seepage from streams or outflow from the alluvial aquifer to streams occurs along the Arkansas River, Cowskin Creek, and the Ninnescah River in the modeled area. Net streamflow gain can be estimated using hydrograph separation techniques (Rutledge, 1998; 2000). Using these techniques for the period 1940-2001, base flows were computed for USGS stream gages in the study area. The period 1940-2001 was used because it was the longest common period of record of reasonably average hydrologic conditions for the major streamflow gages that excluded the exceptional drought period of the 1930s. Median flows also were computed for that time period. Streamflow gain was estimated for the Arkansas River between Wichita and Arkansas City by subtracting the base flow at upstream USGS stream gages 


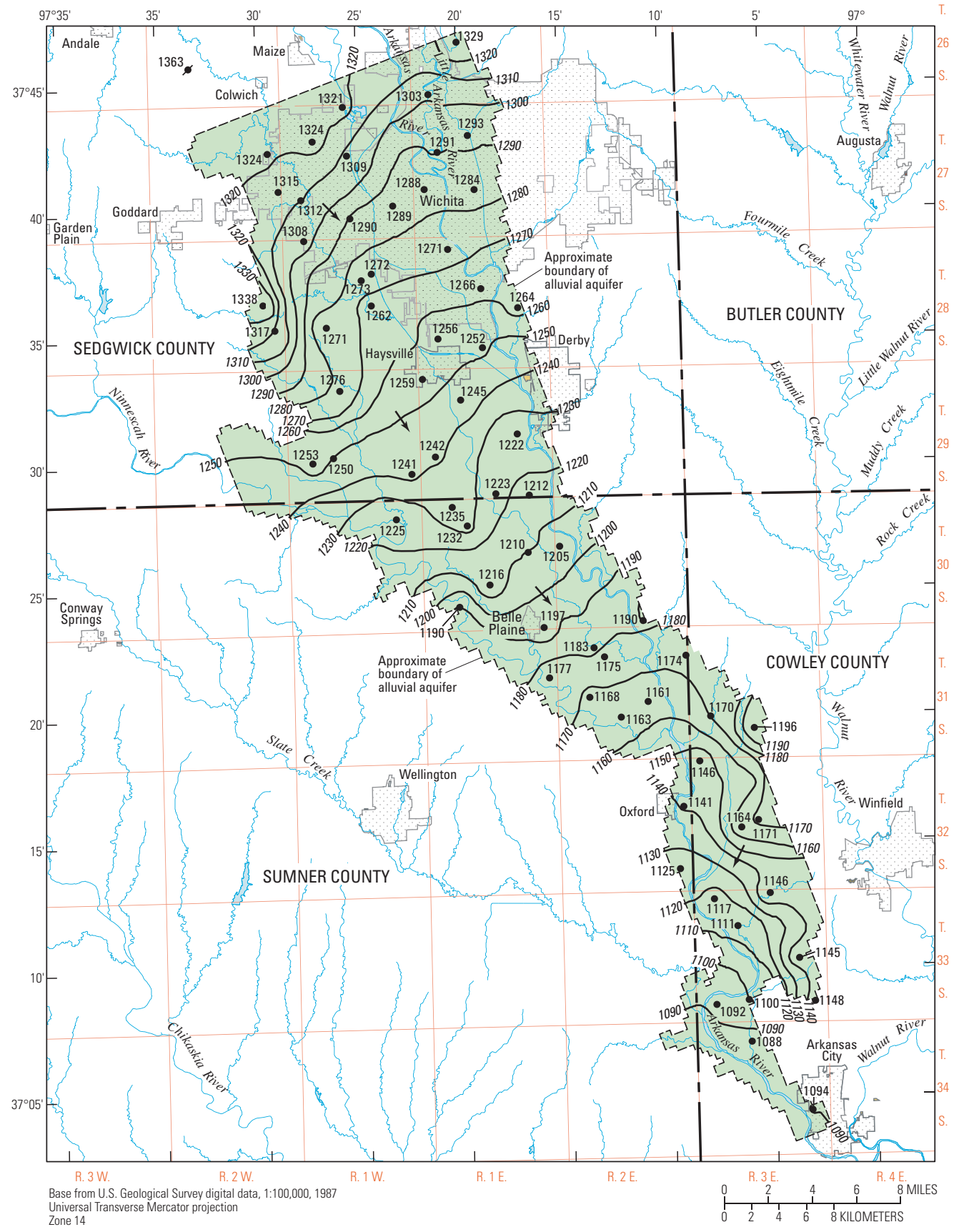

Zone 14

Horizontal coordinate information is referenced to the North American Datum of 1983 (NAD 83)

EXPLANATION

Approximate extent of alluvial deposits in modeled area

— 1070 - Water-table contour-Shows altitude of water table, March 2001. Contour interval 10 feet. Datum is North American Vertical Datum of 1988

$\longrightarrow$ Approximate direction of ground-water flow
1092 Ground-water sampling site-Number is altitude of water table, in feet, March 2001. Datum is North American Vertical Datum of 1988

1363 Observation well with long-term water-level measurements-Shown in figure 19. Number is altitude of water table, in feet, March 2001. Datum is North American Vertical Datum of 1988

Figure 18. (A) Water-level altitudes and approximate direction of ground-water flow in alluvial aquifer in modeled area, March 2001. 


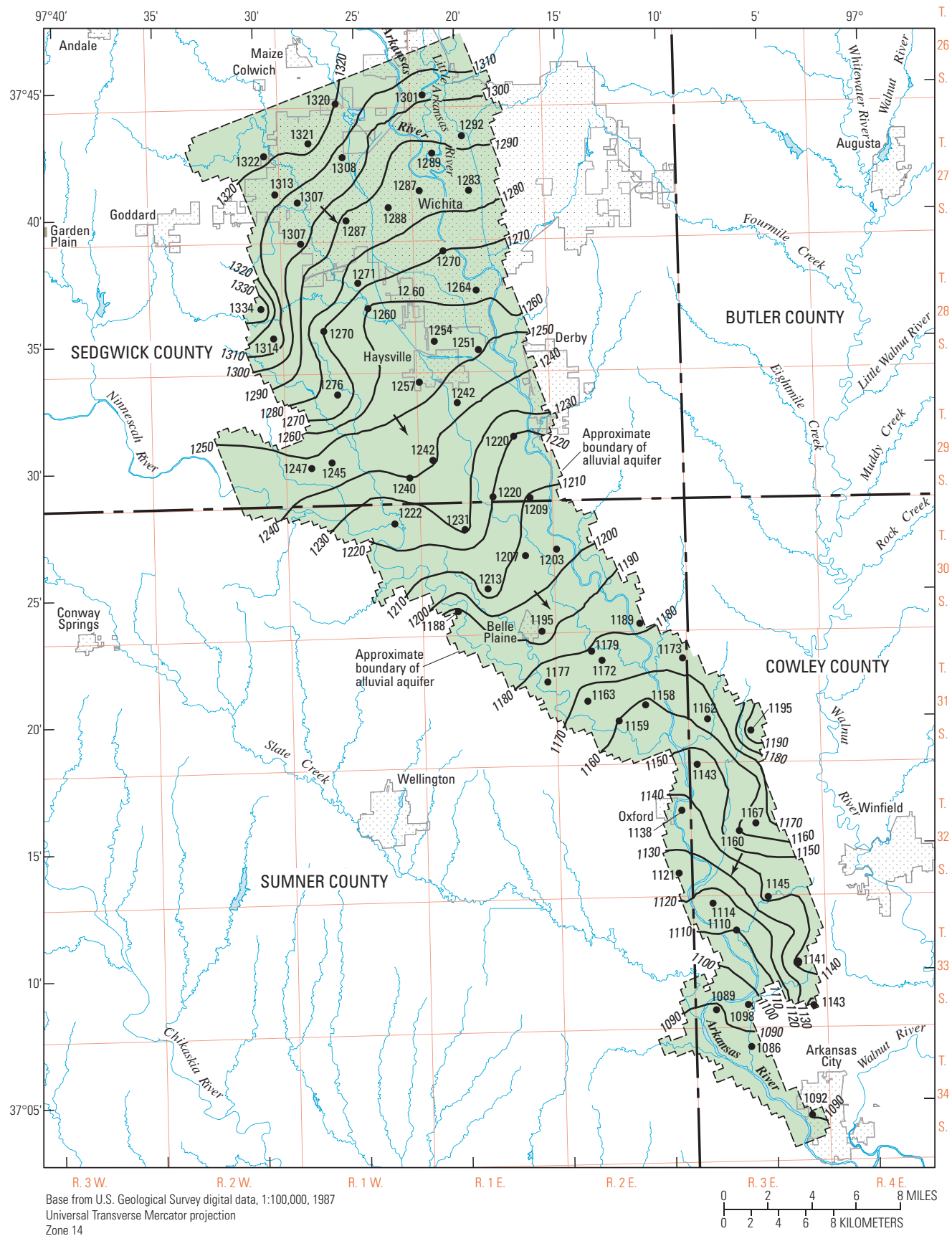

Zone 14

Horizontal coordinate information is referenced to the North American Datum of 1983 (NAD 83)

\section{EXPLANATION}

Approximate extent of alluvial deposits in modeled area

- 1070 - Water-table contour-Shows altitude of water table, February 2002. Contour interval 10 feet. Datum is North American Vertical Datum of 1988 $\longrightarrow$ Approximate direction of ground-water flow

1092 Ground-water sampling site-Number is altitude of water table, in feet, February 2002. Datum is North American Vertical Datum of 1988

Figure 18. (B) Water-level altitudes and approximate direction of ground-water flow in alluvial aquifer in modeled area, February 2002. 
(A) Observation well 26S-02W-29AAA 01

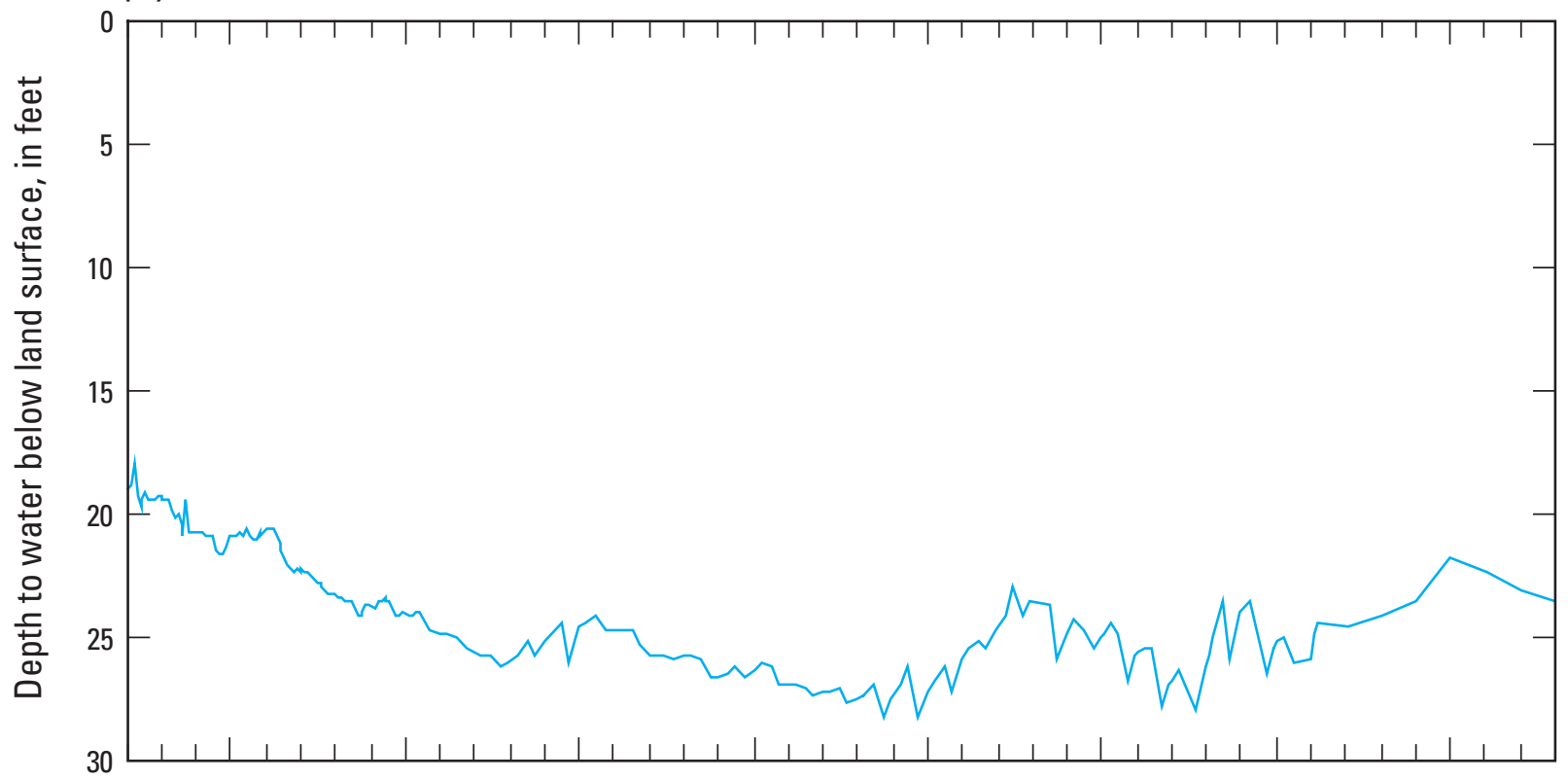

(B) Annual precipitation at Wichita

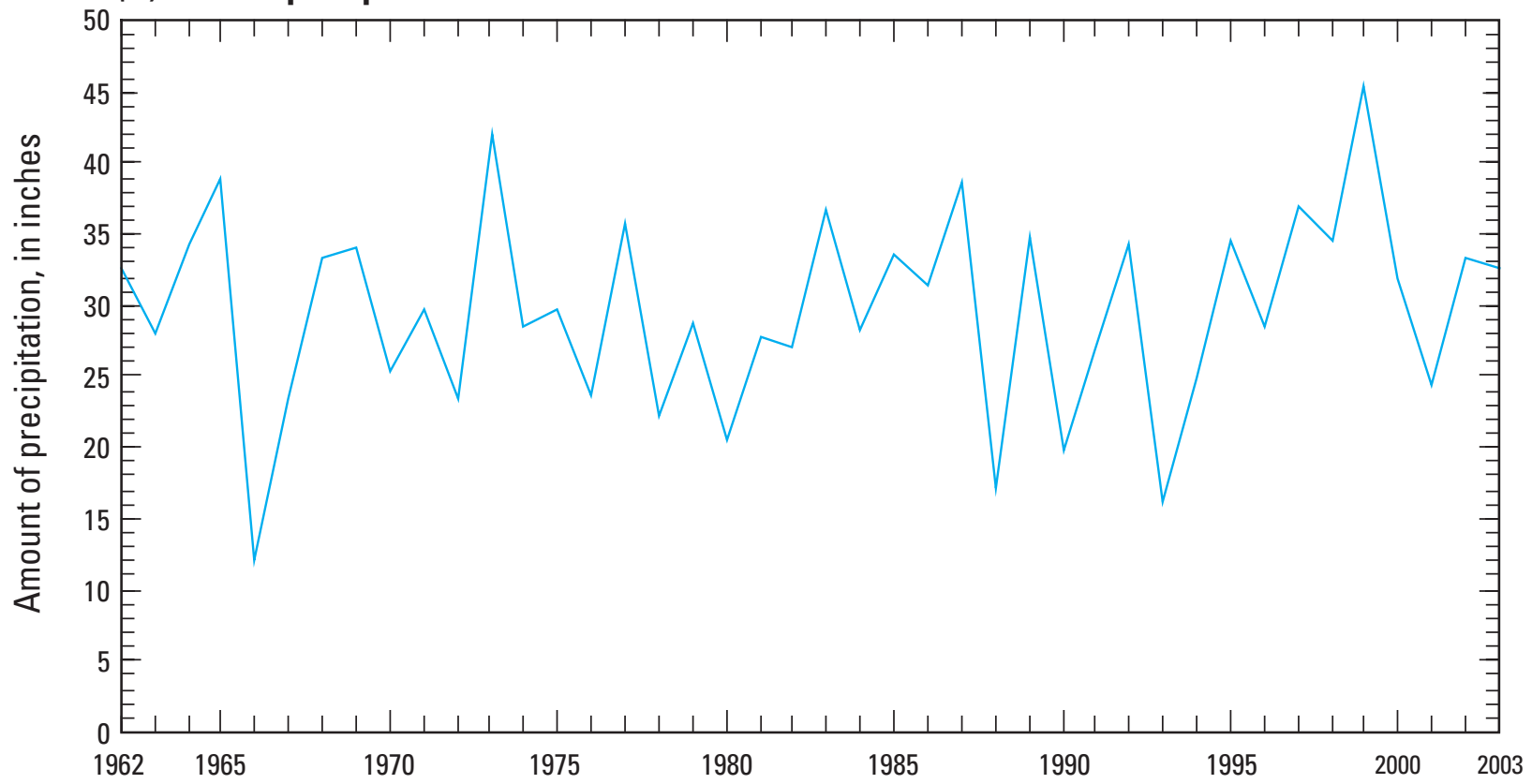

Figure 19. $(A)$ Ground-water levels in representative observation well in study area and $(B)$ annual precipitation at nearby Wichita, 1962-2003. Location of observation well shown in figure 18. Ground-water levels from U.S. Geological Survey National Water Information System and measurements made during this study. Precipitation data from High Plains Regional Climate Center (2003).

(Arkansas River at Wichita, station 07144300; Ninnescah River near Peck, station 07145500; Slate Creek at Wellington, station 07145700; and Cowskin Creek at 119 Street at Wichita, station 07144480), estimates of tributary flow derived from Perry and others (2004) using 50-percent duration flows, and average flow from the Wichita wastewater treatment plant north of Derby for the period 1986-2003 (Willie Whitaker, Wichita Wastewater Treatment Plant, written commun., 2003) from the base flow at the downstream stream gage (Arkansas River at
Arkansas City, station 07146500). The base flows were computed using the RORA program (Rutledge, 2000). The results are noted in table 6 . The more-recent base-flow computation (1970-2001) exceeded that of the longer term record computation (1940-2001) (171 compared to $\left.157 \mathrm{ft}^{3} / \mathrm{s}\right)$ despite greater average ground-water pumpage and Wichita treatment plant discharges during 1970-2001, both of which would reduce the amount of streamflow gain. Thus, the computed streamflowgain differences for these two relatively normal climatic periods 
exceed the human-induced changes during those periods. As a result, the 1940-2001 computation, that with the longer hydrologic record, was selected as most representative of streamflow gain $\left(157 \mathrm{ft}^{3} / \mathrm{s}\right)$.

Rutledge (2000) observed that base-flow separation techniques are more reliable on small and medium-sized streams than on larger streams like the Arkansas River. These techniques tend to overestimate base flow for large rivers because of poor streamflow recession characteristics of rivers with larger drainage basins.

Streamflow gain varies considerably with time. Figure 23 is a duration curve constructed by computing the streamflow difference on a daily basis (1-day lag) for the Arkansas River between Wichita and Arkansas City as indicated in the previous paragraph for the 1940-2001 period and rank ordering those daily streamflow gains. During drier times, this curve represents base flow; however, during wetter times, it is runoff dominated.

\section{Ground-Water Pumpage}

Outflow from the aquifer by ground-water pumpage from wells occurs throughout the modeled area. Municipal and industrial ground-water pumpage occurs in localized areas, whereas irrigation pumpage is more distributed over the modeled area. Average total ground-water pumpage for 1998-2001 in the modeled area was reported to be about $36 \mathrm{Mgal} / \mathrm{d}$ $\left(56 \mathrm{ft}^{3} / \mathrm{s}\right)$ (table 5 ).

\section{Conceptual Water-Budget Summary}

A summary of the conceptual water budget is given in table 7. Recharge and flow to and from streams are the largest components. No attempt was made to balance the components of the conceptual budget.

\section{Simulation of Ground-Water Flow}

A three-dimensional, finite-difference, ground-water flow model program MODFLOW (McDonald and Harbaugh, 1988) was used to simulate ground-water flow and stream-aquifer interaction in the modeled area. The simulated results were used to:

- Determine recharge over the modeled area;

- Show general patterns of ground-water flow in the alluvial aquifer; and

- Determine the effects of various hypothetical groundwater pumping scenarios on ground-water levels and on streamflow in the Arkansas River.

Assumptions for MODFLOW are:

- Aquifer properties and stresses are distributed uniformly within a model cell and are constant during a stress period;
- The effects of aquifer stresses across the model boundaries are negligible;

- Tops and bottoms of model cells are horizontal, and the sides of cells are vertical; and

- Stream leakage to and from the aquifer is vertical.

Because the focus of this study was the Arkansas River and the adjacent alluvial aquifer in the area between Wichita and Arkansas City, a model grid was laid out with rows generally perpendicular to the river (fig. 24). The model grid consisted of 209 rows, 75 columns, and one layer for a total of 15,675 cells. One layer was used because the saturated thickness was less than $50 \mathrm{ft}$ in most of the modeled area (38-ft average) and no known laterally extensive confining material was present. Each cell was $1,320.5 \mathrm{ft}$ by $1,320.5 \mathrm{ft}$. The model grid was made large enough to take advantage of natural barriers to ground-water flow, such as the contact between shale and the alluvial deposits at the alluvial valley walls and to include the downstream reaches of the Ninnescah River and Slate Creek.

Various boundaries affect the geometry of the model. Noflow boundaries were simulated with no-flow cells where shale provides a natural boundary to ground-water flow on either side of the river valley. A no-flow boundary also was simulated beneath the alluvial aquifer where shale is considered a relatively impermeable boundary to ground-water flow. Water levels from Myers and others (1996) were used for the northern constant-head boundary. Water levels from the March 2001 water-table map (fig. 18A) were used for constant-head boundaries near the Ninnescah River and Slate Creek on the west, and near the Arkansas River on the south. The southeastern constant-head boundary was selected along a ground-water potentiometric divide. Stream cells in the model were located where streams exist to simulate the flux of water to or from the stream that is dependent on the difference between hydraulic head in the stream and the aquifer and the vertical hydraulic conductivity. Constant-head cells were used to simulate ground-water flow into or out of the modeled area where the alluvial aquifer extends laterally beyond the model limits. Active cells represented that part of the alluvial aquifer where water levels, saturated thickness, and ground-water flow were allowed to fluctuate.

The model used a steady-state assumption. This was considered reasonable because of little long-term change in water levels (fig. 19) and insufficient water-level and water-use data to show sufficient change to accurately calibrate a transient model. A consequence of the steady-state assumption is that any future hypothetical simulations can only examine long-term steady-state effects of changes in the system.

\section{Initial Model Conditions}

Aquifer properties defined for the flow model included horizontal hydraulic conductivity. The model developed by Myers and others (1996) for the upper layer of the Equus Beds aquifer between Hutchinson and Wichita was the primary 


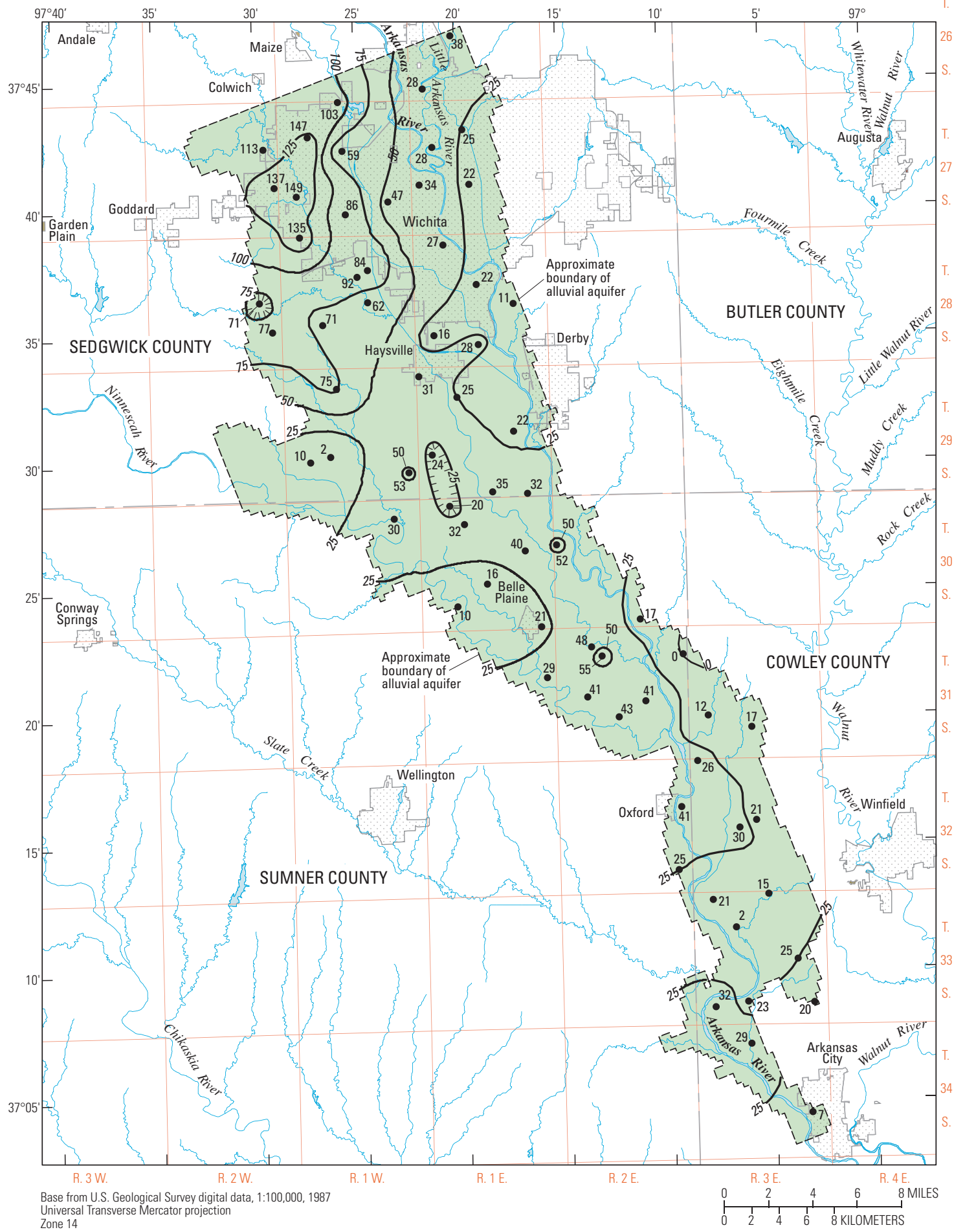

Horizontal coordinate information is referenced to the North American Datum of 1983 (NAD 83)

\section{EXPLANATION}

Approximate extent of alluvial deposits in modeled area

- 25- Approximate saturated thickness of alluvial aquifer, March 2001—Interval 25 feet

7- Alluvial aquifer thickness measurement site-Number is thickness of alluvial aquifer, in feet

Figure 20. (A) Approximate saturated thickness of the alluvial aquifer in the modeled area, March 2001. 


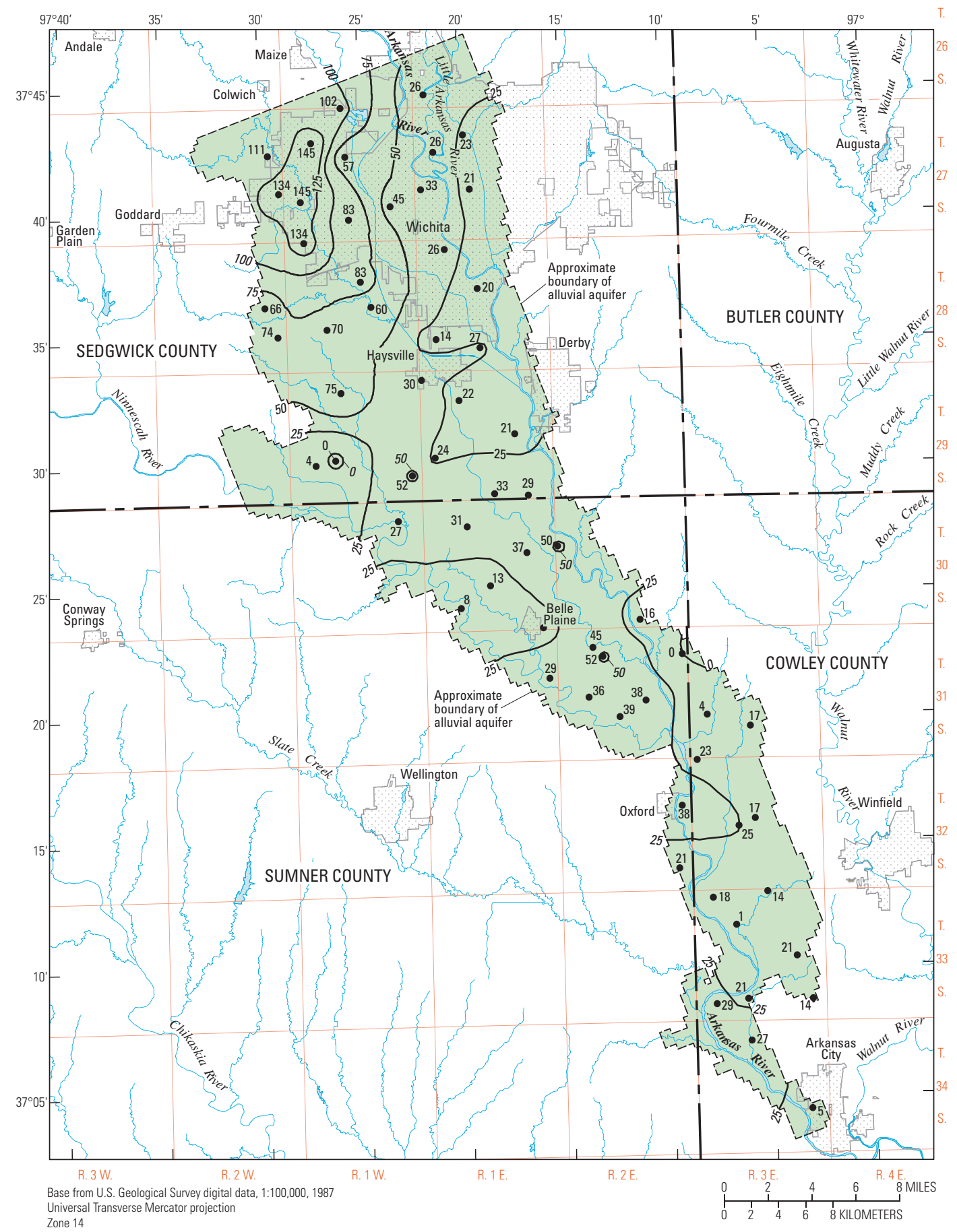

Zone 14

Horizontal coordinate information is referenced to the North American Datum of 1983 (NAD 83)

\section{EXPLANATION}

Approximate extent of alluvial deposits in modeled area

—25 - Approximate saturated thickness of alluvial aquifer, February 2002-Interval 25 feet

5• Alluvial aquifer thickness measurement site-Number is thickness of alluvial aquifer, in feet

Figure 20. (B) Approximate saturated thickness of the alluvial aquifer in the modeled area, February 2002. 

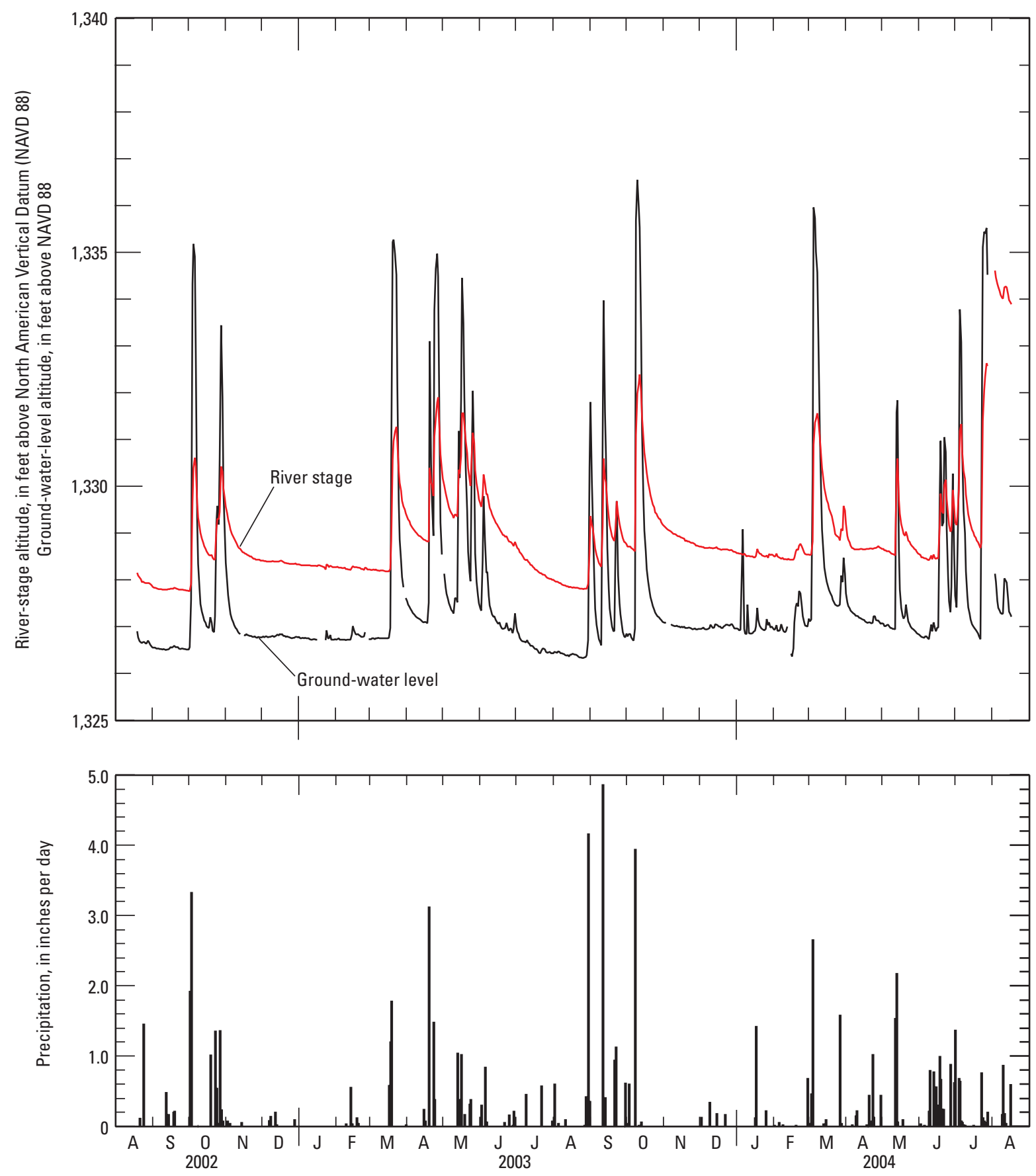

Figure 21. Daily mean river-stage altitude of Little Arkansas River at Valley Center (streamflow-gaging station 07144200), daily mean water-level altitude in nearby well (25S-01W-36BCCD-01), and daily precipitation at streamflow-gaging station, August 2002-August 2004. 


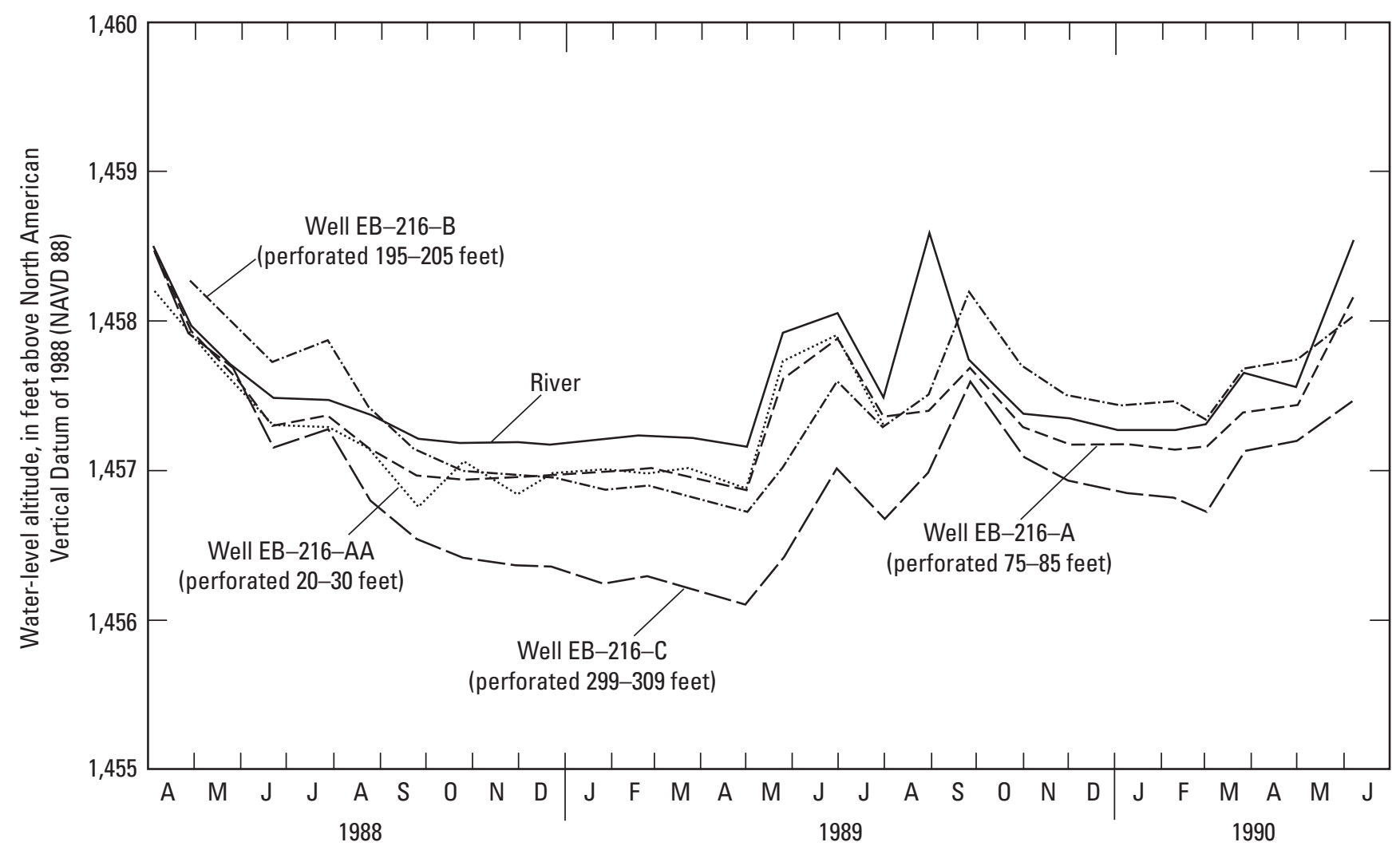

Figure 22. Monthly instantaneous ground-water levels in wells EB-216-AA, EB-216-A, EB-216-B, and EB-216-C and the mean daily river stage of the Arkansas River near Hutchinson (gaging station 0714330), April 1988-May 1990 (from Myers and others, 1996, fig. 16).

Table 6. Estimated net streamflow gain in modeled area of lower Arkansas River Basin, south-central Kansas, 1940-2001.

[All values are in cubic feet per second]

\begin{tabular}{|c|c|c|c|c|}
\hline $\begin{array}{c}\text { Station } \\
\text { identification } \\
\text { number } \\
\text { (fig. 8) }\end{array}$ & Station name & $\begin{array}{c}\text { Median flow, } \\
\text { 1940-2001 }\end{array}$ & $\begin{array}{l}\text { Base flow, } \\
\text { 1940-2001 }\end{array}$ & $\begin{array}{l}\text { Base flow, } \\
1970-2001\end{array}$ \\
\hline \multirow[t]{2}{*}{07146500} & Arkansas River at Arkansas City, Kansas & 1,060 & 1,025 & 1,034 \\
\hline & Total stream outflow & 1,060 & 1,025 & 1,034 \\
\hline 07144300 & Arkansas River at Wichita, Kansas & 474 & 490 & 460 \\
\hline 07144480 & Cowskin Creek at 119th Street at Wichita, Kansas & 3 & 3 & 3 \\
\hline 07145500 & Ninnescah River near Peck, Kansas & 245 & 279 & 304 \\
\hline \multirow[t]{7}{*}{07145700} & Slate Creek at Wellington, Kansas & 8 & 11 & 11 \\
\hline & Tributaries to Cowskin Creek & 8 & 7 & 7 \\
\hline & Tributaries to Ninnescah River & 3 & 3 & 3 \\
\hline & Tributaries to Arkansas River & 15 & 12 & 12 \\
\hline & Wichita wastewater treatment plant & 63 & 63 & 63 \\
\hline & Total stream inflow & 819 & 868 & 863 \\
\hline & Net streamflow gain & 241 & 157 & 171 \\
\hline
\end{tabular}




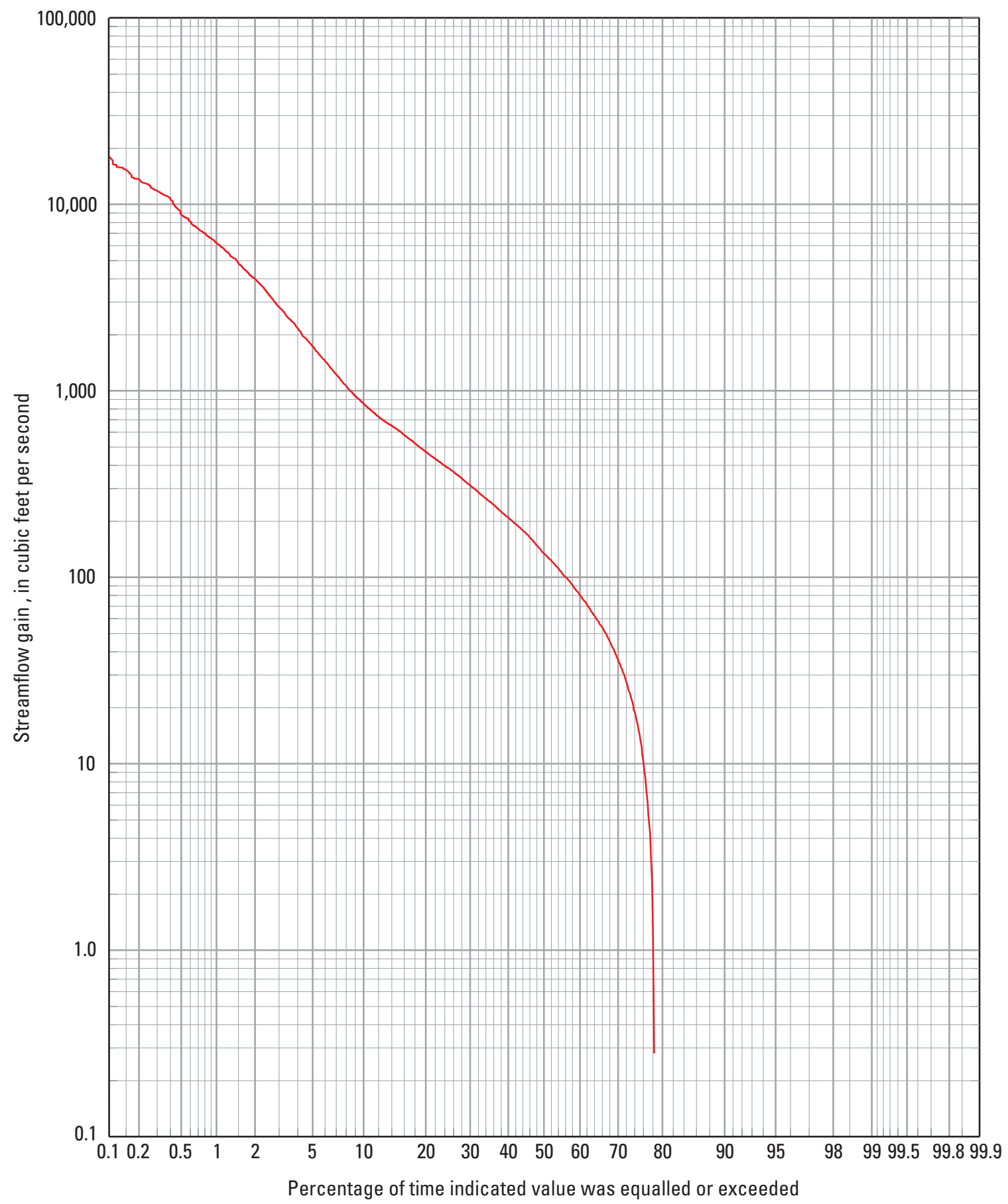

Figure 23. Duration curve of estimated streamflow gains for Arkansas River between Wichita (gaging station 07144300) and Arkansas City (gaging station 07146500, fig. 8), Kansas, 1940-2001.

source of initial aquifer property data. The starting horizontal hydraulic conductivity used in the modeled area was $750 \mathrm{ft} / \mathrm{d}$.

\section{Stresses}

Stresses simulated in the steady-state ground-water flow model included recharge, stream leakage, and pumpage by wells. Recharge was chosen initially to be 5 in. everywhere because that was near the midpoint of the range of values reported in previous studies and somewhat greater than Spinazola and others (1985) and Myers and others (1996) used in their slightly more arid study areas to the northwest. Stream leakage was simulated by calculating a streambed-

conductance term on the basis of the length and width of each stream reach (one stream reach for each model cell), the thickness of the streambed, and the vertical hydraulic conductivity of the streambed and is expressed by the equation (McDonald and Harbaugh, 1988, p. 6-4):

$$
\text { criv }=\frac{K L W}{M}
$$


Table 7. Summary of conceptual water budget.

$[+$, indicates inflow to the aquifer in the modeled area; -, indicates outflow from the aquifer in the modeled area]

\begin{tabular}{lc}
\hline Water-budget component & $\begin{array}{c}\text { Net inflow } \\
\text { (cubic feet per } \\
\text { second) }\end{array}$ \\
\hline Recharge & +146 \\
Net lateral inflow/outflow across & +56 \\
$\quad$ boundary & -157 \\
Net flow to/from streams & -56 \\
Ground-water pumpage & -11 \\
\hline Net difference & \\
\hline
\end{tabular}

where

criv = streambed conductance, in feet squared per day;

$K=$ vertical hydraulic conductivity of the streambed, in feet per day;

$L=$ length of stream reach, in feet;

$\mathrm{W}=$ width of stream reach, in feet; and

$M=$ thickness of streambed, in feet.

The length of each stream reach was set equal to the cumulative length of the stream or streams in each model cell. The width of the streams was estimated by onsite observation. Because no discrete streambed could be identified, the thickness of the streambeds was assumed to be $1 \mathrm{ft}$. The initial values of vertical hydraulic conductivity of streambeds were assigned similar to Myers and others (1996) assuming that the Arkansas River would have the largest vertical hydraulic conductivity. The initial streambed vertical hydraulic-conductivity values used in the model were $50 \mathrm{ft} / \mathrm{d}$ for the Arkansas River; $15 \mathrm{ft} / \mathrm{d}$ for the Little Arkansas River; and $1 \mathrm{ft} / \mathrm{d}$ for Slate Creek, Cowskin Creek, and the Ninnescah River.

In addition to the aquifer properties just mentioned, streambed slope, top-of-streambed altitude, and bottom-ofstreambed altitude were used to calculate stream stage in each stream cell. Streambed slope and top-of-streambed altitude were determined from USGS 7.5-minute topographic maps. Assuming that there has not been any significant aggradation or degradation of streambed altitude since the topographic maps were made, the streambed altitude used in the model probably is accurate to $\pm 2.5 \mathrm{ft}$ (one-half of the contour interval).

Well pumpage was simulated in the steady-state model using average reported 1998-2001 ground-water withdrawals. Reported average ground-water withdrawals for 1998-2001 simulated in the steady-state model were about $56 \mathrm{ft}^{3} / \mathrm{s}$ and were applied to appropriate model cells as shown in figure 25 .

\section{Model Calibration}

The purpose of calibration is to refine the model so that it is a reasonable representation of the stream-aquifer system. Calibration was achieved by adjusting the values of recharge and aquifer hydraulic conductivity, within reasonable ranges, to achieve the best fit between measured March 2001 groundwater levels and simulated ground-water levels that resulted from average 1998-2001 reported ground-water use $\left(56 \mathrm{ft}^{3} / \mathrm{s}\right)$ and computed streamflow gain $\left(157 \mathrm{ft}^{3} / \mathrm{s}\right)$. Recharge was increased from 5 to $8 \mathrm{in}$. along the valley wall boundaries to achieve a better match with aquifer water levels and to achieve a reasonable water balance with computed streamflow gain. This added recharge represents seepage that occurs at the valley wall interface that is otherwise unaccounted for. Aquifer hydraulic conductivity was decreased areally especially toward the south and near the valley walls. The final model-calibrated recharge (5.4 in.) and aquifer hydraulic conductivity (average of $509 \mathrm{ft} / \mathrm{d}$ ) values are shown in figures 26 and 27, respectively. Streambed conductance was not adjusted during calibration.

A map showing simulated saturated thickness of the alluvial aquifer that resulted from using average reported groundwater withdrawals for 1998-2001 is shown in figure 28. This map is somewhat similar to the map drawn using the difference between measured March 2001 ground-water levels and the altitude of the bedrock surface, except in the northwest and southeast near the valley walls where the water-level fit was poorest (see fig. 29).

The measure of model calibration is the fit between modelcalibrated water levels and measured water levels as well as the comparison of model-computed and measured/computed parameters. The comparison of the two water-level surfaces is shown in figure 29. It shows reasonable agreement in most areas with the weakest fit achieved near the valley wall in the northwestern, southern, and southeastern parts of the modeled area. Model calibration is least certain near boundaries and especially in the extreme southern part of the modeled area where the model grid is only a few cells wide and there are large pumping centers. The mean absolute difference between the 66 measured water levels in March 2001 and the model-calibrated-water levels was $3.87 \mathrm{ft}$, whereas the mean difference was $0.3 \mathrm{ft}$ less than March 2001 water levels. Of the 66 measured water-level points, 3 simulated water levels differed by 10 to $15 \mathrm{ft}$; all others differed by less than $10 \mathrm{ft}$ (see fig. 30).

The final simulated steady-state water budget is summarized in table 8 . The computed streamflow gain (table 6) of $157 \mathrm{ft}^{3} / \mathrm{s}$ compares favorably with the simulated net aquifer to streamflow gain of $164 \mathrm{ft}^{3} / \mathrm{s}$ (outflow $191 \mathrm{ft}^{3} / \mathrm{s}$ minus seepage inflow $27 \mathrm{ft}^{3} / \mathrm{s}$, table 8 ). The final simulated model water budget (table 8 ) is very similar to the conceptual water budget (table 7).

Model calibrations are not unique. This calibration probably represents a reasonable maximum for recharge because the water levels used were from a period of above-average streamflow and probably above-average ground-water levels and simulated streamflow gain were greater than computed (164 compared to $157 \mathrm{ft}^{3} / \mathrm{s}$ ). The model was also run using all parameters the same as during the calibrated model except recharge was selected as $4.7 \mathrm{in}$. This simulation resulted in a mean absolute water-level difference of $4.28 \mathrm{ft}$, a mean waterlevel difference of $1.3 \mathrm{ft}$ below March 2001 measured water levels $(0.1 \mathrm{ft}$ below the average of the high, March 2001, and low, February 2002, water levels), and a streamflow gain of $145 \mathrm{ft}^{3} / \mathrm{s}$. This simulation probably represents a reasonable 


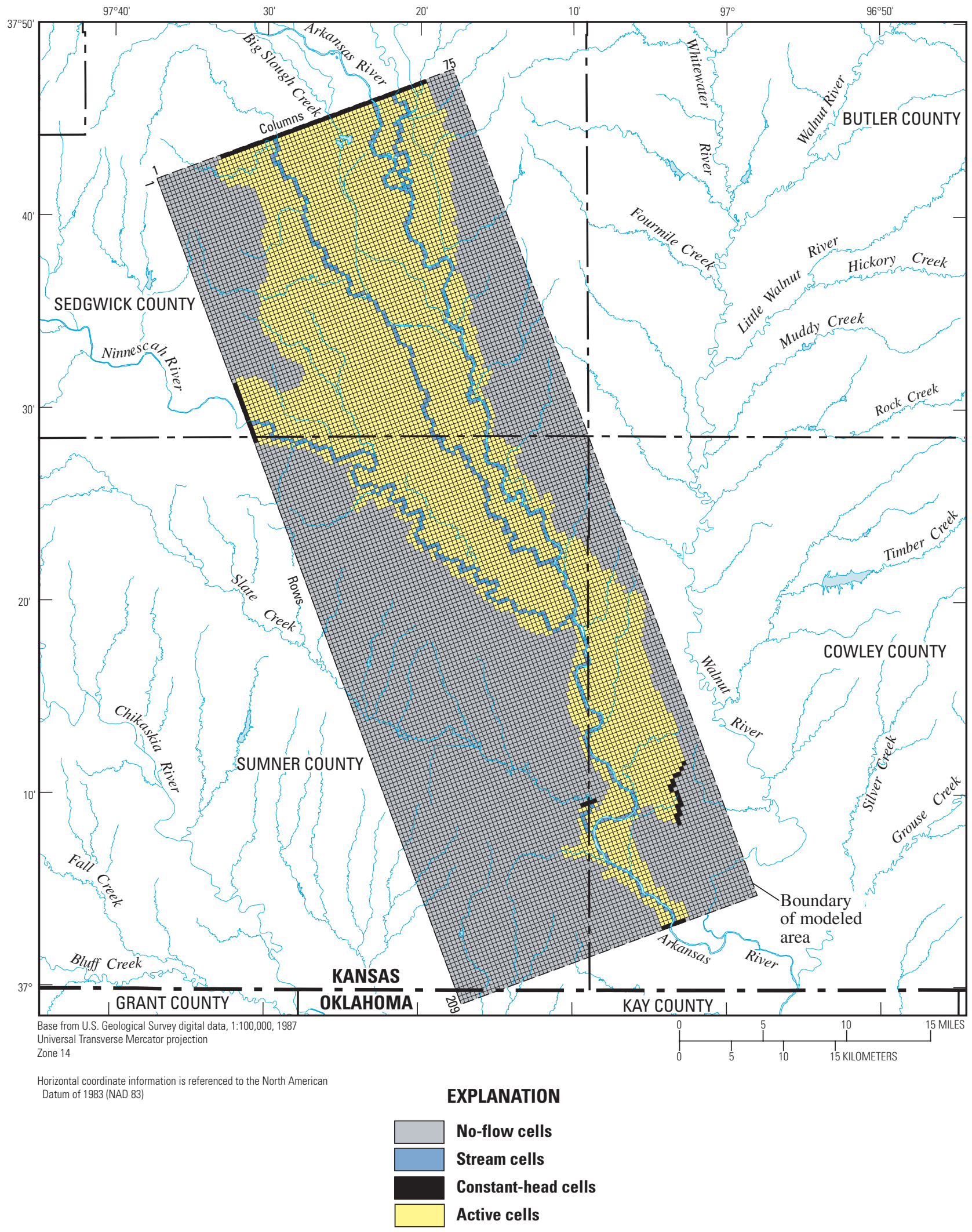

Figure 24. Finite-difference grid and boundary conditions used in model analyses. 


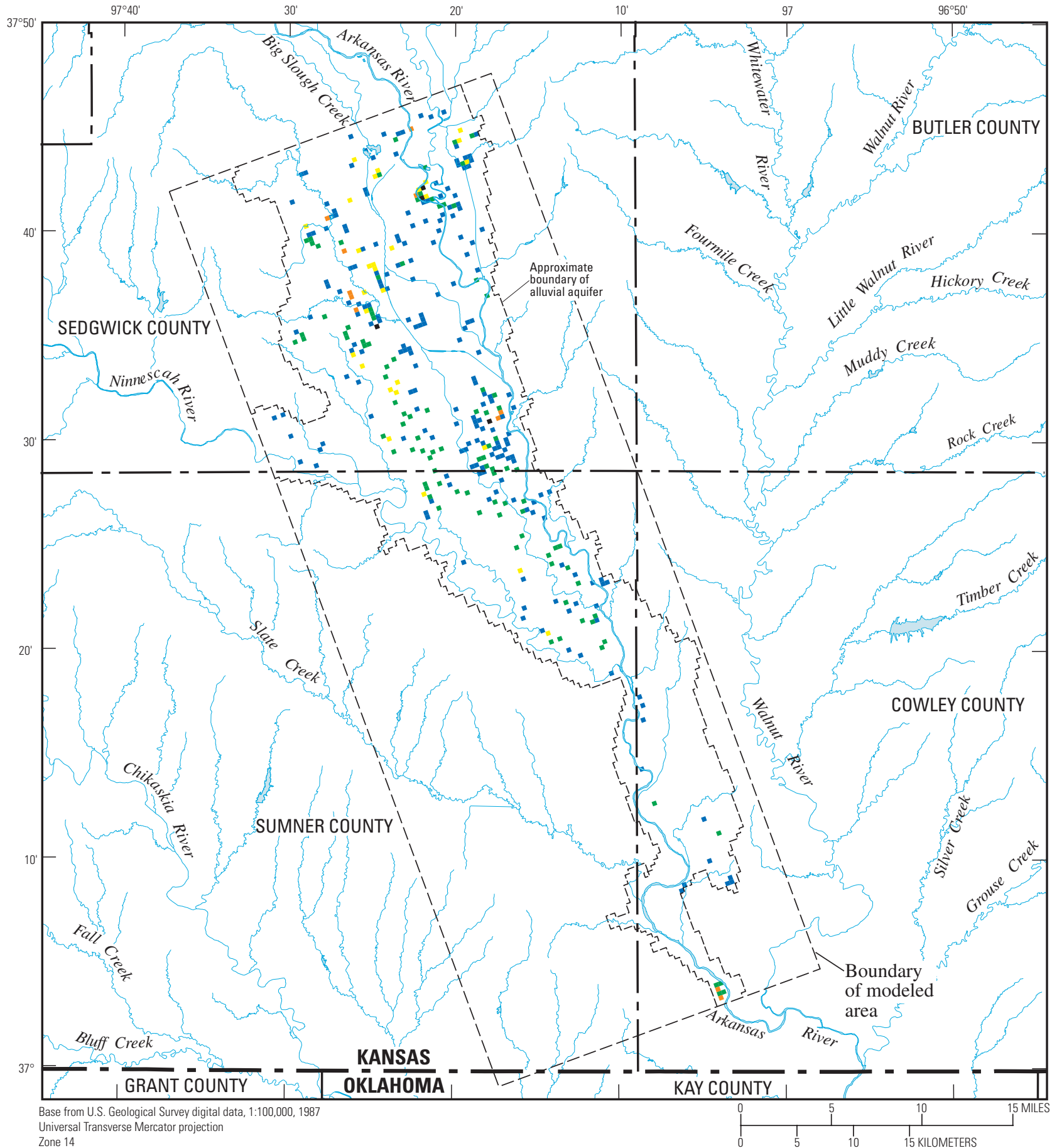

Horizontal coordinate information is referenced to the North American Datum of 1983 (NAD 83)

EXPLANATION

Average volume of ground-water withdrawals, in acre-feet per year

\begin{tabular}{|c|c|c|}
\hline $0-100$ & $201-500$ & $1,001-2,000$ \\
\hline $101-200$ & $501-1,000$ & No well located in \\
\hline
\end{tabular}

Figure 25. Distribution of average volume of ground-water withdrawals from modeled area reported for 1998-2001 (data from Kansas Department of Agriculture, Division of Water Resources, Topeka, Kansas, written commun., 2003). 


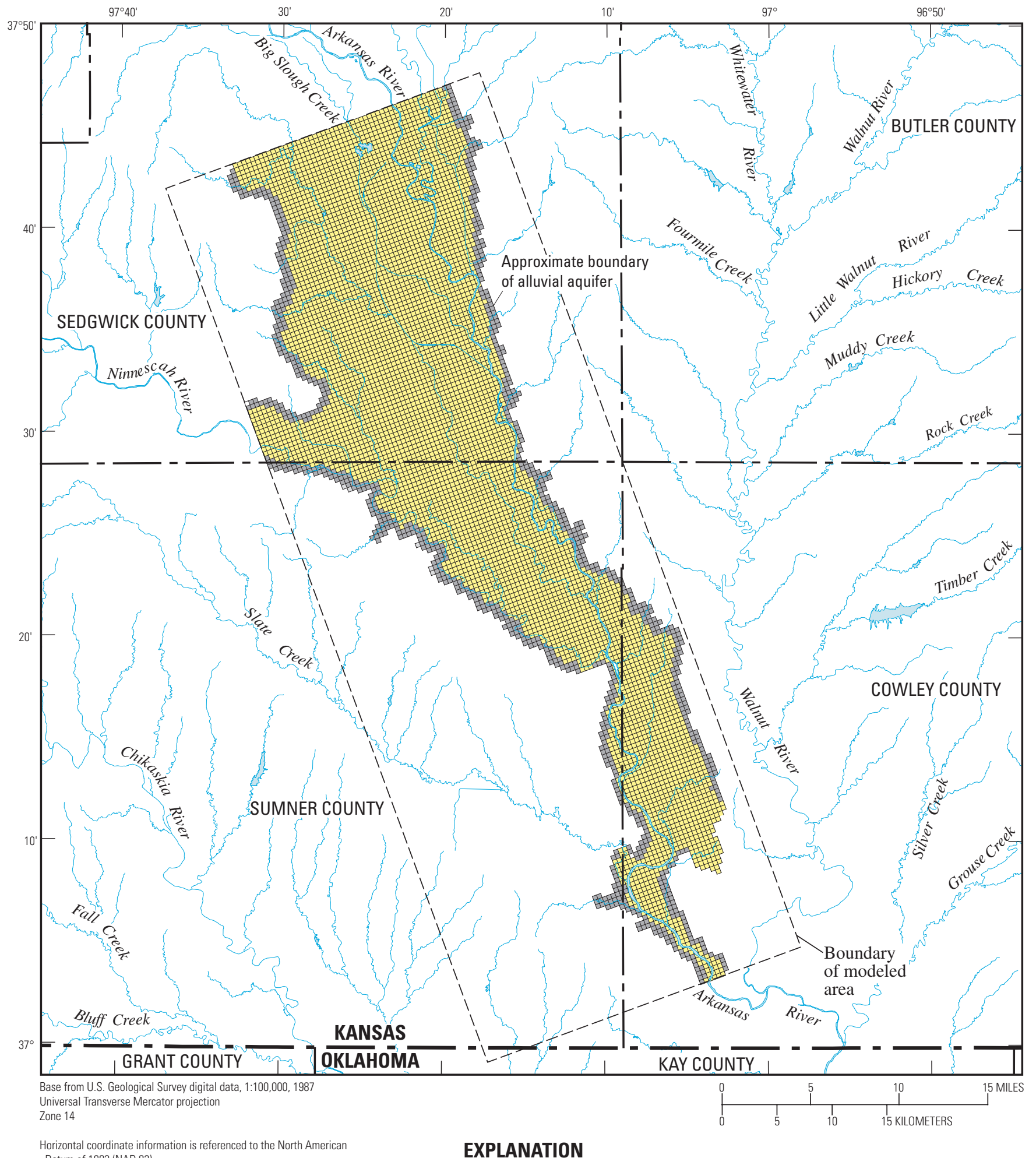

Calibrated recharge, in inches per year

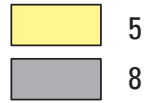

Figure 26. Calibrated ground-water recharge rates for modeled area. 


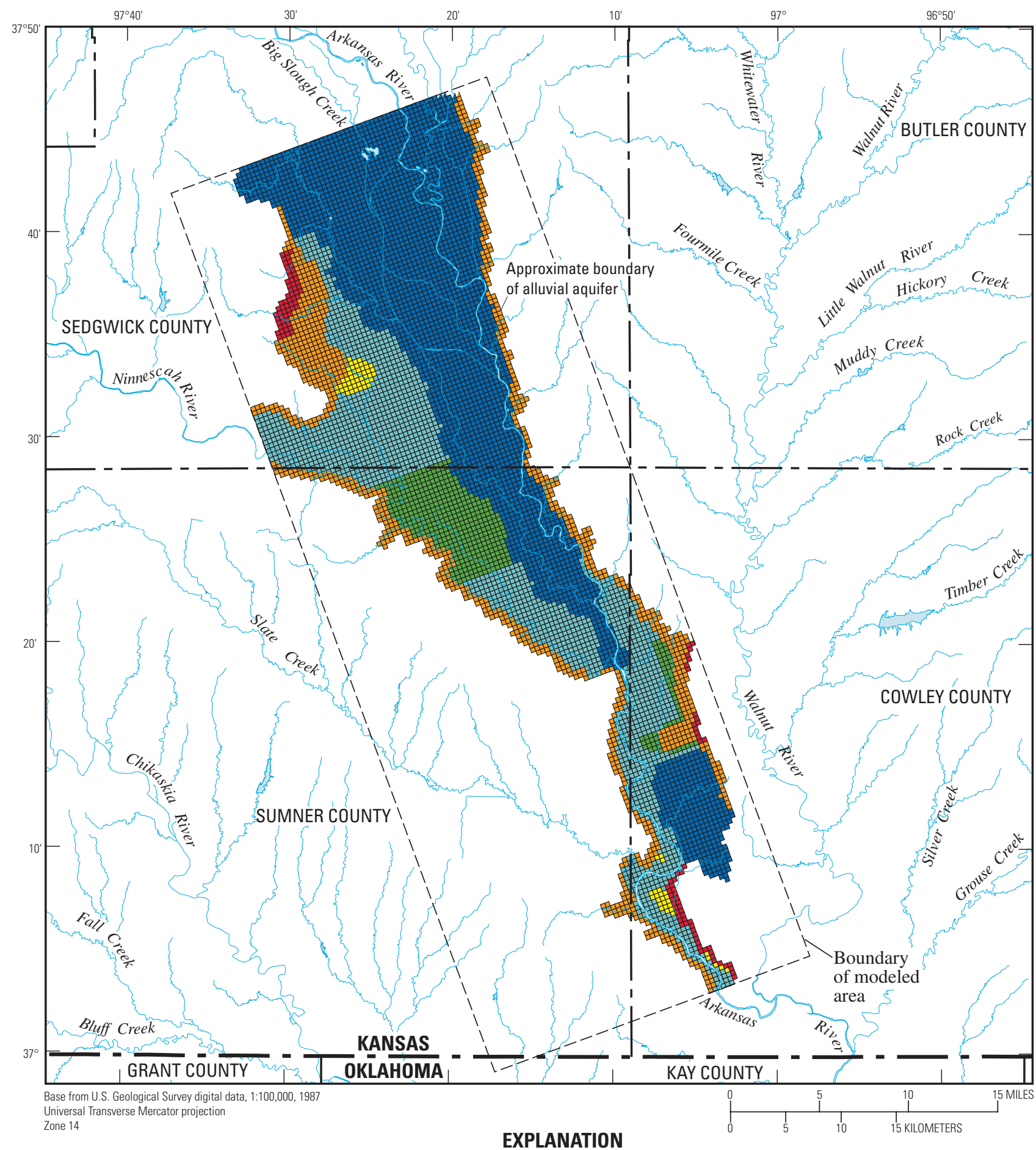

Horizontal coordinate information is referenced to the North American Datum of 1983 (NAD 83)

Horizontal hydraulic conductivity, in feet per day

\begin{tabular}{|c|c|}
\hline 0-10 & 101-300 \\
\hline $11-50$ & 301-500 \\
\hline 51-100 & 501-750 \\
\hline
\end{tabular}

Figure 27. Distribution of horizontal hydraulic conductivity in modeled area. 


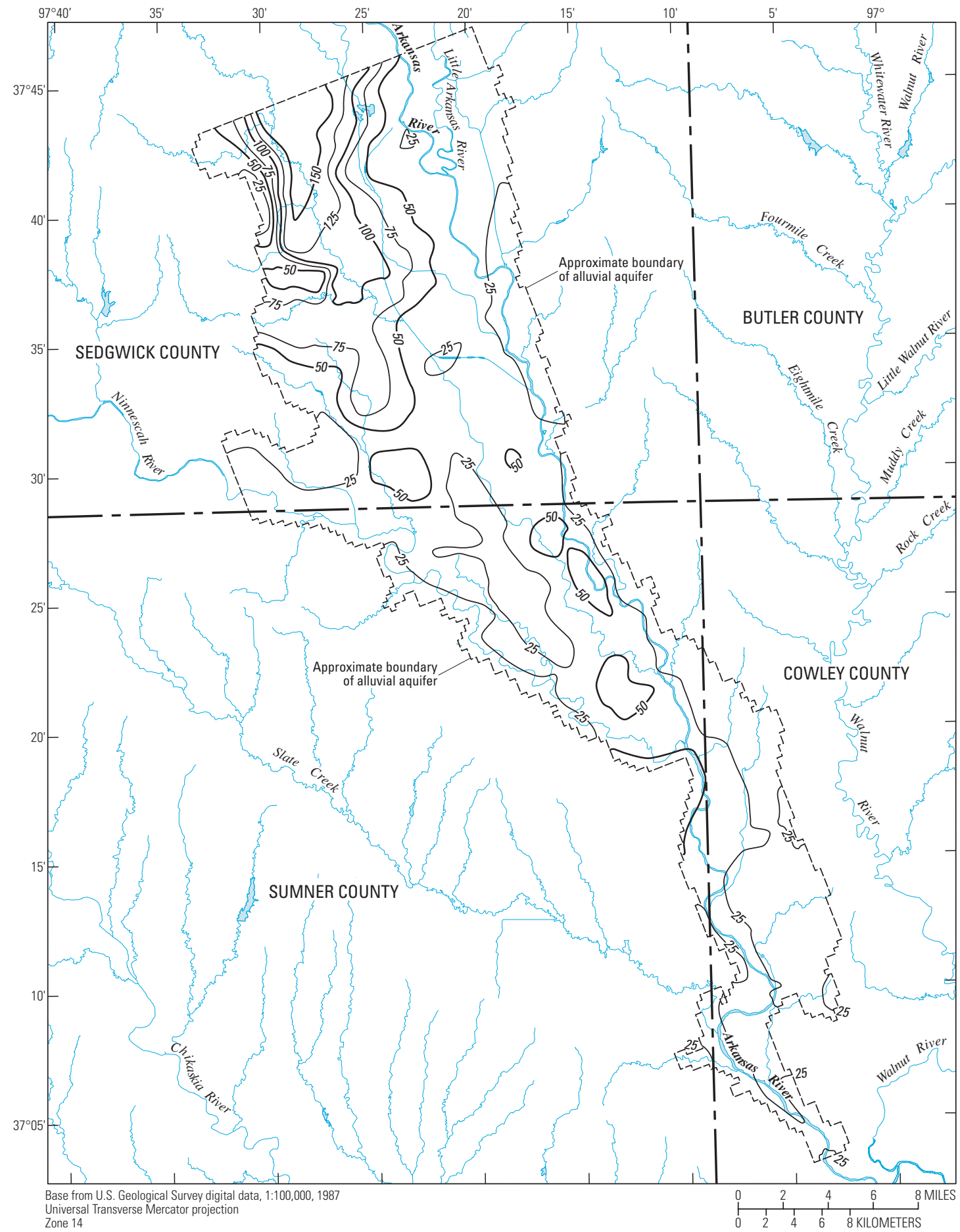

Horizontal coordinate information is referenced to the North American Datum of 1983 (NAD 83)

EXPLANATION

- 50 - Line of equal simulated saturated thickness - Interval 25 feet

Figure 28. Simulated saturated thickness of alluvial aquifer in modeled area with average reported groundwater withdrawals for 1998-2001 (40,552 acre-feet per year). Reported ground-water withdrawals from Kansas Department of Agriculture, Division of Water Resources, written commun., 2003. 


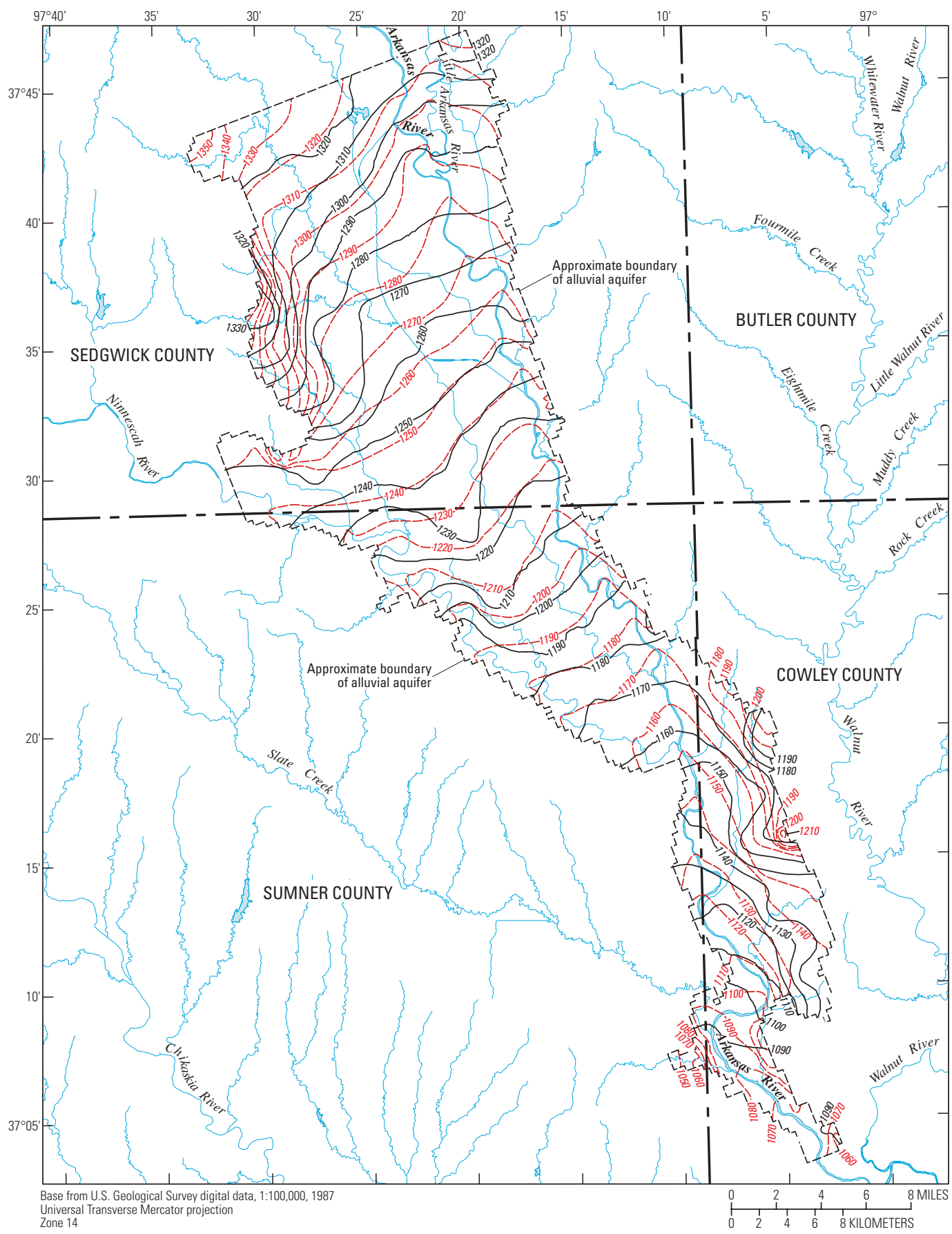

Horizontal coordinate information is referenced to the North American Datum of 1983 (NAD 83)

\section{EXPLANATION}

\section{- 1070- Measured water-table contour-Shows altitude of measured water table, March 2001. Contour inteval 10 feet. Datum is North American Vertical Datum of 1988 \\ ---1070---Simulated water-table contour-Shows altitude of simulated water table using average reported ground-water withdrawals for 1998-2001. Contour inteval 10 feet. Datum is North American Vertical Datum of 1988}

Figure 29. Comparison of measured water-level altitudes for March 2001 and simulated water-level altitudes with average reported ground-water withdrawals for 1998-2001. 


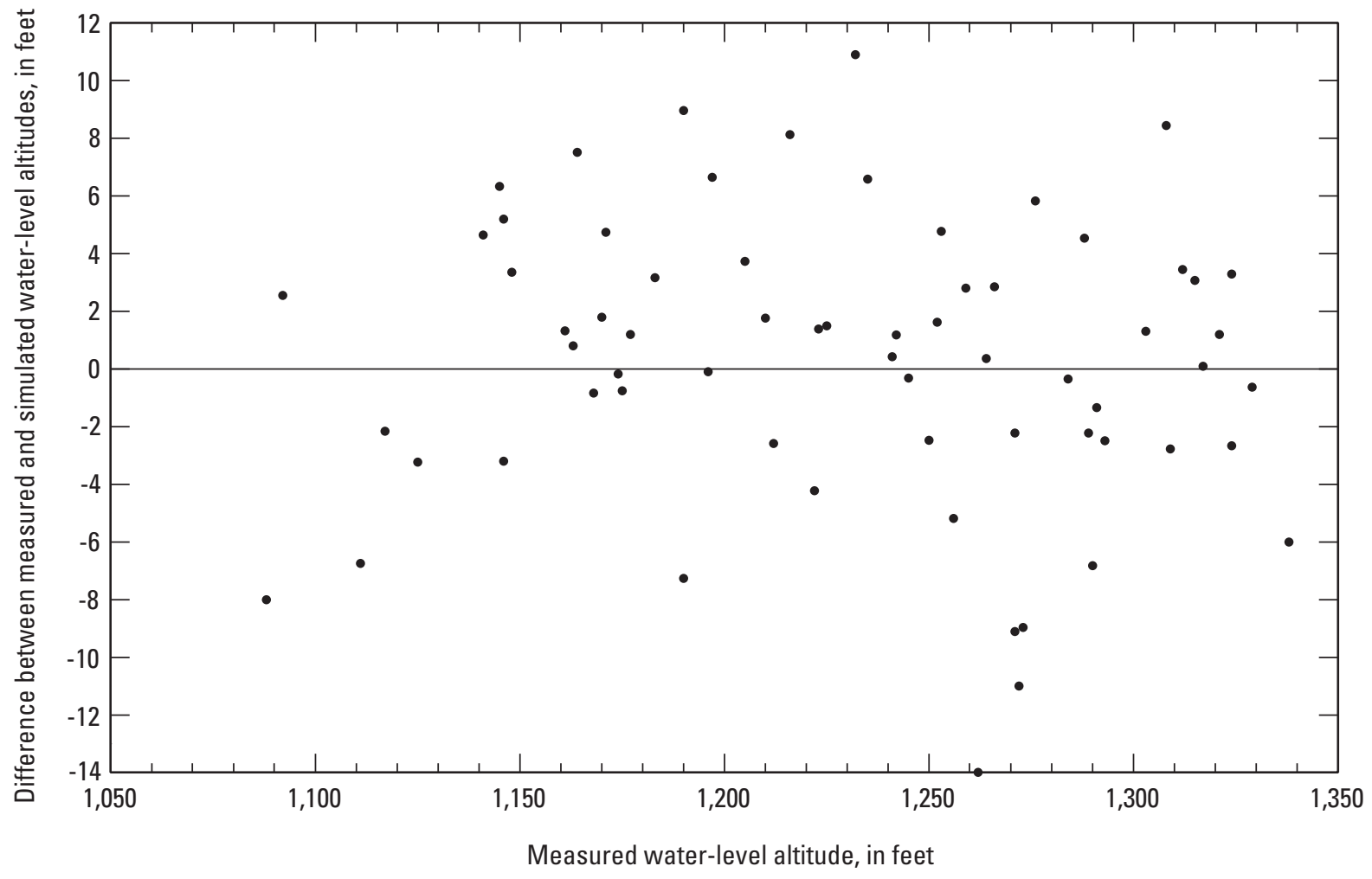

Figure 30. Differences between measured and simulated water-level altitudes, March 2001.

Table 8. Simulated steady-state water budget for Arkansas River alluvial aquifer in modeled area, Cowley, Sedgwick, and Sumner Counties, south-central Kansas.

[All values are in cubic feet per second]

\begin{tabular}{lc}
\hline \multicolumn{1}{c}{ Budget term } & Steady state \\
\hline \multicolumn{1}{c}{ Inflow } \\
Recharge & 166 \\
Ground-water inflow from adjacent areas & 54 \\
Seepage from Arkansas and Ninnescah & 27 \\
Rivers to alluvial aquifer & \\
Total inflow & $\mathbf{2 4 7}$ \\
$\quad$ Outflow & \\
Ground-water outflow to adjacent areas & 2 \\
Seepage from the alluvial aquifer to the & 191 \\
Arkansas and Ninnescah Rivers & 154 \\
Well pumpage & $\mathbf{2 4 7}$ \\
Total outflow &
\end{tabular}

\footnotetext{
${ }^{1}$ Simulated well pumpage differs from actual well pumpage because a few active model cells were dry during the simulation.
}

minimum for average recharge over the modeled area. As a result, recharge in the modeled area is probably between 4.7 and 5.4 in. averaged over the area.

\section{Sensitivity Analysis}

The purpose of sensitivity analysis is to measure how sensitive the calibrated model-computed results are to changes in aquifer properties and aquifer stresses. During sensitivity analysis, recharge and hydraulic conductivity were varied from onequarter to twice their calibration values, and streambed conductance varied from multiples of 0.01 to 100 times the calibration values. The resulting simulated hydraulic heads were used to calculate the mean deviation of water levels for each active model cell from the calibrated model heads (fig. 31).

Changes in the rate of recharge and values of hydraulic conductivity had the most effect on the mean absolute deviation from the accepted calibration hydraulic heads, whereas changes in streambed conductance had little effect. Doubling the values of recharge and hydraulic conductivity changed the mean absolute deviation by about 4 and $2 \mathrm{ft}$, respectively. These relatively small changes are an indication that water-level changes in the alluvial aquifer are constrained by the presence of the Arkansas River, by the generally shallow depth of the water table below land surface, and the large hydraulic conductivity of the aquifer material. That is, water levels in the aquifer near the Arkansas River cannot decline or rise much below or above the level of water in the river without large amounts of water moving between the river and the aquifer, and water cannot rise above land surface without running off. Thus, water levels in the alluvial aquifer are constrained under natural or at least not excessive pumping conditions to a relatively small range. In such a constrained system, a larger range of aquifer properties and 


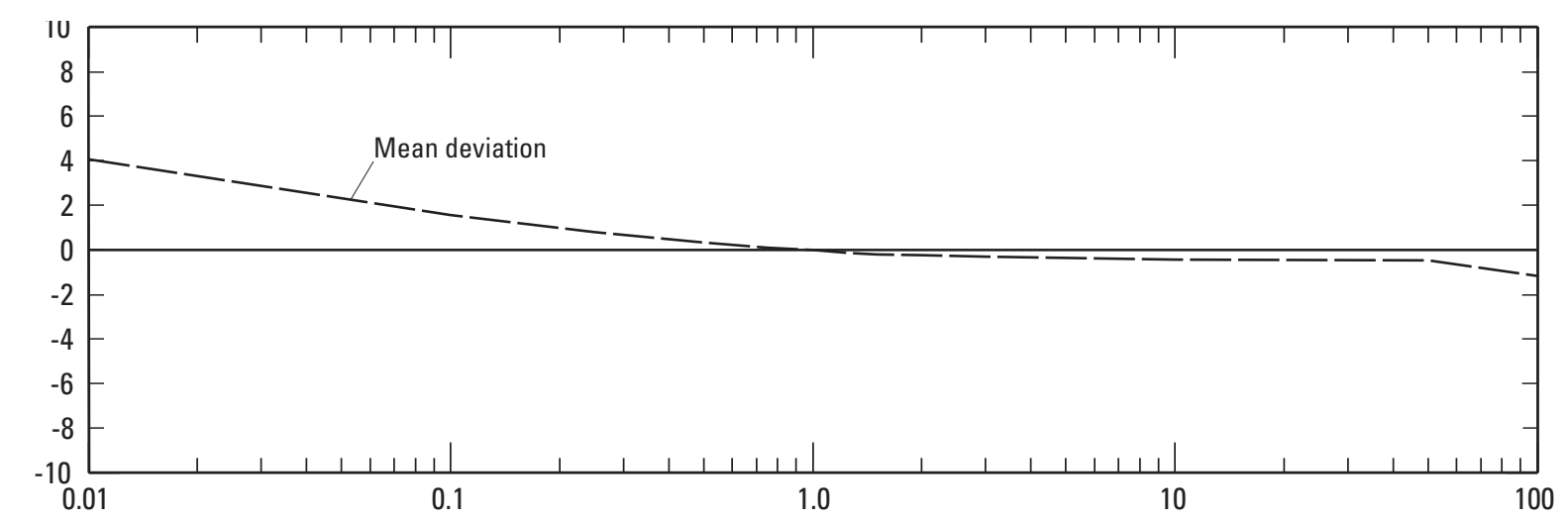

(B) Recharge

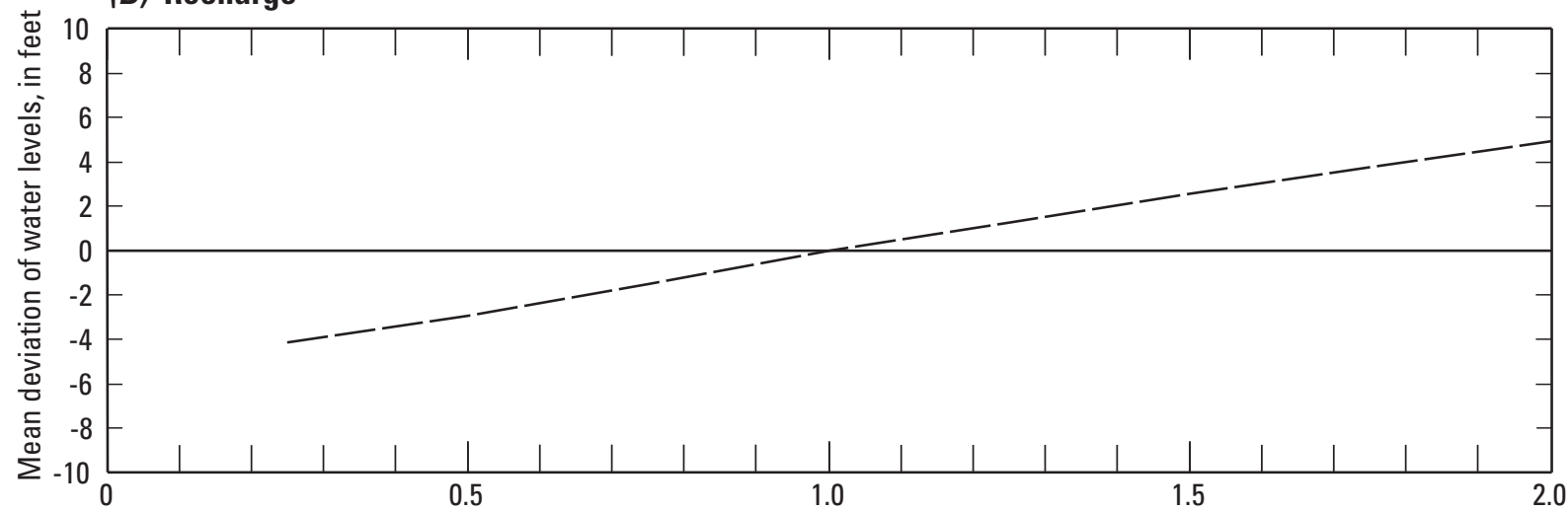

(C) Hydraulic conductivity

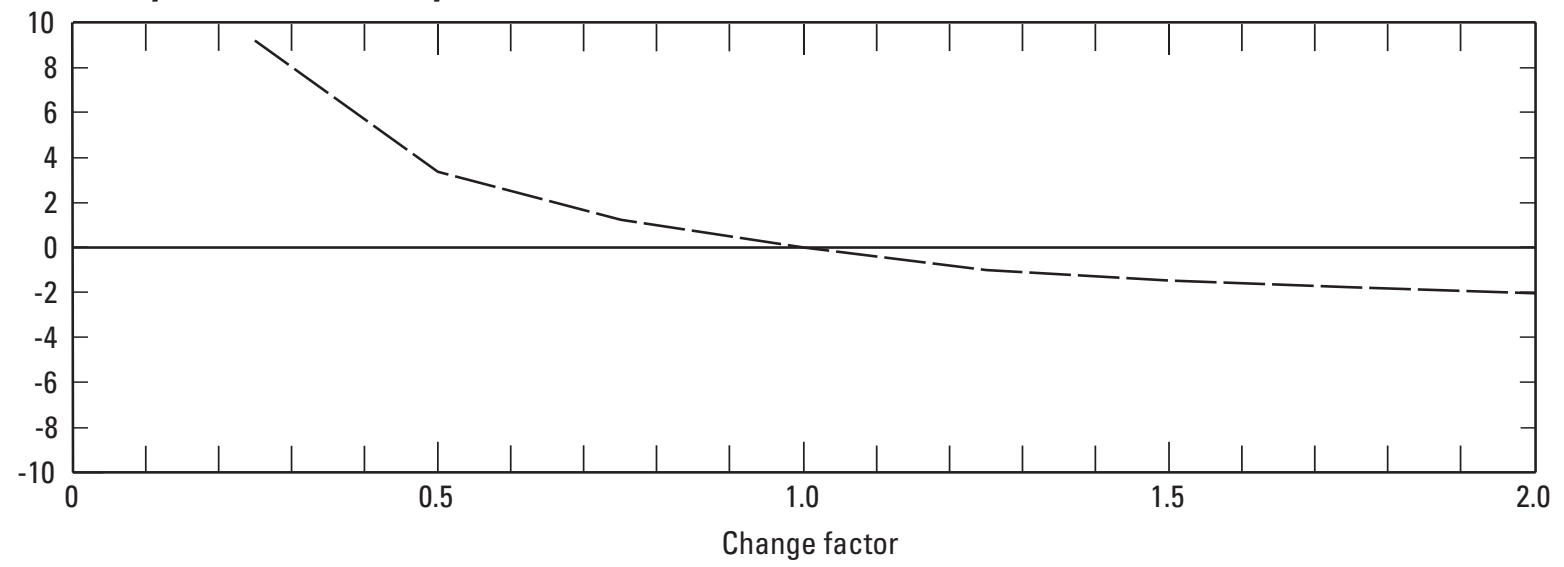

Figure 31. Mean deviations of simulated hydraulic heads from accepted model-calibration heads for changes in $(A)$ streambed conductance, $(B)$ recharge, and $(C)$ hydraulic conductivity.

stresses will satisfy a given hydraulic-head distribution than in a less-constrained system. The hydraulic parameters and boundary conditions used to represent the stream-aquifer system are not unique but represent one of many possible solutions.

\section{Hypothetical Simulations}

A series of nine hypothetical simulations was used to estimate the possible effects of changing well pumpage on groundwater levels and saturated thickness of the alluvial aquifer. All boundary conditions and aquifer properties for the model were the same as those previously discussed. Pumpage and the other water-budget components from these steady-state simulations of hypothetical conditions are summarized in table 9. The areal effects of the different pumping scenarios are summarized by a simulated aquifer thickness map for each scenario (fig. $32 A-J$ ). The accuracy of thickness maps from these simulations is less in the areas where the calibration of water levels deviated most from that contoured using water-level measurements near the northwestern and southeastern valley walls and probably in areas of minimal aquifer thickness (less than $25 \mathrm{ft}$ ). Because of 
Table 9. Simulated steady-state water budgets used in hypothetical simulations of alluvial aquifer in lower Arkansas River Basin, south-central Kansas.

[values are in cubic feet per second]

\begin{tabular}{|c|c|c|c|c|c|c|}
\hline & \multirow[b]{2}{*}{ Pumping scenario } & \multirow[b]{2}{*}{$\begin{array}{l}\text { Distribution of } \\
\text { ground-water } \\
\text { withdrawals }\end{array}$} & \multicolumn{4}{|c|}{ Water-budget term } \\
\hline & & & $\begin{array}{c}\text { Well } \\
\text { pumpage }^{1}\end{array}$ & $\begin{array}{l}\text { Net } \\
\text { streamflow } \\
\text { gain }\end{array}$ & Recharge $^{1}$ & Boundary flow \\
\hline Calibration & $\begin{array}{l}\text { Pumping at average ground- } \\
\text { water use reported for 1998- } \\
2001\end{array}$ & Reported use & 54 & 164 & 166 & 52 \\
\hline \multicolumn{7}{|c|}{$\begin{array}{l}\text { Hypothetical } \\
\text { simulation } \\
\text { identification }\end{array}$} \\
\hline $\mathrm{A}$ & No pumping & -- & 0 & 216 & 166 & 50 \\
\hline B & $\begin{array}{l}\text { Pumping at the } 2002 \text { ground- } \\
\text { water use }\end{array}$ & Reported use & 50 & 168 & 166 & 52 \\
\hline $\mathrm{C}$ & $\begin{array}{l}\text { Pumping at the current (2004) } \\
\text { authorized ground-water } \\
\text { use }^{2}\end{array}$ & Authorized use & 106 & 113 & 165 & 54 \\
\hline $\mathrm{D}$ & $\begin{array}{l}\text { Pumping at about } 10 \text { percent } \\
\text { more than the current (2004) } \\
\text { authorized ground-water use }\end{array}$ & Authorized use & 116 & 103 & 165 & 54 \\
\hline $\mathrm{E}$ & $\begin{array}{l}\text { Pumping at about } 25 \text { percent } \\
\text { more than the current (2004) } \\
\text { authorized ground-water use }\end{array}$ & Authorized use & 132 & 88 & 165 & 55 \\
\hline $\mathrm{F}$ & $\begin{array}{l}\text { Pumping at about } 50 \text { percent } \\
\text { more than the current (2004) } \\
\text { authorized ground-water use }\end{array}$ & Authorized use & 158 & 57 & 158 & 56 \\
\hline $\mathrm{G}$ & $\begin{array}{l}\text { Pumping at about } 75 \text { percent } \\
\text { more than the current (2004) } \\
\text { authorized ground-water use }\end{array}$ & Authorized use & 184 & 31 & 157 & 58 \\
\hline $\mathrm{H}$ & $\begin{array}{l}\text { Pumping at about } 100 \text { percent } \\
\text { more than current (2004) } \\
\text { authorized ground-water use }\end{array}$ & Authorized use & 206 & 9 & 156 & 59 \\
\hline I & $\begin{array}{l}\text { Pumping at Hansen (1991) } \\
\text { recharge rates in each model } \\
\text { cell. These values are used } \\
\text { by Kansas Department of } \\
\text { Agriculture, Division of } \\
\text { Water Resources, as safe } \\
\text { yield. }\end{array}$ & $\begin{array}{l}\text { Based on recharge } \\
\text { distribution }\end{array}$ & 84 & 130 & 157 & 57 \\
\hline
\end{tabular}

${ }^{1}$ Small differences in well pumpage and recharge are a result of some model cells being dry in some simulations.

${ }^{2}$ Authorized ground-water use from Kelly Emmons, Kansas Department of Agriculture, Division of Water Resources, January 16, 2004.

the steady-state assumption, the results of these hypothetical simulations apply to the long-term average effect of pumpage at the noted quantity and distribution.

The difference in aquifer thickness for most of the nine hypothetical simulations is relatively small. Some differences in simulated aquifer thickness are evident in the simulations that projected larger pumping rates (simulations $\mathrm{F}-\mathrm{H}$, fig. 32 and table 9) especially in the northern part of the modeled area where most of the authorized pumpage is located. However, because only simulation I used a substantially different pumpage distribution scheme, simulations $\mathrm{A}$ through $\mathrm{H}$ have similar saturated thickness patterns. Simulation I has a greater percentage of pumpage in the southern part of the modeled area relative to the other simulations, and some effects of that distribution can be observed in the thickness map (fig. 32I). The effect of increased pumping on Arkansas River streamflow gain is more notable (table 9). Doubling the authorized ground-water pumpage decreases streamflow gain from 168 to $9 \mathrm{ft}^{3} / \mathrm{s}$ or 95 percent. 


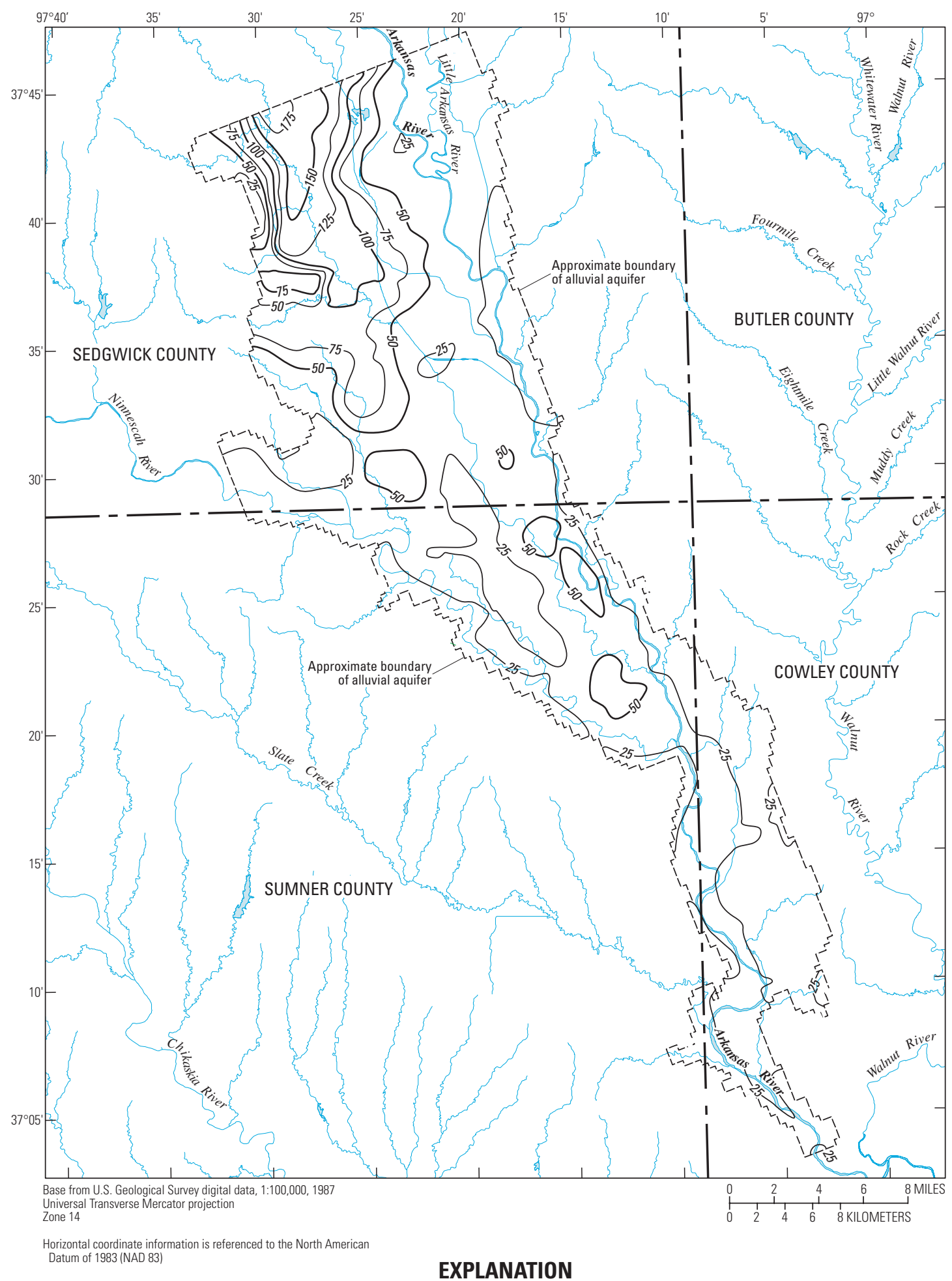

- 50- Line of equal saturated thickness-Interval 25 feet

Figure 32. (A) Simulated saturated thickness of alluvial aquifer in modeled area using pumping at average ground-water use reported for 1998-2001. 


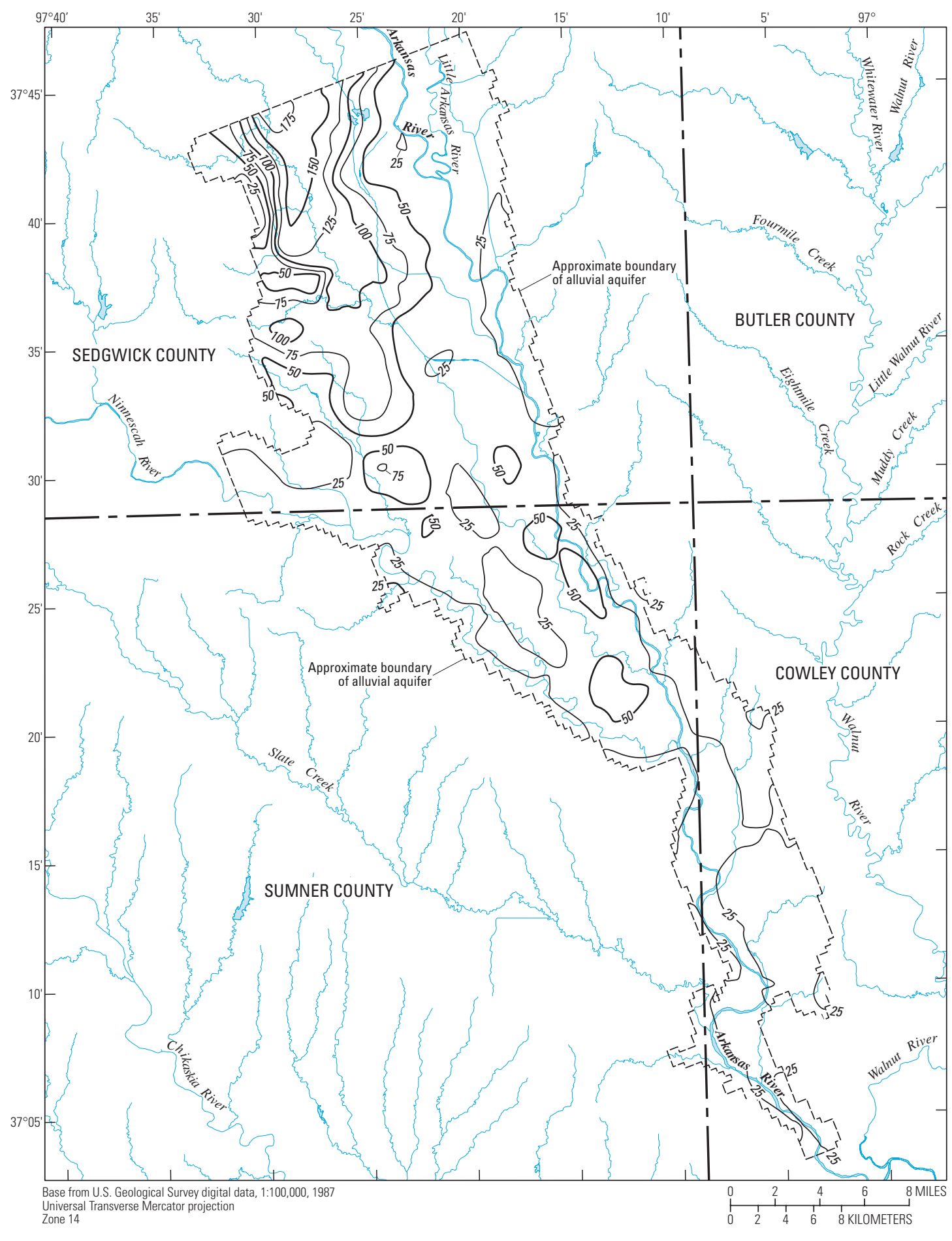

Horizontal coordinate information is referenced to the North American Datum of 1983 (NAD 83)

EXPLANATION

-50- Line of equal saturated thickness - Interval 25 feet

Figure 32. (B) Simulated saturated thickness of alluvial aquifer in modeled area using no pumping. 


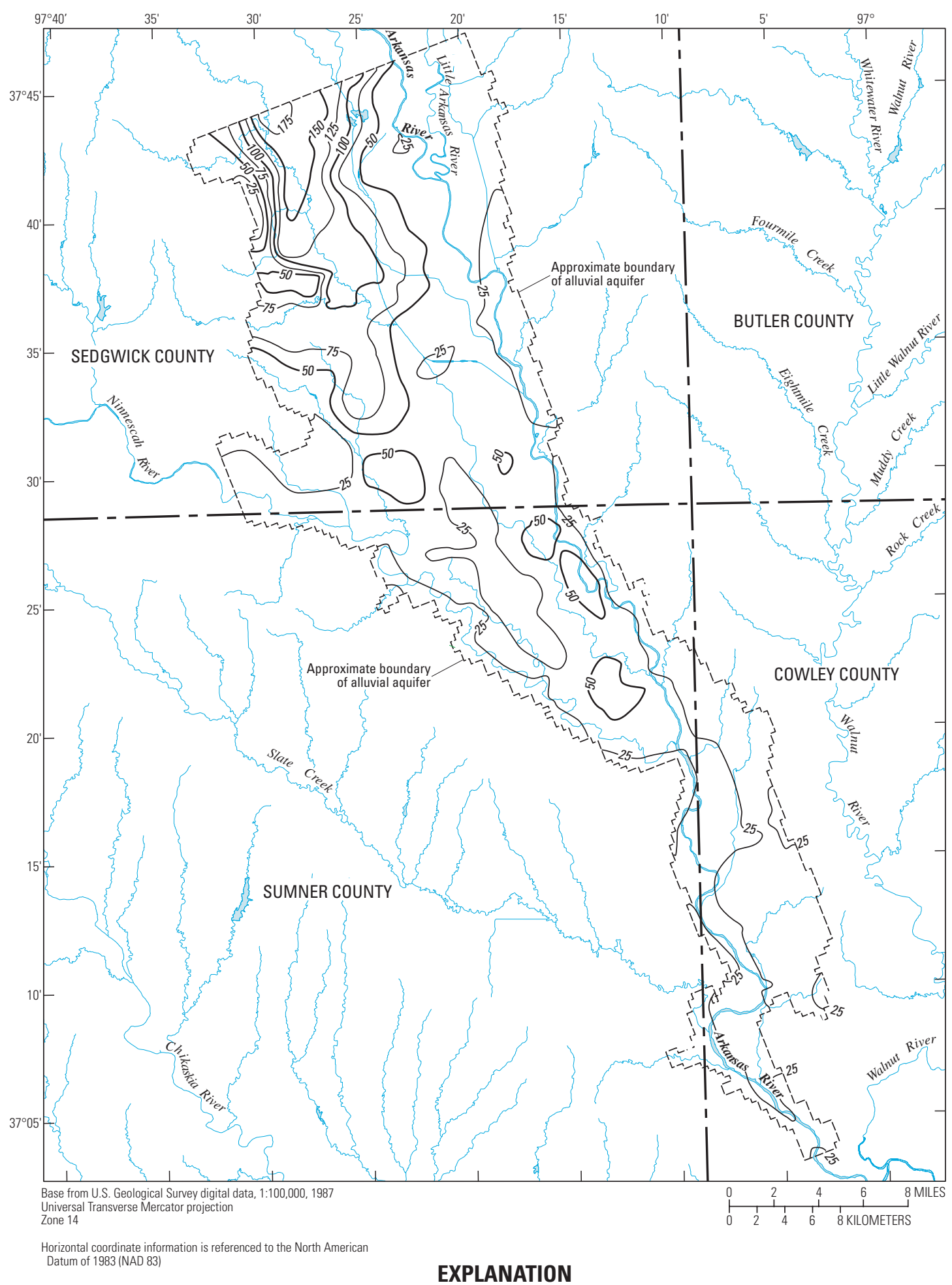

— 50 — Line of equal saturated thickness - Interval 25 feet

Figure 32. (C) Simulated saturated thickness of alluvial aquifer in modeled area using pumping at 2002 groundwater use. 


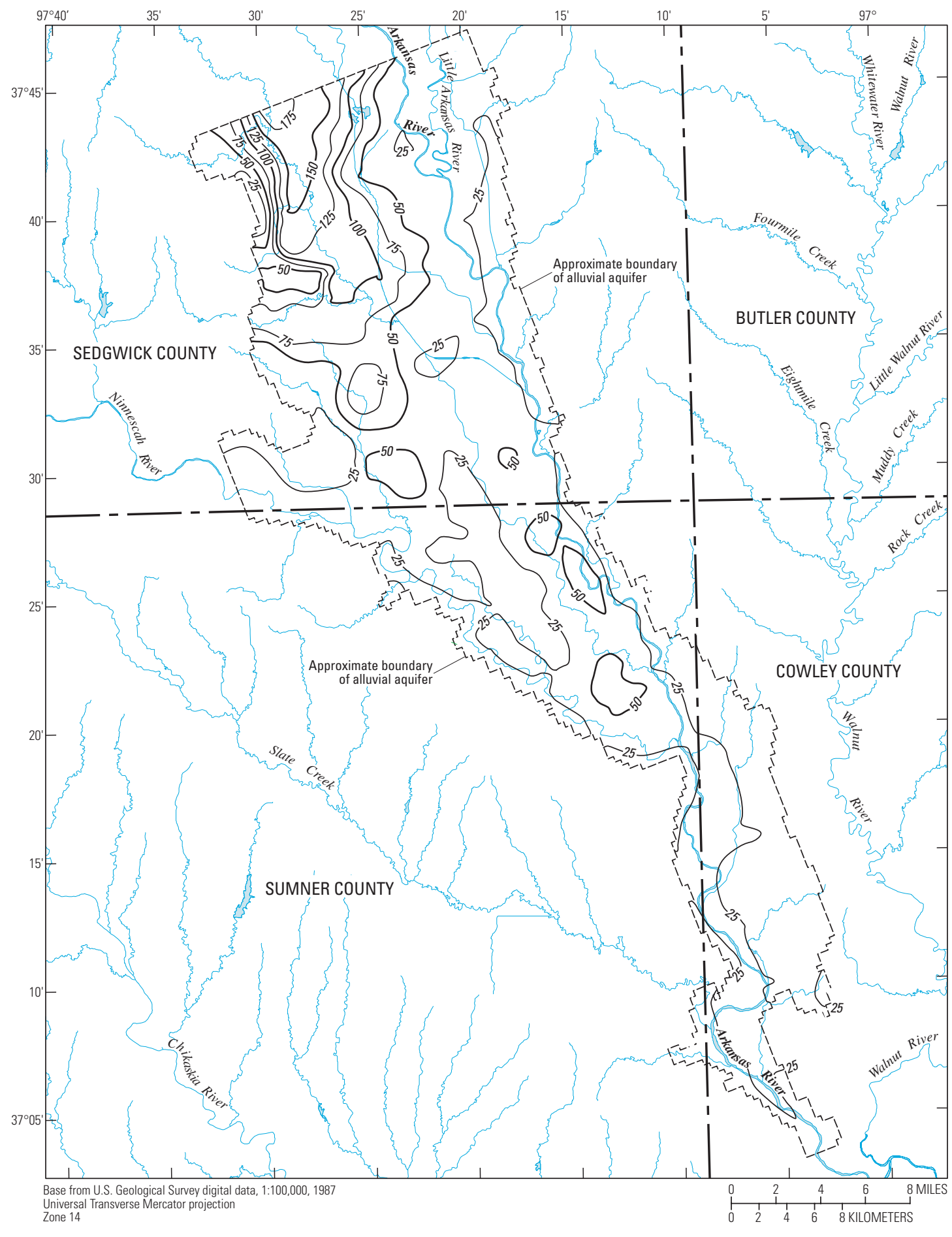

Horizontal coordinate information is referenced to the North American Datum of 1983 (NAD 83)

EXPLANATION

- 50 - Line of equal saturated thickness - Interval 25 feet

Figure 32. (D) Simulated saturated thickness of alluvial aquifer in modeled area using pumping at current (2004) authorized ground-water use. 


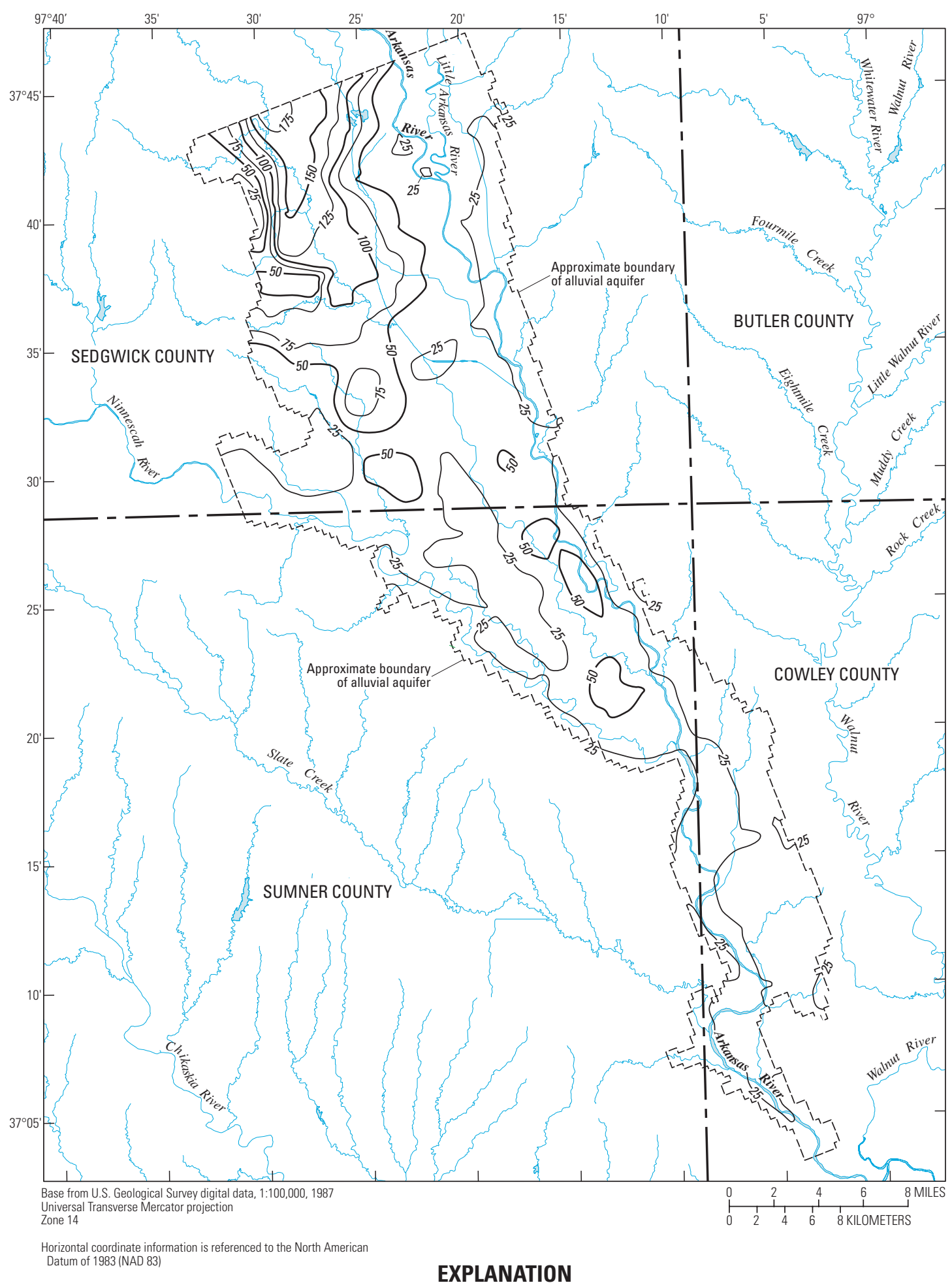

— 50 — Line of equal saturated thickness - Interval 25 feet

Figure 32. (E) Simulated saturated thickness of alluvial aquifer in modeled area using pumping at about 10 percent more than current (2004) authorized ground-water use. 


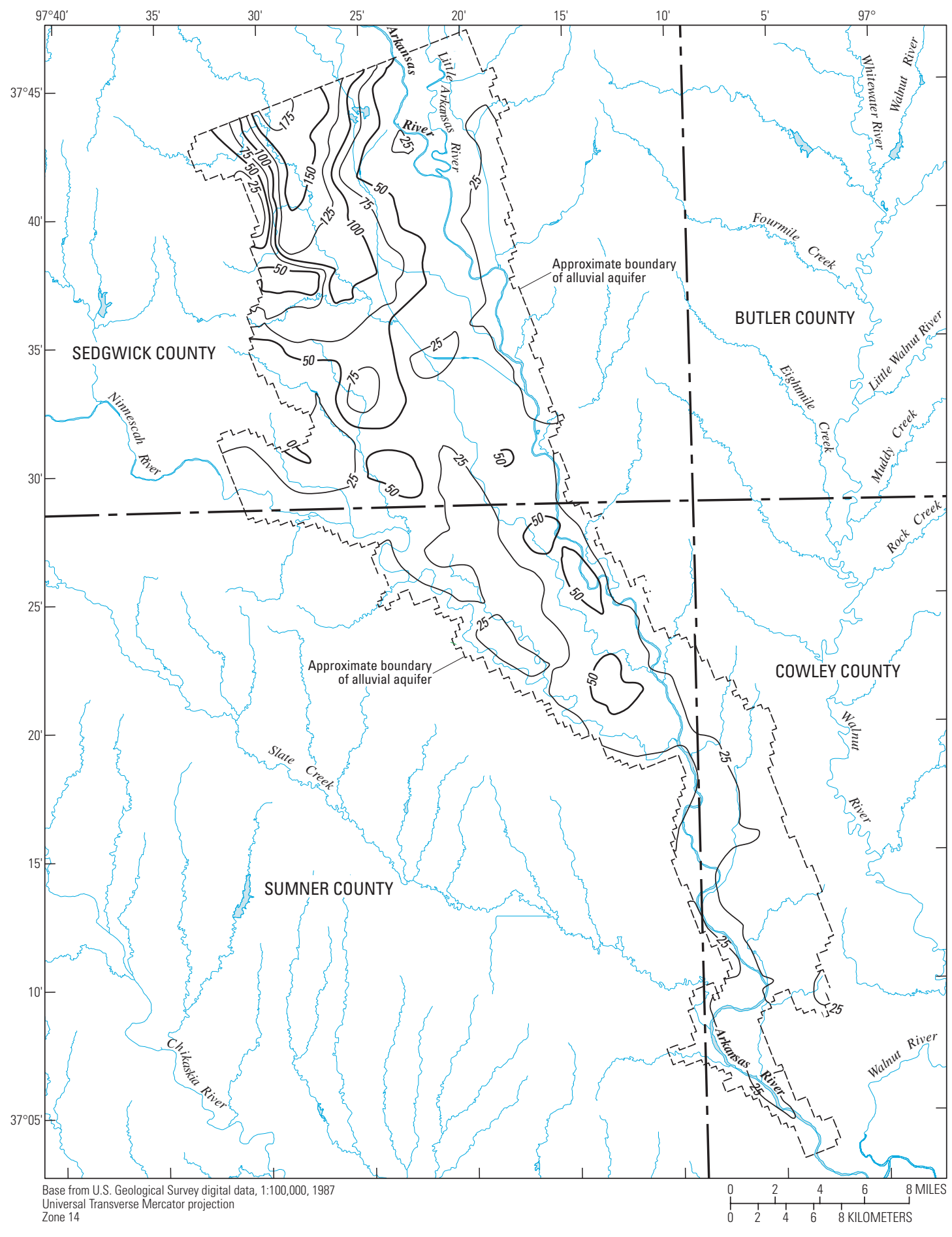

Horizontal coordinate information is referenced to the North American Datum of 1983 (NAD 83)

EXPLANATION

- 50 - Line of equal saturated thickness - Interval 25 feet

Figure 32. (F) Simulated saturated thickness of alluvial aquifer in modeled area using pumping at about 25 percent more than current (2004) authorized ground-water use. 


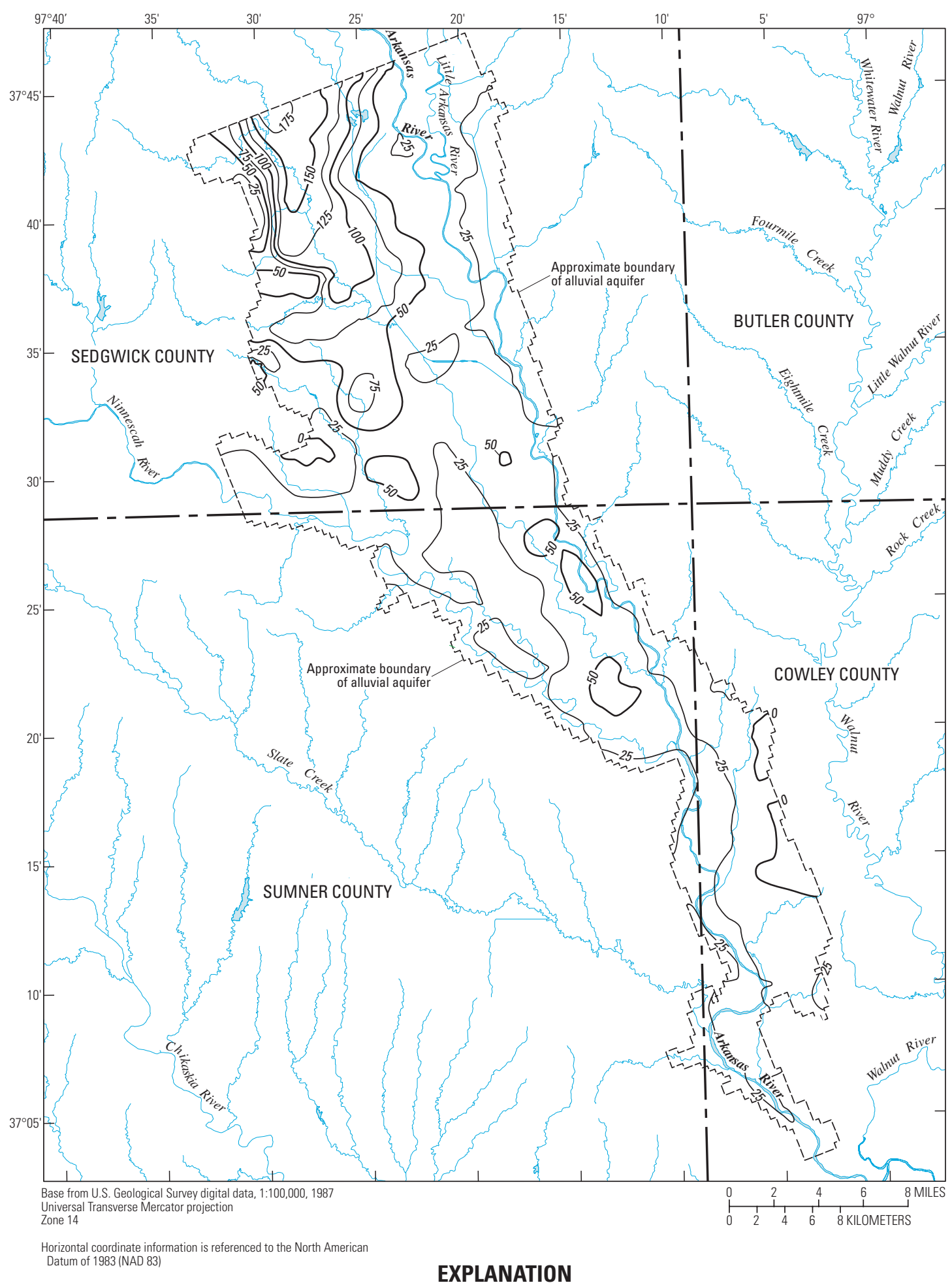

— 50 — Line of equal saturated thickness - Interval 25 feet

Figure 32. (G) Simulated saturated thickness of alluvial aquifer in modeled area using pumping at about 50 percent more than current (2004) authorized ground-water use. 


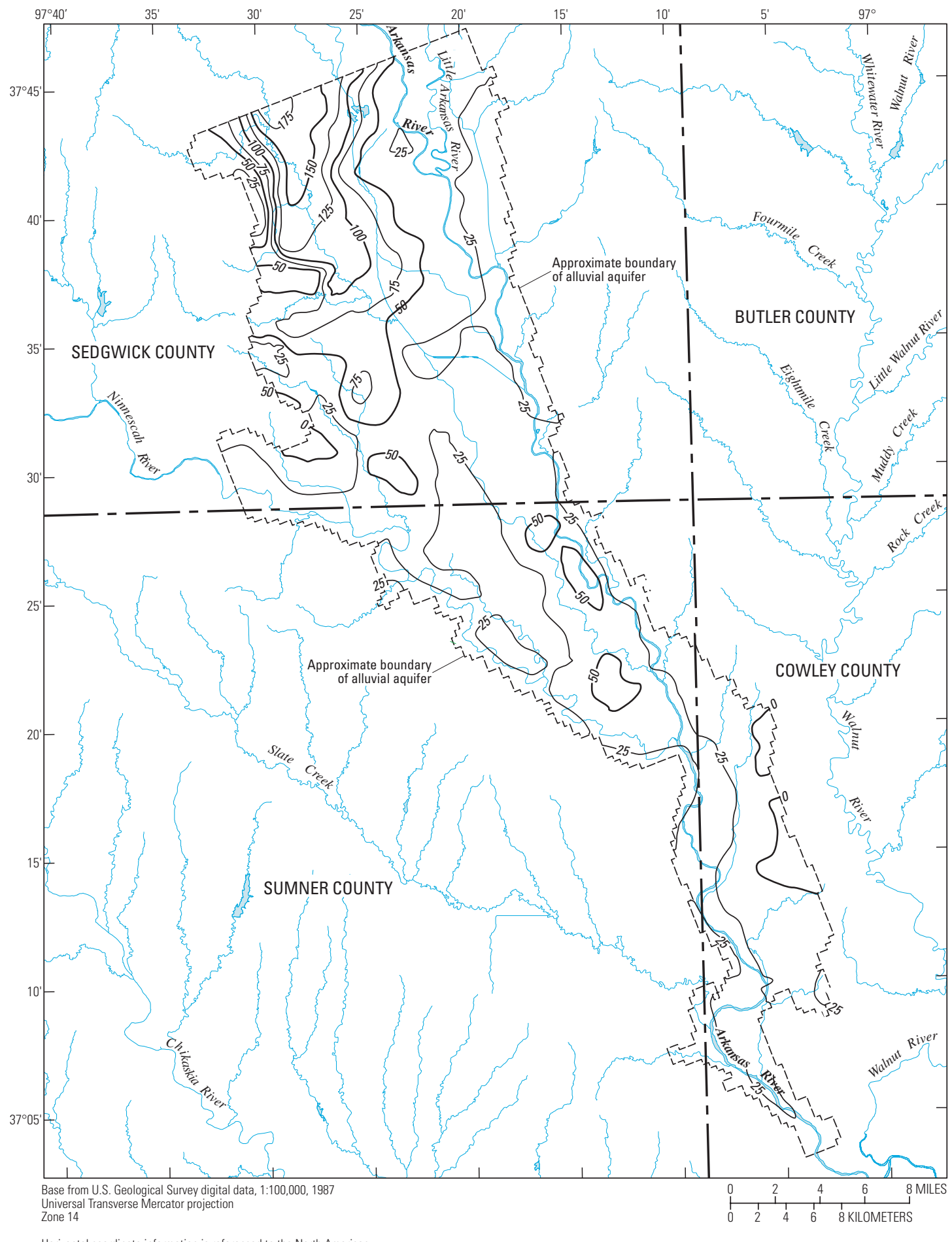

Horizontal coordinate information is referenced to the North American Datum of 1983 (NAD 83)

EXPLANATION

- 50 - Line of equal saturated thickness - Interval 25 feet

Figure 32. (H) Simulated saturated thickness of alluvial aquifer in modeled area using pumping at about 75 percent more than current (2004) authorized ground-water use. 


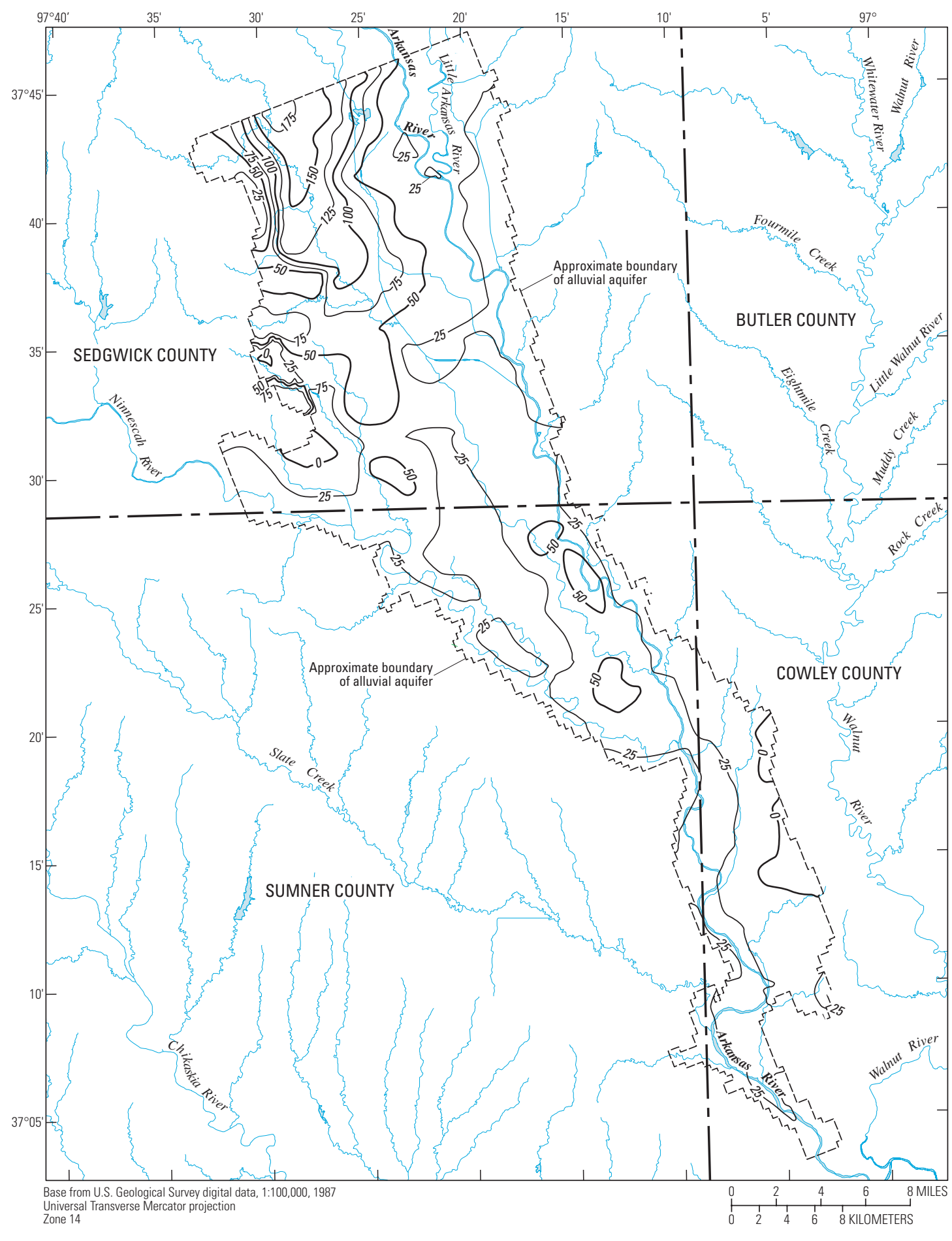

Horizontal coordinate information is referenced to the North American Datum of 1983 (NAD 83)

EXPLANATION

— 50 - Line of equal saturated thickness - Interval 25 feet

Figure 32. (I) Simulated saturated thickness of alluvial aquifer in modeled area using pumping at about 100 percent more than current (2004) authorized ground-water use. 


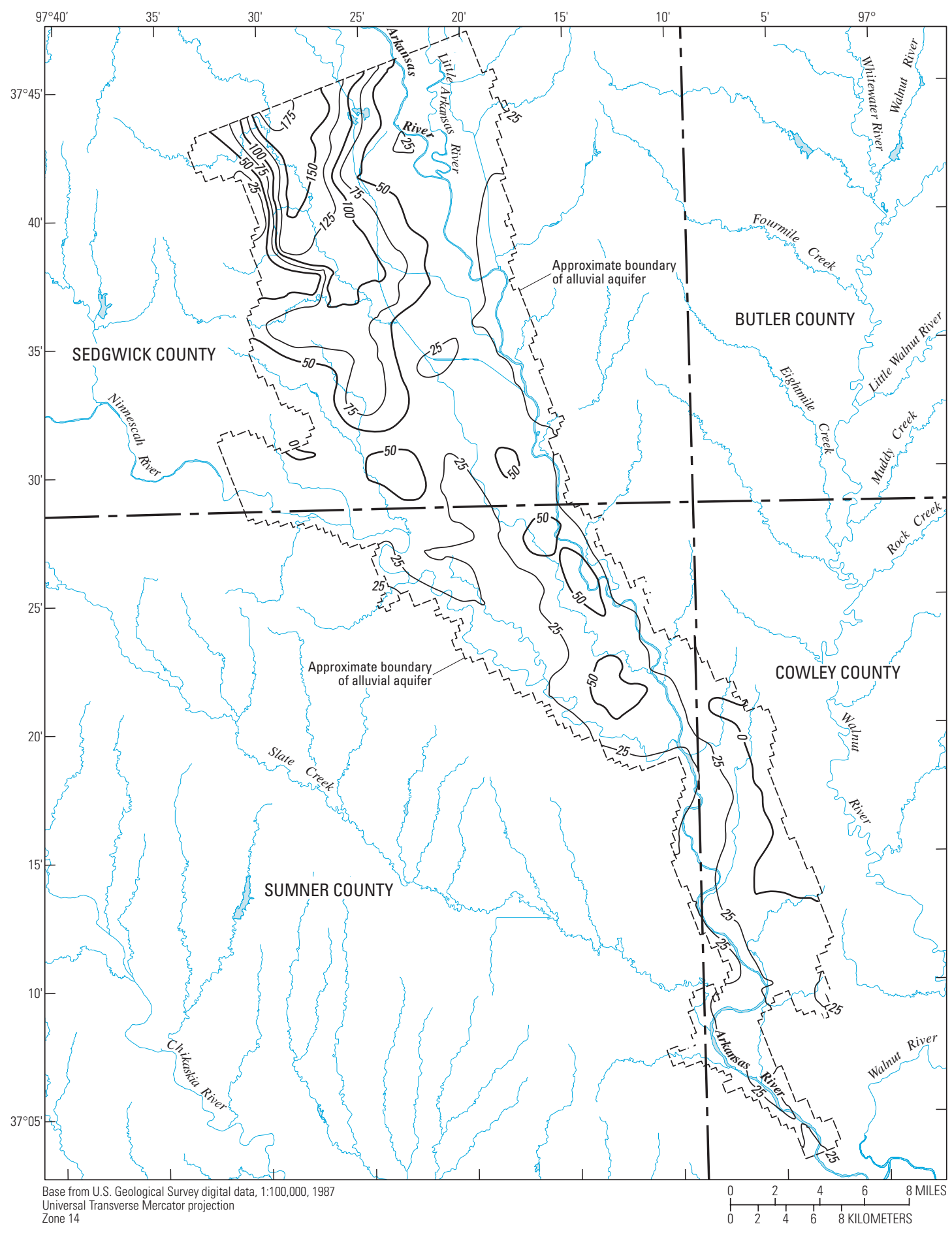

Horizontal coordinate information is referenced to the North American Datum of 1983 (NAD 83)

EXPLANATION

- 50 - Line of equal saturated thickness - Interval 25 feet

Figure 32. (J) Simulated saturated thickness of alluvial aquifer in modeled area using pumping at Hansen (1991) recharge rates in each model cell. 
Table 10. Estimated recharge rates in upland contributing-drainage areas, Butler, Harvey, Marion, Sedgwick, and Sumner Counties, south-central Kansas.

$\left[\mathrm{mi}^{2}\right.$, square miles; in/yr, inches per year]

\begin{tabular}{|c|c|c|c|c|c|}
\hline $\begin{array}{c}\text { Streamflow-gaging station } \\
\text { (fig. 8) }\end{array}$ & $\begin{array}{l}\text { Drainage area } \\
\qquad\left(\mathrm{mi}^{2}\right)\end{array}$ & $\begin{array}{l}\text { Period of record } \\
\text { (water years) }\end{array}$ & $\begin{array}{l}\text { Antecedent } \\
\text { recession } \\
\text { (days) }\end{array}$ & $\begin{array}{l}\text { Recession } \\
\text { index } \\
\text { (days/log } \\
\text { flow) }\end{array}$ & $\begin{array}{c}\text { Recharge } \\
\text { rate } \\
\text { (in } / y r)\end{array}$ \\
\hline \multirow{2}{*}{$\begin{array}{l}\text { Slate Creek at Wellington } \\
\text { (station } 07145700 \text { ) }\end{array}$} & 154 & 1980-99 & $3-6$ & $50-500$ & 1.2 \\
\hline & & $\begin{array}{c}1970-2001 \\
\text { (all available } \\
\text { record) }\end{array}$ & $3-6$ & $50-500$ & 1.0 \\
\hline \multirow{2}{*}{$\begin{array}{l}\text { Whitewater River at Towanda } \\
\text { (station 07147070) }\end{array}$} & 426 & 1980-99 & $4-6$ & $50-500$ & 1.9 \\
\hline & & $\begin{array}{c}\text { 1962-2001 } \\
\text { (all available } \\
\text { record) }\end{array}$ & $4-6$ & $50-500$ & 1.6 \\
\hline
\end{tabular}

\section{Recharge Outside the Arkansas River Alluvial Aquifer}

The computer program RORA (Rutledge, 1998, 2000) estimates base flow of streams and ground-water recharge using the recession-curve-displacement method and streamflow hydrographs. The method is based on the change in total potential ground-water discharge that is caused by each recharge event. The method is applied to a long period of record of daily mean streamflow (at least several years) and gives an estimate of the mean rate of ground-water recharge to the aquifer.

RORA was used in evaluating data from two streamflowgaging stations-Slate Creek at Wellington (station 07145700, 154- $\mathrm{mi}^{2}$ drainage area) and Whitewater River at Towanda (station $07147070,426-\mathrm{mi}^{2}$ drainage area) (fig. 2). Varying values of antecedent recession index and recession index were used in the RORA model. The results in table 10 are average recharge values obtained by varying the antecedent recession (in days) and the recession index (days/log flow) for two different time periods for each site. Recharge rates for each site and time period using different values noted for antecedent recession and recession index did not differ appreciably from the site and period-of-record average recharge rates. Rutledge (2000) also found that recharge arates from RORA tended to vary more using different periods of record than from differences in antecedent recession and recession index values within reasonable ranges.

Results of hydrograph separation analysis are estimates of aquifer discharge to streams and, barring factors such as pumpage, boundary flows, or major ground- or surface-water diversions, are used frequently as estimates of recharge (Rutledge, 2000). Because these values are averages across the respective drainage basins, areas of lower permeable soils (fig. 5) would be expected to have smaller recharge rates, and areas with more permeable soils would be expected to have larger recharge rates than these averages.

\section{Summary}

Large parts of the lower Arkansas, Ninnescah, and Walnut River Basins in south-central Kansas-an area that includes Wichita, the largest city in Kansas-are experiencing rapid population growth and, consequently, increasing demands on surface- and ground-water resources. The quantity and quality of water available in the lower Arkansas, Ninnescah, and Walnut River Basins in Butler, Cowley, Sedgwick, and Sumner Counties are crucial as population and water use continue to increase in the region. Average reported ground-water withdrawal from the Arkansas River alluvial aquifer in the modeled area from 1998-2001 was $56 \mathrm{ft}^{3} / \mathrm{s}$, whereas authorized water use was $106 \mathrm{ft}^{3} / \mathrm{s}$ as of 2004 .

A steady-state model was constructed to simulate flow in the Arkansas River alluvial aquifer between Wichita and Arkansas City. Calibration was achieved using March 2001 measured water levels and streamflow gain using long-term streamflow records. Average recharge was $5.4 \mathrm{in} / \mathrm{yr}$, and average aquifer hydraulic conductivity was about $500 \mathrm{ft} / \mathrm{d}$. Well pumpage (average of reported 1998-2001 use) was $56 \mathrm{ft}^{3} / \mathrm{s}$, and net aquifer to streamflow gain computed by hydrograph separation was $157 \mathrm{ft}^{3} / \mathrm{s}$.

Nine hypothetical simulations were conducted with ground-water pumpage varying from zero to almost double authorized pumpage $\left(206 \mathrm{ft}^{3} / \mathrm{s}\right)$. Net remaining aquifer thickness declined noticeably for the largest simulated pumpage increases in comparison to 1998-2001 average pumping, and 
the net aquifer flow to the Arkansas River declined to near zero. Simulated aquifer thickness decreases were more pronounced in areas where pumpage (average 1998-2001) was greatest.

\section{References Cited}

Aber, J.S., 1993, Geologic map of Butler County, Kansas: Kansas Geological Survey Map Series M-30, scale 1:50,000, 1 sheet.

Bauder, Troy, 2000, Understanding irrigation water quality: Agronomy News, March 2000, available on World Wide Web, accessed May 12, 2004, at URL http://www.colostate.edu/Depts/Soil/Crop/extension/ Newsletters/2000/Salinity/pg5.html

Bayne, C.K., 1962, Geology and ground-water resources of Cowley County, Kansas: Kansas Geological Survey Bulletin $158,219 \mathrm{p}$.

Bevans, H.E., 1988, Water supply and demand in Sedgwick County, Kansas: U.S. Geological Survey Open-File Report $88-711,2$ p.

Bevans, H.E., 1989, Water resources of Sedgwick County, Kansas: U.S. Geological Survey Water-Resources Investigations Report 88-4225, $119 \mathrm{p}$.

Brady, N.C., 1974, The nature and properties of soil (8th ed.): New York, Macmillan Publishing Co., Inc., 639 p.

Diaz, A.M., 1962, Quality of water investigation in the Walnut River Basin: Kansas Water News, v. 5, no. 3, p. 6-7.

Diaz, A.M., 1965, Cooperative water-quality investigation, South Fork Ninnescah Basin: Kansas Water News, v. 8, no. 3, p. 3-4.

Dugan, J.T., and Peckenpaugh, J.M., 1985, Effects of climate, vegetation, and soils on consumptive water use and groundwater recharge to the Central Midwest regional aquifer system, mid-continent United States: U.S. Geological Survey Water-Resources Investigations Report 85-4236, 78 p.

Engineering Enterprises, Inc., 1982, South Wichita chloride study: Topeka, Interim Report, Phase I, for the Kansas Department of Health and Environment, 62 p.

Fader, S.W., and Morton, R.B., 1975, Ground water in the Middle Arkansas River Basin, Kansas and Oklahoma: U.S. Geological Survey Open-File Report 75-367, 44 p.

Fenwick, R.W., and Ratcliff, I.W., Jr., 1979, Soil survey of Sumner County, Kansas: U.S. Department of Agriculture, 110 p., 88 plates.

Fishman, M.J., and Friedman, L.C., eds., 1989, Methods for determination of inorganic substances in water and fluvial sediments: U.S. Geological Survey Techniques of WaterResources Investigations, book 5, chap. A1, 545 p.

Frye, J.C., and Leonard, A.B., 1952, Pleistocene geology of Kansas: Kansas Geological Survey Bulletin 99, 230 p.

Gogel, Tony, 1981, Discharge of saltwater from Permian rocks to major stream-aquifer systems in central Kansas: Kansas Geological Survey Chemical Quality Series 9, 60 p.
Hammond, E.H., 1964, Classes of land-surface form in the forty-eight States, U.S.A.: Annuals of the Association of American Geographers, v. 54, no. 1.

Hansen, C.V., 1991, Estimates of freshwater storage and potential natural recharge for principal aquifers in Kansas: U.S. Geological Survey Water-Resources Investigations Report 87-4230, 100 p.

Hansen, C.V., and Aucott, W.R., 2004, Status of ground-water levels and storage volume in the Equus Beds aquifer near Wichita, Kansas, January 2000-January 2003: U.S. Geological Survey Water-Resources Investigations Report 03-4298, $36 \mathrm{p}$.

Hart, R.J., and Spruill, T.B., 1988, Description and hydrologic evaluation of nine hazardous-waste sites in Kansas, 1984-86: U.S. Geological Survey Water-Resources Investigations Report 88-4015, 73 p.

Heath, R.C., 1987, Basic ground-water hydrology: U.S. Geological Survey Water-Supply Paper 2220, 84 p.

Hem, J.D., 1992, Study and interpretation of the chemical characteristics of natural water (3d ed.): U.S. Geological Survey Water-Supply Paper 2254, $263 \mathrm{p}$.

High Plains Regional Climate Center, 2003, Historical data summaries-Kansas: Lincoln, University of Nebraska, information available on the World Wide Web, accessed August 19, 2003, at URL http://www.hprcc.unl.edu/ products/historical.htm

Horsch, M.L., 1980, Soil survey of Cowley County, Kansas: U.S. Department of Agriculture, 123 p., 88 plates.

Institute for Public Policy and Business Research, 2002, Kansas county level data: Lawrence, Kansas, University of Kansas, information available on the World Wide Web, accessed July 28, 2003, at URL http://www.ku.edu/pri/ksdata/ county.shtml

Institute for Public Policy and Business Research, 2003, Population, section 16, in Kansas statistical abstract 2001: Lawrence, Kansas, University of Kansas, information available on the World Wide Web, accessed August 6, 2003, at URL http://www.ku.edu/pri/ksdata/ksah/ksa34.sthml

Kansas Applied Remote Sensing Program, 1990, Kansas land cover mapping project—land cover for Sedgwick, Butler, Sumner, and Cowley Counties, Kansas: Lawrence, Kansas, Data Access and Support Center, information available on the World Wide Web, accessed September 15, 2003, at URL http://gisdasc.kgs.ukans.edu/kanview/landcover/html/ Butler.html http://gisdasc.kgs.ukans.edu/kanview/landcover/html/ Cowley.html http://gisdasc.kgs.ukans.edu/kanview/landcover/html/ Sedgwick.html http://gisdasc.kgs.ukans.edu/kanview/landcover/html/ Sumner.html

Kansas Geological Survey, 1964, Geologic map of Kansas: Kansas Geological Survey Map Series M-1, 1 sheet, scale 1:1,000,000. 
Kansas Geological Survey, 2003, Oil and gas production, by county: Information available on the World Wide Web, accessed December 24, 2002, at URL http://www.kgs.ku.edu/PRS/petro/interactive.html

Kansas State University, 2003, Precipitation summaryWeather Data Library: Manhattan, Kansas, Research and Extension, information available on the World Wide Web, accessed August 26, 2003, at URL http://www.oznet.ksu.edu/wdl/wdl/pmaps.htm

Kansas Water Authority, 1998, Kansas water plan-2010 objectives: Topeka, Kansas, information available on the World Wide Web, accessed September 9, 2003, at URL http://www.kwo.org/KWP/2010_objectives.htm

Kansas Water Office, 2002, The Kansas water plan-fiscal year 2004 update, approved by the Kansas Water Authority, July 11, 2002: Topeka, Kansas, information available on the World Wide Web, accessed September 9, 2003, at URL http://www.kwo.org/KWP/2004_kwp.htm

Lane, C.W., and Miller, D.E., 1965a, Geohydrology of Sedgwick County, Kansas: Kansas Geological Survey Bulletin 176, $100 \mathrm{p}$.

Lane, C.W., and Miller, D.E., 1965b, Logs of wells and test holes in Sedgwick County, Kansas: Kansas Geological Survey Special Distribution Publication 22, 175 p.

Lane, C.W., Reavis, E.L., and Stramel, G.J., 1962, Emergency water supplies in the Wichita area, Kansas: U.S. Geological Survey Hydrologic Investigations Atlas HA-58, scale 1:250,000, 1 sheet.

Lawrence, R.E., and Hess, R.H., 1963, Wichita's past, present, and future water supply: Journal of the American Water Works Association, v. 55, no. 8, p. 1081-1092.

Leonard, R.B., and Kleinschmidt, M.K., 1976, Saline water in the Little Arkansas River basin area, south-central Kansas: Kansas Geological Survey Chemical Quality Series 3, 24 p.

Lohman, S.W., 1979, Ground-water hydraulics: U.S. Geological Survey Professional Paper 708, 70 p., 9 pl.

McDonald, M.G., and Harbaugh, A.W., 1988, A modular threedimensional finite-difference ground-water flow model: U.S. Geological Survey Techniques of Water-Resources Investigations, book 6, chap. A1, variously paginated.

Meinzer, O.E., 1914, Preliminary report on ground water for irrigation in the vicinity of Wichita, Kansas: U.S. Geological Survey Water-Supply Paper 345-A, p. 1-9.

Myers, N.C., Hargadine, G.D., and Gillespie, J.B., 1996, Hydrologic and chemical interaction of the Arkansas River and the Equus Beds aquifer between Hutchinson and Wichita, south-central Kansas: U.S. Geological Survey WaterResources Investigations Report 95-4191, 100 p.

Myers, N.C., Heck, B.A., and Hargadine, D.A., 1993, Hydrogeology and ground-water-quality conditions at the Sumner County Landfill, south-central Kansas, 1989-90: U.S. Geological Survey Water-Resources Investigations Report 92-4177, 52 p.

Parker, H.N., 1911, Quality of the water supplies of Kansas: U.S. Geological Survey Water-Supply Paper 273, 375 p.
Penner, H.L., Ekart, S.C., Ewing, D.A., Schmidt, Gordon, and Smith, Jimmie, 1975, Soil survey of Butler County: U.S. Department of Agriculture, 60 p., 76 plates.

Penner, H.L., and Wehmueller, W.A., 1979, Soil survey of Sedgwick County, Kansas: U.S. Department of Agriculture, 126 p., 76 plates.

Perry, C.A., Wolock, D.M., and Artman, J.C., 2004, Estimates of flow duration, mean flow, and peak-discharge frequency values for Kansas stream locations: U.S. Geological Survey Scientific Investigations Report 2004-5033, 651 p.

Petri, L.R., Lane, C.W., and Furness, L.W., 1964, Water resources of the Wichita area, Kansas: U.S. Geological Survey Water-Supply Paper 1499-I, 69 p.

Putnam, J.E., and Schneider, D.R., 2004, Water resources data, Kansas, water year 2003: U.S. Geological Survey WaterData Report KS-03-1, 641 p.

Reed, T.B., and Burnett, R.D., 1985, Compilation and analyses of aquifer performance tests in eastern Kansas: U.S. Geological Survey Open-File Report 85-200, 125 p.

Richards, D.B., and Dunaway, T.W., 1972, Geohydrologic data for numerical modeling of ground-water withdrawal in the Little Arkansas River basin area, south-central Kansas: Lawrence, Kansas, U.S. Geological Survey open-file report, $426 \mathrm{p}$.

Rutledge, A.T., 1998, Computer programs for describing the recession of ground-water discharge and for estimating mean ground-water recharge and discharge from streamflow records-update: U.S. Geological Survey Water-Resources Investigations Report 98-4148, 43 p.

Rutledge, A.T., 2000, Considerations for use of the RORA program to estimate ground-water recharge from streamflow records: U.S. Geological Survey Open-File Report 00-156, $44 \mathrm{p}$.

Schoewe, W.H., 1949, The geography of Kansas, part IIphysical geography: Transactions of the Kansas Academy of Science, v. 52, no. 3, p. 261-333.

Sophocleus, M.A., 1983, Water quality modeling of the Equus Beds aquifer in south-central Kansas: Kansas Geological Survey Open-File Report 83-1, 75 p.

Sophocleous, M.A., and Perry, C.A., 1985, Experimental studies of natural groundwater recharge dynamics - the analysis of observed recharge: Journal of Hydrology, v. 81, p. 297-332.

Spinazola, J.M., Gillespie, J.B., and Hart, R.J., 1985, Groundwater flow and solute transport in the Equus beds area, southcentral Kansas, 1940-79: U.S. Geological Survey WaterResources Investigations Report 85-4336, 68 p.

Spruill, T.B., 1988, Use of total organic carbon as an indicator of contamination from an oil refinery, south-central Kansas: Ground Water Monitoring Review, Summer 1988, p. 76-82. Spruill, T.B., 1990, Preliminary evaluation of the effects of an abandoned oil refinery on chemical quality of water in the Arkansas River Valley, Arkansas City, Kansas, 1985-86: U.S. Geological Survey Water-Resources Investigations Report 89-4190, 53 p. 


\section{Characterization and Simulation of Flow in the Lower Arkansas River Alluvial Aquifer, South-Central Kansas}

Stramel, 1956, Progress report on the ground-water hydrology of the Equus beds area, Kansas: Kansas Geological Survey Bulletin 119, part 1, 59 p.

U.S. Census Bureau, 1995, Kansas, population of counties by decennial census - 1900 to 1990: Information available on the World Wide Web, accessed July 28, 2003, at URL http://www.census.gov/population/cencounts/ks190090.txt

U.S. Department of Agriculture, 1996, Detailed soils, 1:24,000 scale: Salina, Kansas, Natural Resources Conservation Service, digital data.

U.S. Environmental Protection Agency, 2003, National drinking water standards: Office of Water, EPA-816-F-03-016, information available on the World Wide Web, accessed December 23, 2003, at URL http://www.epa.gov/ safewater/mcl.html\#sec

U.S. Geological Survey, 2003, Water use in the United States by county for 1990, 1995, and 2000: Information available on the World Wide Web, accessed July 24, 2003, at URL http://water.usgs.gov/watuse/

U.S. Soil Conservation Service, 1967, Distribution of principal kinds of soils - orders, suborders, and great groups, in The national atlas of the United States of America, 1970: Department of the Interior, U.S. Geological Survey, p. 85-88.
Walters, K.L., 1961, Geology and ground-water resources of Sumner County, Kansas: Kansas Geological Survey Bulletin $151,198 \mathrm{p}$.

Wilde, F.D., and Radtke, D.B., eds., 1998, National field manual for the collection of water-quality data-field measurements: U.S. Geological Survey Techniques of Water-Resources Investigations, book 9, chap. A6, variously paged.

Wilde, F.D., Radtke, D.B., Gibs, Jacob, and Iwatsubo, R.T., eds., 1999, National field manual for the collection of waterquality data-collection of water samples: U.S. Geological Survey Techniques of Water-Resources Investigations, book 9, chap. A4, 156 p.

Williams, C.C., and Lohman, S.W., 1949, Geology and groundwater resources of a part of south-central Kansas, with special reference to the Wichita municipal water supply: Kansas Geological Survey Bulletin 79, 455 p.

Wood, W.W., 1976, Guidelines for collection and field analysis of ground-water samples for selected unstable constituents: U.S. Geological Survey Techniques of Water-Resources Investigations, book 2, chap. D2, $24 \mathrm{p}$. 
Supplemental Information 
Table 11. Results of water-quality analyses of samples collected during August 2003 from ground- and surface-water sites in Cowley, Sedgwick, and Sumner Counties, southcentral Kansas.

[ $\mathrm{ft}^{3} / \mathrm{s}$, cubic feet per second; $\mu \mathrm{S} / \mathrm{cm}$, microsiemens per centimeter at 25 degrees Celsius; ${ }^{\circ} \mathrm{C}$, degrees Celsius; $\mathrm{NTU}$, nephelometric turbidity units; mg/L, milligrams per liter; $\mathrm{CaCO}{ }_{3}$, calcium carbonate; $\mu \mathrm{g} / \mathrm{L}$, micrograms per liter; -- not determined; <, less than; E, estimated]

\begin{tabular}{|c|c|c|c|c|c|c|c|c|c|c|c|c|c|}
\hline $\begin{array}{l}\text { Map } \\
\text { no. } \\
\text { (fig. } \\
12 \text { ) }\end{array}$ & Site number & Local well number or site name & $\begin{array}{c}\text { Date of } \\
\text { sample } \\
\text { (month/day/ } \\
\text { year) }\end{array}$ & $\begin{array}{l}\text { Time } \\
(24- \\
\text { hour) }\end{array}$ & $\begin{array}{c}\text { Dis- } \\
\text { charge, } \\
\text { instan- } \\
\text { taneous } \\
\left(\mathrm{ft}^{3} / \mathrm{s}\right)\end{array}$ & $\begin{array}{c}\text { Specific } \\
\text { conduct- } \\
\text { ance, } \\
\text { onsite } \\
(\mu \mathrm{S} / \mathrm{cm})\end{array}$ & $\begin{array}{c}\text { Specific } \\
\text { conduct- } \\
\text { ance, } \\
\text { laboratory } \\
(\mu \mathrm{S} / \mathrm{cm})\end{array}$ & $\begin{array}{c}\mathrm{pH}, \\
\text { onsite } \\
\text { (stan- } \\
\text { dard } \\
\text { units) }\end{array}$ & $\begin{array}{c}\mathrm{pH}, \\
\text { labor- } \\
\text { atory } \\
\text { (stan- } \\
\text { dard } \\
\text { units) }\end{array}$ & $\begin{array}{c}\text { Temper- } \\
\text { ature, } \\
\text { water } \\
\left({ }^{\circ} \mathrm{C}\right)\end{array}$ & $\begin{array}{c}\text { Turbidity, } \\
\text { onsite } \\
\text { (NTU) }\end{array}$ & $\begin{array}{c}\text { Dis- } \\
\text { solved } \\
\text { oxygen } \\
\text { (mg/L) }\end{array}$ & $\begin{array}{c}\text { Acid- } \\
\text { neutral- } \\
\text { izing } \\
\text { capacity } \\
(\mathrm{mg} / \mathrm{L} \text { as } \\
\left.\mathrm{CaCO}_{3}\right)\end{array}$ \\
\hline \multicolumn{14}{|c|}{ Ground-water sites } \\
\hline 1 & 370209097015601 & 35S-04E-06BDD01 & 08/11/03 & 1020 & -- & 1,090 & 1,050 & 6.7 & 7.2 & 14.6 & $<0.10$ & 0.88 & 370 \\
\hline 2 & 370236096575401 & 34S-04E-35CCD01 & $08 / 11 / 03$ & 1150 & -- & 492 & 471 & 6.9 & 7.4 & 18.5 & $<.10$ & 5.7 & 250 \\
\hline 3 & 370420097031101 & 34S-03E-26CDC01 & $08 / 14 / 03$ & 1100 & -- & 377 & 355 & 6.0 & 6.9 & 17.3 & $<.10$ & 8.1 & 72 \\
\hline 4 & 370923097013101 & 33S-04E-30AA01 & $08 / 11 / 03$ & 1410 & -- & 991 & 1,030 & 7.0 & 7.3 & 16.3 & $<.10$ & 4.2 & 340 \\
\hline 5 & 371140097064501 & 33S-03E-09BCC01 & $08 / 19 / 03$ & 1350 & -- & 444 & 436 & 6.3 & 7.2 & 15.8 & $<.10$ & .96 & 160 \\
\hline 6 & 371257097050801 & 32S-03E-34DCC01 & 08/19/03 & 1450 & -- & 803 & 792 & 6.8 & 7.4 & 15.7 & $<.10$ & 2.6 & 280 \\
\hline 7 & 371357097093101 & 32S-02E-25DC01 & 08/19/03 & 1145 & -- & 1,840 & 1,870 & 6.7 & 7.3 & 16.4 & $<.10$ & .05 & 330 \\
\hline 8 & 371534097063001 & 32S-03E-21B01 & $08 / 13 / 03$ & 0955 & -- & 968 & 932 & 6.7 & 7.2 & 16.0 & -- & 1.3 & 290 \\
\hline 9 & 371552097054001 & $32 \mathrm{~S}-03 \mathrm{E}-15 \mathrm{CBC} 01$ & 08/13/03 & 1115 & -- & 744 & 723 & 6.8 & 7.3 & 16.1 & $<.10$ & 5.0 & 270 \\
\hline 10 & 371625097091901 & $32 \mathrm{~S}-02 \mathrm{E}-13 \mathrm{ABA} 01$ & 08/13/03 & 1400 & -- & 666 & 634 & 7.2 & 7.5 & 17.0 & -- & .07 & 190 \\
\hline 11 & 371813097083101 & 32S-03E-06АВB01 & 08/13/03 & 1220 & -- & 701 & 672 & 6.8 & 7.3 & 15.6 & -- & 0.09 & 260 \\
\hline 12 & 371959097121901 & 31S-02E-21DDD01 & 08/11/03 & 1515 & -- & 841 & 803 & 7.1 & 7.6 & 16.5 & -- & 8.0 & 260 \\
\hline 13 & 372000097075601 & 31S-03E-20CCВ01 & 08/19/03 & 1015 & -- & 335 & 328 & 5.9 & 6.8 & 15.9 & $<.10$ & 2.3 & 46 \\
\hline 14 & 372033097105402 & 31S-02E-23BDB02 & 08/13/03 & 1420 & -- & 826 & 791 & 7.2 & 7.6 & 18.2 & -- & 7.6 & 280 \\
\hline 15 & 372048097135101 & $31 \mathrm{~S}-02 \mathrm{E}-20 \mathrm{ABB} 01$ & 08/18/03 & 1335 & -- & 853 & 841 & 6.8 & 7.3 & 17.0 & -- & .05 & 330 \\
\hline 16 & 372135097154801 & 31S-01E-13ABD01 & 08/13/03 & 1500 & -- & 667 & 637 & 7.3 & 7.4 & 19.1 & -- & 9.1 & 290 \\
\hline 17 & 372225097090701 & 31S-02E-12AAC01 & $08 / 14 / 03$ & 1300 & -- & 854 & -- & 6.7 & -- & 16.5 & $<.10$ & 7.5 & -- \\
\hline 18 & 372245097133701 & 31S-02E-05DDC01 & 08/18/03 & 1445 & -- & 483 & 474 & 7.1 & 7.8 & 17.1 & -- & 6.8 & 210 \\
\hline 19 & 372335097160301 & 30S-01E-36CDD01 & 08/18/03 & 1045 & -- & 608 & 598 & 6.5 & 7.2 & 15.1 & -- & 6.0 & 160 \\
\hline 20 & 372349097111201 & 30S-02E-34DAA01 & $08 / 18 / 03$ & 1155 & -- & 494 & 486 & 6.6 & 7.3 & 16.2 & -- & 8.1 & 200 \\
\hline
\end{tabular}


Table 11. Results of water-quality analyses of samples collected during August 2003 from ground- and surface-water sites in Cowley, Sedgwick, and Sumner Counties, southcentral Kansas.-Continued

[ $\mathrm{ft}^{3} / \mathrm{s}$, cubic feet per second; $\mu \mathrm{S} / \mathrm{cm}$, microsiemens per centimeter at 25 degrees Celsius; ${ }^{\circ} \mathrm{C}$, degrees Celsius; $\mathrm{NTU}$, nephelometric turbidity units; mg/L, milligrams per liter; CaCO ${ }_{3}$, calcium carbonate; $\mu \mathrm{g} / \mathrm{L}$, micrograms per liter; -- not determined; <, less than; E, estimated]

\begin{tabular}{|c|c|c|c|c|c|c|c|c|c|c|c|c|c|}
\hline $\begin{array}{l}\text { Map } \\
\text { no. } \\
\text { (fig. } \\
12 \text { ) }\end{array}$ & Site number & Local well number or site name & $\begin{array}{c}\text { Date of } \\
\text { sample } \\
\text { (month/day/ } \\
\text { year) }\end{array}$ & $\begin{array}{l}\text { Time } \\
(24- \\
\text { hour })\end{array}$ & $\begin{array}{c}\text { Dis- } \\
\text { charge, } \\
\text { instan- } \\
\text { taneous } \\
\left(\mathrm{ft}^{3} / \mathrm{s}\right)\end{array}$ & $\begin{array}{c}\text { Specific } \\
\text { conduct- } \\
\text { ance, } \\
\text { onsite } \\
(\mu \mathrm{S} / \mathrm{cm})\end{array}$ & $\begin{array}{c}\text { Specific } \\
\text { conduct- } \\
\text { ance, } \\
\text { laboratory } \\
(\mu \mathrm{S} / \mathrm{cm})\end{array}$ & $\begin{array}{l}\text { pH, } \\
\text { onsite } \\
\text { (stan- } \\
\text { dard } \\
\text { units) }\end{array}$ & $\begin{array}{c}\mathrm{pH}, \\
\text { labor- } \\
\text { atory } \\
\text { (stan- } \\
\text { dard } \\
\text { units) }\end{array}$ & $\begin{array}{c}\text { Temper- } \\
\text { ature, } \\
\text { water } \\
\left({ }^{\circ} \mathrm{C}\right)\end{array}$ & $\begin{array}{c}\text { Turbidity, } \\
\text { onsite } \\
\text { (NTU) }\end{array}$ & $\begin{array}{c}\text { Dis- } \\
\text { solved } \\
\text { oxygen } \\
\text { (mg/L) }\end{array}$ & $\begin{array}{c}\text { Acid- } \\
\text { neutral- } \\
\text { izing } \\
\text { capacity } \\
\text { (mg/L as } \\
\mathrm{CaCO}_{3} \text { ) }\end{array}$ \\
\hline \multicolumn{14}{|c|}{ Ground-water sites-Continued } \\
\hline 21 & 372517097184001 & $30 \mathrm{~S}-01 \mathrm{E}-22 \mathrm{CCC} 01$ & 08/18/03 & 0940 & -- & 734 & 725 & 6.4 & 7.4 & 16.0 & -- & 4.9 & 170 \\
\hline 22 & 372755097231401 & 30S-01W-01CCB01 & 08/12/03 & 1540 & -- & 1,180 & 1,140 & 6.7 & 7.2 & 15.8 & $<10$ & .07 & 390 \\
\hline 23 & 373010097271701 & 29S-01W-29BAC01 & $08 / 12 / 03$ & 1010 & -- & 732 & 704 & 6.6 & 7.2 & 18.2 & $<.10$ & 4.6 & 250 \\
\hline 24 & 373024097211801 & 29S-01E-19DDC01 & $08 / 12 / 03$ & 1300 & -- & 554 & 553 & 6.7 & 7.2 & 15.7 & $<.10$ & 7.8 & 190 \\
\hline 25 & 373303097255701 & 29S-01W-04DCA01 & $08 / 12 / 03$ & 1120 & -- & 750 & 722 & 6.7 & 7.1 & 17.6 & $<.10$ & 2.6 & 270 \\
\hline 26 & 374101097191501 & 27S-01E-21DAC01 & 08/15/03 & 1335 & -- & 1,310 & 1,330 & 7.5 & 7.8 & 19.9 & .30 & 7.3 & 260 \\
\hline 27 & 374102097214301 & 27S-01E-19DBC01 & 08/15/03 & 1430 & -- & 1,260 & 1,260 & 7.6 & 7.8 & 19.3 & -- & 7.0 & 340 \\
\hline 28 & 374310097193301 & 27S-01E-09ABC01 & 08/20/03 & 0915 & -- & 1,140 & 1,140 & 6.9 & 7.3 & 19.7 & $<.10$ & 5.9 & 460 \\
\hline 29 & 374419097254201 & 26S-01W-33DDD01 & $08 / 15 / 03$ & 0925 & -- & 542 & 536 & 6.8 & 7.5 & 15.8 & $<.10$ & .15 & 170 \\
\hline 30 & 374447097213701 & 26-01E-31ACC01 & 08/15/03 & 1055 & -- & 1,460 & 1,490 & 6.8 & 7.5 & 16.4 & $<.10$ & .25 & 270 \\
\hline \multicolumn{14}{|c|}{ Surface-water sites } \\
\hline 31 & 07143375 & Arkansas River near Maize & 08/12/03 & 0930 & 51.2 & 2,430 & 2,370 & 8.2 & 8.2 & 23.2 & 11 & 10 & 130 \\
\hline 32 & 07144550 & Arkansas River at Derby & 08/12/03 & 1230 & 167 & 1,320 & 1,310 & 8.1 & 8.0 & 29.4 & 9.0 & 8.6 & 160 \\
\hline 33 & 07145500 & Ninnescah River near Peck & $08 / 12 / 03$ & 1400 & 45.1 & 1,340 & 1,290 & 8.5 & 8.3 & 30.5 & 7.7 & 9.8 & 150 \\
\hline 34 & 07146500 & Arkansas River at Arkansas City & 08/13/03 & 1145 & 386 & 1,610 & 1,490 & 9.2 & 9.0 & 26.1 & 33 & 15 & 160 \\
\hline 35 & 371004097085700 & Slate Creek (33S-02E-24ADD) & 08/11/03 & 1115 & 2.0 & 7,280 & 6,990 & 8.1 & 8.0 & 37.1 & 62 & 6.4 & 250 \\
\hline 36 & 371632097093600 & Arkansas River at Oxford & 08/11/03 & 1040 & 267 & 1,540 & 1,530 & 8.5 & 8.4 & 25.3 & 14 & 9.1 & 180 \\
\hline 37 & 371758097083400 & Sand quarry near Oxford & 08/13/03 & 1200 & -- & 700 & 524 & 6.9 & 8.0 & 26.9 & -- & 6.7 & 140 \\
\hline 38 & 371852097104200 & Ninnescah River (31S-02E-35ABB) & 08/11/03 & 1215 & 73.3 & 1,700 & 1,650 & 8.4 & 8.2 & 27.2 & 28 & 10 & 190 \\
\hline 39 & 372344097185400 & Oxbow lake near Belle Plaine & $08 / 19 / 03$ & 0850 & -- & 6,580 & 6,540 & 8.4 & 7.6 & 25.6 & 35 & 3.0 & 180 \\
\hline 40 & 372828097160000 & Sand quarry near Mulvane & $08 / 13 / 03$ & 0920 & -- & 602 & 567 & 8.3 & 8.1 & 20.2 & .60 & 8.8 & 140 \\
\hline
\end{tabular}


Table 11. Results of water-quality analyses of samples collected during August 2003 from ground- and surface-water sites in Cowley, Sedgwick, and Sumner Counties, southcentral Kansas.-Continued

$\mathrm{ft}^{3} / \mathrm{s}$, cubic feet per second; $\mu \mathrm{S} / \mathrm{cm}$, microsiemens per centimeter at 25 degrees Celsius; ${ }^{\circ} \mathrm{C}$, degrees Celsius; $\mathrm{NTU}$, nephelometric turbidity units; mg/L, milligrams per liter; CaCO ${ }_{3}$, calcium carbonate; $\mu \mathrm{g} / \mathrm{L}$, micrograms per liter; -- not determined; <, less than; E, estimated]

\begin{tabular}{|c|c|c|c|c|c|c|c|c|c|c|c|c|c|c|c|}
\hline $\begin{array}{l}\text { Map } \\
\text { no. } \\
\text { (fig. } \\
12 \text { ) }\end{array}$ & Site number & Local well number or site name & $\begin{array}{c}\text { Date of } \\
\text { sample } \\
\text { (month/day/ } \\
\text { year) }\end{array}$ & $\begin{array}{l}\text { Time } \\
(24- \\
\text { hour) }\end{array}$ & $\begin{array}{l}\text { Dis- } \\
\text { solved } \\
\text { solids } \\
\text { (mg/L) }\end{array}$ & $\begin{array}{l}\text { Cal- } \\
\text { cium } \\
\text { (mg/L) }\end{array}$ & $\begin{array}{l}\text { Mag- } \\
\text { nesium } \\
\text { (mg/L) }\end{array}$ & $\begin{array}{l}\text { Sodium } \\
\text { (mg/L) }\end{array}$ & $\begin{array}{l}\text { Potas- } \\
\text { sium } \\
\text { (mg/L) }\end{array}$ & $\begin{array}{l}\text { Sulfate } \\
(\mathrm{mg} / \mathrm{L})\end{array}$ & $\begin{array}{l}\text { Chlor- } \\
\text { ide } \\
\text { (mg/L) }\end{array}$ & $\begin{array}{l}\text { Fluo- } \\
\text { ride } \\
\text { (mg/L) }\end{array}$ & $\begin{array}{l}\text { Silica } \\
\text { (mg/L) }\end{array}$ & $\begin{array}{l}\text { Boron } \\
(\mu \mathrm{g} / \mathrm{L})\end{array}$ & $\begin{array}{l}\text { Iron } \\
(\mu \mathrm{g} / \mathrm{L})\end{array}$ \\
\hline \multicolumn{16}{|c|}{ Ground-water sites } \\
\hline 1 & 370209097015601 & 35S-04E 06BDD01 & $08 / 11 / 03$ & 1020 & 690 & 120 & 39 & 59 & 1.7 & 98 & 77 & 0.4 & 19 & 180 & E5 \\
\hline 2 & 370236096575401 & 34S-04E-35CCD01 & $08 / 11 / 03$ & 1150 & 300 & 78 & 10 & 13 & 2.3 & 16 & 5.2 & .3 & 18 & 70 & $<8$ \\
\hline 3 & 370420097031101 & 34S-03E-26CDC01 & $08 / 14 / 03$ & 1100 & 248 & 35 & 7.1 & 24 & 1.5 & 43 & 28 & $<.2$ & 24 & 30 & $<8$ \\
\hline 4 & 370923097013101 & 33S-04E-30AA01 & $08 / 11 / 03$ & 1410 & 665 & 95 & 15 & 130 & 2.1 & 110 & 80 & .3 & 18 & 160 & 38 \\
\hline 5 & 371140097064501 & 33S-03E-09BCC01 & 08/19/03 & 1350 & 283 & 51 & 11 & 29 & 2.2 & 38 & 13 & .3 & 24 & 60 & $<8$ \\
\hline 6 & 371257097050801 & 32S-03E-34DCC01 & $08 / 19 / 03$ & 1450 & 497 & 85 & 21 & 64 & 2.5 & 61 & 43 & .4 & 20 & 120 & $<8$ \\
\hline 7 & 371357097093101 & $32 \mathrm{~S}-02 \mathrm{E}-25 \mathrm{DC} 01$ & $08 / 19 / 03$ & 1145 & 1,100 & 180 & 40 & 150 & 3.2 & 48 & 380 & 6 & 17 & 100 & 1,540 \\
\hline 8 & 371534097063001 & 32S-03E-21B01 & 08/13/03 & 0955 & 623 & 120 & 16 & 83 & 2.5 & 81 & 29 & 6 & 19 & 70 & 9 \\
\hline 9 & 371552097054001 & $32 \mathrm{~S}-03 \mathrm{E}-15 \mathrm{CBC} 01$ & $08 / 13 / 03$ & 1115 & 489 & 72 & 19 & 63 & 1.8 & 72 & 27 & .4 & 22 & 90 & $<8$ \\
\hline 10 & 371625097091901 & $32 \mathrm{~S}-02 \mathrm{E}-13 \mathrm{ABA} 01$ & $08 / 13 / 03$ & 1400 & 390 & 59 & 10 & 70 & 3.4 & 43 & 69 & .5 & 16 & 70 & 260 \\
\hline 11 & 371813097083101 & 32S-03E-06АВB01 & $08 / 13 / 03$ & 1220 & 453 & 97 & 18 & 25 & 1.9 & 85 & 18 & .2 & 20 & 60 & $<8$ \\
\hline 12 & 371959097121901 & 31S-02E-21DDD01 & $08 / 11 / 03$ & 1515 & 593 & 130 & 22 & 32 & 2.6 & 180 & 12 & .5 & 20 & 100 & 280 \\
\hline 13 & 372000097075601 & 31S-03E-20CCВ01 & $08 / 19 / 03$ & 1015 & 216 & 27 & 8.1 & 20 & 1.7 & 20 & 39 & $<.2$ & 25 & 20 & $<8$ \\
\hline 14 & 372033097105402 & 31S-02E-23BDB02 & $08 / 13 / 03$ & 1420 & 557 & 120 & 19 & 37 & 2.7 & 140 & 17 & .7 & 17 & 90 & E7 \\
\hline 15 & 372048097135101 & 31S-02E-20ABB01 & $08 / 18 / 03$ & 1335 & 544 & 120 & 24 & 44 & 2.1 & 120 & 14 & 6 & 18 & 80 & 290 \\
\hline 16 & 372135097154801 & 31S-01E-13ABD01 & $08 / 13 / 03$ & 1500 & 423 & 97 & 17 & 19 & 1.8 & 46 & 13 & .3 & 21 & 80 & 30 \\
\hline 17 & 372225097090701 & 31S-02E-12AAC01 & $08 / 14 / 03$ & 1300 & -- & -- & -- & -- & -- & -- & -- & -- & -- & -- & -- \\
\hline 18 & 372245097133701 & 31S-02E-05DDC01 & 08/18/03 & 1445 & 296 & 89 & 5.9 & 9.4 & 5.4 & 17 & 7.2 & .3 & 18 & 40 & $<8$ \\
\hline 19 & 372335097160301 & 30S-01E-36CDD01 & $08 / 18 / 03$ & 1045 & 377 & 63 & 16 & 41 & 3.4 & 63 & 38 & .3 & 21 & 140 & 20 \\
\hline 20 & 372349097111201 & 30S-02E-34DAA01 & 08/18/03 & 1155 & 306 & 67 & 13 & 24 & 1.6 & 26 & 5.6 & .3 & 24 & 60 & $<8$ \\
\hline 21 & 372517097184001 & 30S-01E-22CCC01 & 08/18/03 & 0940 & 461 & 69 & 17 & 61 & 3.7 & 52 & 55 & .2 & 21 & 70 & $<8$ \\
\hline 22 & 372755097231401 & 30S-01W-01CCB01 & $08 / 12 / 03$ & 1540 & 834 & 160 & 32 & 58 & 3.0 & 210 & 48 & .3 & 19 & 50 & 2,020 \\
\hline 23 & 373010097271701 & 29S-01W-29BAC01 & $08 / 12 / 03$ & 1010 & 469 & 74 & 21 & 48 & 1.8 & 57 & 40 & .3 & 34 & 100 & $<8$ \\
\hline 24 & 373024097211801 & 29S-01E-19DDC01 & $08 / 12 / 03$ & 1300 & 352 & 51 & 11 & 45 & 1.9 & 30 & 21 & .3 & 24 & 80 & $<8$ \\
\hline 25 & 373303097255701 & 29S-01W-04DCA01 & $08 / 12 / 03$ & 1120 & 467 & 77 & 17 & 57 & 2.4 & 31 & 57 & .4 & 36 & 90 & E4 \\
\hline
\end{tabular}


Table 11. Results of water-quality analyses of samples collected during August 2003 from ground- and surface-water sites in Cowley, Sedgwick, and Sumner Counties, southcentral Kansas.-Continued

$\mathrm{ft}^{3} / \mathrm{s}$, cubic feet per second; $\mu \mathrm{S} / \mathrm{cm}$, microsiemens per centimeter at 25 degrees Celsius; ${ }^{\circ} \mathrm{C}$, degrees Celsius; NTU, nephelometric turbidity units; mg/L, milligrams per liter; CaCO 3 , calcium carbonate; $\mu \mathrm{g} / \mathrm{L}$, micrograms per liter; -- not determined; <, less than; E, estimated]

\begin{tabular}{|c|c|c|c|c|c|c|c|c|c|c|c|c|c|c|c|}
\hline $\begin{array}{l}\text { Map } \\
\text { no. } \\
\text { (fig. } \\
12 \text { ) }\end{array}$ & Site number & Local well number or site name & $\begin{array}{c}\text { Date of } \\
\text { sample } \\
\text { (month/day/ } \\
\text { year) }\end{array}$ & $\begin{array}{l}\text { Time } \\
(24- \\
\text { hour) }\end{array}$ & $\begin{array}{c}\text { Dis- } \\
\text { solved } \\
\text { solids } \\
\text { (mg/L) }\end{array}$ & $\begin{array}{l}\text { Cal- } \\
\text { cium } \\
\text { (mg/L) }\end{array}$ & $\begin{array}{c}\text { Mag- } \\
\text { nesium } \\
(\mathrm{mg} / \mathrm{L})\end{array}$ & $\begin{array}{c}\text { Sodium } \\
\text { (mg/L) }\end{array}$ & $\begin{array}{l}\text { Potas- } \\
\text { sium } \\
(\mathrm{mg} / \mathrm{L})\end{array}$ & $\begin{array}{l}\text { Sulfate } \\
(\mathrm{mg} / \mathrm{L})\end{array}$ & $\begin{array}{l}\text { Chlor- } \\
\text { ide } \\
\text { (mg/L) }\end{array}$ & $\begin{array}{l}\text { Fluo- } \\
\text { ride } \\
\text { (mg/L) }\end{array}$ & $\begin{array}{l}\text { Silica } \\
\text { (mg/L) }\end{array}$ & $\begin{array}{l}\text { Boron } \\
(\mu \mathrm{g} / \mathrm{L})\end{array}$ & $\begin{array}{c}\text { Iron } \\
(\mu \mathrm{g} / \mathrm{L})\end{array}$ \\
\hline \multicolumn{16}{|c|}{ Ground-water sites-Continued } \\
\hline 26 & 374101097191501 & 27S-01E-21DAC01 & $08 / 15 / 03$ & 1335 & 811 & 130 & 23 & 130 & 15 & 180 & 130 & 0.8 & 13 & 150 & E8 \\
\hline 27 & 374102097214301 & 27S-01E-19DBC01 & $08 / 15 / 03$ & 1430 & 776 & 120 & 19 & 130 & 3.4 & 120 & 130 & .6 & 18 & 120 & E4 \\
\hline 28 & 374310097193301 & 27S-01E-09ABC01 & 08/20/03 & 0915 & 723 & 140 & 36 & 68 & 13 & 110 & 47 & .5 & 20 & 280 & 11 \\
\hline 29 & 374419097254201 & 26S-01W-33DDD01 & $08 / 15 / 03$ & 0925 & 329 & 53 & 11 & 46 & 3.0 & 43 & 43 & .5 & 20 & 50 & $<8$ \\
\hline 30 & 374447097213701 & 26-01E-31ACC01 & $08 / 15 / 03$ & 1055 & 859 & 84 & 19 & 190 & 6.0 & 120 & 240 & .5 & 16 & 120 & 40 \\
\hline \multicolumn{16}{|c|}{ Surface-water sites } \\
\hline 31 & 07143375 & Arkansas River near Maize & $08 / 12 / 03$ & 0930 & 1,360 & 62 & 22 & 400 & 7.0 & 160 & 580 & 6 & 4.8 & 180 & $<24$ \\
\hline 32 & 07144550 & Arkansas River at Derby & $08 / 12 / 03$ & 1230 & 770 & 74 & 20 & 180 & 7.6 & 130 & 240 & .4 & 9.3 & 170 & E6 \\
\hline 33 & 07145500 & Ninnescah River near Peck & $08 / 12 / 03$ & 1400 & 726 & 52 & 18 & 200 & 4.2 & 64 & 280 & .4 & 7.2 & 110 & $<8$ \\
\hline 34 & 07146500 & Arkansas River at Arkansas City & $08 / 13 / 03$ & 1145 & 859 & 71 & 20 & 230 & 7.2 & 120 & 320 & .4 & 5.4 & 180 & 9 \\
\hline 35 & 371004097085700 & Slate Creek (33S-02E-24ADD) & $08 / 11 / 03$ & 1115 & 4,340 & 150 & 56 & 1,170 & 6.3 & 480 & 1,970 & .4 & 7.0 & 360 & $<24$ \\
\hline 36 & 371632097093600 & Arkansas River at Oxford & $08 / 11 / 03$ & 1040 & 898 & 84 & 22 & 230 & 7.5 & 130 & 300 & .5 & 9.4 & 180 & $<8$ \\
\hline 37 & 371758097083400 & Sand quarry near Oxford & 08/13/03 & 1200 & 318 & 48 & 13 & 38 & 3.3 & 64 & 46 & .3 & 6.7 & 60 & 11 \\
\hline 38 & 371852097104200 & Ninnescah River (31S-02E-35ABB) & $08 / 11 / 03$ & 1215 & 929 & 64 & 20 & 230 & 3.5 & 73 & 370 & .4 & 9.9 & 100 & $<8$ \\
\hline 39 & 372344097185400 & Oxbow lake near Belle Plaine & $08 / 19 / 03$ & 0850 & 3,730 & 110 & 73 & 310 & 12 & 120 & 1,990 & .3 & 16 & 260 & $<24$ \\
\hline 40 & 372828097160000 & Sand quarry near Mulvane & $08 / 13 / 03$ & 0920 & 368 & 58 & 16 & 46 & 3.6 & 98 & 41 & .5 & 2.5 & 90 & $<8$ \\
\hline
\end{tabular}


Table 12. Records of wells where water levels were measured during March 2001 and February 2002 in alluvial deposits in modeled area of Cowley, Sedgwick, and Sumner Counties, south-central Kansas.

[ft, feet; ft above NAVD 88, feet above North American Vertical Datum of 1988; --, not available or not measured]

\begin{tabular}{|c|c|c|c|c|c|c|}
\hline $\begin{array}{l}\text { Local well number } \\
\text { (township, range, } \\
\text { section, fig. 18) }\end{array}$ & Water use & $\begin{array}{c}\text { Depth of well } \\
(\mathrm{ft})\end{array}$ & $\begin{array}{c}\text { Land-surface } \\
\text { altitude } \\
\text { (ft above NAVD 88) }\end{array}$ & $\begin{array}{c}\text { Date of } \\
\text { measurement } \\
\text { (month/year) }\end{array}$ & $\begin{array}{l}\text { Depth to water } \\
(\mathrm{ft})\end{array}$ & $\begin{array}{l}\text { Ground-water level } \\
\text { (ft above NAVD 88) }\end{array}$ \\
\hline \multicolumn{7}{|c|}{ Cowley County } \\
\hline 31S-03E-20CCB & domestic & 37 & 1,189 & $\begin{array}{l}\text { Mar. } 2001 \\
\text { Feb. } 2002\end{array}$ & $\begin{array}{l}19.30 \\
26.70\end{array}$ & $\begin{array}{l}1,169.70 \\
1,162.30\end{array}$ \\
\hline $31 \mathrm{~S}-03 \mathrm{E}-28 \mathrm{BCC}$ & domestic & 36 & 1,222 & $\begin{array}{l}\text { Mar. } 2001 \\
\text { Feb. } 2002\end{array}$ & $\begin{array}{l}26.05 \\
26.65\end{array}$ & $\begin{array}{l}1,195.95 \\
1,195.35\end{array}$ \\
\hline $32 \mathrm{~S}-03 \mathrm{E}-06 \mathrm{ABB}$ & domestic & -- & 1,158 & $\begin{array}{l}\text { Mar. } 2001 \\
\text { Feb. } 2002\end{array}$ & $\begin{array}{l}11.65 \\
14.54\end{array}$ & $\begin{array}{l}1,146.35 \\
1,143.46\end{array}$ \\
\hline $32 \mathrm{~S}-03 \mathrm{E}-15 \mathrm{CBC}$ & industrial & 34 & 1,177 & $\begin{array}{l}\text { Mar. } 2001 \\
\text { Feb. } 2002\end{array}$ & $\begin{array}{r}6.11 \\
10.23\end{array}$ & $\begin{array}{l}1,170.89 \\
1,166.77\end{array}$ \\
\hline $32 \mathrm{~S}-03 \mathrm{E}-21 \mathrm{~B}$ & domestic & 38 & 1,177 & $\begin{array}{l}\text { Mar. } 2001 \\
\text { Feb. } 2002\end{array}$ & $\begin{array}{l}13.21 \\
17.50\end{array}$ & $\begin{array}{l}1,163.79 \\
1,159.50\end{array}$ \\
\hline $33 \mathrm{~S}-03 \mathrm{E}-03 \mathrm{ABB}$ & domestic & 30 & 1,160 & $\begin{array}{l}\text { Mar. } 2001 \\
\text { Feb. } 2002\end{array}$ & $\begin{array}{l}13.57 \\
14.93\end{array}$ & $\begin{array}{l}1,146.43 \\
1,145.07\end{array}$ \\
\hline 33S-03E-05BCB & irrigation & 40 & 1,125 & $\begin{array}{l}\text { Mar. } 2001 \\
\text { Feb. } 2002\end{array}$ & $\begin{array}{r}7.85 \\
10.57\end{array}$ & $\begin{array}{l}1,117.15 \\
1,114.43\end{array}$ \\
\hline 33S-03E-09BCC & domestic & 30 & 1,124 & $\begin{array}{l}\text { Mar. } 2001 \\
\text { Feb. } 2002\end{array}$ & $\begin{array}{l}13.00 \\
13.67\end{array}$ & $\begin{array}{l}1,111.00 \\
1,110.33\end{array}$ \\
\hline 33S-03E-14DDC & domestic & 49 & 1,164 & $\begin{array}{l}\text { Mar. } 2001 \\
\text { Feb. } 2002\end{array}$ & $\begin{array}{l}19.35 \\
23.04\end{array}$ & $\begin{array}{l}1,144.65 \\
1,140.96\end{array}$ \\
\hline 33S-03E-25CDD & irrigation & 47 & 1,164 & $\begin{array}{l}\text { Mar. } 2001 \\
\text { Feb. } 2002\end{array}$ & $\begin{array}{l}15.64 \\
21.35\end{array}$ & $\begin{array}{l}1,148.36 \\
1,142.65\end{array}$ \\
\hline 33S-03E-28DCB & irrigation & 39 & 1,111 & $\begin{array}{l}\text { Mar. } 2001 \\
\text { Feb. } 2002\end{array}$ & $\begin{array}{l}11.18 \\
13.45\end{array}$ & $\begin{array}{l}1,099.82 \\
1,097.55\end{array}$ \\
\hline 33S-03E-32BBB & irrigation & -- & 1,100 & $\begin{array}{l}\text { Mar. } 2001 \\
\text { Feb. } 2002\end{array}$ & $\begin{array}{r}8.14 \\
10.63\end{array}$ & $\begin{array}{l}1,091.86 \\
1,089.37\end{array}$ \\
\hline 34S-03E-04DAC & irrigation & -- & 1,101 & $\begin{array}{l}\text { Mar. } 2001 \\
\text { Feb. } 2002\end{array}$ & $\begin{array}{l}13.31 \\
14.98\end{array}$ & $\begin{array}{l}1,087.69 \\
1,086.02\end{array}$ \\
\hline 34S-03E-24CDC & $\begin{array}{l}\text { lawn and } \\
\text { garden }\end{array}$ & 44.5 & 1,115 & $\begin{array}{l}\text { Mar. } 2001 \\
\text { Feb. } 2002\end{array}$ & $\begin{array}{l}20.90 \\
23.20\end{array}$ & $\begin{array}{l}1,094.10 \\
1,091.80\end{array}$ \\
\hline \multicolumn{7}{|c|}{ Sedgwick County } \\
\hline $26 \mathrm{~S}-01 \mathrm{E}-21 \mathrm{BBB}$ & $\begin{array}{c}\text { lawn and } \\
\text { garden }\end{array}$ & 40 & 1,332 & $\begin{array}{l}\text { Mar. } 2001 \\
\text { Feb. } 2002\end{array}$ & $\begin{array}{l}2.99 \\
--\end{array}$ & $\begin{array}{c}1,329.01 \\
--\end{array}$ \\
\hline 26S-01E-31ADC & $\begin{array}{c}\text { lawn and } \\
\text { garden }\end{array}$ & 40 & 1,320 & $\begin{array}{l}\text { Mar. } 2001 \\
\text { Feb. } 2002\end{array}$ & $\begin{array}{l}17.21 \\
19.27\end{array}$ & $\begin{array}{l}1,302.79 \\
1,300.73\end{array}$ \\
\hline $26 \mathrm{~S}-01 \mathrm{~W}-33 \mathrm{DDD}$ & $\begin{array}{c}\text { lawn and } \\
\text { garden }\end{array}$ & 40 & 1,327 & $\begin{array}{l}\text { Mar. } 2001 \\
\text { Feb. } 2002\end{array}$ & $\begin{array}{l}5.89 \\
7.23\end{array}$ & $\begin{array}{l}1,321.11 \\
1,319.77\end{array}$ \\
\hline 27S-01E-08CCD & $\begin{array}{c}\text { lawn and } \\
\text { garden }\end{array}$ & 30 & 1,304 & $\begin{array}{l}\text { Mar. } 2001 \\
\text { Feb. } 2002\end{array}$ & $\begin{array}{l}13.40 \\
14.60\end{array}$ & $\begin{array}{l}1,290.60 \\
1,289.40\end{array}$ \\
\hline 27S-01E-09ABC & $\begin{array}{c}\text { lawn and } \\
\text { garden }\end{array}$ & 35 & 1,305 & $\begin{array}{l}\text { Mar. } 2001 \\
\text { Feb. } 2002\end{array}$ & $\begin{array}{l}12.11 \\
13.38\end{array}$ & $\begin{array}{l}1,292.89 \\
1,291.62\end{array}$ \\
\hline 27S-01E-19DBC & $\begin{array}{c}\text { lawn and } \\
\text { garden }\end{array}$ & 40 & 1,302 & $\begin{array}{l}\text { Mar. } 2001 \\
\text { Feb. } 2002\end{array}$ & $\begin{array}{l}14.07 \\
15.22\end{array}$ & $\begin{array}{l}1,287.93 \\
1,286.78\end{array}$ \\
\hline $27 \mathrm{~S}-01 \mathrm{E}-21 \mathrm{DAC}$ & $\begin{array}{c}\text { lawn and } \\
\text { garden }\end{array}$ & 30 & 1,295 & $\begin{array}{l}\text { Mar. } 2001 \\
\text { Feb. } 2002\end{array}$ & $\begin{array}{l}10.72 \\
11.67\end{array}$ & $\begin{array}{l}1,284.28 \\
1,283.33\end{array}$ \\
\hline
\end{tabular}


Table 12. Records of wells where water levels were measured during March 2001 and February 2002 in alluvial deposits in modeled area of Cowley, Sedgwick, and Sumner Counties, south-central Kansas. - Continued

[ft, feet; ft above NAVD 88, feet above North American Vertical Datum of 1988; --, not available or not measured]

\begin{tabular}{|c|c|c|c|c|c|c|}
\hline $\begin{array}{l}\text { Local well number } \\
\text { (township, range, } \\
\text { section, fig. 18) }\end{array}$ & Water use & $\begin{array}{l}\text { Depth of well } \\
\text { (ft) }\end{array}$ & $\begin{array}{c}\text { Land-surface } \\
\text { altitude } \\
\text { (ft above NAVD 88) }\end{array}$ & $\begin{array}{c}\text { Date of } \\
\text { measurement } \\
\text { (month/year) }\end{array}$ & $\begin{array}{l}\text { Depth to water } \\
\text { (ft) }\end{array}$ & $\begin{array}{l}\text { Ground-water level } \\
\text { (ft above NAVD 88) }\end{array}$ \\
\hline \multicolumn{7}{|c|}{ Sedgwick County-Continued } \\
\hline 27S-01W-08ACCC & $\begin{array}{l}\text { observation } \\
\text { well }\end{array}$ & -- & 1,345 & $\begin{array}{l}\text { Mar. } 2001 \\
\text { Feb. } 2002\end{array}$ & $\begin{array}{l}20.89 \\
23.60\end{array}$ & $\begin{array}{l}1,324.11 \\
1,321.40\end{array}$ \\
\hline $27 \mathrm{~S}-01 \mathrm{~W}-15 \mathrm{BBC}$ & $\begin{array}{c}\text { lawn and } \\
\text { garden }\end{array}$ & 55 & 1,336 & $\begin{array}{l}\text { Mar. } 2001 \\
\text { Feb. } 2002\end{array}$ & $\begin{array}{l}26.54 \\
28.34\end{array}$ & $\begin{array}{l}1,309.46 \\
1,307.66\end{array}$ \\
\hline $27 \mathrm{~S}-01 \mathrm{~W}-25 \mathrm{CBB}$ & $\begin{array}{l}\text { lawn and } \\
\text { garden }\end{array}$ & 51 & 1,305 & $\begin{array}{l}\text { Mar. } 2001 \\
\text { Feb. } 2002\end{array}$ & $\begin{array}{l}15.64 \\
16.96\end{array}$ & $\begin{array}{l}1,289.36 \\
1,288.04\end{array}$ \\
\hline 27S-01W-30AADA & $\begin{array}{l}\text { observation } \\
\text { well }\end{array}$ & -- & 1,330 & $\begin{array}{l}\text { Mar. } 2001 \\
\text { Feb. } 2002\end{array}$ & $\begin{array}{l}18.25 \\
23.18\end{array}$ & $\begin{array}{l}1,311.75 \\
1,306.82\end{array}$ \\
\hline $27 \mathrm{~S}-01 \mathrm{~W}-34 \mathrm{BBA}$ & $\begin{array}{c}\text { lawn and } \\
\text { garden }\end{array}$ & 65 & 1,317 & $\begin{array}{l}\text { Mar. } 2001 \\
\text { Feb. } 2002\end{array}$ & $\begin{array}{l}27.50 \\
30.30\end{array}$ & $\begin{array}{l}1,289.50 \\
1,286.70\end{array}$ \\
\hline 27S-02W-12CDDC & $\begin{array}{l}\text { observation } \\
\text { well }\end{array}$ & -- & 1,334 & $\begin{array}{l}\text { Mar. } 2001 \\
\text { Feb. } 2002\end{array}$ & $\begin{array}{l}10.18 \\
12.28\end{array}$ & $\begin{array}{l}1,323.82 \\
1,321.72\end{array}$ \\
\hline 27S-02W-24DADD & $\begin{array}{l}\text { observation } \\
\text { well }\end{array}$ & -- & 1,342 & $\begin{array}{l}\text { Mar. } 2001 \\
\text { Feb. } 2002\end{array}$ & $\begin{array}{l}26.87 \\
29.29\end{array}$ & $\begin{array}{l}1,315.13 \\
1,312.71\end{array}$ \\
\hline 28S-01E-05DBB & $\begin{array}{l}\text { observation } \\
\text { well }\end{array}$ & -- & 1,285 & $\begin{array}{l}\text { Mar. } 2001 \\
\text { Feb. } 2002\end{array}$ & $\begin{array}{l}14.46 \\
15.27\end{array}$ & $\begin{array}{l}1,270.54 \\
1,269.73\end{array}$ \\
\hline 28S-01E-16ADA & $\begin{array}{l}\text { observation } \\
\text { well }\end{array}$ & -- & 1,273 & $\begin{array}{l}\text { Mar. } 2001 \\
\text { Feb. } 2002\end{array}$ & $\begin{array}{l}7.17 \\
9.13\end{array}$ & $\begin{array}{l}1,265.83 \\
1,263.87\end{array}$ \\
\hline $28 \mathrm{~S}-01 \mathrm{E}-23 \mathrm{ABD}$ & $\begin{array}{c}\text { lawn and } \\
\text { garden }\end{array}$ & 65 & 1,288 & $\begin{array}{l}\text { Mar. } 2001 \\
\text { Feb. } 2002\end{array}$ & $\begin{array}{l}24.39 \\
--\end{array}$ & $\begin{array}{c}1,263.61 \\
--\end{array}$ \\
\hline 28S-01E-29CBB & $\begin{array}{l}\text { lawn and } \\
\text { garden }\end{array}$ & 49 & 1,266 & $\begin{array}{l}\text { Mar. } 2001 \\
\text { Feb. } 2002\end{array}$ & $\begin{array}{l}10.03 \\
11.74\end{array}$ & $\begin{array}{l}1,255.97 \\
1,254.26\end{array}$ \\
\hline 28S-01E-34BBBB & $\begin{array}{l}\text { observation } \\
\text { well }\end{array}$ & -- & 1,261 & $\begin{array}{l}\text { Mar. } 2001 \\
\text { Feb. } 2002\end{array}$ & $\begin{array}{r}8.57 \\
10.06\end{array}$ & $\begin{array}{l}1,252.43 \\
1,250.94\end{array}$ \\
\hline $28 \mathrm{~S}-01 \mathrm{~W}-05 \mathrm{BBB}$ & $\begin{array}{l}\text { observation } \\
\text { well }\end{array}$ & -- & 1,325 & $\begin{array}{l}\text { Mar. } 2001 \\
\text { Feb. } 2002\end{array}$ & $\begin{array}{l}17.05 \\
18.49\end{array}$ & $\begin{array}{l}1,307.95 \\
1,306.51\end{array}$ \\
\hline $28 \mathrm{~S}-01 \mathrm{~W}-10 \mathrm{DCC}$ & $\begin{array}{c}\text { lawn and } \\
\text { garden }\end{array}$ & 65 & 1,307 & $\begin{array}{l}\text { Mar. } 2001 \\
\text { Feb. } 2002\end{array}$ & $\begin{array}{l}34.26 \\
35.72\end{array}$ & $\begin{array}{l}1,272.74 \\
1,271.28\end{array}$ \\
\hline $28 \mathrm{~S}-01 \mathrm{~W}-11 \mathrm{CBB}$ & $\begin{array}{c}\text { lawn and } \\
\text { garden }\end{array}$ & 95 & 1,293 & $\begin{array}{l}\text { Mar. } 2001 \\
\text { Feb. } 2002\end{array}$ & $\begin{array}{l}21.05 \\
--\end{array}$ & $\begin{array}{c}1,271.95 \\
--\end{array}$ \\
\hline $28 \mathrm{~S}-01 \mathrm{~W}-23 \mathrm{BB}$ & $\begin{array}{c}\text { lawn and } \\
\text { garden }\end{array}$ & 110 & 1,294 & $\begin{array}{l}\text { Mar. } 2001 \\
\text { Feb. } 2002\end{array}$ & $\begin{array}{l}32.50 \\
33.76\end{array}$ & $\begin{array}{l}1,261.50 \\
1,260.24\end{array}$ \\
\hline $28 \mathrm{~S}-01 \mathrm{~W}-28 \mathrm{BBB}$ & irrigation & 127 & 1,316 & $\begin{array}{l}\text { Mar. } 2001 \\
\text { Feb. } 2002\end{array}$ & $\begin{array}{l}45.44 \\
46.38\end{array}$ & $\begin{array}{l}1,270.56 \\
1,269.62\end{array}$ \\
\hline $28 \mathrm{~S}-02 \mathrm{~W}-13 \mathrm{CCD}$ & $\begin{array}{c}\text { lawn and } \\
\text { garden }\end{array}$ & 65 & 1,345 & $\begin{array}{l}\text { Mar. } 2001 \\
\text { Feb. } 2002\end{array}$ & $\begin{array}{r}6.55 \\
11.05\end{array}$ & $\begin{array}{l}1,338.45 \\
1,333.95\end{array}$ \\
\hline $28 \mathrm{~S}-02 \mathrm{~W}-25 \mathrm{AAC}$ & irrigation & 138 & 1,345 & $\begin{array}{l}\text { Mar. } 2001 \\
\text { Feb. } 2002\end{array}$ & $\begin{array}{l}27.62 \\
30.94\end{array}$ & $\begin{array}{l}1,317.38 \\
1,314.06\end{array}$ \\
\hline 29S-01E-06BDC & $\begin{array}{c}\text { lawn and } \\
\text { garden }\end{array}$ & 45 & 1,294 & $\begin{array}{l}\text { Mar. } 2001 \\
\text { Feb. } 2002\end{array}$ & $\begin{array}{l}35.47 \\
36.51\end{array}$ & $\begin{array}{l}1,258.53 \\
1,257.49\end{array}$ \\
\hline 29S-01E-09BC & $\begin{array}{l}\text { observation } \\
\text { well }\end{array}$ & -- & 1,255 & $\begin{array}{l}\text { Mar. } 2001 \\
\text { Feb. } 2002\end{array}$ & $\begin{array}{l}10.07 \\
12.66\end{array}$ & $\begin{array}{l}1,244.93 \\
1,242.34\end{array}$ \\
\hline
\end{tabular}


Table 12. Records of wells where water levels were measured during March 2001 and February 2002 in alluvial deposits in modeled area of Cowley, Sedgwick, and Sumner Counties, south-central Kansas.-Continued

[ft, feet; ft above NAVD 88, feet above North American Vertical Datum of 1988; --, not available or not measured]

\begin{tabular}{|c|c|c|c|c|c|c|}
\hline $\begin{array}{l}\text { Local well number } \\
\text { (township, range, } \\
\text { section, fig. 18) }\end{array}$ & Water use & $\begin{array}{l}\text { Depth of well } \\
\qquad(\mathrm{ft})\end{array}$ & $\begin{array}{c}\text { Land-surface } \\
\text { altitude } \\
\text { (ft above NAVD 88) }\end{array}$ & $\begin{array}{c}\text { Date of } \\
\text { measurement } \\
\text { (month/year) }\end{array}$ & $\begin{array}{l}\text { Depth to water } \\
\text { (ft) }\end{array}$ & $\begin{array}{l}\text { Ground-water level } \\
\text { (ft above NAVD 88) }\end{array}$ \\
\hline \multicolumn{7}{|c|}{ Sedgwick County-Continued } \\
\hline 29S-01E-14DCC & $\begin{array}{l}\text { public } \\
\text { supply }\end{array}$ & 37.5 & 1,240 & $\begin{array}{l}\text { Mar. } 2001 \\
\text { Feb. } 2002\end{array}$ & $\begin{array}{l}18.50 \\
19.60\end{array}$ & $\begin{array}{l}1,221.50 \\
1,220.40\end{array}$ \\
\hline 29S-01E-19DDC & $\begin{array}{c}\text { lawn and } \\
\text { garden }\end{array}$ & 60 & 1,276 & $\begin{array}{l}\text { Mar. } 2001 \\
\text { Feb. } 2002\end{array}$ & $\begin{array}{l}33.75 \\
33.69\end{array}$ & $\begin{array}{l}1,242.25 \\
1,242.31\end{array}$ \\
\hline 29S-01E-34DBC & irrigation & 54 & 1,232 & $\begin{array}{l}\text { Mar. } 2001 \\
\text { Feb. } 2002\end{array}$ & $\begin{array}{r}9.07 \\
11.63\end{array}$ & $\begin{array}{l}1,222.93 \\
1,220.37\end{array}$ \\
\hline 29S-01E-36CCC & $\begin{array}{l}\text { public } \\
\text { supply }\end{array}$ & 53 & 1,225 & $\begin{array}{l}\text { Mar. } 2001 \\
\text { Feb. } 2002\end{array}$ & $\begin{array}{l}12.80 \\
16.12\end{array}$ & $\begin{array}{l}1,212.20 \\
1,208.88\end{array}$ \\
\hline $29 \mathrm{~S}-01 \mathrm{~W}-04 \mathrm{DCA}$ & $\begin{array}{c}\text { lawn and } \\
\text { garden }\end{array}$ & 90 & 1,297 & $\begin{array}{l}\text { Mar. } 2001 \\
\text { Feb. } 2002\end{array}$ & $\begin{array}{l}21.28 \\
21.26\end{array}$ & $\begin{array}{l}1,275.72 \\
1,275.74\end{array}$ \\
\hline $29 \mathrm{~S}-01 \mathrm{~W}-21 \mathrm{CCD}$ & $\begin{array}{c}\text { lawn and } \\
\text { garden }\end{array}$ & 55 & 1,270 & $\begin{array}{l}\text { Mar. } 2001 \\
\text { Feb. } 2002\end{array}$ & $\begin{array}{l}19.93 \\
24.82\end{array}$ & $\begin{array}{l}1,250.07 \\
1,245.18\end{array}$ \\
\hline $29 \mathrm{~S}-01 \mathrm{~W}-25 \mathrm{D}$ & irrigation & 65 & 1,274 & $\begin{array}{l}\text { Mar. } 2001 \\
\text { Feb. } 2002\end{array}$ & $\begin{array}{l}33.34 \\
34.49\end{array}$ & $\begin{array}{l}1,240.66 \\
1,239.51\end{array}$ \\
\hline $29 \mathrm{~S}-01 \mathrm{~W}-29 \mathrm{BAC}$ & $\begin{array}{l}\text { lawn and } \\
\text { garden }\end{array}$ & 65 & 1,271 & $\begin{array}{l}\text { Mar. } 2001 \\
\text { Feb. } 2002\end{array}$ & $\begin{array}{l}18.40 \\
24.19\end{array}$ & $\begin{array}{l}1,252.60 \\
1,246.81\end{array}$ \\
\hline \multicolumn{7}{|c|}{ Sumner County } \\
\hline 30S-01E-5BDD & irrigation & 55 & 1,260 & $\begin{array}{l}\text { Mar. } 2001 \\
\text { Feb. } 2002\end{array}$ & $\begin{array}{l}25.36 \\
--\end{array}$ & $\begin{array}{c}1,234.64 \\
--\end{array}$ \\
\hline 30S-01E-09BCA & irrigation & 48 & 1,246 & $\begin{array}{l}\text { Mar. } 2001 \\
\text { Feb. } 2002\end{array}$ & $\begin{array}{l}13.56 \\
14.70\end{array}$ & $\begin{array}{l}1,232.44 \\
1,231.30\end{array}$ \\
\hline 30S-01E-14DAB & domestic & 20 & 1,214 & $\begin{array}{l}\text { Mar. } 2001 \\
\text { Feb. } 2002\end{array}$ & $\begin{array}{l}3.93 \\
6.58\end{array}$ & $\begin{array}{l}1,210.07 \\
1,207.42\end{array}$ \\
\hline 30S-01E-22CCC & $\begin{array}{c}\text { lawn and } \\
\text { garden }\end{array}$ & 35 & 1,231 & $\begin{array}{l}\text { Mar. } 2001 \\
\text { Feb. } 2002\end{array}$ & $\begin{array}{l}15.30 \\
17.85\end{array}$ & $\begin{array}{l}1,215.70 \\
1,213.15\end{array}$ \\
\hline 30S-01E-29DCD & domestic & 47 & 1,212 & $\begin{array}{l}\text { Mar. } 2001 \\
\text { Feb. } 2002\end{array}$ & $\begin{array}{l}21.64 \\
23.74\end{array}$ & $\begin{array}{l}1,190.36 \\
1,188.26\end{array}$ \\
\hline 30S-01E-36CDD & $\begin{array}{c}\text { lawn and } \\
\text { garden }\end{array}$ & 40 & 1,210 & $\begin{array}{l}\text { Mar. } 2001 \\
\text { Feb. } 2002\end{array}$ & $\begin{array}{l}12.72 \\
14.76\end{array}$ & $\begin{array}{l}1,197.28 \\
1,195.24\end{array}$ \\
\hline $30 \mathrm{~S}-02 \mathrm{E}-18 \mathrm{~B}$ & irrigation & 55 & 1,213 & $\begin{array}{l}\text { Mar. } 2001 \\
\text { Feb. } 2002\end{array}$ & $\begin{array}{r}7.81 \\
10.09\end{array}$ & $\begin{array}{l}1,205.19 \\
1,202.91\end{array}$ \\
\hline 30S-02E-34DAA & domestic & 50 & 1,215 & $\begin{array}{l}\text { Mar. } 2001 \\
\text { Feb. } 2002\end{array}$ & $\begin{array}{l}24.93 \\
25.92\end{array}$ & $\begin{array}{l}1,190.07 \\
1,189.08\end{array}$ \\
\hline $30 \mathrm{~S}-01 \mathrm{~W}-01 \mathrm{CCB}$ & domestic & 31 & 1,237 & $\begin{array}{l}\text { Mar. } 2001 \\
\text { Feb. } 2002\end{array}$ & $\begin{array}{l}11.92 \\
14.95\end{array}$ & $\begin{array}{l}1,225.08 \\
1,222.05\end{array}$ \\
\hline 31S-01E-13ABD & irrigation & 37 & 1,188 & $\begin{array}{l}\text { Mar. } 2001 \\
\text { Feb. } 2002\end{array}$ & $\begin{array}{l}10.75 \\
11.17\end{array}$ & $\begin{array}{l}1,177.25 \\
1,176.83\end{array}$ \\
\hline 31S-02E--05DDC & irrigation & 50 & 1,190 & $\begin{array}{l}\text { Mar. } 2001 \\
\text { Feb. } 2002\end{array}$ & $\begin{array}{r}7.44 \\
10.67\end{array}$ & $\begin{array}{l}1,182.56 \\
1,179.33\end{array}$ \\
\hline 31S-02E-09B & irrigation & 66 & 1,186 & $\begin{array}{l}\text { Mar. } 2001 \\
\text { Feb. } 2002\end{array}$ & $\begin{array}{l}10.59 \\
13.53\end{array}$ & $\begin{array}{l}1,175.41 \\
1,172.47\end{array}$ \\
\hline 31S-02E-12AAC & -- & -- & 1,202 & $\begin{array}{l}\text { Mar. } 2001 \\
\text { Feb. } 2002\end{array}$ & $\begin{array}{l}28.27 \\
29.19\end{array}$ & $\begin{array}{l}1,173.73 \\
1,172.81\end{array}$ \\
\hline
\end{tabular}


Table 12. Records of wells where water levels were measured during March 2001 and February 2002 in alluvial deposits in modeled area of Cowley, Sedgwick, and Sumner Counties, south-central Kansas. - Continued

[ft, feet; ft above NAVD 88, feet above North American Vertical Datum of 1988; --, not available or not measured]

\begin{tabular}{|c|c|c|c|c|c|c|}
\hline $\begin{array}{l}\text { Local well number } \\
\text { (township, range, } \\
\text { section, fig. 18) }\end{array}$ & Water use & $\begin{array}{l}\text { Depth of well } \\
\text { ( } \mathrm{ft})\end{array}$ & $\begin{array}{c}\text { Land-surface } \\
\text { altitude } \\
\text { (ft above NAVD 88) }\end{array}$ & $\begin{array}{c}\text { Date of } \\
\text { measurement } \\
\text { (month/year) }\end{array}$ & $\begin{array}{l}\text { Depth to water } \\
\text { (ft) }\end{array}$ & $\begin{array}{l}\text { Ground-water level } \\
\text { (ft above NAVD 88) }\end{array}$ \\
\hline \multicolumn{7}{|c|}{ Sumner County-Continued } \\
\hline $31 \mathrm{~S}-02 \mathrm{E}-20 \mathrm{ABB}$ & domestic & 54 & 1,183 & $\begin{array}{l}\text { Mar. } 2001 \\
\text { Feb. } 2002\end{array}$ & $\begin{array}{l}14.73 \\
20.11\end{array}$ & $\begin{array}{l}1,168.27 \\
1,162.89\end{array}$ \\
\hline 31S-02E-21DDD & -- & -- & 1,174 & $\begin{array}{l}\text { Mar. } 2001 \\
\text { Feb. } 2002\end{array}$ & $\begin{array}{l}11.25 \\
14.65\end{array}$ & $\begin{array}{l}1,162.75 \\
1,159.35\end{array}$ \\
\hline $31 \mathrm{~S}-02 \mathrm{E}-23 \mathrm{~B}$ & -- & 60 & 1,169 & $\begin{array}{l}\text { Mar. } 2001 \\
\text { Feb. } 2002\end{array}$ & $\begin{array}{r}7.56 \\
10.74\end{array}$ & $\begin{array}{l}1,161.44 \\
1,158.26\end{array}$ \\
\hline $32 \mathrm{~S}-02 \mathrm{E}-13 \mathrm{ABA}$ & $\begin{array}{l}\text { lawn and } \\
\text { garden }\end{array}$ & 30 & 1,150 & $\begin{array}{l}\text { Mar. } 2001 \\
\text { Feb. } 2002\end{array}$ & $\begin{array}{r}8.83 \\
11.75\end{array}$ & $\begin{array}{l}1,141.17 \\
1,138.25\end{array}$ \\
\hline 32S-02E-25DC & -- & -- & 1,141 & $\begin{array}{l}\text { Mar. } 2001 \\
\text { Feb. } 2002\end{array}$ & $\begin{array}{l}16.07 \\
19.76\end{array}$ & $\begin{array}{l}1,124.93 \\
1,121.24\end{array}$ \\
\hline
\end{tabular}


Table 13. Results of miscellaneous streamflow measurements made in March 2001, February 2002, and August 2003 in modeled area of lower Arkansas River Basin, south-central Kansas.

$\left[\mathrm{ft}^{3} / \mathrm{s}\right.$, cubic feet per second; --, not measured]

\begin{tabular}{|c|c|c|c|c|}
\hline $\begin{array}{l}\text { Map number } \\
\text { (fig. 8) }\end{array}$ & Site identification number & Site name & $\begin{array}{c}\text { Date of } \\
\text { measurement } \\
\text { (month/year) }\end{array}$ & $\begin{array}{c}\text { Streamflow } \\
\text { discharge } \\
\left(\mathrm{ft}^{3} / \mathrm{s}\right)\end{array}$ \\
\hline 1 & 371004097085700 & Slate Creek, Kansas, 33S-02E-24AAD & $\begin{array}{l}\text { Mar. } 2001 \\
\text { Feb. } 2002 \\
\text { Aug. } 2003\end{array}$ & $\begin{array}{r}49.6 \\
10.9 \\
2.0\end{array}$ \\
\hline 2 & 370844097070600 & $\begin{array}{l}\text { Arkansas River near Rainbow Bend, Kansas } \\
\text { 33S-03E-29DCA-01 }\end{array}$ & $\begin{array}{l}\text { Mar. } 2001 \\
\text { Feb. } 2002\end{array}$ & $\begin{array}{r}2,450 \\
574\end{array}$ \\
\hline 3 & 371632097093600 & Arkansas River at Oxford, Kansas & $\begin{array}{l}\text { Mar. } 2001 \\
\text { Feb. } 2002\end{array}$ & $\begin{array}{r}2,500 \\
557\end{array}$ \\
\hline 4 & 371852097104200 & Ninnescah River, Kansas, 31S-02E-35ABB & $\begin{array}{l}\text { Mar. } 2001 \\
\text { Feb. } 2002\end{array}$ & $\begin{array}{r}1,470 \\
2.41\end{array}$ \\
\hline 5 & 07143375 & Arkansas River near Maize, Kansas & $\begin{array}{l}\text { Mar. } 2001 \\
\text { Feb. } 2002 \\
\text { Aug. } 2003\end{array}$ & $\begin{array}{c}672 \\
153 \\
51.2\end{array}$ \\
\hline 6 & 07144200 & Little Arkansas River at Valley Center, Kansas & $\begin{array}{l}\text { Mar. } 2001 \\
\text { Feb. } 2002\end{array}$ & $\begin{array}{r}107 \\
53\end{array}$ \\
\hline 7 & 07144300 & Arkansas River at Wichita, Kansas & $\begin{array}{l}\text { Mar. } 2001 \\
\text { Feb. } 2002\end{array}$ & $\begin{array}{l}888 \\
219\end{array}$ \\
\hline 8 & 07144480 & $\begin{array}{l}\text { Cowskin Creek at 119th Street, Wichita, } \\
\text { Kansas }\end{array}$ & $\begin{array}{l}\text { Mar. } 2001 \\
\text { Feb. } 2002\end{array}$ & -- \\
\hline 9 & 07144545 & Cowskin Creek near Oatville, Kansas & $\begin{array}{l}\text { Mar. } 2001 \\
\text { Feb. } 2002\end{array}$ & -- \\
\hline 10 & 07144550 & Arkansas River at Derby, Kansas & $\begin{array}{l}\text { Mar. } 2001 \\
\text { Feb. } 2002 \\
\text { Aug. } 2003\end{array}$ & $\begin{array}{l}938 \\
255 \\
167\end{array}$ \\
\hline 11 & 07145500 & Ninnescah River near Peck, Kansas & $\begin{array}{l}\text { Mar. } 2001 \\
\text { Feb. } 2002 \\
\text { Aug. } 2003\end{array}$ & $\begin{array}{l}357 \\
221 \\
45.1\end{array}$ \\
\hline 12 & 07145700 & Slate Creek near Wellington, Kansas & $\begin{array}{l}\text { Mar. } 2001 \\
\text { Feb. } 2002\end{array}$ & $\begin{array}{l}5.5 \\
7.1\end{array}$ \\
\hline 13 & 07146500 & Arkansas River near Arkansas City, Kansas & $\begin{array}{l}\text { Mar. } 2001 \\
\text { Feb. } 2002 \\
\text { Aug. } 2003\end{array}$ & $\begin{array}{r}1,340 \\
616 \\
386\end{array}$ \\
\hline 14 & 07147800 & Walnut River at Winfield, Kansas & $\begin{array}{l}\text { Mar. } 2001 \\
\text { Feb. } 2002\end{array}$ & $\begin{array}{l}452 \\
77.2\end{array}$ \\
\hline 15 & 07147900 & Walnut River at Arkansas City, Kansas & $\begin{array}{l}\text { Mar. } 2001 \\
\text { Feb. } 2002\end{array}$ & 88.5 \\
\hline 16 & 372225097121800 & $\begin{array}{l}\text { Cowskin Creek near Arkansas River, Kansas, } \\
\text { 31S-02E-09AAA }\end{array}$ & $\begin{array}{l}\text { Mar. } 2001 \\
\text { Feb. } 2002\end{array}$ & $-\overline{2.36}$ \\
\hline
\end{tabular}

